\title{
Effects of Temperature and Contamination on MPCMS Electrodes in 241-AY-101 and 241-AN-107 Tank Waste Simulants
}

\author{
M. M. Dahl, S. L. Philo, G. L. Edgemon, Dr. J. L. S. Bell, C. G. Moore
}

ARES Corporation for Washington River Protection Solutions, LLC

Richland, WA 99352

U.S. Department of Energy Contract DE-AC27-08RV14800

$\begin{array}{llll}\text { EDT/ECN: } & \text { DRF } & & \text { UC: } \\ \text { Cost Center: } & & & \text { Charge Code: } \\ \text { B\&R Code: } & & & \text { Total Pages: } \quad 192 \underset{3-26-10}{N-F}-10\end{array}$

Key Words: DSTIP, electrode durability, electrode contamination, MPCMS, corrosion, multi-probe corrosion monitoring system, 241-AN-107, 241-AN-102, 241-AY-101, and 241-AY-102.

Abstract: This report documents the results of tests designed to characterize the relationship between temperature and the measured potential of electrodes installed on multi-probe corrosion monitoring systems in waste tanks. This report also documents the results of tests designed to demonstrate the impact of liquid in-leakage into electrode bodies as well as the contamination of primary reference electrodes by diffusion through the electrode tip.

TRADEMARK DISCLAIMER. Reference herein to any specific commercial product, process, or service by trade name, trademark, manufacturer, or otherwise, does not necessarily constitute or imply its endorsement, recommendation, or favoring by the United States Govemment or any agency thereof or its contractors or subcontractors.

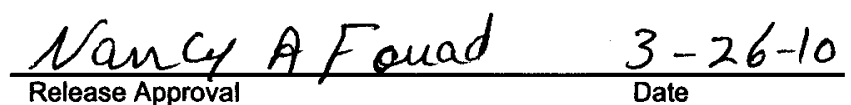

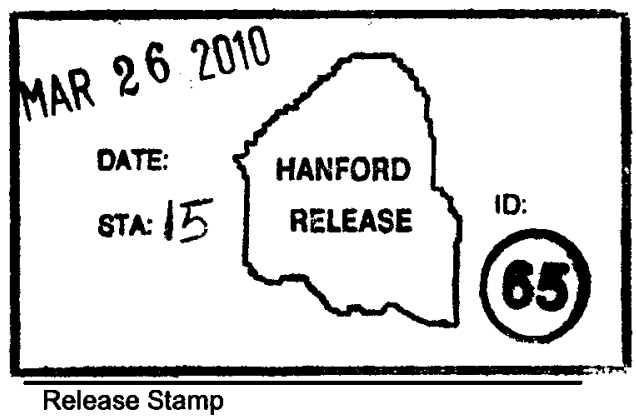




\title{
EFFECTS OF TEMPERATURE AND CONTAMINATION ON MPCMS ELECTRODES
} IN 241-AY-101 AND 241-AN-107 TANK WASTE SIMULANTS

\author{
March 2010
}

prepared by

\author{
ARES Corporation \\ 1100 Jadwin Avenue, Suite 400 \\ Richland, Washington 99352 \\ (509) 946-3300
}

prepared for

Washington River Protection Solutions, LLC 


\section{EXECUTIVE SUMMARY}

In 2007, the design requirements for a new Multi-Probe Corrosion Monitoring System were developed by the Hanford Tank Farm Contractor and issued in RPP-SPEC-32496, Procurement Specification for AN-102 Corrosion Probe Assembly. Based on these requirements and lessons learned from previous double-shell tank corrosion monitoring systems, a system was designed, fabricated, and installed in Double-shell Tank 241-AN-102 on May 1, 2008. A similar system was designed, fabricated, and installed in Double-shell Tank 241-AY-102 on March 26, 2009. In general, these systems collect corrosion potential and corrosion rate data from a variety of electrodes installed on an in-tank probe ${ }^{1}$.

Corrosion potentials of the tank and tank material electrodes relative to the primary reference electrodes have varied with temperature since the Multi-Probe Corrosion Monitoring System was installed in Tank 241-AN-102. However, the shift has not been consistent with that predicted by the temperature coefficients for the primary reference electrodes. In addition, a variety of electrode failures are suspected on the 241-AY-102 Multi-Probe Corrosion Monitoring System. None of these issues were expected prior to installation. Laboratory testing was performed to better characterize both the shift in potential with temperature in the field data and the suspected electrode failures.

Temperature testing was performed to determine the effect of temperature changes on the potentials of Multi-Probe Corrosion Monitoring System primary reference electrodes and tank steel electrodes. Testing indicated that a relatively direct relationship exists between temperature changes and the corrosion potentials of Multi-Probe Corrosion Monitoring System-style primary reference electrodes. No significant shifts in the potentials of the steel electrodes were observed over the temperature range investigated by the laboratory work.

Similar variations of potential with temperature were seen in the laboratory test data for the primary reference electrodes as are seen in the field data. However, neither field nor laboratory test results produce the expected shift in potential with temperature predicted by electrode temperature coefficients. Because results from laboratory and field are similar, there is no reason to expect malfunction of the primary reference electrodes on the 241-AN-102 Multi-Probe Corrosion Monitoring System, or to assume that the shift in potential with temperature is affected by the radiation field in the tank. The unpredicted response to temperature may simply be related to the design of the specialized electrodes used on the Multi-Probe Corrosion Monitoring Systems.

The suspected failures of certain electrodes on the 241-AY-102 Multi-Probe Corrosion Monitoring System appear to be related to the presence of an unknown liquid within the in-tank probe body. To explore this failure mode, liquid in-leakage testing was performed to better understand the effects of the formation of an electrical short within the probe body due to the presence of an intruding liquid. Laboratory testing showed that shifts in potential induced by wetting the backs of primary and secondary reference electrodes generally correlated to the conductivity of the wetting liquid. The influence of the three most likely liquids present in the

\footnotetext{
${ }^{1}$ In addition, corrosion monitoring systems similar in design to the 241-AN-102 and 241-AY-102 MPCMS have been installed or are planned for installation in 241-AY-101,241-AN-107, and 241-AW-104.
} 
probe body (water, un-reacted foam component liquid, and tank waste) was evaluated. The shifts in potential induced by wetting the backs of primary and secondary reference electrodes with 241-AY-101 tank waste simulant are different in direction, but similar in magnitude to the shifts in potential observed on suspected failed electrodes on the 241-AY-102 corrosion monitoring system. This similarity in magnitude suggests that tank waste may have intruded into the 241-AY-102 Multi-Probe Corrosion Monitoring System in-tank probe body.

Because it is known that the filling solutions of primary reference electrodes become contaminated over time with the environment in which they are immersed, primary reference electrode electrolyte contamination tests were performed to characterize the change in electrode potential associated with the progressive contamination of the Multi-Probe Corrosion Monitoring System-style primary reference electrodes. Surprisingly, test results indicated little sensitivity of the electrode potential to contamination by the tank waste simulants. 


\section{TABLE OF CONTENTS}

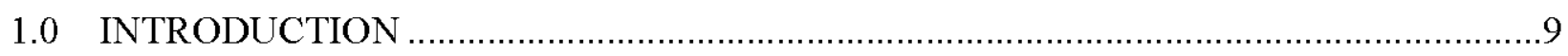

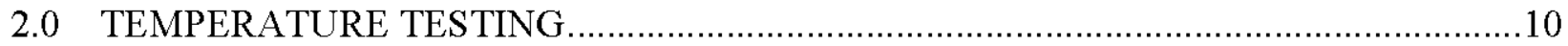

$2.1 \quad$ Background and Purpose …........................................................................... 10

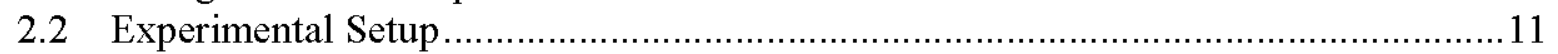

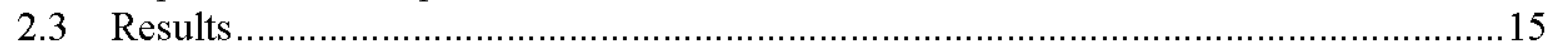

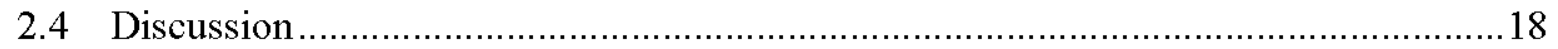

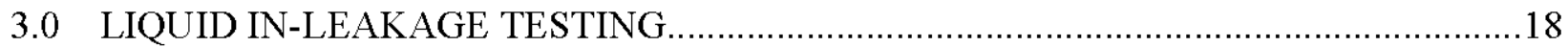

3.1 Background and Purpose …......................................................................... 18

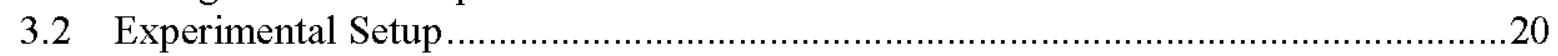

3.3 Tank Material and Secondary Reference Electrode Results ..................................24

3.4 Tank Material and Secondary Reference Electrode Discussion .............................29

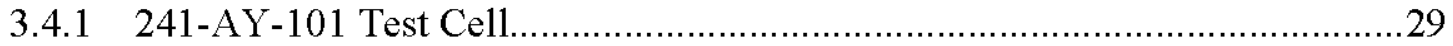

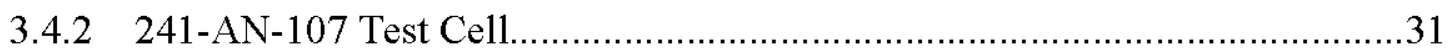

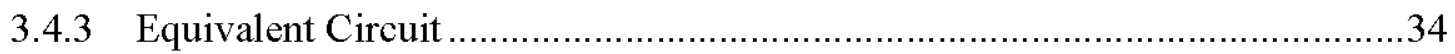

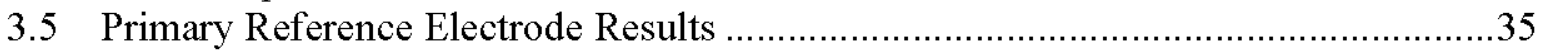

3.6 Primary Reference Electrode Discussion..............................................................39

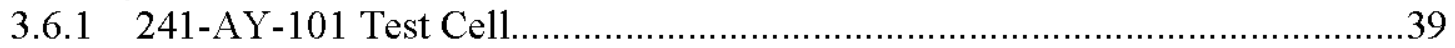

3.6.2 241-AN-107 Test Cell........................................................................ 40

3.6.3 Equivalent Circuit ........................................................................ 41

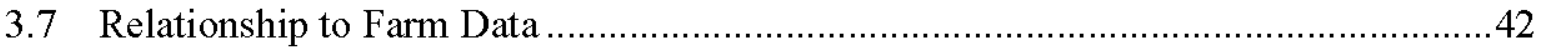

4.0 ELECTRODE ELECTROLYTE CONTAMINATION .............................................44

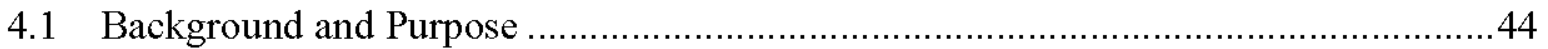

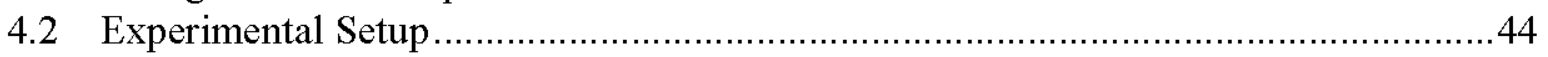

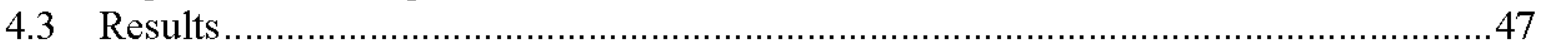

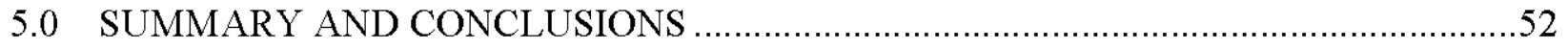

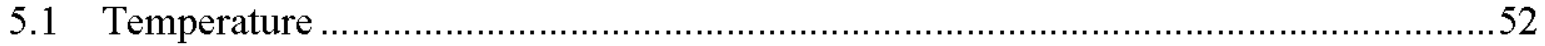

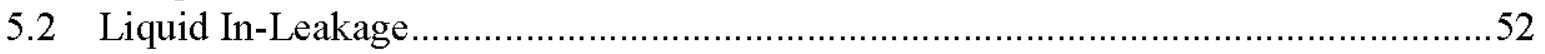

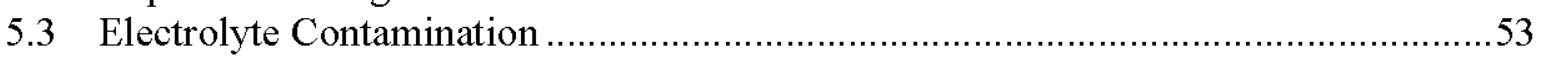

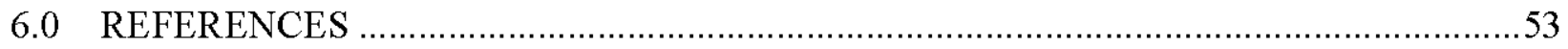

\section{LIST OF APPENDICES}

Appendix A - Waste Simulant Compositions

Appendix B - Calibration Data

Appendix C - Data Sheets

Appendix D - Test Exceptions

Appendix E - Supplementary Data 
RPP-RPT-44463, Rev. 0

\section{LIST OF FIGURES}

Figure 2-1. General Experimental Setup (Salt Bridges Highlighted for Clarity).....................12

Figure 2-2. Temperature Test Apparatus. ......................................................................... 13

Figure 2-3. Potential of MPCMS-Style Primary Reference Electrodes Under Test in 241-AY-101 Waste Simulant at Various Temperatures with Respect to MPCMS-Style Primary Reference Electrodes Held at $25^{\circ} \mathrm{C}$.

Figure 2-4. Potential of MPCMS-Style Primary Reference Electrodes Under Test in 241-AN-107 Waste Simulant at Various Temperatures with Respect to MPCMS-Style Primary Reference Electrodes Held at $25^{\circ} \mathrm{C}$.

Figure 2-5. Potential of AAR TC128 Steel Electrode Under Test in 241-AY-101

Waste Simulant at Various Temperatures with Respect to MPCMS-Style Primary Reference Electrodes Held at $25^{\circ} \mathrm{C}$.

Figure 2-6. Potential of ASTM A537 CL1 Steel Electrode Under Test in 241-AN-107 Waste Simulant at Various Temperatures with Respect to MPCMS-Style Primary Reference Electrodes Held at $25^{\circ} \mathrm{C}$.

Figure 3-1. Liquid In-Leakage Test Apparatus (Salt Bridges Not Shown). .21

Figure 3-2. 241-AY-101 Nickel Electrode Wetting. Potential of the Nickel Secondary Reference Electrode is Measured with Respect to the Reference MPCMS-Style Primary Reference Electrodes at Room Temperature in 241AY-101 Waste Simulant. Groups Represent Individual Contamination Steps.

Figure 3-3. 241-AN-107 Nickel Electrode Wetting. Potential of the Nickel

Secondary Reference Electrode is Measured with Respect to the Reference MPCMS-Style Primary Reference Electrodes at Room Temperature in 241AN-107 Waste Simulant. Groups Represent Individual Contamination Steps.

Figure 3-4. 241-AY-101 Copper Electrode Wetting. Potential of the Copper Secondary Reference Electrode is Measured with Respect to the Reference MPCMS-Style Primary Reference Electrodes at Room Temperature in 241AY-101 Waste Simulant. Groups Represent Individual Contamination Steps.

Figure 3-5. 241-AN-107 Copper Electrode Wetting. Potential of the Copper Secondary Reference Electrode is Measured with Respect to the Reference MPCMS-Style Primary Reference Electrodes at Room Temperature in 241AN-107 Waste Simulant. Groups Represent Individual Contamination Steps.

Figure 3-6. 241-AY-101 Silver Electrode Wetting. Potential of the Silver Secondary Reference Electrode is Measured with Respect to the Reference MPCMSStyle Primary Reference Electrodes at Room Temperature in 241-AY-101 Waste Simulant. Groups Represent Individual Contamination Steps.

Figure 3-7. 241-AN-107 Silver Electrode Wetting. Potential of the Silver Secondary Reference Electrode is Measured with Respect to the Reference MPCMSStyle Primary Reference Electrodes at Room Temperature in 241-AN-107 Waste Simulant. Groups Represent Individual Contamination Steps. 
Figure 3-8. 241-AY-101 Tank Material Electrode Wetting. Potential of the AAR TC128 Secondary Reference Electrode is Measured with Respect to the Reference MPCMS-Style Primary Reference Electrodes at Room Temperature in 241-AY-101 Waste Simulant. Groups Represent Individual Contamination Steps.

Figure 3-9. 241-AN-107 Tank Material Electrode Wetting. Potential of the ASTM A537 CL1 Secondary Reference Electrode is Measured with Respect to the reference MPCMS-Style Primary Reference Electrodes at Room Temperature in 241-AN-107 Waste Simulant. Groups Represent Individual Contamination Steps.

Figure 3-10. Electrical Schematic of a Secondary Reference Electrode in an In-Tank Probe with Waste In-Leakage.

Figure 3-11. Measured Potential of the $\mathrm{Ag} / \mathrm{AgCl}$ Electrode with Respect to the Reference MPCMS-Style Primary Reference Electrodes at Room Temperature in 241-AY-101 Waste Simulant. Groups Represent Individual Contamination Steps.

Figure 3-12. Measured Potential of the $\mathrm{Ag} / \mathrm{AgCl}$ Electrode with Respect To the Reference MPCMS-Style Primary Reference Electrodes at Room Temperature in 241-AN-107 Waste Simulant. Groups Represent Individual Contamination Steps.

Figure 3-13. Measured Potential of the Calomel Electrode with Respect to the Reference MPCMS-Style Primary Reference Electrodes at Room Temperature in 241-AY-101 Waste Simulant. Groups Represent Individual Contamination Steps.

Figure 3-14. Measured Potential of the Calomel Electrode with Respect to the Reference MPCMS-Style Primary Reference Electrodes at Room Temperature in 241-AN-107 Waste Simulant. Groups Represent Individual Contamination Steps.

Figure 3-15. Measured Potential of the $\mathrm{Cu} / \mathrm{CuSO}_{4}$ Electrode with Respect to the Reference MPCMS-Style Primary Reference Electrodes at Room Temperature in 241-AY-101 Waste Simulant. Groups Represent Individual Contamination Steps.

Figure 3-16. Measured Potential of the $\mathrm{Cu} / \mathrm{CuSO}_{4}$ Electrode with Respect to the Reference MPCMS-Style Primary Reference Electrodes at Room Temperature in 241-AN-107 Waste Simulant. Groups Represent Individual Contamination Steps.

Figure 3-17. Electrical Schematic of a Primary Reference Electrode in an In-Tank Probe with Waste In-Leakage.

Figure 4-1. Electrode Electrolyte Contamination Test Setup.

Figure 4-2. Measured Potentials of the MPCMS Primary Reference Electrodes Under Test with Respect to the Corresponding $25^{\circ} \mathrm{C}$ Electrodes and Measured 
Potentials of the Tank Material Electrodes Measured with Respect to the MCPMS Electrodes Under Test in 241-AY-101 Waste Simulant.

Figure 4-3. Measured Potentials of the MPCMS Primary Reference Electrodes Under

Test with Respect to the Corresponding $25^{\circ} \mathrm{C}$ Electrodes and Measured

Potentials of the Tank Material Electrodes Measured with Respect to the

MCPMS Electrodes Under Test in 241-AN-107 Waste Simulant.

\section{LIST OF TABLES}

Table 1-1. Reference Electrodes Used in Testing........................................................ 10

Table 2-1. Standard Reference Electrode Temperature Coefficients.' ....................................11

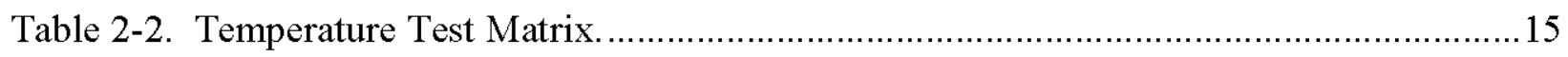

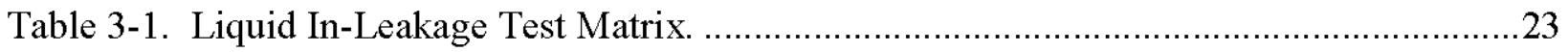

Table 3-2. Potential Difference Measured for the Secondary Reference Electrodes with Respect to Each Reference MPCMS Primary Reference Electrode Held at $25^{\circ} \mathrm{C}$ in the 241-AY-101 Test Cell.

Table 3-3. Potential Difference Measured for the Secondary Reference Electrodes with Respect to Each Reference MPCMS Primary Reference Electrode Held at $25^{\circ} \mathrm{C}$ in the $241-\mathrm{AN}-107$ Test Cell.

Table 3-4. Potential Difference Measured for the Primary Reference Electrodes Under Test with Respect to Respective MPCMS Primary Reference Electrode Held at $25^{\circ} \mathrm{C}$ in the 241-AY-101 Test Cell.

Table 3-5. Potential Differences Measured for the Primary Reference Electrodes Under Test with Respect to Respective MPCMS Primary Reference Electrode Held at $25^{\circ} \mathrm{C}$ in the $241-\mathrm{AN}-107$ Test Cell.

Table 3-6. Measured Potential Difference Recorded for 241-AY-102 Failed Secondary Reference Electrodes with Respect to Each MPCMS Primary

Reference Electrode Compared to Data from Table 3-2.

Table 4-1. Electrode Electrolyte Contamination Test Matrix. 


\section{LIST OF TERMS}

\section{Terms}

Calomel Electrode. A reference electrode composed of mercury, mercurous chloride (calomel), and an aqueous potassium chloride solution.

Copper/Copper Sulfate. Used in reference to the $\mathrm{Cu} / \mathrm{CuSO}_{4}$ reference electrode, a reference electrode composed of a copper wire immersed in a solution of copper sulfate.

Saturated Calomel Electrode. A reference electrode composed of mercury, mercurous chloride (calomel), and a saturated aqueous potassium chloride solution.

Silver/Silver Chloride. Used in reference to the $\mathrm{Ag} / \mathrm{AgCl}$ reference electrode, a reference electrode composed of a silver wire coated in a thin layer of silver chloride immersed in a solution of potassium chloride).

$\begin{array}{ll}\text { Abbreviations and Acronyms } \\ \text { AAR } & \text { Association of American Railroads } \\ \mathrm{Ag} & \text { Silver } \\ \mathrm{Ag} / \mathrm{AgCl} & \text { Silver/Silver Chloride } \\ \mathrm{ASTM} \mathrm{A537} \mathrm{CL1} & \text { American Society for Testing and Materials A537 Class 1 } \\ \text { calomel } & \text { mercurous chloride } \\ \mathrm{Cu} & \text { Copper } \\ \mathrm{Cu} / \mathrm{CuSO} & \text { Copper/Copper Sulfate } \\ \mathrm{ER} & \text { Electrical Resistance } \\ \mathrm{MPCMS} & \text { Multi-Probe Corrosion Monitoring System } \\ \mathrm{Ni} & \text { Nickel } \\ \mathrm{SCE} & \text { Saturated Calomel Electrode } \\ \mathrm{SHE} & \text { Standard Hydrogen Electrode }\end{array}$

\section{Units}

$\Omega \quad$ ohms

${ }^{\circ} \mathrm{C} \quad$ degrees Centigrade

$\mathrm{ft} \quad$ feet

L liter

$\mathrm{ml}$ milliliter

$\mathrm{mV} \quad$ miliVolt

$\mathrm{pH} \quad$ cologarithm of the activity of dissolved hydrogen ions

psi pounds per square inch

V Volt 


\subsection{INTRODUCTION}

In 2007, the design requirements for a new Multi-Probe Corrosion Monitoring System (MPCMS) were developed by the Hanford Tank Farm Contractor and issued in RPP-SPEC-32496, Procurement Specification for AN-102 Corrosion Probe Assembly. Based on these requirements and lessons learned from previous double-shell tank corrosion monitoring systems, a system was designed, fabricated, and installed in Double-shell Tank 241-AN-102 on May 1, 2008. In general, the system was designed to collect corrosion potential and corrosion rate data from a variety of electrodes installed on an in-tank probe.

The corrosion potentials of the tank and tank material electrodes relative to the primary reference electrodes have varied with temperature since the MPCMS has been installed in Tank 241-AN-102. However, the shift is not consistent with that predicted by the temperature coefficients for the primary reference electrodes. Laboratory testing has been performed to better characterize the relationship between electrode potential and temperature as observed in the MPCMS electrodes.

In Fiscal Year 2008, the design requirements for a new MPCMS were developed by the Hanford Tank Farm Contractor, and issued in RPP-SPEC-35429, Procurement Specification for AY-102 Corrosion Probe Assembly. Based on these requirements and lessons learned from previous double-shell tank corrosion monitoring systems, a system was designed, fabricated, and installed in Double-shell Tank 241-AY-102 on March 26, 2009. Like the 241-AN-102 system, the 241-AY-102 system was designed to collect corrosion potential and corrosion rate data from a variety of electrodes installed on an in-tank probe ${ }^{2}$.

Shortly after installation of the 241-AY-102 system, data began indicating a number of electrode failures. In the ensuing troubleshooting process, it was discovered that there is likely some form of liquid inside the in-tank probe body. The nature of the liquid and the mode of entry is still unknown. However, the most likely liquids are tank waste (intruding from outside the probe body), un-reacted foam component liquid (left inside the probe after the foam filling operation), or snow/rain water (intruding from the top of the MPCMS assembly). Laboratory testing has been performed to better characterize the effects of an intruding liquid on data collected from the MPCMS.

In addition to the need to characterize the effects of the liquid intrusion into the MPCMS probe body, it is known that the primary reference electrodes on both the MPCMSs will eventually fail due to the ingress of tank waste into the electrode filling solutions. Since the MPCMS represents a new application for these electrodes, it is unclear as to when such degradation can be expected or what the effect will be on electrode potential. Laboratory testing has been performed to better characterize the effects of electrode contamination.

Unless otherwise noted, in the balance of testing described in this report the electrodes shown in Table 1-1 were utilized.

\footnotetext{
${ }^{2}$ In addition, corrosion monitoring systems similar in design to the 241-AN-102 and 241-AY-102 MPCMS have been installed or are planned for installation in 241-AY-101, 241-AN-107, and 241-AW-104.
} 
RPP-RPT-44463, Rev. 0

Table 1-1. Reference Electrodes Used in Testing.

\begin{tabular}{|c|c|}
\hline Electrode (Name as Used in Report) & \begin{tabular}{|l} 
Description \\
\end{tabular} \\
\hline $\begin{array}{l}\text { MPCMS-Style Silver/Silver Chloride } \\
\text { (Ag/AgCl) Electrode: }\end{array}$ & $\begin{array}{l}\text { A specially-designed } \mathrm{Ag} / \mathrm{AgCl} \text { electrode for } \\
\text { the MPCMS application with a Kynar }{ }^{\circledR 3} \\
\text { body and porous Kynar frit (for radiation } \\
\text { resistance), uses a } 1 \mathrm{M} \text { potassium chloride } \\
\text { filling solution }\end{array}$ \\
\hline $\begin{array}{l}\text { MPCMS-Style Saturated Calomel } \\
\text { Electrode (SCE): }\end{array}$ & $\begin{array}{l}\text { A specially-designed SCE for the MPCMS } \\
\text { application with a Kynar body and porous } \\
\text { Kynar frit (for radiation resistance) }\end{array}$ \\
\hline $\begin{array}{l}\text { MPCMS-Style Copper/Copper Sulfate } \\
\left(\mathrm{Cu} / \mathrm{CuSO}_{4}\right) \text { Electrode: }\end{array}$ & $\begin{array}{l}\text { A specially-designed } \mathrm{Cu} / \mathrm{CuSO}_{4} \text { electrode } \\
\text { for the MPCMS application with a Kynar } \\
\text { body and porous Kynar frit (for radiation } \\
\text { resistance), uses a saturated copper sulfate } \\
\text { filling solution }\end{array}$ \\
\hline Laboratory-Grade $\mathrm{Ag} / \mathrm{AgCl}$ Electrode: & $\begin{array}{c}\text { Laboratory-grade, glass-bodied } \mathrm{Ag} / \mathrm{AgCl} \\
\text { electrode, uses a } 4 \mathrm{M} \text { potassium chloride } \\
\text { filling solution (Beckman Coulter }{ }^{\circledR 4}, \text { Inc., } \\
\text { Model BK511105) }\end{array}$ \\
\hline Laboratory-Grade SCE & $\begin{array}{c}\text { Laboratory-grade, glass-bodied SCE } \\
\text { (Beckman Coulter, Inc., Model BK511101) }\end{array}$ \\
\hline Laboratory-Grade $\mathrm{Cu} / \mathrm{CuSO}_{4}$ Electrode: & $\begin{array}{l}\text { Laboratory-grade, plastic-bodied } \mathrm{Cu} / \mathrm{CuSO}_{4} \\
\text { electrode, uses a saturated copper sulfate } \\
\text { filling solution (M.C. Miller }{ }^{\mathrm{TM}^{5}} \text { Co., Inc. } \\
\text { Model RE-375) }\end{array}$ \\
\hline
\end{tabular}

\subsection{TEMPERATURE TESTING}

\subsection{BACKGROUND AND PURPOSE}

The corrosion potential of Tank 241-AN-102, as measured with respect to the reference electrodes installed on the MPCMS, has trended inversely with waste temperature since the installation of the MPCMS on May 1, 2008. The effect of temperature variation on the potential of traditional standard primary reference electrodes (i.e., $\mathrm{Ag} / \mathrm{AgCl}, \mathrm{SCE}, \mathrm{Cu} / \mathrm{CuSO}_{4}$, etc.) is well understood. The temperature coefficient of a primary reference electrode describes the change in potential of that reference electrode with temperature. The temperature coefficients for several commonly-available standard primary reference electrodes are shown in Table 2-1. In general, the potential of a primary reference electrode decreases relative to the potential of a Standard Hydrogen Electrode (SHE) as temperature increases; however, this known trend only reflects the relative temperature dependencies of the two electrodes being compared. The corrosion

\footnotetext{
${ }^{3}$ Kynar is a registered trademark of Arkema, Inc., Philadelphia, Pennsylvania.

${ }^{4}$ Beckman Coulter is a registered trademark of Beckman Coulter, Inc., Brea, California.

${ }^{5}$ M.C. Miller is a registered trademark of M.C. Miller Co., Inc., Ringwood, New Jersey.
} 
potential of the working electrode itself is also determined by thermodynamic and kinetic factors which can also be temperature sensitive. Thus, in practice, the change in observed corrosion potential is dependent on the relationship between temperature dependencies of both the working and reference electrodes.

Table 2-1. Standard Reference Electrode Temperature Coefficients. ${ }^{6,7}$

\begin{tabular}{|c|c|}
\hline Electrode & Temperature Coefficient $\left(\mathbf{m V} /{ }^{\circ} \mathbf{C}\right)$ \\
\hline $\mathrm{SCE}$ & 0.22 \\
\hline $\mathrm{Ag} / \mathrm{AgCl}(1 \mathrm{M}$ potassium chloride $)$ & 0.25 \\
\hline $\mathrm{Calomel}(1 \mathrm{M}$ potassium chloride $)$ & 0.59 \\
\hline $\mathrm{Cu} / \mathrm{CuSO}_{4}$ (saturated) & 0.90 \\
\hline $\mathrm{Ag} / \mathrm{AgCl}(4 \mathrm{M}$ potassium chloride $)$ & 1.00 \\
\hline
\end{tabular}

Average corrosion potentials of the tank and tank material electrodes relative to the primary reference electrodes installed on the MPCMS have varied by approximately $16 \mathrm{mV}$ during the operation of the 241-AN-102 MPCMS. Tank waste temperatures have varied by approximately $4^{\circ} \mathrm{C}$ over this same time period. The temperature coefficients for standard primary reference electrodes would predict a $0.88-4 \mathrm{mV}$ shift in potential over a $4^{\circ} \mathrm{C}$ temperature range. Thus, the observed change in potential in the MPCMS-style electrodes cannot be fully explained by the temperature coefficients of standard primary reference electrodes.

Laboratory testing was performed to better characterize the relationship between electrode potential and temperature as observed in MPCMS electrodes. The test plan is detailed in RPP-PLAN-43915, Test Plan for Evaluating the Influence of Temperature on MPCMS Electrode Corrosion Potentials. Test results are expected to aid in the evaluation of field data from the 241-AN-102 MPCMS, as well as MPCMSs installed in other tanks.

\subsection{EXPERIMENTAL SETUP}

For the temperature testing program, the experimental apparatus consisted of two test cells, each containing the following:

1. One each of the MPCMS-style primary reference electrodes (i.e., $\mathrm{Ag} / \mathrm{AgCl}$, $\mathrm{Cu} / \mathrm{CuSO}_{4}$, and calomel electrodes under test),

2. One tank material electrode under test,

3. One condenser, and

4. Approximately one liter of 241-AY-101 or 241-AN-107 tank waste simulant (simulant compositions shown in Appendix A).

\footnotetext{
${ }^{6}$ From "NACE Corrosion Engineers Reference Book, Third Edition" (Baboian 2002), p. 91.

${ }^{7}$ From "Fundamentals of Analytical Chemistry" (7th Edition) (Skoog, West, and Holler 1996), p. 388.
} 
Both of the Teflon ${ }^{\circledR 8}$ test cells containing the electrodes under test were immersed in an insulated bath. Temperature control of the bath was attained using a PolyScience ${ }^{(\mathbb{8} 9}$ Model 7306 temperature controller and water-cooled copper cooling coils (see Appendix B for calibration details). A condenser was used in each of the test cells to help minimize losses due to evaporation. A second constant temperature bath was set up to hold a set of MPCMS-style primary reference electrodes and a set of laboratory-grade primary reference electrodes at $25^{\circ} \mathrm{C}$. The constant-temperature electrodes were partially immersed in a beaker of $1 \mathrm{M}$ potassium chloride solution and the beaker was partially immersed in the $25^{\circ} \mathrm{C}$ bath. A set of a potassium chloride salt bridges were installed between each test cell containing the electrodes under test and the $25^{\circ} \mathrm{C}$ reference electrode cell. The use of salt bridges facilitated potential measurements while minimizing solution contamination of the reference electrodes held at $25^{\circ} \mathrm{C}$. Figure $2-1$ depicts the overall experimental setup. Figure 2-2 shows the details of the temperature test setup.

Figure 2-1. General Experimental Setup (Salt Bridges Highlighted for Clarity).

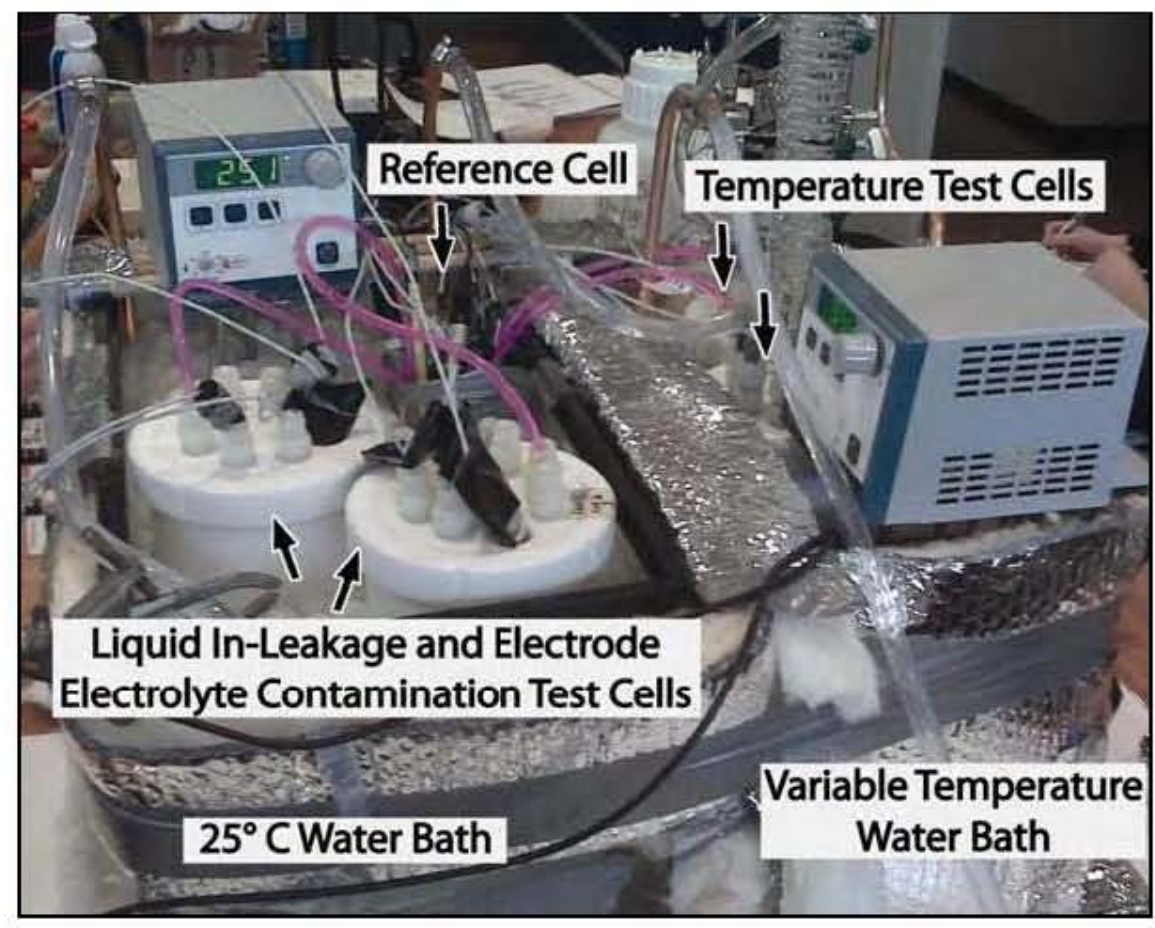

\footnotetext{
${ }^{8}$ Teflon is a registered trademark of E. I. du Pont de Nemours and Company, Wilmington, Delaware.

${ }^{9}$ PolyScience is a registered trademark of Preston Industries, Inc. dba PolyScience Corporation, Niles, Illinois.
} 
Figure 2-2. Temperature Test Apparatus.

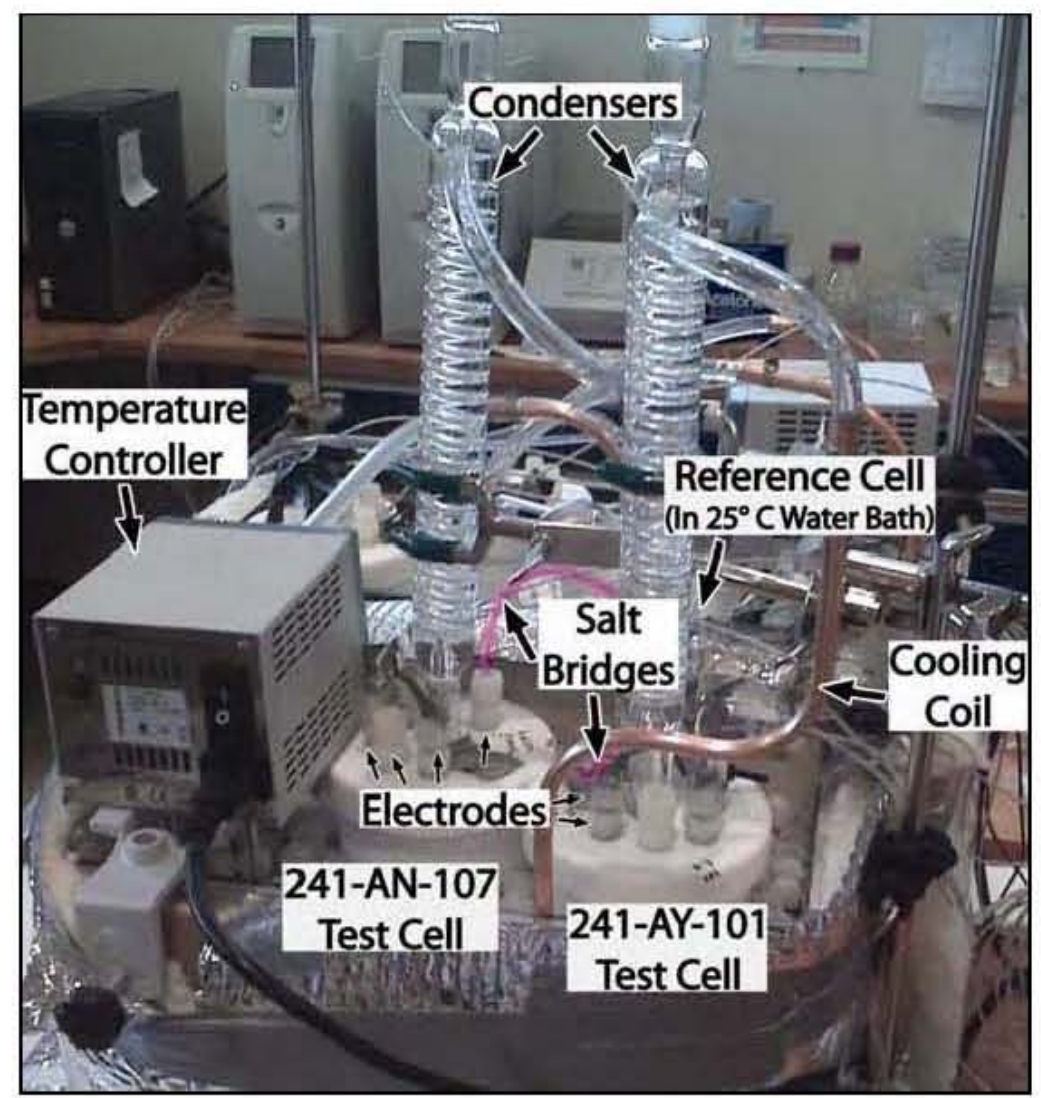

The general test procedure is described below:

1. Fill Test Cell \#1 with at least $1 \mathrm{~L}$ of $241-\mathrm{AY}-101$ simulant.

2. Immerse an Association of American Railroads (AAR) TC128 electrode into Test Cell \#1.

3. Immerse one of each of the three types of MPCMS primary reference electrodes in Test Cell \#1 (calomel, $\mathrm{Cu} / \mathrm{CuSO}_{4}, \mathrm{Ag} / \mathrm{AgCl}$ ).

4. Fill Test Cell \#2 with at least $1 \mathrm{~L}$ of $241-\mathrm{AN}-107$ simulant.

5. Immerse an American Society for Testing and Materials A537 Class 1 (ASTM A537 CL1) electrode into Test Cell \#2.

6. Immerse one of each of the three types of MPCMS primary reference electrodes in Test Cell \#2 (calomel, $\mathrm{Cu} / \mathrm{CuSO}_{4}, \mathrm{Ag} / \mathrm{AgCl}$ ).

7. Set aside one of each of the three types of MPCMS primary reference electrodes (calomel, $\mathrm{Cu} / \mathrm{CuSO}_{4}, \mathrm{Ag} / \mathrm{AgCl}$ ) and allow to equilibrate at $25^{\circ} \mathrm{C}$. 
8. Set aside one of each of the three types of laboratory-grade primary reference electrodes (calomel, $\mathrm{Cu} / \mathrm{CuSO}_{4}, \mathrm{Ag} / \mathrm{AgCl}$ ) and allow to equilibrate at $25^{\circ} \mathrm{C}$.

9. Immerse Test Cell \#1 and Test Cell \#2 in a constant temperature bath and allow test temperature and electrode potentials to equilibrate at approximately $25^{\circ} \mathrm{C}$.

10. After test cell temperature and electrode potentials have stabilized, make the following measurements in each test cell and record these measurements on the data sheets provided in Appendix C:

- Test solution $\mathrm{pH}$, bath temperature, and mark time and date.

- Measure the potentials of the ASTM A537 CL1 and AAR TC128 electrodes under test with respect to:

- Each of the three MPCMS-style primary reference electrodes that are immersed in the respective test cells (calomel, $\mathrm{Cu} / \mathrm{CuSO}, \mathrm{Ag} / \mathrm{AgCl}$ ),

- Each of the three $25^{\circ} \mathrm{C}$ MPCMS-style primary reference electrodes (calomel, $\mathrm{Cu} / \mathrm{CuSO}_{4}, \mathrm{Ag} / \mathrm{AgCl}$ ), and

- Each of the three $25^{\circ} \mathrm{C}$ laboratory-grade primary reference electrodes (calomel, $\mathrm{Cu} / \mathrm{CuSO}_{4}, \mathrm{Ag} / \mathrm{AgCl}$ ).

- Measure the potentials of each of the MPCMS-style primary reference electrodes under test (calomel, $\mathrm{Cu} / \mathrm{CuSO}_{4}, \mathrm{Ag} / \mathrm{AgCl}$ ) with respect to a $25^{\circ} \mathrm{C}$ MPCMS-style reference electrode of the same type and a $25^{\circ} \mathrm{C}$ laboratory-grade reference electrode of the same type (e.g., measure the potential of the MPCMS-style calomel primary reference electrode under test with respect to a $25^{\circ} \mathrm{C}$ MPCMSstyle and laboratory-grade calomel primary reference electrode, etc.).

11. Elevate test cell temperatures by approximately $2^{\circ} \mathrm{C}$ and allow to stabilize. Repeat the potential measurements described in Step 10 at the new test temperature. Repeat this process of increasing the cell temperature by $2^{\circ} \mathrm{C}$ and making the measurements described in Step 10 between $25^{\circ} \mathrm{C}$ and $35^{\circ} \mathrm{C}$. Note that cell temperature must be constant before measurements are made.

12. Between $35^{\circ} \mathrm{C}$ and $60^{\circ} \mathrm{C}$, continue the iterative process of increasing the cell temperature and making the measurements described in Step 10, but increase cell temperature in $5^{\circ} \mathrm{C}$ increments. Note that cell temperature must be constant before measurements are made.

13. If time allows, repeat the measurements described in Step 10, but while lowering the test cell temperatures in $5^{\circ} \mathrm{C}$ increments from $60^{\circ} \mathrm{C}$ to $35^{\circ} \mathrm{C}$, then in $2^{\circ} \mathrm{C}$ increments from $35^{\circ} \mathrm{C}$ to $25^{\circ} \mathrm{C}$. Note that cell temperature must be constant before measurements are made. 
The test matrix is shown in Table 2-2. Test exceptions for the procedure detailed in RPP-PLAN43915 are listed in Appendix D.

Table 2-2. Temperature Test Matrix.

\begin{tabular}{|c|c|c|c|}
\hline Working Electrodes & \multicolumn{2}{|c|}{ Reference Electrodes } & Temperature Range \\
\hline \multirow{2}{*}{$\begin{array}{c}\text { MPCMS-style } \mathrm{Ag} / \mathrm{AgCl} \\
\text { (Temperature Range } 25^{\circ} \mathrm{C}-60^{\circ} \mathrm{C} \text { ) }\end{array}$} & \multicolumn{2}{|c|}{ MPCMS-style $\mathrm{Ag} / \mathrm{AgCl}$} & $25^{\circ} \mathrm{C}$ \\
\hline & \multicolumn{2}{|c|}{ Laboratory-grade $\mathrm{Ag} / \mathrm{AgCl}$} & $25^{\circ} \mathrm{C}$ \\
\hline \multirow{2}{*}{$\begin{array}{c}\text { MPCMS-style Calomel } \\
\text { (Temperature Range } 25^{\circ} \mathrm{C}-60^{\circ} \mathrm{C} \text { ) }\end{array}$} & \multicolumn{2}{|c|}{ MPCMS-style Calomel } & $25^{\circ} \mathrm{C}$ \\
\hline & \multicolumn{2}{|c|}{ Laboratory-grade Calomel } & $25^{\circ} \mathrm{C}$ \\
\hline \multirow{2}{*}{$\begin{array}{c}\text { MPCMS-style } \mathrm{Cu} / \mathrm{CuSO}_{4} \\
\text { (Temperature Range } 25^{\circ} \mathrm{C}-60^{\circ} \mathrm{C} \text { ) }\end{array}$} & \multicolumn{2}{|c|}{ MPCMS-style $\mathrm{Cu} / \mathrm{CuSO}_{4}$} & $25^{\circ} \mathrm{C}$ \\
\hline & \multicolumn{2}{|c|}{ Laboratory-grade $\mathrm{Cu} / \mathrm{CuSO}_{4}$} & $25^{\circ} \mathrm{C}$ \\
\hline \multirow{9}{*}{$\begin{array}{l}\text { AAR TC- } 128 \text { or ASTM A537 CL1 } \\
\text { (Temperature Range } 25^{\circ} \mathrm{C}-60^{\circ} \mathrm{C} \text { ) }\end{array}$} & \multirow{3}{*}{ MPCMS-style under test } & $\mathrm{Ag} / \mathrm{AgCl}$ & $25^{\circ} \mathrm{C}-60^{\circ} \mathrm{C}$ \\
\hline & & Calomel & $25^{\circ} \mathrm{C}-60^{\circ} \mathrm{C}$ \\
\hline & & $\mathrm{Cu} / \mathrm{CuSO}_{4}$ & $25^{\circ} \mathrm{C}-60^{\circ} \mathrm{C}$ \\
\hline & \multirow{3}{*}{ MPCMS-style } & $\mathrm{Ag} / \mathrm{AgCl}$ & $25^{\circ} \mathrm{C}$ \\
\hline & & Calomel & $25^{\circ} \mathrm{C}$ \\
\hline & & $\mathrm{Cu} / \mathrm{CuSO}_{4}$ & $25^{\circ} \mathrm{C}$ \\
\hline & \multirow{3}{*}{ Laboratory-grade } & $\mathrm{Ag} / \mathrm{AgCl}$ & $25^{\circ} \mathrm{C}$ \\
\hline & & Calomel & $25^{\circ} \mathrm{C}$ \\
\hline & & $\mathrm{Cu} / \mathrm{CuSO}_{4}$ & $25^{\circ} \mathrm{C}$ \\
\hline
\end{tabular}

The temperature was adjusted by increasing (or decreasing) the temperature by two degrees between the temperatures of $25^{\circ} \mathrm{C}$ and $35^{\circ} \mathrm{C}$. Smaller temperature intervals were used to obtain higher potential resolution at temperatures typically maintained in waste tanks. The temperature was increased (or decreased) in increments of five degrees between the temperatures of $35^{\circ} \mathrm{C}$ and $60^{\circ} \mathrm{C}$. Larger increments were utilized at higher temperatures where potential resolution was not as essential, but general trends in data were sought.

Temperatures were allowed to stabilize for approximately 2-3 hours before each set of electrode potential measurements were collected. However, because temperature measurements were not taken at equal time intervals for the duration of the experiment, the potential data is presented with respect to temperature instead of time.

\subsection{RESULTS}

The results of testing to characterize the relationship between MPCMS-style primary reference electrode potential and temperature in 241-AY-101 waste simulant and 241-AN-107 waste simulant are shown in Figures 2-3 and 2-4, respectively. The results of testing to characterize the relationship between tank steel electrode potential and temperature in 241-AY-101 waste simulant and 241-AN-107 waste simulant are shown in Figures 2-5 and 2-6, respectively.

Due to the large amount of data collected in the test program, it is not possible or necessary to show all data to summarize the general results of testing. Instead, selected data representative of the results of testing are presented below in an effort to summarize the general results of testing. Additional test data are shown in Appendix E should the reader wish to investigate the results of testing in greater detail. 
Figure 2-3. Potential of MPCMS-Style Primary Reference Electrodes Under Test in 241-AY-101 Waste Simulant at Various Temperatures with Respect to MPCMS-Style Primary Reference Electrodes Held at $25^{\circ} \mathrm{C}$.

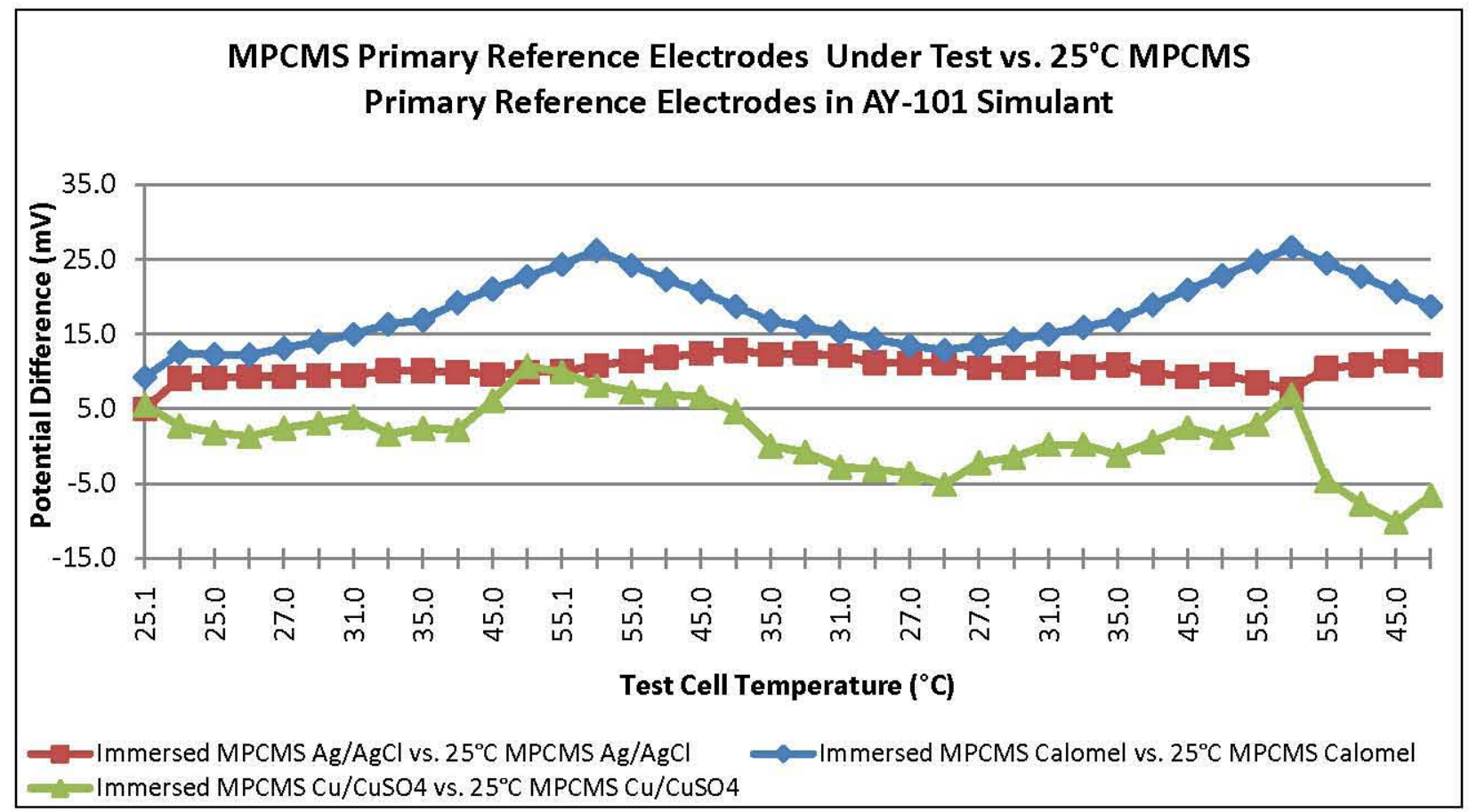

Figure 2-4. Potential of MPCMS-Style Primary Reference Electrodes Under Test in 241-AN-107 Waste Simulant at Various Temperatures with Respect to MPCMS-Style Primary Reference Electrodes Held at $25^{\circ} \mathrm{C}$.

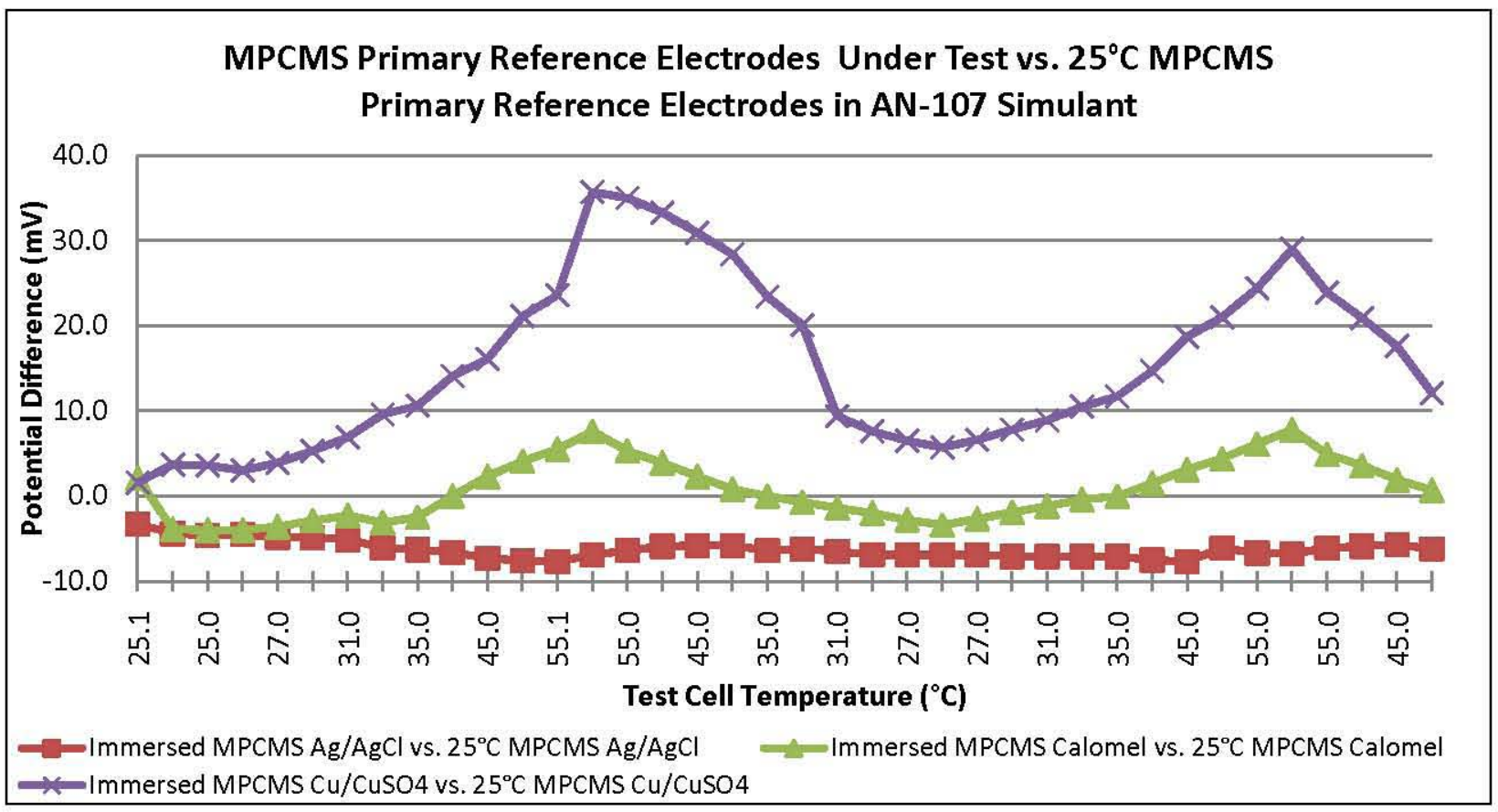


RPP-RPT-44463, Rev. 0

Figure 2-5. Potential of AAR TC128 Steel Electrode Under Test in 241-AY-101 Waste Simulant at Various Temperatures with Respect to MPCMS-Style Primary Reference Electrodes Held at $25^{\circ} \mathrm{C}$.

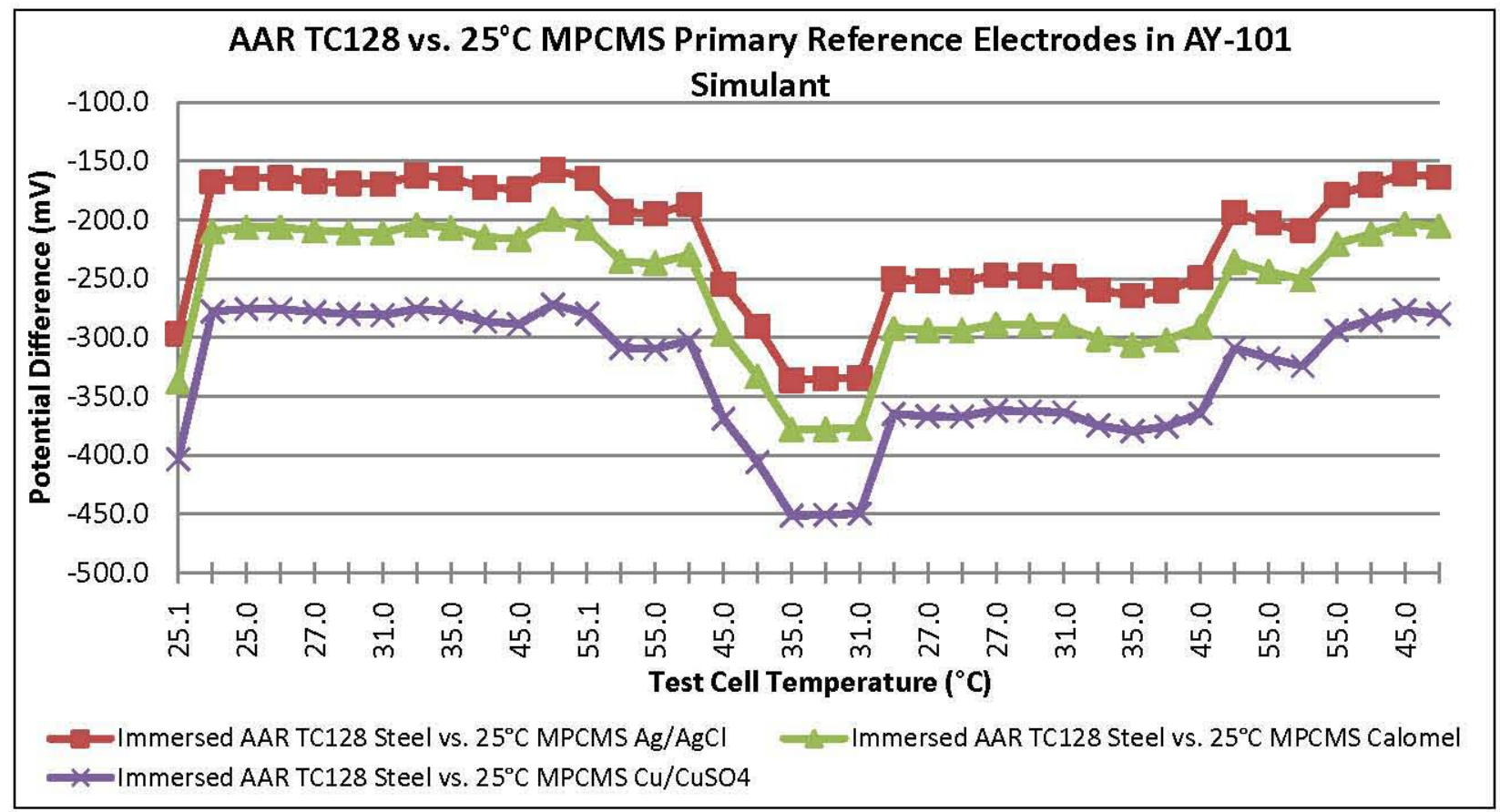

Figure 2-6. Potential of ASTM A537 CL1 Steel Electrode Under Test in 241-AN-107 Waste Simulant at Various Temperatures with Respect to MPCMS-Style Primary Reference Electrodes Held at $25^{\circ} \mathrm{C}$.

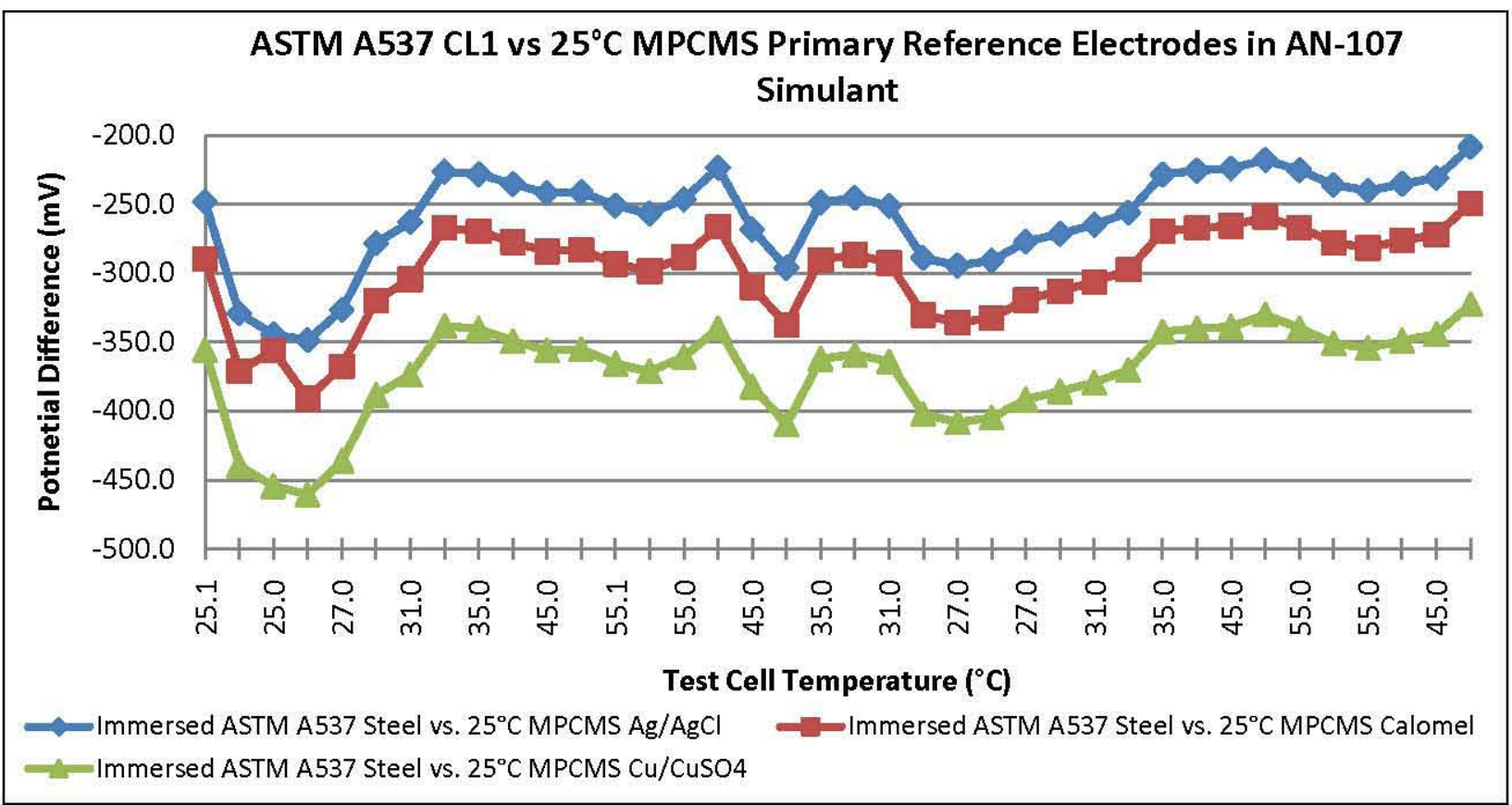




\subsection{DISCUSSION}

In general, testing of the MPCMS-style primary reference electrodes showed a relatively direct relationship between temperature and electrode potential. This trend is particularly apparent in the MPCMS-style calomel reference electrodes as measured with respect to the MPCMS-style calomel reference electrodes held at $25^{\circ} \mathrm{C}$. The trend is similar, but less pronounced in the MPCMS-style $\mathrm{Ag} / \mathrm{AgCl}$ electrodes and similar, and similar but more erratic for the MPCMSstyle $\mathrm{Cu} / \mathrm{CuSO}_{4}$ electrodes. The difference in magnitude of potential shifts with temperature between the calomel and $\mathrm{Ag} / \mathrm{AgCl}$ electrodes is not clearly related to the differences in the magnitude of the temperature coefficients for these two electrodes (i.e., $0.22 \mathrm{mV} /{ }^{\circ} \mathrm{C}$ for the calomel electrode and $1.00 \mathrm{mV} /{ }^{\circ} \mathrm{C}$ for the $\mathrm{Ag} / \mathrm{AgCl}$ electrode). The erratic behavior of the $\mathrm{Cu} / \mathrm{CuSO}_{4}$ electrode is likely due to changes in solubility of $\mathrm{CuSO}_{4}$ with temperature (i.e., the stability of the potential of $\mathrm{Cu} / \mathrm{CuSO}_{4}$ reference electrodes is dependent on maintaining a saturated $\mathrm{CuSO}_{4}$ solution within the electrode).

The results of the experimental work generally mimic data obtained from the MPCMS currently installed in tank 241-AN-102, where measured potentials for all three types of primary reference electrodes fluctuate with temperature. Recent field data from the 241-AN-102 MPCMS is available in RPP-RPT-38932, 241-AN-102 Multi-Probe Corrosion Monitoring System: September, October, and November Quarterly Report. ${ }^{10}$ In the upper regions of the tank, fluctuations in electrode potential appear to be more inversely related to temperature than in the lower regions of the tank. However, this could be due, at least in part, to the relative locations of the thermocouples with respect to the MPCMS.

In both the laboratory tests and in the field data, the primary reference electrode potentials appear to shift by approximately $4 \mathrm{mV} /{ }^{\circ} \mathrm{C}$. In addition, tank steel in both waste simulants showed no significant trend with temperature. The large variations in potential of the steel electrodes over time is more likely related to the passivation of the electrode surfaces. This observed potential shift in both laboratory and field data is approximately 4 to 8 times the shift predicted by the electrode temperature coefficients. Since the laboratory test data are similar to tank data, it is assumed that this large shift is not related to the waste tank environment. The shift may be related to the MPCMS primary reference electrode design, possibly having to do with the movement of electrolyte through the porous Kynar electrode tip, or with the unique gel-type filling solution used in the MPCMS-style electrodes. The shift observed in the tank data does not appear to be related to electrode malfunction.

\subsection{LIQUID IN-LEAKAGE TESTING}

\subsection{BACKGROUND AND PURPOSE}

Shortly after the installation of the MPCMS into Tank 241-AY-102, the data recorded from the MPCMS began to indicate a number of electrode failures. Details of these failures can be found in RPP-RPT-40661, 241-AY-102 Multi-Probe Corrosion Monitoring System: Weeks 13 and 14

${ }^{10}$ The 241-AN-107 waste simulant was designed to be similar to the waste found in the supernatant region for Tanks 241-AN-102 and 241-AN-107. 
Report. In the ensuing troubleshooting process, it was discovered that some of the cable shields were no longer effectively isolated from the test return lead (i.e., relatively low leakage resistances were measured between some of the cable shields and the test return lead attached to the tank riser). The leakage resistances were notew orthy since during factory acceptance testing all cable shields were electrically isolated from the probe body and other conductors (measured as $>20 \mathrm{M} \Omega$ resistance). ${ }^{11}$ Likewise, during construction acceptance testing shortly before system installation, the electrical isolation between cable shields and conductors was re-tested and confirmed (measured as $>400 \mathrm{M} \Omega$ resistance). ${ }^{12}$ Test results indicate that all cable shields associated with electrodes and Electrical Resistance (ER) sensors in the lower $\sim 19.5 \mathrm{ft}$ of the fixed probe (i.e., the electrodes and the ER sensor in the sludge layer of the tank and the supernatant ER sensor) are no longer electrically isolated from the test return lead. Leakage resistance between these shields and the test return lead range from $383 \Omega$ to $120 \mathrm{k} \Omega$. At higher elevations on the probe, the supernatant electrode cable shields remain isolated from the test return (i.e., leakage resistance $>400 \mathrm{M} \Omega$ ). Field measurements from the June 22, 2009 troubleshooting tests taken by Washington River Protection Solutions, LLC personnel can be found in RPP-RPT-40661.

To compromise the electrical isolation of the cable shields inside the probe body, a conductive electrolyte not present during factory or construction acceptance testing must now be present inside the in-tank probe body. To make contact with the shields, the intruding electrolyte would also have to seep under the heat shrink tubing at the electrode-ends of the cables. ${ }^{13}$ The type of liquid that appears to be inside the probe and the mode of entry is still unknown.

It is possible, though unlikely, that an interface between the fixed probe body and a primary reference electrode, secondary reference electrode, or ER sensor could be providing a leakage path for tank waste. However, these interface points are specifically designed to prevent waste in-leakage and all interfaces and joints passed helium leak detection testing following fabrication (as documented in RPP-RPT-40633). Still, tank waste in-leakage must be considered based on the number of affected shields, the fact that tank waste is thought to be capable of dissolving the two-part foam, and the gradual change in the measured shield leakage resistances evident in the troubleshooting over time. For waste to enter at the interface between an electrode (either primary or secondary) or ER sensor and the probe body, the waste would have to overcome either a threaded National Pipe Thread connection or a Swagelok ${ }^{\circledR 14}$ fitting and/or a compressed glass-to-metal seal (rated by the manufacturer to withstand pressures of 3,600 psi).

Theoretically, one of the glass-to-metal seals could have cracked or been damaged during installation, but typically only hairline cracks form in these seals, if they fail at all, and this type of crack should not allow liquid entry.

Another plausible scenario is that the two component liquids that make up the two-part foam used to fill the fixed probe body may not have completely reacted during injection. Residual

\footnotetext{
${ }^{11}$ RPP-RPT-40633, Factory Acceptance Test Report for the 241-AY-102 Multi-Probe Corrosion Monitoring System.

${ }^{12}$ RPP-RPT-40867, Construction Acceptance and Process Test Report for the 241-AY-102 Multi-Probe Corrosion Monitoring System.

${ }^{13}$ Inside the probe, each primary and secondary reference electrode cable shield is cut back and insulated with heat shrink tubing at the interface with the back of the electrode (i.e., shields are not connected to anything at electrode end of cable).

${ }^{14}$ Swagelok is a registered trademark of Swagelok Company, Solon, Ohio.
} 
component fluid left inside the fixed probe body could migrate over time, either by gravity or by wicking up cable bundles. Based on a similar problem experienced (and corrected) during the 241-AY-101 MPCMS fabrication process, it is known that at least one of the individual components used to make up the two-part foam is conductive prior to reaction (cured foam is not conductive). Full reaction of both components is not guaranteed during the injection/mixing process used to fill the probe body with foam; thus, conductive foam component liquid could now be in contact with electrode cables or shields. However, the fact that the problem went undetected during leak detection cable checks performed in both the factory acceptance test and construction acceptance tests, as well as continuity testing during factory acceptance testing (RPP-RPT-40633) and construction acceptance testing (RPP-RPT-40867), makes it difficult to understand how a substantial quantity of un-reacted foam component liquid could be present inside the probe.

Other modes of failure have been also been considered (i.e., condensation, external moisture inleakage, tank waste leakage at welded fittings or stud welds, etc.), but these modes appear to be even more unlikely than waste in-leakage or the presence of un-reacted foam component liquid.

No data are available in the literature to characterize the effects of an intruding liquid on data collected from the MPCMS, so laboratory testing has been performed to characterize these phenomena. The test plan is detailed in RPP-PLAN-43916, Test Plan for Evaluating the Effects of MPCMS Primary Reference Electrode Electrolyte Contamination and MPCMS Probe Body Liquid In-Leakage. Test results are expected to aid in the evaluation of field data from the Tank 241-AY-102 MPCMS, and MPCMSs installed in other tanks.

\subsection{EXPERIMENTAL SETUP}

The liquid in-leakage experimental apparatus consisted of two test cells, each containing the following:

1. One each of the MPCMS-style primary reference electrodes (i.e., $\mathrm{Ag} / \mathrm{AgCl}$, $\mathrm{Cu} / \mathrm{CuSO}_{4}$, and calomel electrodes under test);

2. One tank material electrode under test;

3. One of each of the secondary reference electrodes [i.e., silver $(\mathrm{Ag})$, copper $(\mathrm{Cu})$, and nickel (Ni) under test]; and

4. Approximately one liter of tank waste stimulant from either 241-AY-101 or 241-AN-107 tanks.

Both test cells containing the electrodes under test were immersed in an insulated bath. Temperature control of the bath was attained using a PolyScience Model 7306 temperature controller and water-cooled copper cooling coils. A condenser was used in each of the test cells to help minimize losses due to evaporation. A second constant temperature bath was set up to hold a set of MPCMS-style primary reference electrodes and a set of laboratory-grade primary reference electrodes at $25^{\circ} \mathrm{C}$. The constant-temperature electrodes were partially immersed in a beaker of $1 \mathrm{M}$ potassium chloride solution and the beaker was partially immersed in the $25^{\circ} \mathrm{C}$ 
bath. A set of a potassium chloride salt bridges were installed between each test cell containing the electrodes under test and the $25^{\circ} \mathrm{C}$ reference electrode cell. The use of salt bridges facilitated potential measurements while minimizing solution contamination of the reference electrodes held at $25^{\circ} \mathrm{C}$. Figure 3-1 depicts the experimental setup for the liquid in-leakage test.

Figure 3-1. Liquid In-L eakage T est Apparatus (Salt Bridges Not Shown).

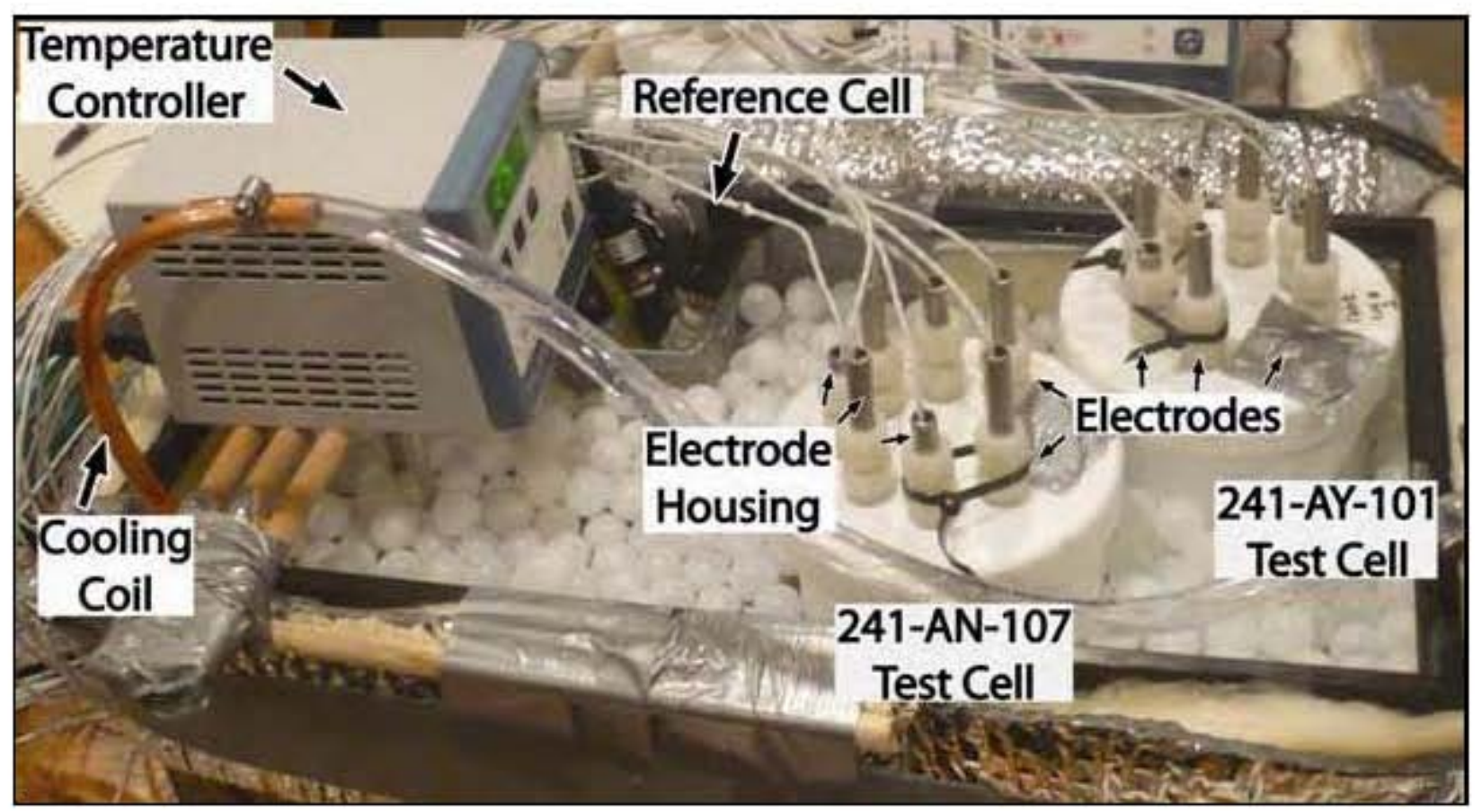

The general test procedure is described below:

1. Fill Test Cell \#1 with at least $1 \mathrm{~L}$ of $241-\mathrm{AY}-101$ simulant.

2. Immerse an AAR TC128 electrode into Test Cell \#1.

3. Immerse $\mathrm{Cu}, \mathrm{N}_{1}$, and $\mathrm{Ag}$ secondary reference electrodes into Test Cell \#1.

4. Immerse one of each of the three types of MPCMS primary reference electrodes in Test Cell \#1 (calomel, $\mathrm{Cu} / \mathrm{CuSO}_{4}, \mathrm{Ag} / \mathrm{AgCl}$ ).

5. Fill Test Cell \#2 with at least $1 \mathrm{~L}$ of $241-\mathrm{AN}-107$ simulant.

6. Immerse an ASTM A537 CL1 electrode into Test Cell \#2.

7. Immerse $\mathrm{Cu}, \mathrm{N}_{1}$, and $\mathrm{Ag}$ secondary reference electrodes into Test Cell \#2.

8. Immerse one of each of the three types of MPCMS primary reference electrodes in Test Cell \#2 (calomel, $\mathrm{Cu} / \mathrm{CuSO}, \mathrm{Ag} / \mathrm{AgCl}$ ). 
9. Immerse Test Cell \#1 and Test Cell \#2 in a constant temperature bath and allow test cell temperatures time to equilibrate at approximately $35^{\circ} \mathrm{C}$.

10. Set aside one of each of the three types of MPCMS primary reference electrodes (calomel, $\mathrm{Cu} / \mathrm{CuSO}_{4}, \mathrm{Ag} / \mathrm{AgCl}$ ) and allow to equilibrate at $25^{\circ} \mathrm{C}$.

11. Set aside one of each of the three types of laboratory-grade primary reference electrodes (calomel, $\mathrm{Cu} / \mathrm{CuSO}_{4}, \mathrm{Ag} / \mathrm{AgCl}$ ) and allow to equilibrate at $25^{\circ} \mathrm{C}$.

12. After test cell temperature and electrode potentials have stabilized, make the following measurements in each test cell and record the measurements on the data sheets provided in Appendix C:

- Test solution $\mathrm{pH}$, bath temperature, and mark time and date,

- Measure the potentials of the ASTM A537 CL1, AAR TC128, Cu, Ni, and Ag secondary reference electrodes under test with respect to:

- Each of the three MPCMS-style primary reference electrodes that are under test in the respective test cells (calomel, $\mathrm{Cu} / \mathrm{CuSO}_{4}, \mathrm{Ag} / \mathrm{AgCl}$ ),

- Each of the three $25^{\circ} \mathrm{C}$ MPCMS-style primary reference electrodes (calomel, $\mathrm{Cu} / \mathrm{CuSO}_{4}, \mathrm{Ag} / \mathrm{AgCl}$ ), and

- Each of the three $25^{\circ} \mathrm{C}$ laboratory-grade primary reference electrodes (calomel, $\mathrm{Cu} / \mathrm{CuSO}_{4}, \mathrm{Ag} / \mathrm{AgCl}$ ).

- Measure the potentials of each of the MPCMS-style primary reference electrodes (calomel, $\mathrm{Cu} / \mathrm{CuSO}_{4}, \mathrm{Ag} / \mathrm{AgCl}$ ) under test with respect to a $25^{\circ} \mathrm{C}$ MPCMS-style reference electrode of the same type and a $25^{\circ} \mathrm{C}$ laboratory-grade reference electrode of the same type (e.g., measure the potential of the MPCMS-style calomel primary reference electrode under test with respect to a $25^{\circ} \mathrm{C}$ MPCMSstyle and laboratory-grade calomel primary reference electrode, etc.).

- Measure the potential between each electrode under test (MPCMS-style calomel, MPCMS-style $\mathrm{Cu} / \mathrm{CuSO}_{4}, \mathrm{MPCMS}$-style $\mathrm{Ag} / \mathrm{AgCl}$, tank material, $\mathrm{Ni}, \mathrm{Cu}$, and $\mathrm{Ag}$ electrodes) and its respective electrode housing.

13. Wet the back of each electrode under test with water in each test cell. Ensure that there is a continuous path of water between the feed-through body and the feedthrough conductor stud. Repeat the potential measurements described in Step 12 using the feed-throughs that have been wetted with water.

14. Remove the wetted feed-throughs. Clean, dry, and re-install the feed-throughs and electrodes. Allow test cells and electrode potentials to re-equilibrate at $35^{\circ} \mathrm{C}$.

15. Repeat the potential measurements described in Step 12 on the clean feed-throughs. 
16. Wet the back of each feed-through with waste simulant. Ensure that there is a continuous path of waste simulant between the feed-through body and the feedthrough conductor stud. Repeat the potential measurements described in Step 12 using the feed-throughs that have been wetted with waste simulant.

17. Remove the wetted feed-throughs. Clean, dry, and re-install the feed-throughs and electrodes. Allow test cells and electrode potentials to re-equilibrate at $35^{\circ} \mathrm{C}$.

18. Repeat the potential measurements described in Step 12 on the clean feed-throughs.

19. Wet the back of each feed-through with Handi-Foam ${ }^{\circledR 15}$ E84 Class I Spray Foam Part B Component Liquid. Ensure that there is a continuous path of foam component liquid between the feed-through body and the feed-through conductor stud. Repeat the potential measurements described in Step 12 using the feed-throughs that have been wetted with foam component liquid.

The test matrix is shown in Table 3-1. Test exceptions for the procedure detailed in RPP-PLAN43916 are listed in Appendix D.

Table 3-1. Liquid In-Leakage Test Matrix.

\begin{tabular}{|c|c|c|}
\hline Test Electrode & \multicolumn{2}{|c|}{ Electrodes Used as Test Reference } \\
\hline \multirow{3}{*}{ MPCMS-style $\mathrm{Ag} / \mathrm{AgCl}$} & \multicolumn{2}{|c|}{ MPCMS-style $\mathrm{Ag} / \mathrm{AgCl}$} \\
\hline & \multicolumn{2}{|c|}{ Laboratory-grade $\mathrm{Ag} / \mathrm{AgCl}$} \\
\hline & \multicolumn{2}{|c|}{ Electrode Housing } \\
\hline \multirow{3}{*}{ MPCMS-style Calomel } & \multicolumn{2}{|c|}{ MPCMS-style Calomel } \\
\hline & \multicolumn{2}{|c|}{ Laboratory-grade Calomel } \\
\hline & \multicolumn{2}{|c|}{ Electrode Housing } \\
\hline \multirow{3}{*}{ MPCMS-style $\mathrm{Cu} / \mathrm{CuSO}_{4}$} & \multicolumn{2}{|c|}{ MPCMS-style $\mathrm{Cu} / \mathrm{CuSO}_{4}$} \\
\hline & \multicolumn{2}{|c|}{ Laboratory-grade $\mathrm{Cu} / \mathrm{CuSO}_{4}$} \\
\hline & \multicolumn{2}{|c|}{ Electrode Housing } \\
\hline \multirow{10}{*}{$\begin{array}{c}\text { Ag Secondary, } \\
\text { Ni Secondary, } \\
\text { Cu Secondary, and } \\
\text { TC-128 or ASTM A537 CL1 }\end{array}$} & \multirow{3}{*}{ MPCMS-style under test } & $\mathrm{Ag} / \mathrm{AgCl}$ \\
\hline & & Calomel \\
\hline & & $\mathrm{Cu} / \mathrm{CuSO}_{4}$ \\
\hline & \multirow{3}{*}{ MPCMS-style reference } & $\mathrm{Ag} / \mathrm{AgCl}$ \\
\hline & & Calomel \\
\hline & & $\mathrm{Cu} / \mathrm{CuSO}_{4}$ \\
\hline & \multirow{3}{*}{ Laboratory-grade reference } & $\mathrm{Ag} / \mathrm{AgCl}$ \\
\hline & & Calomel \\
\hline & & $\mathrm{Cu} / \mathrm{CuSO}_{4}$ \\
\hline & \multicolumn{2}{|c|}{ Electrode Housing } \\
\hline
\end{tabular}

${ }^{15}$ Handi-Foam is a registered trademark of Fomo Products, Inc., Norton, Ohio. 
RPP-RPT-44463, Rev. 0

\subsection{TANK MATERIAL AND SECONDARY REFERENCE ELECTRODE RESULTS}

NOTE: For the purposes of this discussion, the term "wetted" or "wetted electrode" indicates the presence of some form of liquid on the back of the electrode causing a short between the electrode and the metallic electrode housing.

The measured potentials for the wetted electrodes are presented in Figures 3-2 through 3-9. In each figure, the potential values for the electrode are grouped in order by contamination/cleaning steps as follows:

1. Initial potential, prior to wetting (e.g., Clean Ni),

2. Potential after wetting with water (e.g., Water Ni),

3. Potential after cleaning and drying after water test (e.g., Clean Ni),

4. Potential after wetting with waste simulant (e.g., Waste Ni),

5. Potential after cleaning and drying after waste simulant test (e.g., Clean Ni), and

6. Potential after wetting with foam component B (e.g., Foam Ni).

Due to the large amount of data collected in the test program, it is not possible or necessary to show all data to summarize the general results of testing. Instead, selected data representative of the results of testing are presented below in an effort to summarize the general results of testing. Additional test data are shown in Appendix E should the reader wish to investigate the results of testing in greater detail. 
Figure 3-2. 241-AY-101 Nickel Electrode Wetting. Potential of the Nickel Secondary Reference Electrode is Measured with Respect to the Reference MPCMS-Style Primary Reference Electrodes at Room Temperature in 241-AY-101 Waste Simulant. Groups Represent Individual Contamination Steps.

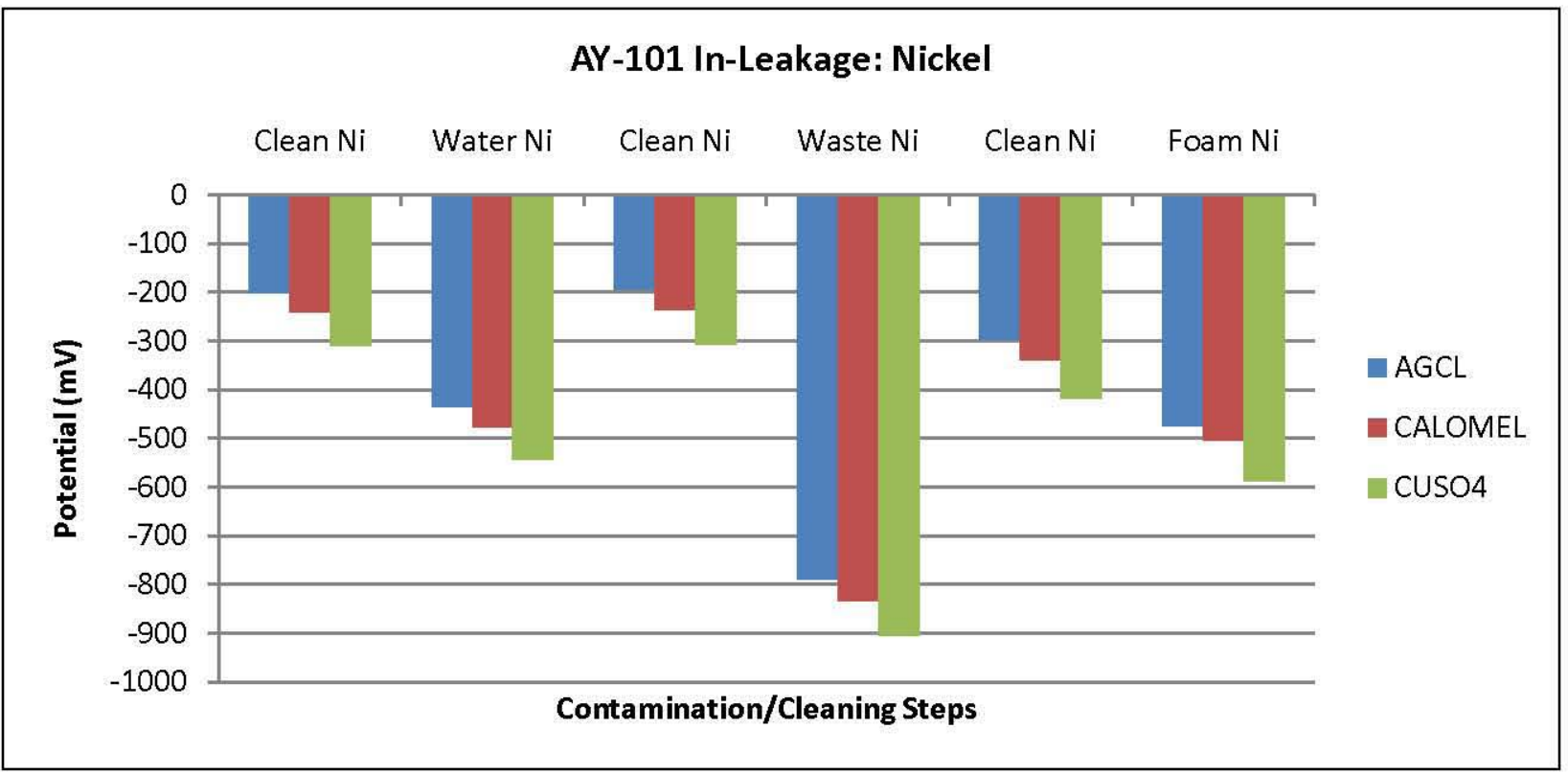

Figure 3-3. 241-AN-107 Nickel Electrode Wetting. Potential of the Nickel Secondary Reference Electrode is Measured with Respect to the Reference MPCMS-Style Primary Reference Electrodes at Room Temperature in 241-AN-107 Waste Simulant. Groups Represent Individual Contamination Steps.

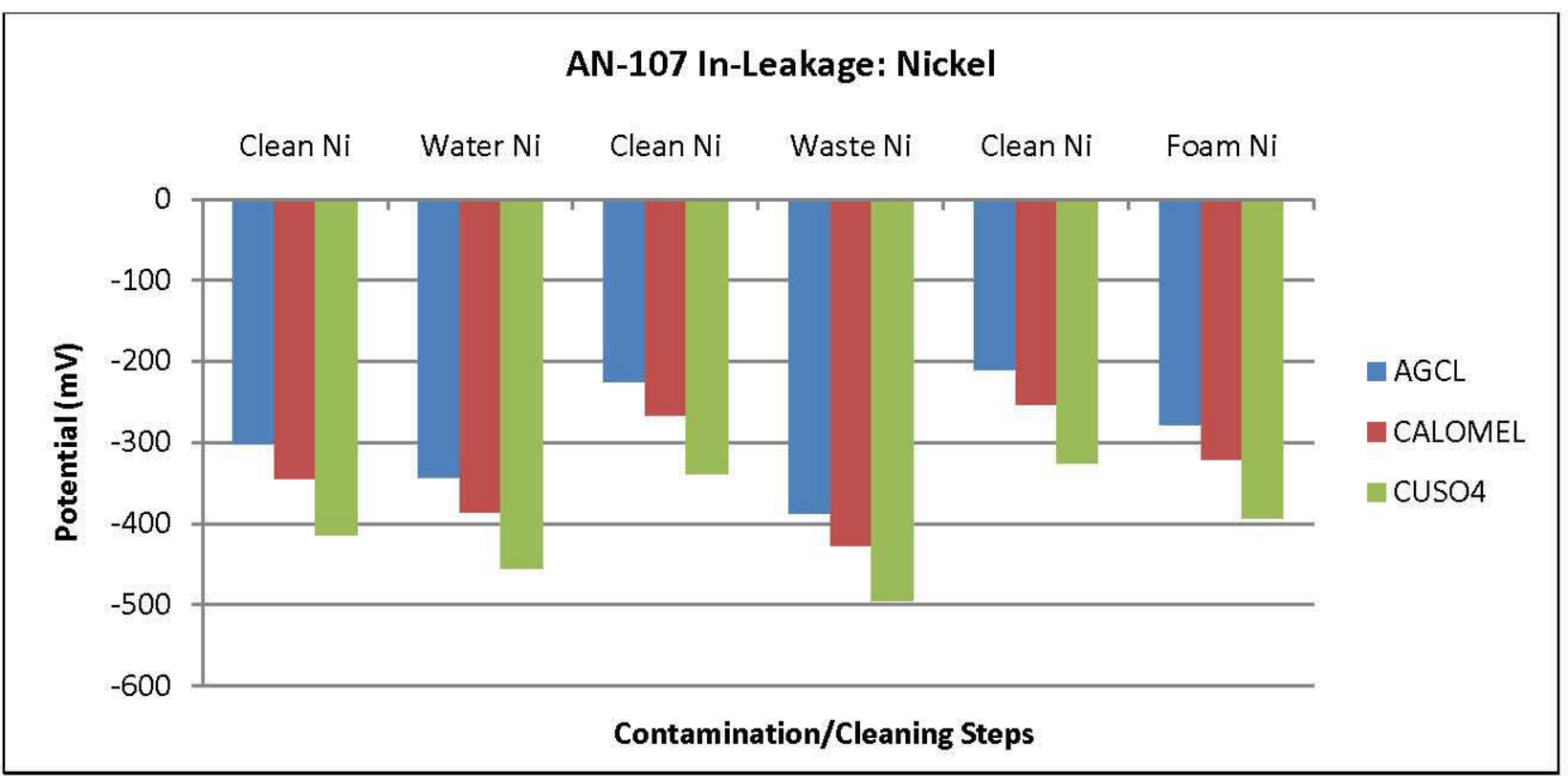


Figure 3-4. 241-AY-101 Copper Electrode Wetting. Potential of the Copper Secondary Reference Electrode is Measured with Respect to the Reference MPCMS-Style Primary Reference Electrodes at Room Temperature in 241-AY-101 Waste Simulant. Groups Represent Individual Contamination Steps.

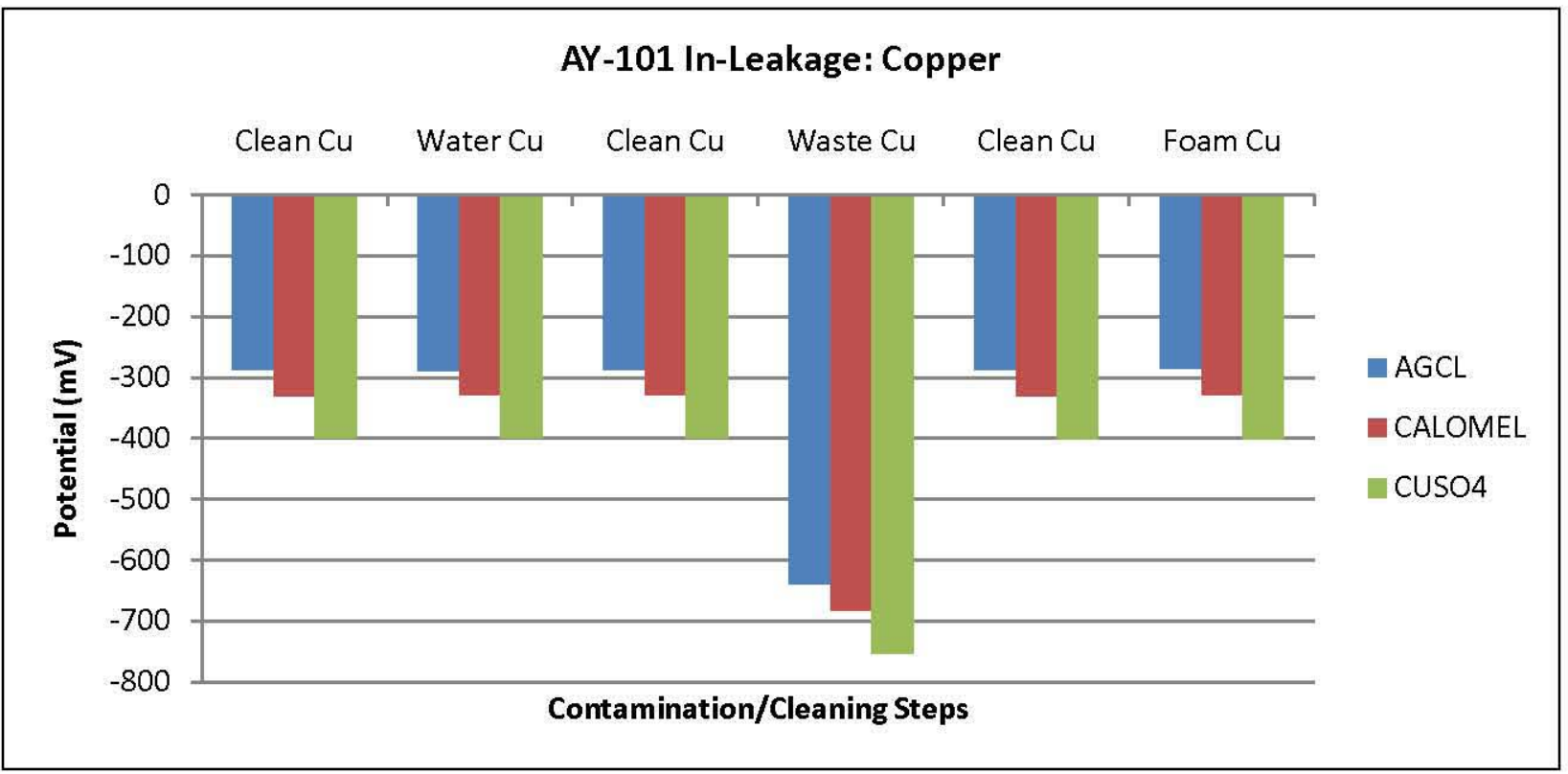

Figure 3-5. 241-AN-107 Copper Electrode Wetting. Potential of the Copper Secondary Reference Electrode is Measured with Respect to the Reference MPCMS-Style Primary Reference Electrodes at Room Temperature in 241-AN-107 Waste Simulant. Groups Represent Individual Contamination Steps.

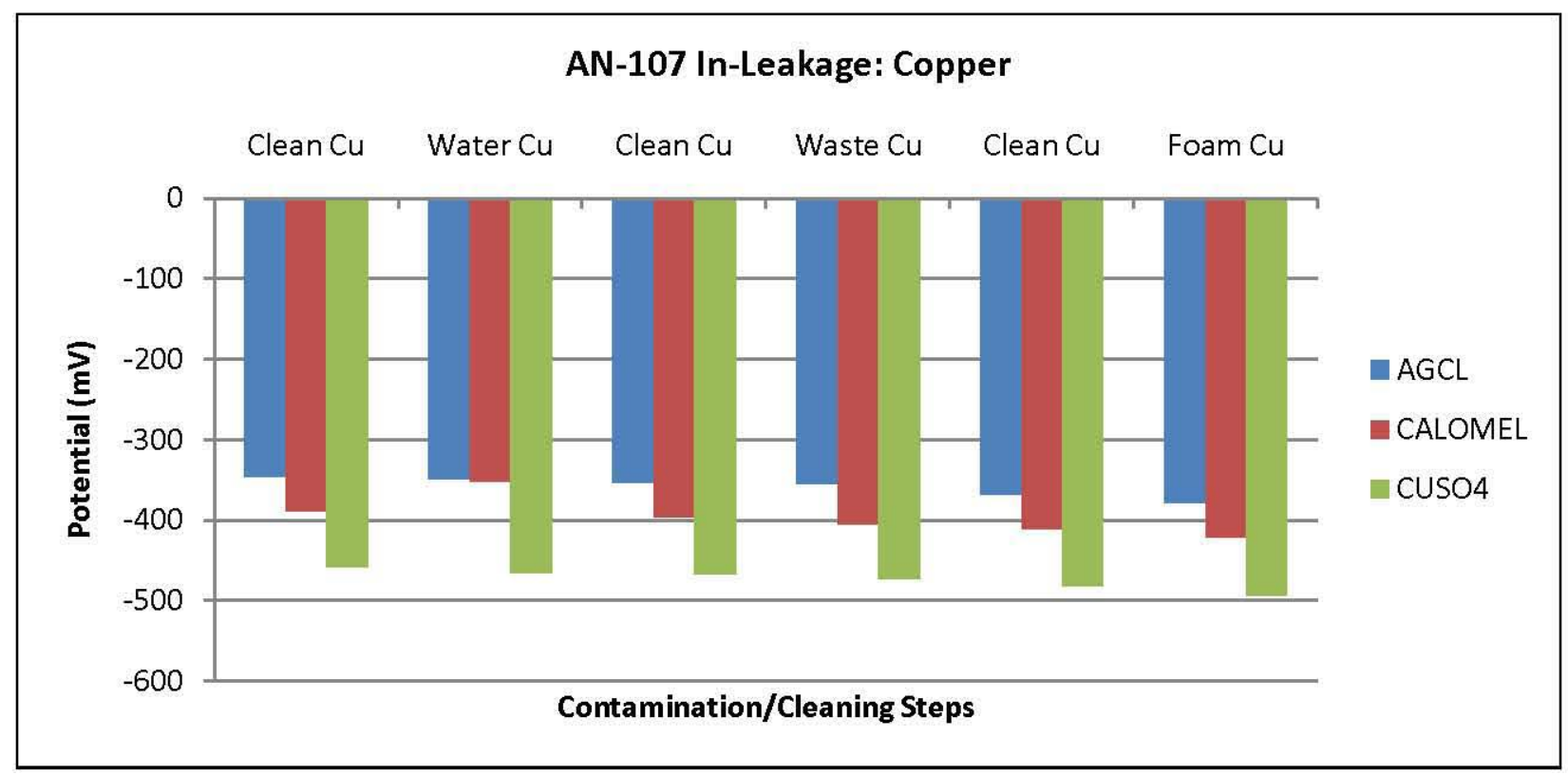


Figure 3-6. 241-AY-101 Silver Electrode Wetting. Potential of the Silver Secondary Reference Electrode is Measured with Respect to the Reference MPCMS-Style Primary Reference Electrodes at Room Temperature in 241-AY-101 Waste Simulant. Groups Represent Individual Contamination Steps.

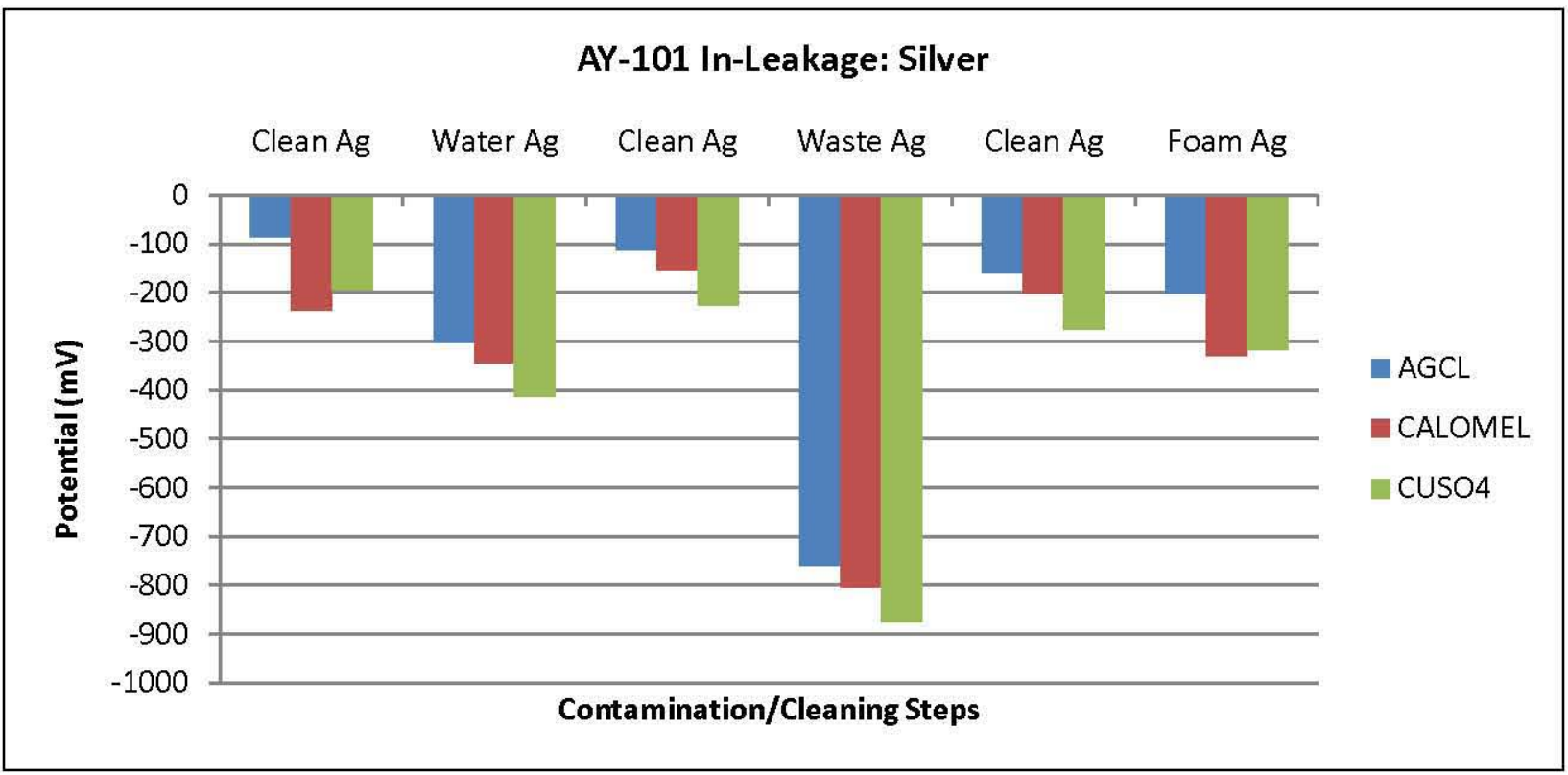

Figure 3-7. 241-AN-107 Silver Electrode Wetting. Potential of the Silver Secondary Reference Electrode is Measured with Respect to the Reference MPCMS-Style Primary Reference Electrodes at Room Temperature in 241-AN-107 Waste Simulant. Groups Represent Individual Contamination Steps.

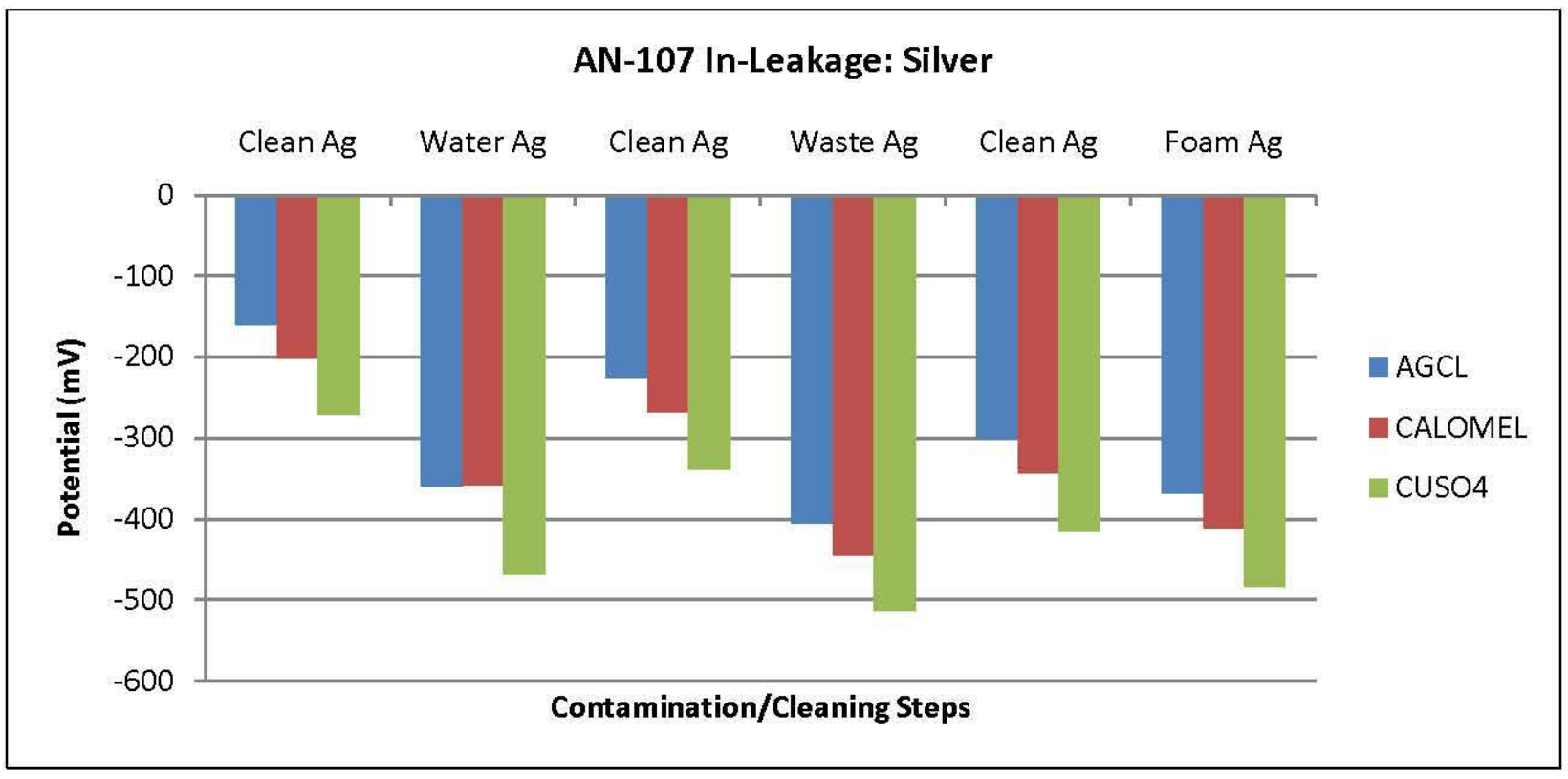


Figure 3-8. 241-AY-101 Tank Material Electrode Wetting. Potential of the AAR TC128 Secondary Reference Electrode is Measured with Respect to the Reference MPCMS-Style Primary Reference Electrodes at Room Temperature in 241-AY-101 Waste Simulant. Groups Represent Individual Contamination Steps.

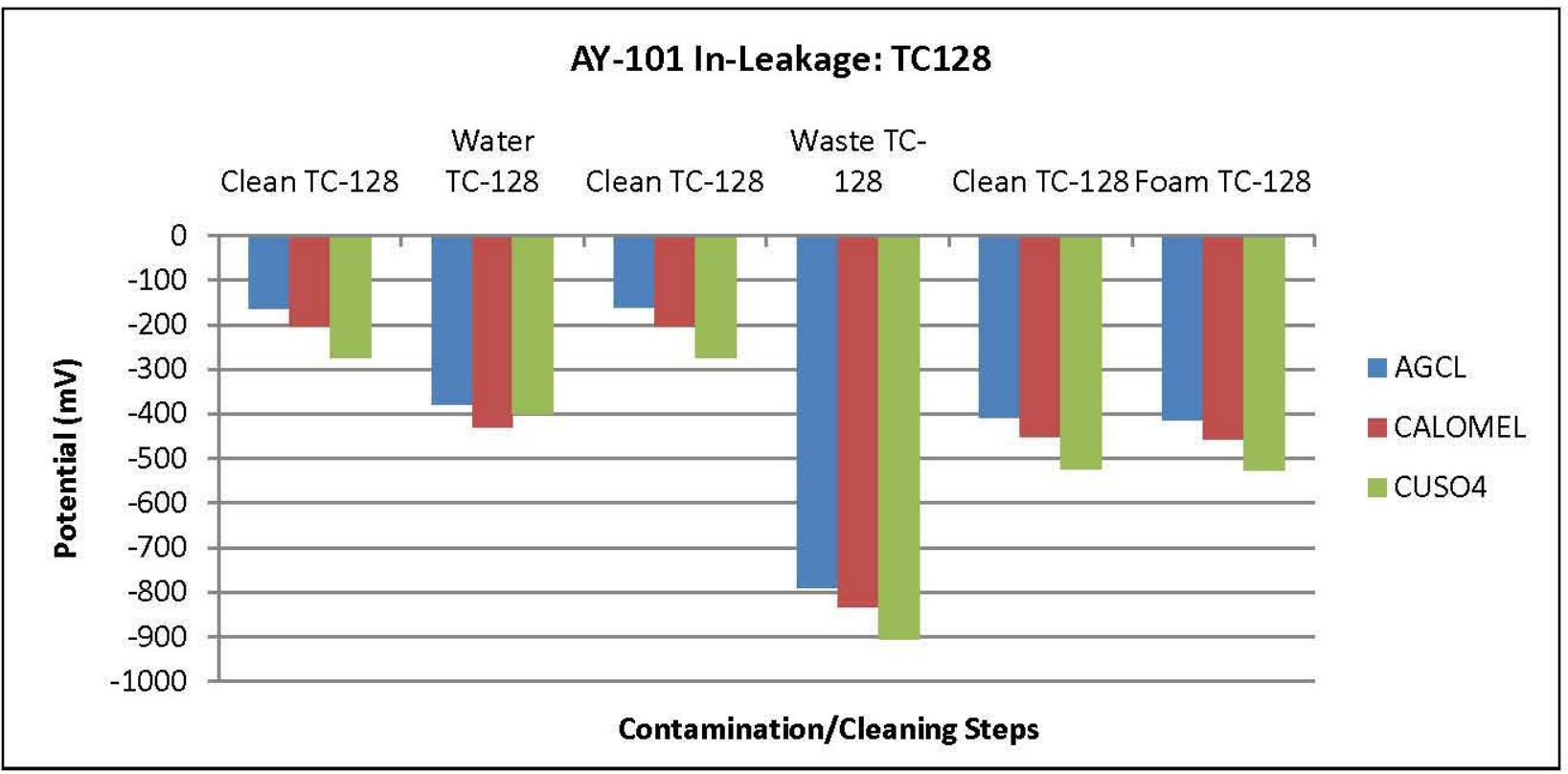


Figure 3-9. 241-AN-107 Tank Material Electrode Wetting. Potential of the ASTM A537 CL1 Secondary Reference Electrode is Measured with Respect to the reference MPCMSStyle Primary Reference Electrodes at Room Temperature in 241-AN-107 Waste Simulant. Groups Represent Individual Contamination Steps.

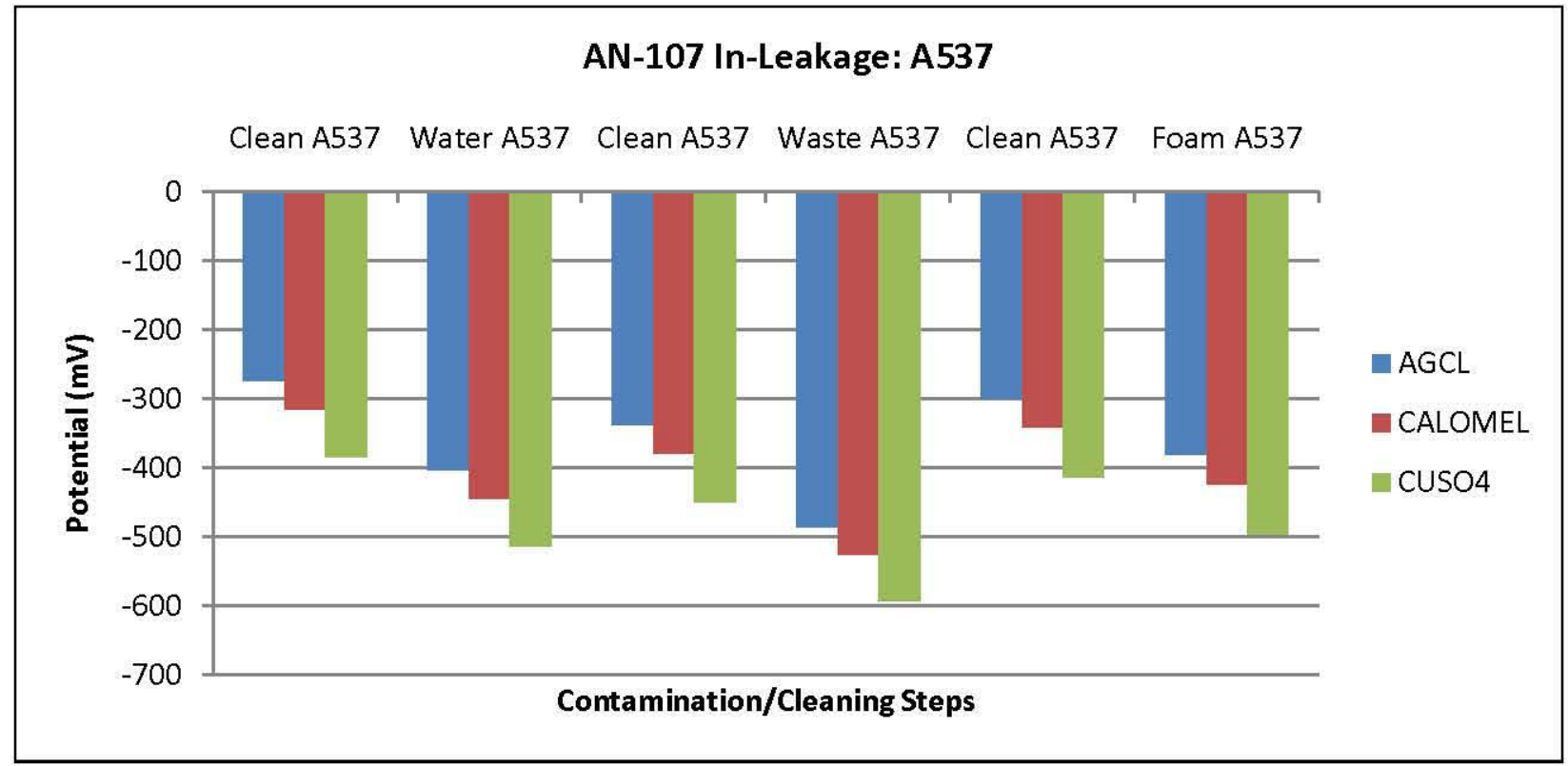

\subsection{TANK MATERIAL AND SECONDARY REFERENCE ELECTRODE DISCUSSION}

Note that the potentials measured from each "clean" electrode in between wetting steps (i.e., the "clean" measurement between wetting with water and wetting with waste simulant) are not always the same. While great efforts were made to clean and dry each electrode in between wetting steps, it was very difficult to return the electrodes to their pre-wetted condition, particularly after the tests using waste simulant. It is for this reason that new baseline measurements were taken after each electrode cleaning operation.

\subsubsection{1-AY-101 Test Cell}

Potential differences for each wetting step measured for each secondary reference electrode in the 241-AY-101 test cell with respect to each MPCMS primary reference electrode held at $25^{\circ} \mathrm{C}$ are documented in Table 3-2. 
Table 3-2. Potential Difference Measured for the Secondary Reference Electrodes with Respect to Each Reference MPCMS Primary Reference Electrode Held at $25^{\circ} \mathrm{C}$ in the 241 AY-101 Test Cell.

\begin{tabular}{|c|c|c|c|}
\hline & $\begin{array}{c}\text { Clean Ni and Water Ni } \\
{[\mathrm{mV}]}\end{array}$ & $\begin{array}{c}\text { Clean Ni and Waste Ni } \\
{[\mathrm{mV}]}\end{array}$ & $\begin{array}{c}\text { Clean } \mathrm{Ni} \text { and Foam Ni } \\
{[\mathrm{mV}]}\end{array}$ \\
\hline $\mathrm{AgCl}$ & -232.9 & -594.5 & -176.9 \\
\hline Calomel & -234.1 & -596.2 & -163.8 \\
\hline \multirow[t]{2}{*}{$\mathrm{CuSO}_{4}$} & -234.5 & -596.5 & -169.8 \\
\hline & $\begin{array}{c}\text { Clean } \mathrm{Cu} \text { and Water } \mathrm{Cu} \\
{[\mathrm{mV}]}\end{array}$ & $\begin{array}{c}\text { Clean } \mathrm{Cu} \text { and Waste } \mathrm{Cu} \\
{[\mathrm{mV}]}\end{array}$ & $\begin{array}{l}\text { Clean } \mathrm{Cu} \text { and Foam } \mathrm{Cu} \\
{[\mathrm{mV}]}\end{array}$ \\
\hline $\mathrm{AgCl}$ & -2.4 & -352.8 & 2.3 \\
\hline Calomel & 1 & -354.3 & 1.4 \\
\hline \multirow[t]{2}{*}{$\mathrm{CuSO}_{4}$} & -0.7 & -354.3 & 1.2 \\
\hline & $\begin{array}{c}\text { Clean Ag and Water Ag } \\
{[[\mathrm{mV}]}\end{array}$ & $\begin{array}{c}\text { Clean Ag and Waste Ag } \\
{[\mathrm{mV}]}\end{array}$ & $\begin{array}{l}\text { Clean Ag and Foam Ag } \\
{[[\mathrm{mV}]}\end{array}$ \\
\hline AgCl & -215.8 & -648.3 & -42.2 \\
\hline Calomel & -106.5 & -649.9 & -128.2 \\
\hline \multirow[t]{2}{*}{$\mathrm{CuSO}_{4}$} & -217 & -649.5 & -42.6 \\
\hline & $\begin{array}{l}\text { Clean AAR TC128 and } \\
\text { Water AAR TC128 [mV] }\end{array}$ & $\begin{array}{c}\text { Clean AAR TC128 and } \\
\text { Waste AAR TC128 } \\
{[\mathrm{mV}]}\end{array}$ & $\begin{array}{l}\text { Clean AAR TC128 and } \\
\text { Foam AAR TC128 }[\mathrm{mV}]\end{array}$ \\
\hline AgCl & -216.9 & -629.7 & -7.6 \\
\hline Calomel & -225.8 & -630.9 & -6.8 \\
\hline $\mathrm{CuSO}_{4}$ & -127.4 & -630.8 & -2.3 \\
\hline
\end{tabular}

\subsubsection{Nickel}

Figure 3-2 shows the measured potentials of the nickel secondary reference electrode in the 241-AY-101 test cell. After wetting with water, the potential of the nickel electrode dropped approximately $230 \mathrm{mV}$ with respect to all three MPCMS primary reference electrodes held at $25^{\circ} \mathrm{C}$. When wetted with $241-\mathrm{AY}-101$ waste simulant, the potential of the nickel electrode decreased approximately $595 \mathrm{mV}$ with respect to all three MPCMS primary reference electrodes held at $25^{\circ} \mathrm{C}$. The potential of the nickel electrode decreased approximately $170 \mathrm{mV}$ when wetted with Foam Part B Component.

\subsubsection{Copper}

Figure 3-4 shows the measured potentials of the copper secondary reference electrode in the 241-AY-101 test cell. After wetting with water, the potential of the copper electrode remained relatively constant with respect to all three MPCMS primary reference electrodes held at $25^{\circ} \mathrm{C}$. When wetted with 241-AY-101 waste simulant, the potential of the copper electrode decreased approximately $350 \mathrm{mV}$ with respect to all three MPCMS primary reference electrodes held at 
$25^{\circ} \mathrm{C}$. The potential of the copper electrode was relatively unaffected when wetted with Foam Part B Component.

\subsubsection{Silver}

Figure 3-6 shows the measured potentials of the copper secondary reference electrode in the 241-AY-101 test cell. After wetting with water, the potential of the silver electrode decreased by about $215 \mathrm{mV}$ with respect to the $\mathrm{Ag} / \mathrm{AgCl}$ and $\mathrm{Cu} / \mathrm{CuSO}_{4}$ electrodes, held at $25^{\circ} \mathrm{C}$. The potential of the silver electrode with respect to the calomel electrode held at $25^{\circ} \mathrm{C}$ decreased only about $100 \mathrm{mV}$. When wetted with 241-AY-101 waste simulant, the potential of the silver electrode decreased approximately $650 \mathrm{mV}$ with respect to all three MPCMS primary reference electrodes held at $25^{\circ} \mathrm{C}$. The potential of the silver electrode decreased by about $40 \mathrm{mV}$ with respect to the $\mathrm{Ag} / \mathrm{AgCl}$ and $\mathrm{Cu} / \mathrm{CuSO}_{4}$ electrodes, and about $130 \mathrm{mV}$ with respect to the calomel electrode, when wetted with Foam Part B Component.

Waste simulant had the greatest affect on the measured potential of the silver secondary reference electrode. When wetted with both water and foam component $\mathrm{B}$, the relationship between the silver electrode and the MPCMS-style calomel electrode held at $25^{\circ} \mathrm{C}$ seems to be erratic. The potential of each secondary reference electrode changes approximately equally with respect to every MPCMS-style primary reference electrode held at $25^{\circ} \mathrm{C}$. The relationship between the silver electrode and the MPCMS-style calomel electrode at $25^{\circ} \mathrm{C}$ does not follow this trend.

\subsubsection{AAR TC128}

Figure 3-8 shows the measured potentials of the AAR TC128 tank material electrode in the 241-AY-101 test cell. After wetting with water, the potential of the AAR TC128 electrode decreased by about $220 \mathrm{mV}$ with respect to the MPCMS-style $\mathrm{Ag} / \mathrm{AgCl}$ and calomel electrodes, held at $25^{\circ} \mathrm{C}$. The potential of the AAR TC128 electrode with respect to the MPCMS-style $\mathrm{Cu} / \mathrm{CuSO}_{4}$ electrode held at $25^{\circ} \mathrm{C}$ decreased only about $130 \mathrm{mV}$. When wetted with $241-\mathrm{AY}-$ 101 waste simulant, the potential of the AAR TC128 electrode decreased approximately $630 \mathrm{mV}$ with respect to all three MPCMS-style primary reference electrodes held at $25^{\circ} \mathrm{C}$. Lastly, the potential of the AAR TC128 electrode decreased by about $5 \mathrm{mV}$ with respect all three MPCMSstyle primary reference electrodes held at $25^{\circ} \mathrm{C}$.

When wetted with water and foam, the relationship between the AAR TC128 electrode and the MPCMS-style $\mathrm{Cu} / \mathrm{CuSO}_{4}$ electrode held at $25^{\circ} \mathrm{C}$ seems to be inconsistent. The potential of each secondary reference electrode changes approximately equally with respect to every primary reference electrode held at $25^{\circ} \mathrm{C}$. The relationship between the AAR TC128 electrode and the $\mathrm{Cu} / \mathrm{CuSO}_{4}$ electrode does not follow this trend.

\subsubsection{1-AN-107 Test Cell}

Potential differences for each wetting step measured for each secondary reference electrode in the 241-AN-107 test cell with respect to each MPCMS primary reference electrode held at $25^{\circ} \mathrm{C}$ are documented in Table 3-3. 
Table 3-3. Potential Difference Measured for the Secondary Reference Electrodes with Respect to Each Reference MPCMS Primary Reference Electrode Held at $25^{\circ} \mathrm{C}$ in the 241 AN-107 Test Cell.

\begin{tabular}{|c|c|c|c|}
\hline & $\begin{array}{l}\text { Clean } \mathrm{Ni} \text { and Water } \mathrm{Ni} \\
{[\mathrm{mV}]}\end{array}$ & $\begin{array}{l}\text { Clean Ni and Waste Ni } \\
{[\mathrm{mV}]}\end{array}$ & $\begin{array}{l}\text { Clean } \mathrm{Ni} \text { and Foam Ni } \\
{[\mathrm{mV}]}\end{array}$ \\
\hline AgCl & -40.9 & -163 & -68.1 \\
\hline Calomel & -41 & -161 & -68.5 \\
\hline \multirow[t]{2}{*}{$\mathrm{CuSO}_{4}$} & -41.6 & -157.5 & -68.4 \\
\hline & $\begin{array}{l}\text { Clean } \mathrm{Cu} \text { and Water } \mathrm{Cu} \\
{[\mathrm{mV}]}\end{array}$ & $\begin{array}{l}\text { Clean } \mathrm{Cu} \text { and Waste } \mathrm{Cu} \\
{[\mathrm{mV}]}\end{array}$ & $\begin{array}{c}\text { Clean } \mathrm{Cu} \text { and Foam } \mathrm{Cu} \\
{[\mathrm{mV}]}\end{array}$ \\
\hline AgCl & -2.7 & -1.5 & -10.5 \\
\hline Calomel & 36.4 & -9.2 & -10.8 \\
\hline \multirow[t]{2}{*}{$\mathrm{CuSO}_{4}$} & -8.6 & -5.7 & -10.8 \\
\hline & $\begin{array}{l}\text { Clean Ag and Water Ag } \\
{[\mathrm{mV}]}\end{array}$ & $\begin{array}{l}\text { Clean Ag and Waste Ag } \\
{[\mathrm{mV}]}\end{array}$ & $\begin{array}{l}\text { Clean Ag and Foam Ag } \\
{[\mathrm{mV}]}\end{array}$ \\
\hline AgCl & -199.2 & -179.3 & -67.4 \\
\hline Calomel & -156.6 & -177.4 & -67.6 \\
\hline \multirow[t]{2}{*}{$\mathrm{CuSO}_{4}$} & -198.7 & -173.7 & -67.9 \\
\hline & $\begin{array}{c}\text { Clean ASTM A537 CL1 } \\
\text { and Water ASTM A537 } \\
\text { CL1 [mV] }\end{array}$ & $\begin{array}{c}\text { Clean ASTM A537 } \\
\text { CL1and Waste ASTM } \\
\text { A537 CL1 [mV] }\end{array}$ & $\begin{array}{c}\text { Clean ASTM A537 CL1 } \\
\text { and Foam ASTM A537 } \\
\text { CL1 [mV] }\end{array}$ \\
\hline AgCl & -128.1 & -148.7 & -82.2 \\
\hline Calomel & -129.6 & -145.2 & -82.8 \\
\hline $\mathrm{CuSO}_{4}$ & -130.2 & -141.6 & -83.1 \\
\hline
\end{tabular}

\subsubsection{Nickel}

Figure 3-3 shows the measured potentials of the nickel secondary reference electrode in the 241-AN-107 test cell. After wetting with water, the potential of the nickel electrode dropped approximately $40 \mathrm{mV}$ with respect to all three MPCMS-style primary reference electrodes held at $25^{\circ} \mathrm{C}$. When wetted with $241-\mathrm{AN}-107$ waste simulant, the potential of the nickel electrode decreased approximately $160 \mathrm{mV}$ with respect to all three MPCMS-style primary reference electrodes held at $25^{\circ} \mathrm{C}$. Lastly, the potential of the nickel electrode decreased approximately $68 \mathrm{mV}$ when wetted with Foam Part B Component.

\subsubsection{Copper}

Figure 3-5 shows the measured potentials of the copper secondary reference electrode in the 241-AN-107 test cell. After wetting with water, the potential of the copper electrode decreased by approximately $5 \mathrm{mV}$ with respect to the MPCMS-style $\mathrm{Ag} / \mathrm{AgCl}$ and $\mathrm{Cu} / \mathrm{CuSO}_{4}$ reference electrodes held at $25^{\circ} \mathrm{C}$. The potential of the copper electrode increased by $36 \mathrm{mV}$ with respect to the calomel reference electrode held at $25^{\circ} \mathrm{C}$. When wetted with $241-\mathrm{AN}-107$ waste simulant, the potential of the copper electrode decreased approximately $5 \mathrm{mV}$ with respect to all three 
MPCMS primary reference electrodes held at $25^{\circ} \mathrm{C}$. Lastly, the potential of the copper electrode decreased by about $10 \mathrm{mV}$ with respect to all three MPCMS-style reference electrodes held at $25^{\circ} \mathrm{C}$ when wetted with Foam Part B Component.

The relationship between the copper electrode and the MPCMS-style calomel electrode held at $25^{\circ} \mathrm{C}$ is erratic when wetted with water. The potential of each secondary reference electrode seems to change approximately equally with respect to every MPCMS-style primary reference electrode held at $25^{\circ} \mathrm{C}$. The relationship between the copper electrode and the MPCMS-style calomel electrode does not follow this trend.

Wetting both with water and waste simulant seemed to have little effect on the measured potential of the copper electrode. Foam Part B Component did affect the measured potential slightly; however the copper electrode in the 241-AN-107 test cell was relatively unaffected by the wetting process.

\subsubsection{Silver}

Figure 3-7 shows the measured potentials of the silver secondary reference electrode in the 241-AN-107 test cell. After wetting with water, the potential of the silver electrode decreased by about $200 \mathrm{mV}$ with respect to the MPCMS-style $\mathrm{Ag} / \mathrm{AgCl}$ and $\mathrm{Cu} / \mathrm{CuSO}_{4}$ electrodes, held at $25^{\circ} \mathrm{C}$. The potential of the silver electrode with respect to the MPCMS-style calomel electrode held at $25^{\circ} \mathrm{C}$ decreased only about $155 \mathrm{mV}$. When the electrode was wetted with 241-AN-107 waste simulant, the potential decreased approximately $175 \mathrm{mV}$ with respect to all three MPCMSstyle primary reference electrodes held at $25^{\circ} \mathrm{C}$. Lastly, the potential of the silver electrode decreased by about $68 \mathrm{mV}$ with respect to all three MPCMS-style primary reference electrodes held at $25^{\circ} \mathrm{C}$ when wetted with Foam Part B Component.

Both water and waste simulant had a similar effect on the measured potential of the silver secondary reference electrode, decreasing the potential about $180 \mathrm{mV}$.

When wetted with water, the relationship between the silver electrode and the MPCMS-style calomel electrode held at $25^{\circ} \mathrm{C}$ is erratic. The potential of each secondary reference electrode seems to change approximately equally with respect to every MPCMS-style primary reference electrode held at $25^{\circ} \mathrm{C}$. The relationship between the silver electrode and the MPCMS-style calomel electrode does not follow this trend.

\subsubsection{ASTM A537 CL1}

Figure 3-8 shows the measured potentials of the ASTM A537 CL1 tank material electrode in the 241-AN-107 test cell. After wetting with water, the potential of the ASTM A537 CL1 electrode decreased by about $130 \mathrm{mV}$ with respect to all three MPCMS-style primary reference electrodes held at $25^{\circ} \mathrm{C}$. When wetted with $241-\mathrm{AN}-107$ waste simulant, the potential of the ASTM A537 CL1 electrode decreased approximately $145 \mathrm{mV}$ with respect to all three MPCMS-style primary reference electrodes held at $25^{\circ} \mathrm{C}$. Lastly, when wetted with Foam Part B Component, the potential of the ASTM A537 CL1 electrode decreased by about $83 \mathrm{mV}$ with respect to all three MPCMS-style primary reference electrodes held at $25^{\circ} \mathrm{C}$. 
Both water and waste simulant had a similar effect on the measured potential of the ASTM A537 CL1 secondary reference electrode, decreasing the potential about $135 \mathrm{mV}$.

\subsubsection{Equivalent Circuit}

Electrical diagrams offer a useful explanation to the behavior observed when the back of a reference electrode contained in a metallic housing is wetted with a conductive liquid. An electrical diagram of a secondary reference electrode in a liquid-filled MPCMS probe is shown in Figure 3-10 below.

\section{Figure 3-10. Electrical Schematic of a Secondary Reference Electrode in an In-Tank Probe with Waste In-Leakage.}

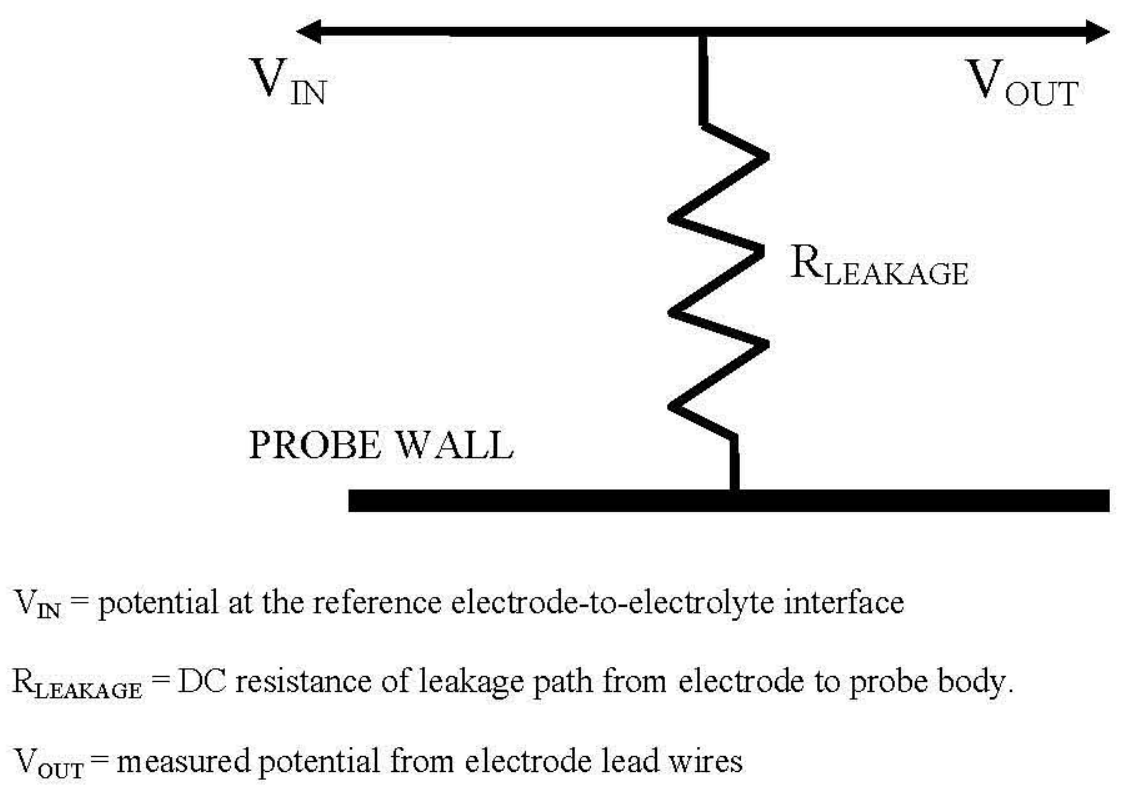

Under normal circumstances, secondary reference electrodes are electrically isolated from the probe body, therefore $\mathrm{R}_{\text {LEAKAGE }}$ can be considered to be infinite. However, should waste inleakage occur, $\mathrm{R}_{\mathrm{LEAKAGE}}$ will equal the inherent resistance of the liquid. As depicted in Figure $3-10$, this resistance will be formed between the electrode to the probe body.

The voltage potential at the electrode-tank waste interface $\left(\mathrm{V}_{\mathrm{IN}}\right)$ is typically measured by connecting a multimeter to a lead terminated to an electrode. The voltage measured at the electrode lead ( $\mathrm{V}_{\text {OUT }}$ ) is equal to $\mathrm{V}_{\mathrm{IN}}$.

If liquid in-leakage were to electrically connect an electrode to the probe body, as shown in Figure 3-10, current can flow from the electrode-to-electrolyte interface in two directions: to the electrode lead or to the probe body. Normally $\mathrm{V}_{\text {OUT }}$ should equal $\mathrm{V}_{\mathrm{IN}}$; however, if the in-leaked fluid were highly conductive, it would have some effect on $\mathrm{V}_{\text {OUT }}$ due to the impedance between the metal electrode and the conductive solution. When the voltage at the electrode lead (V $\left.\mathrm{V}_{\text {OUT }}\right)$ is measured against the voltage of the electrode housing, the resulting potential is equal to the true voltage potential at the electrode-tank waste interface $\left(\mathrm{V}_{\mathrm{IN}}\right)$. 
RPP-RPT-44463, Rev. 0

\subsection{PRIMARY REFERENCE ELECTRODE RESULTS}

NOTE: For the purposes of this discussion, the term "wetted" or "wetted electrode" indicates the presence of some form of liquid on the back of the electrode causing a short between the electrode and the metallic electrode housing.

The measured potentials for the wetted primary reference electrodes are presented in Figures 311 through 3-16. In each figure, the potential values for the electrode are grouped in order by contamination/cleaning steps as follows:

1. Initial potential, prior to wetting (e.g., Clean $\mathrm{Ag} / \mathrm{AgCl}$ ),

2. Potential after wetting with water (e.g., Water $\mathrm{Ag} / \mathrm{AgCl}$ ),

3. Potential after cleaning and drying after water test (e.g., Clean $\mathrm{Ag} / \mathrm{AgCl}$ ),

4. Potential after wetting with waste simulant (e.g., Waste $\mathrm{Ag} / \mathrm{AgCl}$ ),

5. Potential after cleaning and drying after waste simulant test (e.g., Clean $\mathrm{Ag} / \mathrm{AgCl}$ ), and

6. Potential after wetting with Foam Part B Component (e.g., Foam Ag/AgCl).

Due to the difference in structure of the primary reference electrodes from the secondary reference electrodes, the measured potentials of the primaries were expected to be affected differently than the secondary reference electrodes. All primary reference electrodes under test in the test cells were measured with respect to their corresponding reference MPCMS-style electrodes in the $25^{\circ} \mathrm{C}$ reference cell. The potentials of the $\mathrm{Ag} / \mathrm{AgCl}$, calomel, and $\mathrm{Cu} / \mathrm{CuSO}$ electrodes are represented in Figures 3-11 and 3-12, 3-13 and 3-14, and 3-15 and 3-16, respectively.

With few exceptions, the effect of each contamination step on the potential of the electrodes is similar to that observed for the metallic electrodes. In general, the waste simulant, when in contact with the back of the electrodes, resulted in a much larger negative shift in potential than the other contaminants produced. Interestingly, the 241-AY-101 simulant produced much more significant potential shifts than the 241-AN-107 simulant. The water and foam component contamination steps result in similar potential shifts for each electrode.

Due to the large amount of data collected in the test program, it is not possible or necessary to show all data to summarize the general results of testing. Instead, selected data representative of the results of testing are presented below in an effort to summarize the general results of testing. Additional test data are shown in Appendix E should the reader wish to investigate the results of testing in greater detail. 
Figure 3-11. Measured Potential of the Ag/AgCl Electrode with Respect to the Reference MPCMS-Style Primary Reference Electrodes at Room Temperature in 241-AY-101 Waste Simulant. Groups Represent Individual Contamination Steps.

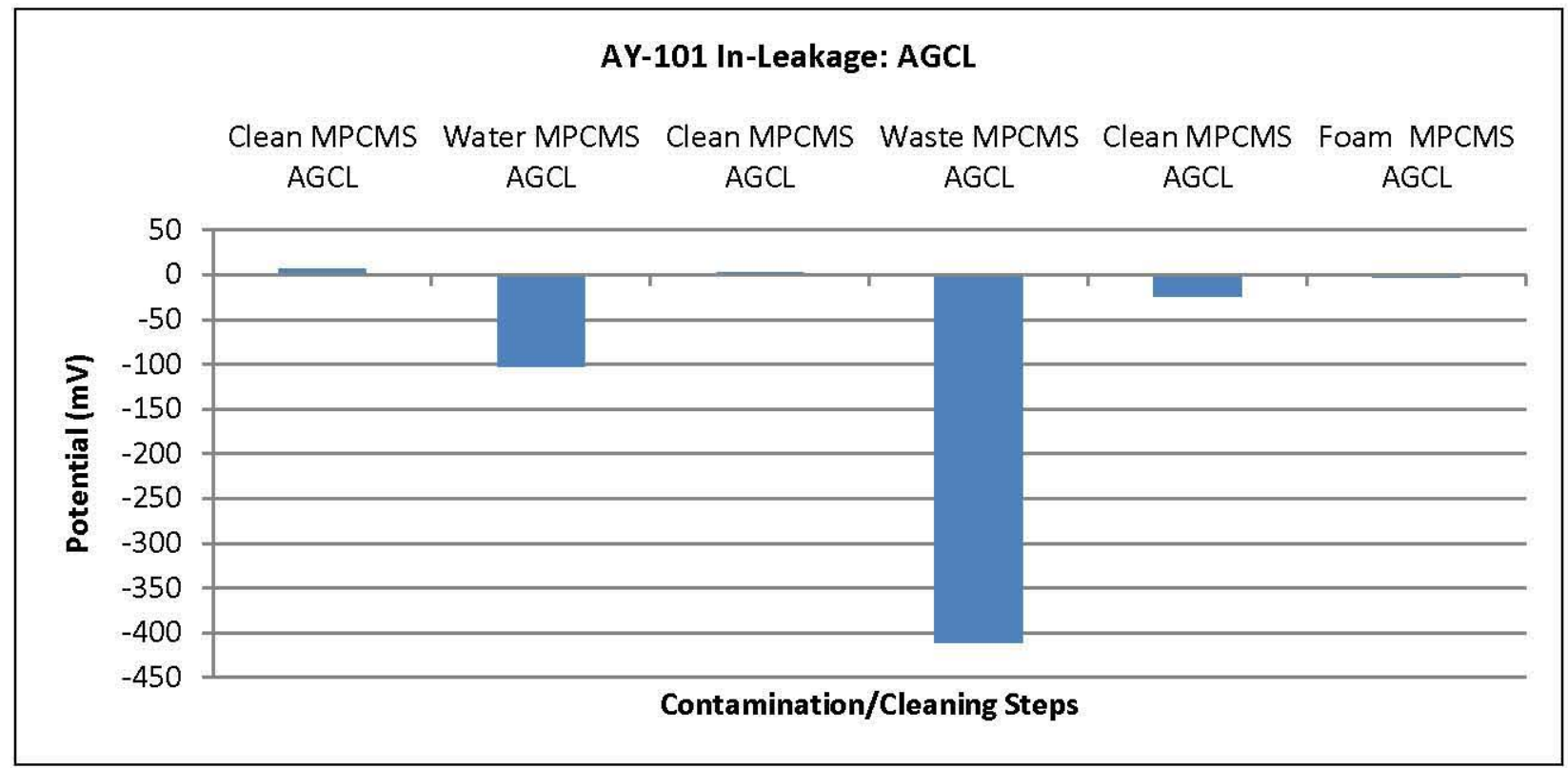

Figure 3-12. Measured Potential of the Ag/AgCl Electrode with Respect To the Reference MPCMS-Style Primary Reference Electrodes at Room Temperature in 241-AN-107 Waste Simulant. Groups Represent Individual Contamination Steps.

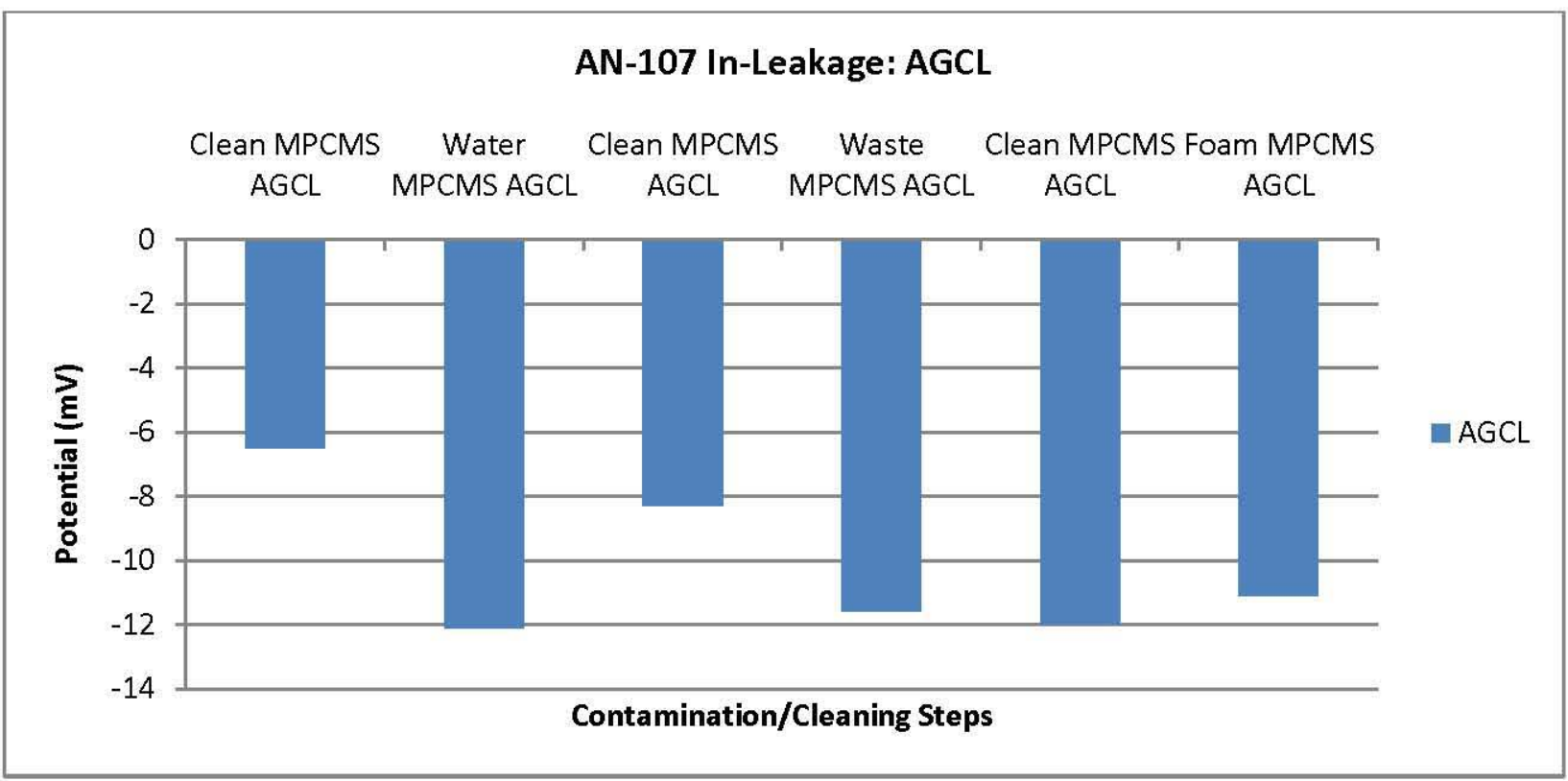


Figure 3-13. Measured Potential of the Calomel Electrode with Respect to the Reference MPCMS-Style Primary Reference Electrodes at Room Temperature in 241-AY-101 Waste Simulant. Groups Represent Individual Contamination Steps.

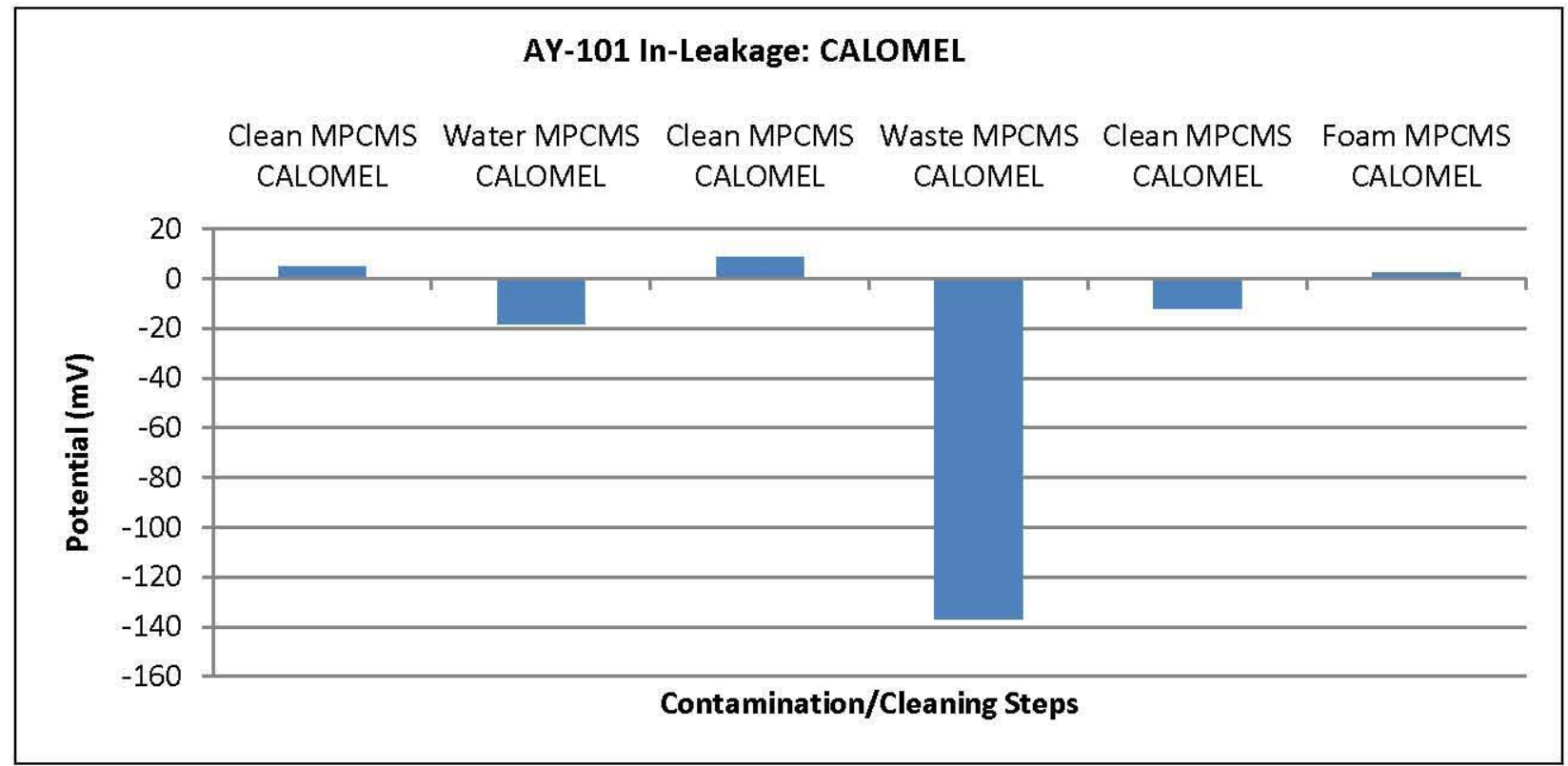

Figure 3-14. Measured Potential of the Calomel Electrode with Respect to the Reference MPCMS-Style Primary Reference Electrodes at Room Temperature in 241-AN-107 Waste Simulant. Groups Represent Individual Contamination Steps.

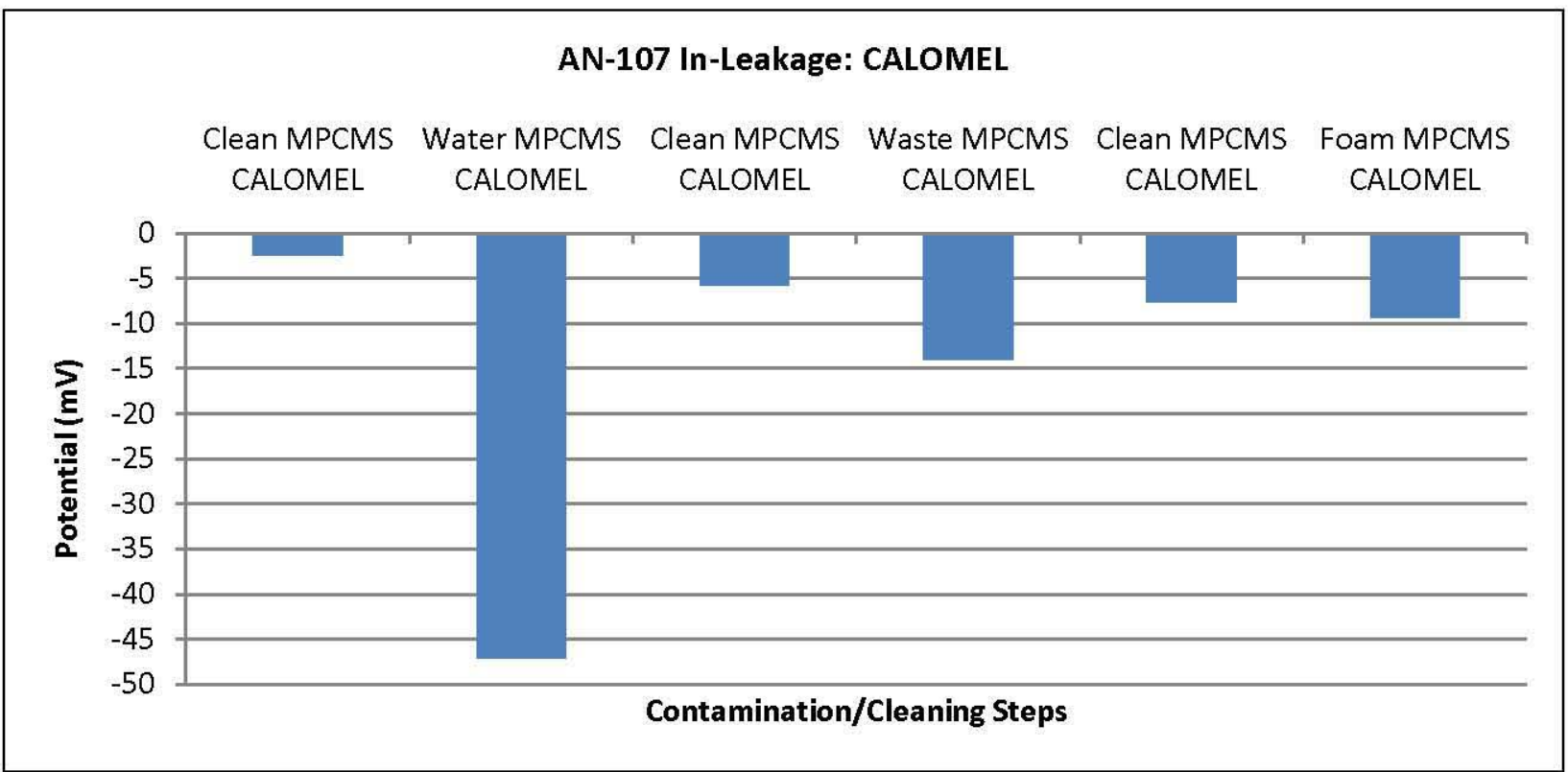


Figure 3-15. Measured Potential of the $\mathrm{Cu} / \mathrm{CuSO}_{4}$ Electrode with Respect to the Reference MPCMS-Style Primary Reference Electrodes at Room Temperature in 241-AY-101 Waste Simulant. Groups Represent Individual Contamination Steps.

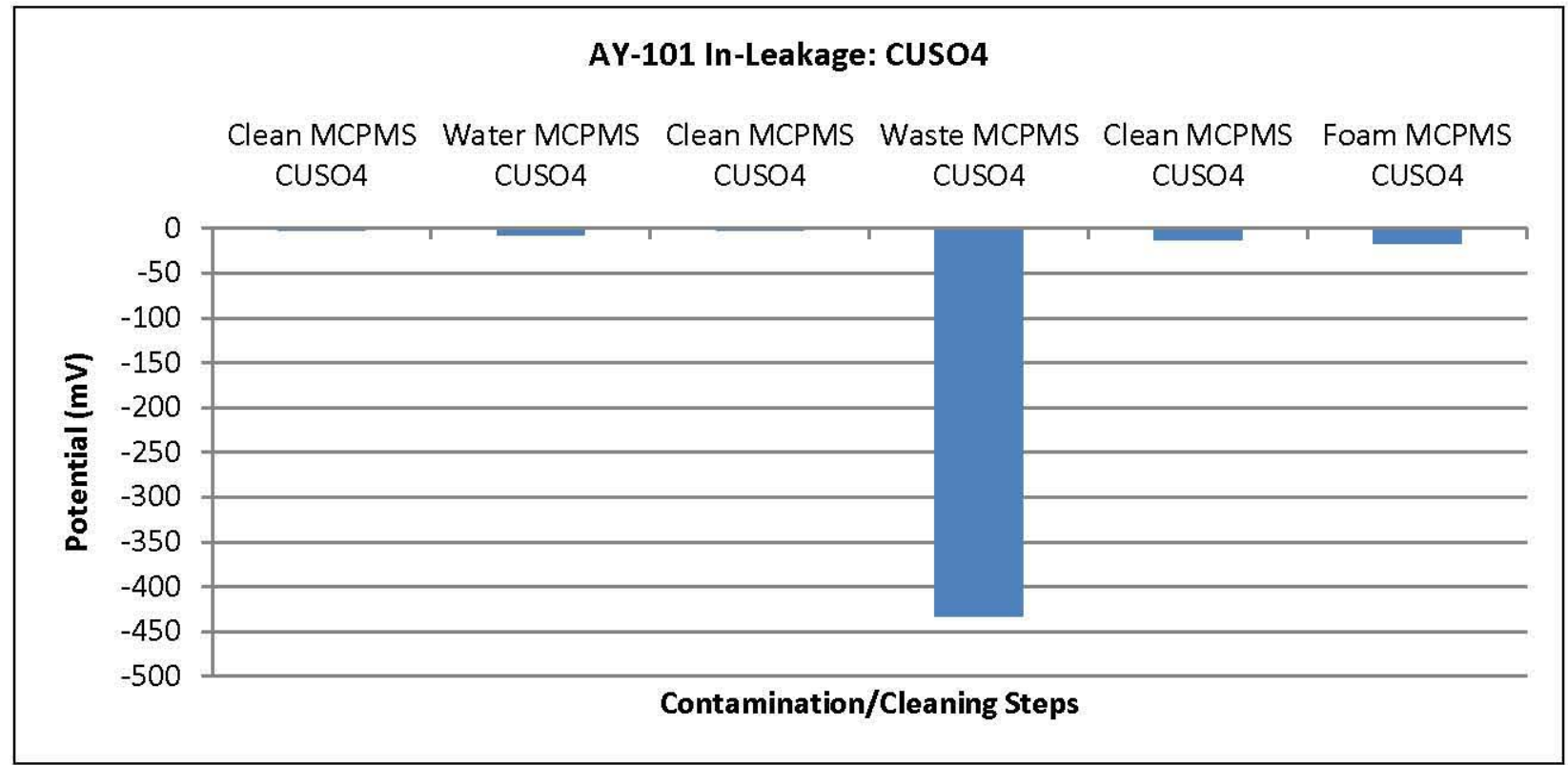

Figure 3-16. Measured Potential of the $\mathrm{Cu} / \mathrm{CuSO}_{4}$ Electrode with Respect to the Reference MPCMS-Style Primary Reference Electrodes at Room Temperature in 241-AN-107 Waste Simulant. Groups Represent Individual Contamination Steps.

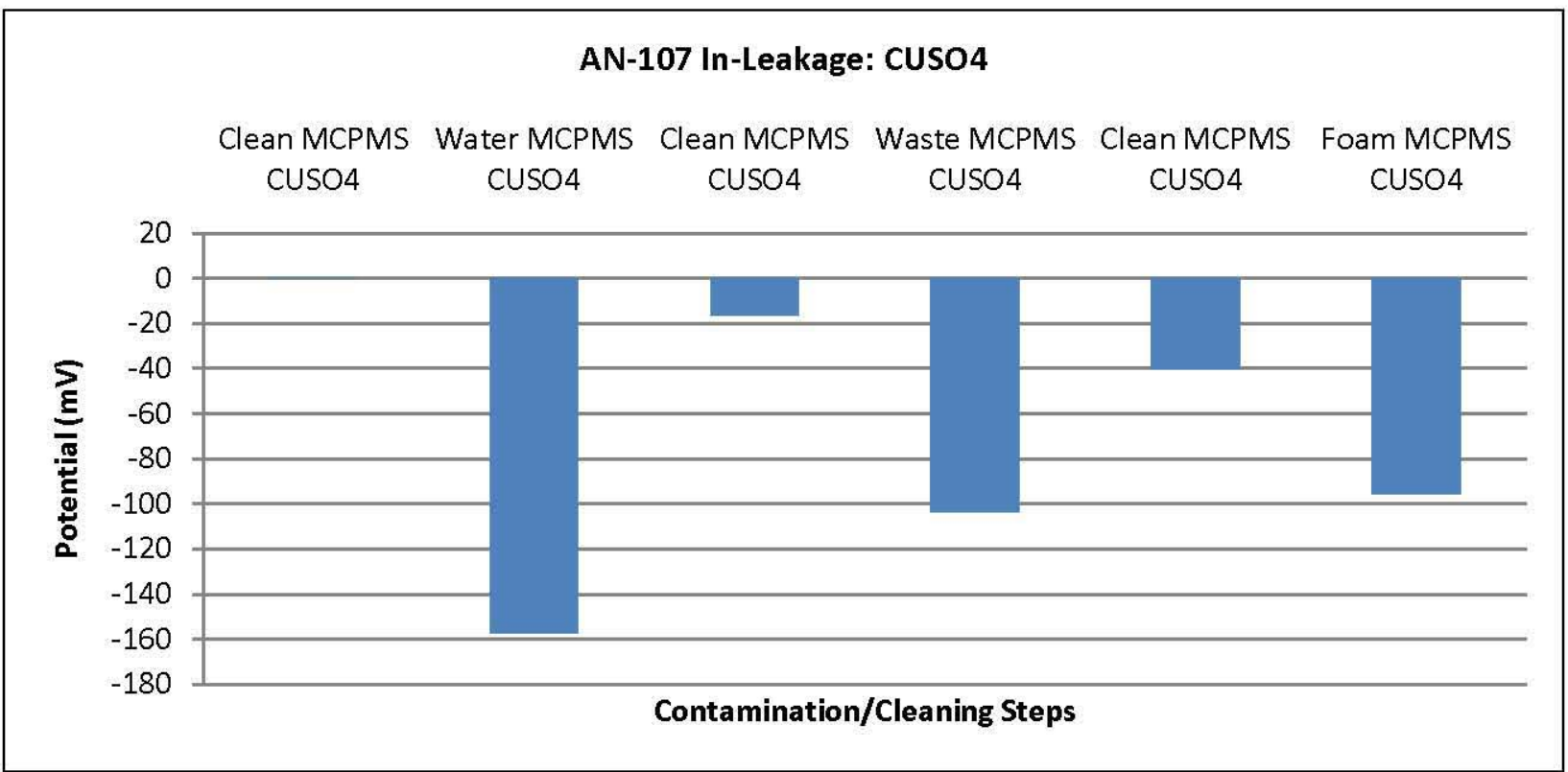




\subsection{PRIMARY REFERENCE ELECTRODE DISCUSSION}

Note that the potentials measured from each "clean" electrode in between wetting steps (i.e., the "clean" measurement between wetting with water and wetting with waste simulant) are not always the same. While great efforts were made to clean and dry each electrode in between wetting steps, it was very difficult to return the electrodes to their pre-wetted condition, particularly after the tests using waste simulant. It is for this reason that new baseline measurements were made after each electrode cleaning operation.

\subsubsection{1-AY-101 Test Cell}

Potential differences for each wetting step measured for each MPCMS primary reference electrode in the 241-AY-101 test cell with respect to each MPCMS primary reference electrode held at $25^{\circ} \mathrm{C}$ are documented in Table 3-4.

Table 3-4. Potential Difference Measured for the Primary Reference Electrodes Under Test with Respect to Respective MPCMS Primary Reference Electrode Held at $25^{\circ} \mathrm{C}$ in the 241-AY-101 Test Cell.

\begin{tabular}{|c|c|c|c|}
\hline & $\begin{array}{c}\text { Clean } \mathrm{Ag} / \mathrm{AgCl} \text { and Water } \\
\mathrm{Ag} / \mathrm{AgCl}[\mathrm{mV}]\end{array}$ & $\begin{array}{c}\text { Clean } \mathrm{Ag} / \mathrm{AgCl} \text { and Waste } \\
\mathrm{Ag} / \mathrm{AgCl}[\mathrm{mV}]\end{array}$ & $\begin{array}{c}\text { Clean } \mathrm{Ag} / \mathrm{AgCl} \text { and Foam } \\
\mathrm{Ag} / \mathrm{AgCl}[\mathrm{mV}]\end{array}$ \\
\hline \multirow[t]{2}{*}{$\mathrm{Ag} / \mathrm{AgCl}$} & -109 & -413.7 & 21.2 \\
\hline & $\begin{array}{c}\text { Clean Calomel and Water } \\
\text { Calomel [mV] }\end{array}$ & $\begin{array}{c}\text { Clean Calomel and Waste } \\
\text { Calomel }[\mathrm{mV}]\end{array}$ & $\begin{array}{c}\text { Clean Calomel and Foam } \\
\text { Calomel }[\mathrm{mV}]\end{array}$ \\
\hline \multirow[t]{2}{*}{ Calomel } & 13 & -145.3 & 14.4 \\
\hline & $\begin{array}{c}\text { Clean } \mathrm{Cu} / \mathrm{CuSO}_{4} \text { and } \\
\text { Water } \mathrm{Cu} / \mathrm{CuSO}_{4}[\mathrm{mV}]\end{array}$ & $\begin{array}{c}\text { Clean } \mathrm{Cu} / \mathrm{CuSO}_{4} \text { and } \\
\text { Waste } \mathrm{Cu} / \mathrm{CuSO}_{4}[\mathrm{mV}]\end{array}$ & 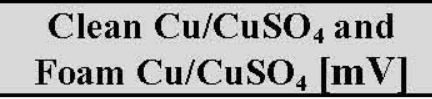 \\
\hline $\mathrm{Cu} / \mathrm{CuSO}_{4}$ & -5.07 & -431 & -3.5 \\
\hline
\end{tabular}

\subsubsection{Silver/Silver Chloride}

Figure 3-11 shows the measured potentials of the $\mathrm{Ag} / \mathrm{AgCl}$ primary reference electrode under test in the 241-AY-101 test cell with respect to the reference $\mathrm{Ag} / \mathrm{AgCl}$ primary reference electrode held at $25^{\circ} \mathrm{C}$. After wetting with water, the potential of the $\mathrm{Ag} / \mathrm{AgCl}$ primary reference electrode under test dropped $109 \mathrm{mV}$. When wetted with 241-AY-101 waste simulant, the potential of the $\mathrm{Ag} / \mathrm{AgCl}$ primary reference electrode under test decreased by $414 \mathrm{mV}$. The potential of the $\mathrm{Ag} / \mathrm{AgCl}$ primary reference electrode under test decreased $21 \mathrm{mV}$ when wetted with Foam Part B Component.

\subsubsection{Calomel}

Figure 3-13 shows the measured potentials of the calomel primary reference electrode under test in the 241-AY-101 test cell with respect to the reference calomel electrode held at $25^{\circ} \mathrm{C}$. After wetting with water, the potential of the calomel primary reference electrode under test increased by $13 \mathrm{mV}$. When wetted with $241-\mathrm{AY}-101$ waste simulant, the potential of the calomel primary 
reference electrode under test decreased $145 \mathrm{mV}$. The potential of the calomel primary reference electrode under test increased $14 \mathrm{mV}$ when wetted with Foam Part B Component.

\subsubsection{Copper/Copper Sulfate}

Figure 3-15 shows the measured potentials of the $\mathrm{Cu} / \mathrm{CuSO}_{4}$ primary reference electrode under test in the 241-AY-101 test cell with respect to the reference $\mathrm{Cu} / \mathrm{CuSO}_{4}$ primary reference electrode held at $25^{\circ} \mathrm{C}$. After wetting with water, the potential of the $\mathrm{Cu} / \mathrm{CuSO}_{4}$ primary reference electrode under test decreased by $5 \mathrm{mV}$. When wetted with 241-AY-101 waste simulant, the potential of the $\mathrm{Cu} / \mathrm{CuSO}_{4}$ primary reference electrode under test decreased $431 \mathrm{mV}$. The potential of the $\mathrm{Cu} / \mathrm{CuSO}_{4}$ primary reference electrode under test decreased $4 \mathrm{mV}$ when wetted with Foam Part B Component.

\subsubsection{1-AN-107 Test Cell}

Potential differences for each wetting step measured for each MPCMS primary reference electrode under test in the 241-AN-107 test cell with respect to each MPCMS primary reference electrode held at $25^{\circ} \mathrm{C}$ are documented in Table 3-5.

Table 3-5. Potential Differences Measured for the Primary Reference Electrodes Under Test with Respect to Respective MPCMS Primary Reference Electrode Held at $25^{\circ} \mathrm{C}$ in the 241-AN-107 Test Cell.

\begin{tabular}{|c|c|c|c|}
\hline & $\begin{array}{c}\text { Clean } \mathrm{Ag} / \mathrm{AgCl} \text { and Water } \\
\mathrm{Ag} / \mathrm{AgCl}[\mathrm{mV}]\end{array}$ & $\begin{array}{c}\text { Clean } \mathrm{Ag} / \mathrm{AgCl} \text { and Waste } \\
\mathrm{Ag} / \mathrm{AgCl}[\mathrm{mV}]\end{array}$ & $\begin{array}{c}\text { Clean } \mathrm{Ag} / \mathrm{AgCl} \text { and Foam } \\
\mathrm{Ag} / \mathrm{AgCl}[\mathrm{mV}]\end{array}$ \\
\hline \multirow[t]{2}{*}{$\mathrm{Ag} / \mathrm{AgCl}$} & -5.6 & -3.3 & 0.9 \\
\hline & $\begin{array}{c}\text { Clean Calomel and Water } \\
\text { Calomel [mV] }\end{array}$ & $\begin{array}{c}\text { Clean Calomel and Waste } \\
\text { Calomel [mV] }\end{array}$ & $\begin{array}{c}\text { Clean Calomel and Foam } \\
\text { Calomel [mV] }\end{array}$ \\
\hline \multirow[t]{2}{*}{ Calomel } & -44.6 & -8.2 & -1.8 \\
\hline & $\begin{array}{c}\text { Clean } \mathrm{Cu} / \mathrm{CuSO}_{4} \text { and } \\
\text { Water } \mathrm{Cu} / \mathrm{CuSO} \mathrm{SO}_{4}[\mathrm{mV}]\end{array}$ & $\begin{array}{c}\text { Clean } \mathrm{Cu} / \mathrm{CuSO}_{4} \text { and } \\
\text { Waste } \mathrm{Cu} / \mathrm{CuSO}_{4}[\mathrm{mV}]\end{array}$ & $\begin{array}{c}\text { Clean } \mathrm{Cu} / \mathrm{CuSO}_{4} \text { and } \\
\text { Foam } \mathrm{Cu} / \mathrm{CuSO}_{4}[\mathrm{mV}]\end{array}$ \\
\hline $\mathrm{Cu} / \mathrm{CuSO}_{4}$ & -157.6 & -86.9 & -55.7 \\
\hline
\end{tabular}

\subsubsection{Silver/Silver Chloride}

Figure 3-12 shows the measured potentials of the $\mathrm{Ag} / \mathrm{AgCl}$ primary reference electrode under test in the 241-AN-107 test cell with respect to the reference $\mathrm{Ag} / \mathrm{AgCl}$ primary reference electrode held at $25^{\circ} \mathrm{C}$. After wetting with water, the potential of the $\mathrm{Ag} / \mathrm{AgCl}$ primary reference electrode under test dropped $6 \mathrm{mV}$. When wetted with 241-AN-107 waste simulant, the potential of the $\mathrm{Ag} / \mathrm{AgCl}$ primary reference electrode under test decreased $3 \mathrm{mV}$. The potential of the $\mathrm{Ag} / \mathrm{AgCl}$ primary reference electrode under test increased $1 \mathrm{mV}$ when wetted with Foam Part B Component. 


\subsubsection{Calomel}

Figure 3-14 shows the measured potentials of the calomel primary reference electrode under test in the 241-AN-107 test cell with respect to the reference calomel primary reference electrode held at $25^{\circ} \mathrm{C}$. After wetting with water, the potential of the calomel primary reference electrode under test decreased by $45 \mathrm{mV}$. When wetted with $241-\mathrm{AN}-107$ waste simulant, the potential of the calomel primary reference electrode under test decreased $8.2 \mathrm{mV}$. The potential of the calomel primary reference electrode under test decreased $2 \mathrm{mV}$ when wetted with Foam Part B Component.

\subsubsection{Copper/Copper Sulfate}

Figure 3-16 shows the measured potentials of the $\mathrm{Cu} / \mathrm{CuSO}_{4}$ primary reference electrode under test in the 241-AN-107 test cell with respect to the reference $\mathrm{Cu} / \mathrm{CuSO}_{4}$ primary reference electrode held at $25^{\circ} \mathrm{C}$. After wetting with water, the potential of the $\mathrm{Cu} / \mathrm{CuSO}_{4}$ primary reference electrode under test decreased by $157 \mathrm{mV}$. When wetted with 241-AN-107 waste simulant, the potential of the $\mathrm{Cu} / \mathrm{CuSO}_{4}$ primary reference electrode under test decreased $87 \mathrm{mV}$. The potential of the $\mathrm{Cu} / \mathrm{CuSO}_{4}$ primary reference electrode decreased $56 \mathrm{mV}$ when wetted with Foam Part B Component.

\subsubsection{Equivalent Circuit}

Electrical diagrams offer a useful explanation to the behavior observed when the back of an electrode contained in a metallic housing is wetted with a conductive liquid. An electrical diagram of a primary reference electrode in a liquid-filled MPCMS probe body is shown in Figure 3-17.

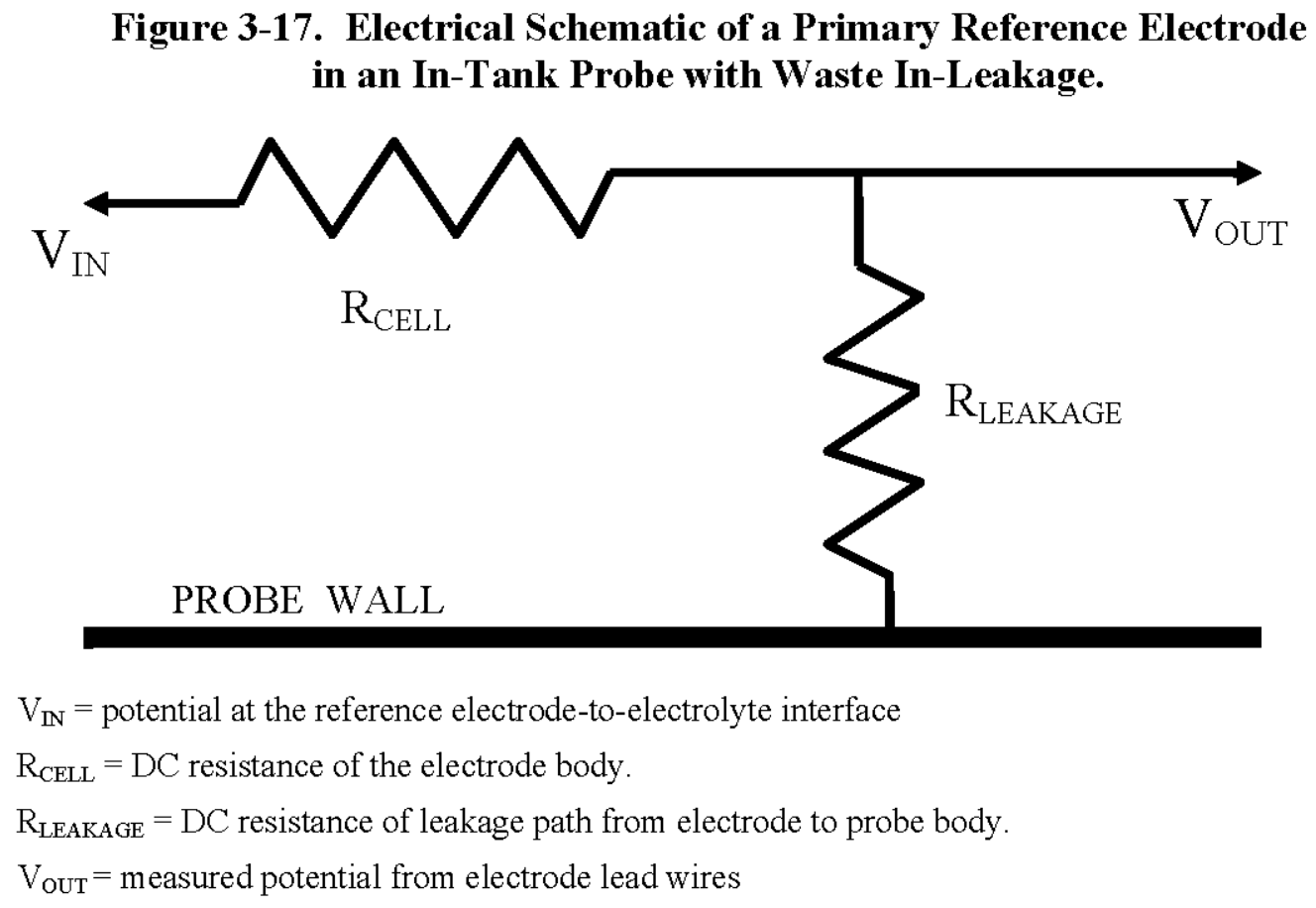


For primary reference electrodes, $\mathrm{R}_{\mathrm{CELL}}$ is very large and equal to the resistance through the porous Kynar junction and secondary junction. Under normal circumstances, the electrode is completely electrically isolated from the probe body, therefore $\mathrm{R}_{\mathrm{LEAKAGE}}$ can be considered to be infinite. Current can only flow from the electrode-to-electrolyte interface to the electrode lead. However, should waste in-leakage occur, $\mathrm{R}_{\mathrm{LEAKAGE}}$ will be equal to the resistance of the inleaked liquid between the electrode to the probe body.

The voltage potential at the electrode-tank waste interface $\left(\mathrm{V}_{\mathrm{IN}}\right)$ is typically measured by connecting a voltmeter to a lead terminated to an electrode. The voltage measured at the electrode lead ( $\mathrm{V}_{\text {OUT }}$ ) is equal to $\mathrm{V}_{\text {IN }}$ minus the voltage drop across $\mathrm{R}_{\text {CELL. When the electrode }}$ and probe body are electrically isolated, this measurement technique is an effective way to determine $\mathrm{V}_{\mathrm{IN}}$. The voltage drop across $\mathrm{R}_{\text {CELL }}$ should be negligible if a high impedance voltmeter is used, and $\mathrm{V}_{\text {OUT }}$ should approximate $\mathrm{V}_{\text {IN }}$.

If liquid in-leakage were to electrically connect a primary reference electrode to the probe body, as shown in Figure 3-17, current can flow from the electrode-to-electrolyte interface in two directions: to the electrode lead or to the probe body. $\mathrm{V}_{\text {OUT }}$ will no longer equal $\mathrm{V}_{\mathrm{IN}}$, and it will instead follow the voltage divider equation shown in Equation 1:

$$
V_{O U T}=\frac{R_{L E A K}}{R_{L E A K}+R_{C E L L}} \cdot V_{I N}
$$

Because $\mathrm{R}_{\text {CELL }}$ is large, $\mathrm{R}_{\mathrm{LEAK}}$ has a significant impact on the measurement of $\mathrm{V}_{\text {OUT }}$. When the voltage at the electrode lead ( $\left.\mathrm{V}_{\text {OUT }}\right)$ is measured against the voltage of the electrode housing, the resulting potential is equal to the voltage potential at the electrode-tank waste interface $\left(V_{I N}\right)$.

\subsection{RELATIONSHIP TO FARM DATA}

The 241-AY-101 test cell was designed to replicate the conditions in Tanks 241-AY-101 and 241-AY-102. In March, 2009 several secondary reference electrodes began to fail in the MPCMS probe installed in Tank 241-AY-102. Table 3-6 shows the approximate measured shift in potential recorded from each of the failed electrodes with respect to each of the three types of primary reference electrode.

The Tank column in Table 3-6 shows the approximate measured potential of the secondary reference electrodes made with respect to the primary reference electrodes installed on the 241-AY-102 MPCMS over the course of the initial failed electrode data shift. ${ }^{16}$ These values are very similar to the magnitude of the potentials collected for the copper, silver, and tank material electrodes wetted with waste simulant in the Waste column of Table 3-6.

\footnotetext{
${ }^{16}$ Data from Figures B4 and B5 of RPP-RPT-40661, 2009, 241-AY-102 Multi-Probe Corrosion Monitoring System: January 2010 Monthly Report.
} 
Table 3-6. Measured Potential Difference Recorded for 241-AY-102 Failed Secondary Reference Electrodes with Respect to Each MPCMS Primary Reference Electrode Compared to Data from Table 3-2.

\begin{tabular}{|c|c|c|c|c|}
\hline \multicolumn{5}{|c|}{$\mathrm{Ni}$} \\
\hline & Tank $[\mathrm{mV}]$ & Water [mV] & Waste [mV] & Foam [mV] \\
\hline AgCl & 200 & -232.9 & -594.5 & -176.9 \\
\hline Calomel & 100 & -234.1 & -596.2 & -163.8 \\
\hline $\mathrm{CuSO}_{4}$ & 100 & -234.5 & -596.5 & -169.8 \\
\hline \multicolumn{5}{|c|}{$\mathrm{Cu}$} \\
\hline & Tank [mV] & Water $[\mathrm{mV}]$ & Waste [mV] & Foam [mV] \\
\hline AgCl & 400 & -2.4 & -352.8 & 2.3 \\
\hline Calomel & 300 & 1 & -354.3 & 1.4 \\
\hline $\mathrm{CuSO}_{4}$ & 200 & -0.7 & -354.3 & 1.2 \\
\hline \multicolumn{5}{|c|}{ Ag } \\
\hline & Tank [mV] & Water [mV] & Waste [mV] & Foam [mV] \\
\hline AgCl & 500 & -215.8 & -648.3 & -42.2 \\
\hline Calomel & 400 & -106.5 & -649.9 & -128.2 \\
\hline $\mathrm{CuSO}_{4}$ & 400 & -217 & -649.5 & -42.6 \\
\hline \multicolumn{5}{|c|}{ AAR TC128 } \\
\hline & Tank [mV] & Water [mV] & Waste [mV] & Foam [mV] \\
\hline AgCl & 500 & -216.9 & -629.7 & -7.6 \\
\hline Calomel & 600 & -225.8 & -630.9 & -6.8 \\
\hline $\mathrm{CuSO}_{4}$ & 600 & -127.4 & -630.8 & -2.3 \\
\hline
\end{tabular}

While the shift in magnitude for most of the electrodes is similar, the shift in potential collected from the 241-AY-102 MPCMS moved in the more positive direction, whereas the experimental data moved in the more negative direction after the back of the electrodes were wetted. The reason for the disparity most likely stems from the mixed potential formed by multiple metals in electrical contact with the electrodes. The bodies of the electrodes used in the experiment were installed in stainless steel housings, while the electrodes installed on the corrosion probe are in contact with the much larger carbon steel body of the MPCMS.

The liquid in-leakage experiment demonstrated that wetting the back of an electrode with the most conductive fluid (waste simulant) generally had the greatest effect on the measured potential. This effect was particularly true of the tests run using 241-AY-101 waste simulant. The potential of the metallic electrodes wetted with 241-AY-101 waste simulant shifted by approximately $300 \mathrm{mV}$ to $650 \mathrm{mV}$ (with respect to $25^{\circ} \mathrm{C}$ MPCMS primary reference electrodes). Wetting the backs of most of the metallic electrodes with water or foam component liquid caused the electrodes to shift in potential by $0 \mathrm{mV}$ to $250 \mathrm{mV}$ (with respect to a clean electrode of the same type). The potential of the primary reference electrodes wetted with 241-AY-101 waste simulant shifted by approximately $150 \mathrm{mV}$ to $450 \mathrm{mV}$ (with respect to a clean electrode of the same type). Wetting the backs of the primary reference electrodes with water or foam 
component liquid caused the electrodes to shift in potential by approximately $0 \mathrm{mV}$ to $100 \mathrm{mV}$ (with respect to a clean electrode of the same type).

After installation, some of the metallic electrodes on the 241-AY-102 MPCMS shifted suddenly by $400-600 \mathrm{mV}$ as measured with respect to the primary reference electrodes. Even though the direction of the shift in the laboratory data is opposite the direction of the shift on failed electrodes in the field data, the similarity in the magnitudes of the shifts suggests the ingress of tank waste into the probe body.

\subsection{ELECTRODE ELECTROLYTE CONTAMINATION}

\subsection{BACKGROUND AND PURPOSE}

The primary reference electrodes on MPCMSs will eventually fail. Over time, all primary reference electrodes continuously immersed in a solution of interest will become contaminated by the solution of interest due to diffusion of solution into the electrode body through the porous electrode tip. In the instance of MPCMS electrodes, the diffusion process may be accelerated by radiation-induced swelling of the materials comprising the electrodes. Ideally, the potential of a primary reference electrode would remain fixed at a given temperature. However, contamination of the electrode filling solution will cause the potential of the reference electrode to drift under field conditions. Since the MPCMS represents a new application for these electrodes, it is unclear as to when such degradation can be expected or what the effect will be on electrode potential. Laboratory testing has been performed to characterize the effects of electrode contamination by tank waste. The test plan is described in detail in RPP-PLAN-43916. Test results are expected to aid in the evaluation of field data from the Tank 241-AY-102 MPCMS, and MPCMSs installed in other tanks.

\subsection{EXPERIMENTAL SETUP}

The electrode electrolyte contamination experimental apparatus consists of two test cells, each containing the following:

1. One each of the MPCMS-style primary reference electrodes (i.e., $\mathrm{Ag} / \mathrm{AgCl}$, $\mathrm{Cu} / \mathrm{CuSO}_{4}$, and calomel),

2. One tank material electrode, and

3. Approximately one liter of tank waste stimulant from either 241-AY-101 or 241-AN-107 tanks.

A single insulated constant temperature bath was used for this set of experiments. Both the Teflon test cells containing the electrodes under test and the beaker containing a set of MPCMSstyle primary reference electrodes and a set of laboratory-grade primary reference electrodes were partially immersed in this constant $25^{\circ} \mathrm{C}$ insulated bath. Temperature control of the bath was attained using a PolyScience Model 7306 temperature controller and water-cooled copper 
cooling coils. Condensers were not used due to the short duration of the testing. A set of potassium chloride salt bridges were installed between each test cell containing the electrodes under test and the $25^{\circ} \mathrm{C}$ reference electrode cell. Figure $4-1$ depicts the experimental setup for the electrolyte contamination test.

Figure 41. Electrode Electrolyte Contamination Test Setup.

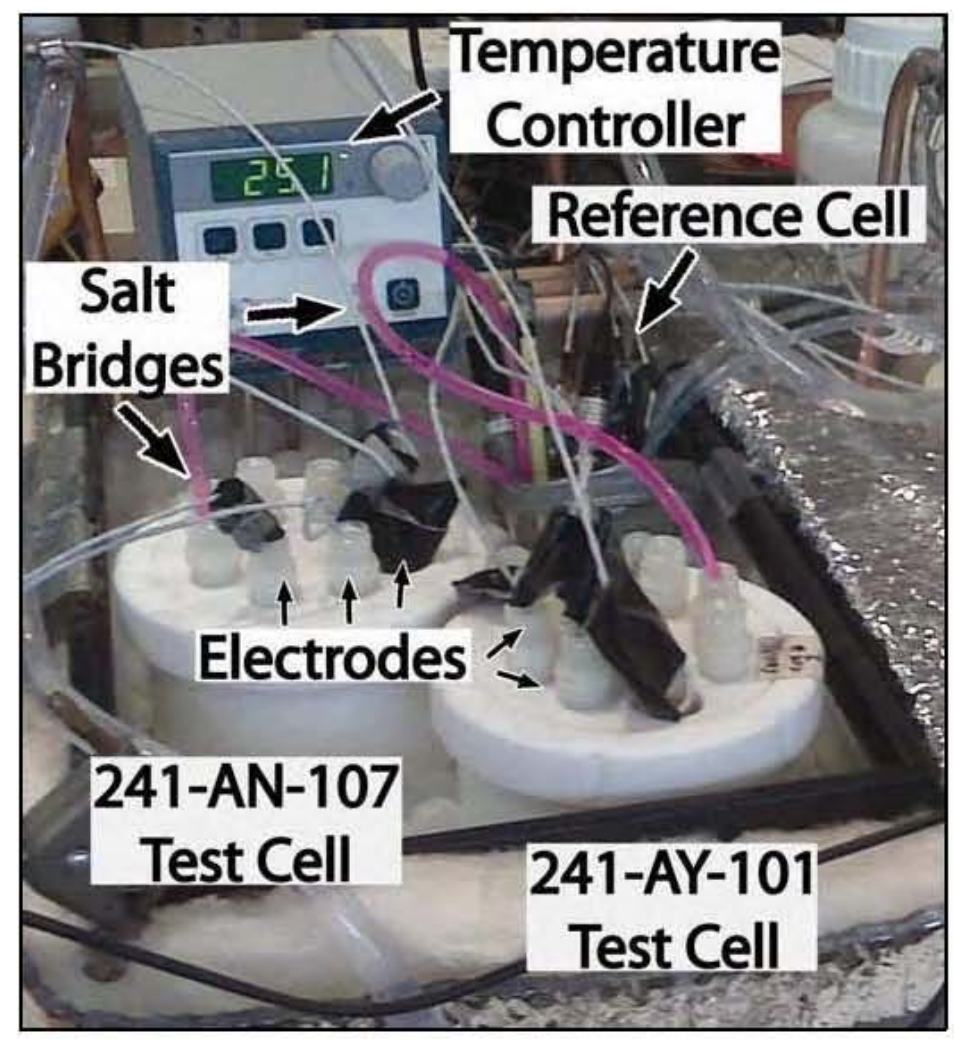

The general test procedure is described below:

1. Fill a Test Cell \#1 with at least 1L of 241-AY-101 simulant.

2. Immerse an AAR TC128 electrode into Test Cell \#1.

3. Immerse one of each of the three types of MPCMS primary reference electrodes in Test Cell \#1 (calomel, $\mathrm{Cu} / \mathrm{CuSO} 4, \mathrm{Ag} / \mathrm{AgCl}$ )

4. Fill Test Cell \#2 with at least $1 \mathrm{~L}$ of $241-\mathrm{AN}-107$ simulant.

5. Immerse an ASTM A537 CL1 electrode into Test Cell \#2.

6. Immerse one of each of the three types of MPCMS primary reference electrodes in Test Cell \#2 (calomel, $\mathrm{Cu} / \mathrm{CuSO} 4, \mathrm{Ag} / \mathrm{AgCl}$ ).

7. Immerse Test Cell \#1 and Test Cell \#2 in a constant temperature bath and allow test cell temperatures time to equilibrate at approximately $35^{\circ} \mathrm{C}$. 
8. Set aside one of each of the three types of MPCMS primary reference electrodes (calomel, $\mathrm{Cu} / \mathrm{CuSO} 4, \mathrm{Ag} / \mathrm{AgCl}$ ) and allow to equilibrate at room temperature.

9. Set aside one of each of the three types of laboratory-grade primary reference electrodes (calomel, $\mathrm{Cu} / \mathrm{CuSO} 4, \mathrm{Ag} / \mathrm{AgCl}$ ) and allow to equilibrate at room temperature.

10. After test cell temperature and electrode potentials have stabilized, make the following measurements in each test cell and record these measurements on the data sheets provided in Appendix C:

- Test solution $\mathrm{pH}$, bath temperature, and mark time and date,

- Measure the potentials of the ASTM A537 CL1 and AAR TC128 electrodes under test with respect to:

- Each of the three MPCMS-style primary reference electrodes under test in the respective test cells (calomel, $\mathrm{Cu} / \mathrm{CuSO}_{4}, \mathrm{Ag} / \mathrm{AgCl}$ ),

- Each of the three room temperature MPCMS-style primary reference electrodes (calomel, $\mathrm{Cu} / \mathrm{CuSO}_{4}, \mathrm{Ag} / \mathrm{AgCl}$ ), and

- Each of the three room temperature laboratory-grade primary reference electrodes (calomel, $\mathrm{Cu} / \mathrm{CuSO}_{4}, \mathrm{Ag} / \mathrm{AgCl}$ ).

- Measure the potentials of each of the MPCMS-style primary reference electrodes under test (calomel, $\mathrm{Cu} / \mathrm{CuSO}_{4}, \mathrm{Ag} / \mathrm{AgCl}$ ) with respect to a $25^{\circ} \mathrm{C}$ MPCMS-style reference electrode of the same type and a $25^{\circ} \mathrm{C}$ laboratory-grade reference electrode of the same type (e.g., measure the potential of the immersed MPCMSstyle calomel primary reference electrode with respect to a $25^{\circ} \mathrm{C}$ MPCMS-style and a $25^{\circ} \mathrm{C}$ laboratory-grade calomel primary reference electrode, etc.).

11. Using a hypodermic needle or other appropriate device, contaminate the filling solution of each of the MPCMS-style primary reference electrodes under test (calomel, $\mathrm{Cu} / \mathrm{CuSO} 4, \mathrm{Ag} / \mathrm{AgCl}$ ) in each Test Cell with approximately 0.1 to $0.5 \mathrm{~mL}$ of the appropriate waste simulant. Agitate the contaminated electrodes to ensure adequate mixing of the contaminant and filling solution.

12. Repeat the potential measurements described in Step 10.

13. Repeat Steps 11 and 12 at appropriate intervals until no significant changes in potential are recorded during each measurement cycle, the primary reference electrode body has no additional capacity for contaminant, or until otherwise terminated by the Test Director.

The test matrix is shown in Table 4-1. Test exceptions for the procedure detailed in RPP-PLAN43916 are listed in Appendix D. 
RPP-RPT-44463, Rev. 0

Table 4-1. Electrode Electrolyte Contamination Test Matrix.

\begin{tabular}{|c|c|c|}
\hline Test Electrode & \multicolumn{2}{|c|}{ Electrodes Used as Test Reference } \\
\hline \multirow{3}{*}{ MPCMS-style $\mathrm{Ag} / \mathrm{AgCl}$} & \multicolumn{2}{|c|}{ MPCMS-style $\mathrm{Ag} / \mathrm{AgCl}$} \\
\hline & \multicolumn{2}{|c|}{ Laboratory-grade $\mathrm{Ag} / \mathrm{AgCl}$} \\
\hline & \multicolumn{2}{|c|}{ AAR TC- 128 or ASTM A537 CL1 } \\
\hline \multirow{3}{*}{ MPCMS-style Calomel } & \multicolumn{2}{|c|}{ MPCMS-style Calomel } \\
\hline & \multicolumn{2}{|c|}{ Laboratory-grade Calomel } \\
\hline & \multicolumn{2}{|c|}{ AAR TC-128 or ASTM A537 CL1 } \\
\hline \multirow{3}{*}{ MPCMS-style $\mathrm{Cu} / \mathrm{CuSO}_{4}$} & \multicolumn{2}{|c|}{ MPCMS-style $\mathrm{Cu} / \mathrm{CuSO}_{4}$} \\
\hline & \multicolumn{2}{|c|}{ Laboratory-grade $\mathrm{Cu} / \mathrm{CuSO}_{4}$} \\
\hline & \multicolumn{2}{|c|}{ AAR TC-128 or ASTM A537 CL1 } \\
\hline \multirow{9}{*}{ TC-128 or ASTM A537 CL1 } & \multirow{3}{*}{ MPCMS-style under test } & $\mathrm{Ag} / \mathrm{AgCl}$ \\
\hline & & Calomel \\
\hline & & $\mathrm{Cu} / \mathrm{CuSO}_{4}$ \\
\hline & \multirow{3}{*}{ MPCMS-style reference } & $\mathrm{Ag} / \mathrm{AgCl}$ \\
\hline & & Calomel \\
\hline & & $\mathrm{Cu} / \mathrm{CuSO}_{4}$ \\
\hline & \multirow{3}{*}{ Laboratory-grade reference } & $\mathrm{Ag} / \mathrm{AgCl}$ \\
\hline & & Calomel \\
\hline & & $\mathrm{Cu} / \mathrm{CuSO}_{4}$ \\
\hline
\end{tabular}

\subsection{RESULTS}

Figures 4-2 and 4-3 show the effects of contamination of the primary reference electrode electrolyte solution on the measured potential. Similar patterns were observed during the progressive contamination of each primary reference electrode for both waste simulants. However, a larger effect was observed on the electrodes contaminated with 241-AY-101 simulant. The potentials of the calomel and $\mathrm{Ag} / \mathrm{AgCl}$ electrodes, when measured with respect to corresponding reference electrodes, remain close to zero for the duration of the experiment. Nevertheless, the measured potential for the $\mathrm{Cu} / \mathrm{CuSO}_{4}$ primary reference electrode fluctuates over $100 \mathrm{mV}$ with an overall trend moving in the negative direction.

Similarly, the potentials of the tank material electrodes in each of the test cells experience fluctuations in measured potential during progressive electrolyte contamination of the primary reference electrodes under test. The overall potential shift for the AAR TC-128 tank material electrode measured with respect to the primary reference electrodes contaminated with the 241-AY-101 waste simulant is $100 \mathrm{mV}$ in the positive direction. The resulting potential shift for the ASTM A537 CL1 tank steel material electrode when measured with respect to the primary reference electrodes contaminated with the $241-\mathrm{AN}-107$ simulant is approximately $10 \mathrm{mV}$ in the negative direction.

Due to the large amount of data collected in the test program, it is not possible or necessary to show all data to summarize the general results of testing. Instead, selected data representative of the results of testing are presented below in an effort to summarize the general results of testing. Additional test data are shown in Appendix E should the reader wish to investigate the results of testing in greater detail. 
Figure 4-2. Measured Potentials of the MPCMS Primary Reference Electrodes Under Test with Respect to the Corresponding $25^{\circ} \mathrm{C}$ Electrodes and Measured Potentials of the Tank

Material Electrodes Measured with Respect to the MCPMS Electrodes Under Test in 241-AY-101 Waste Simulant.

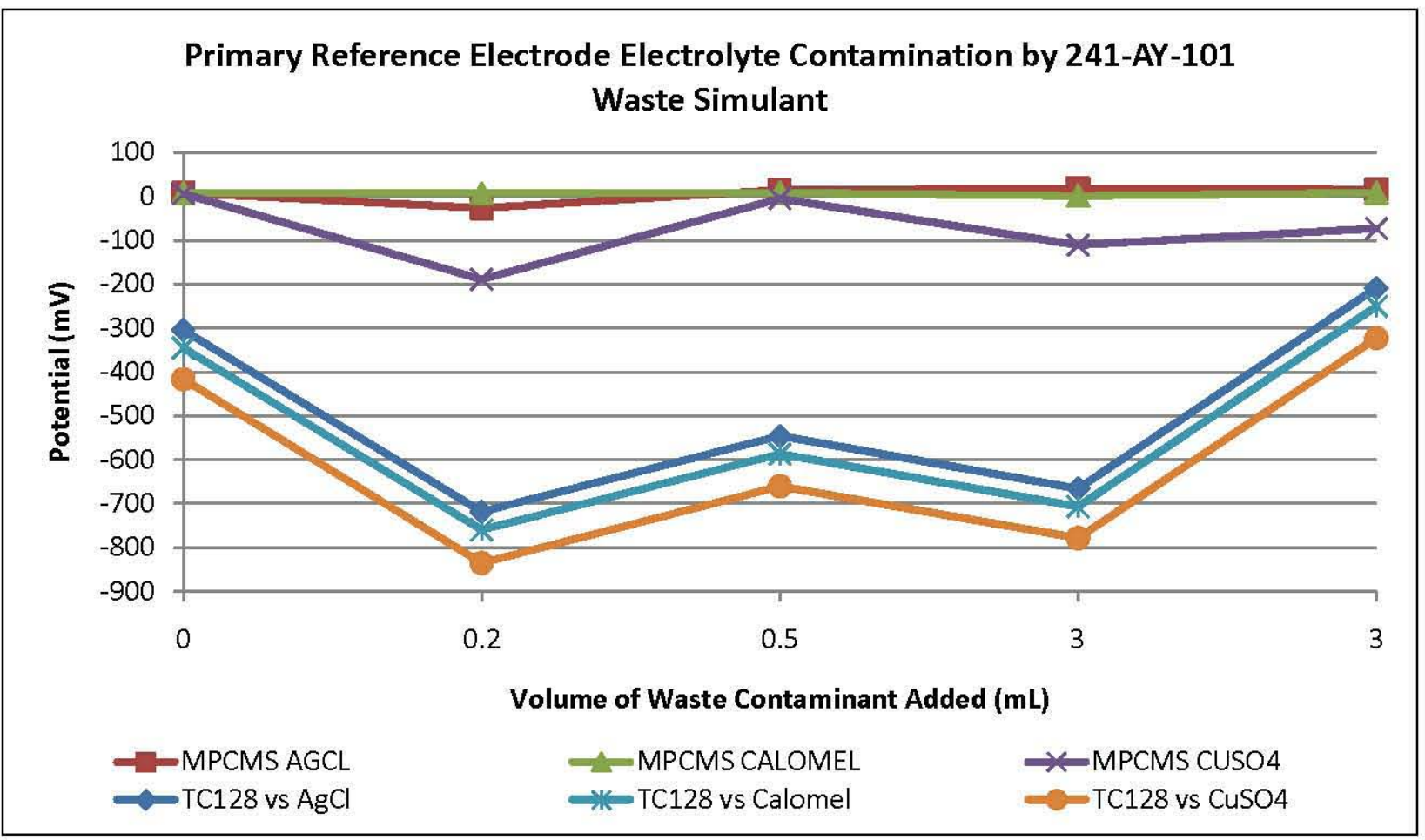


Figure 4-3. Measured Potentials of the MPCMS Primary Reference Electrodes Under Test with Respect to the Corresponding $25^{\circ} \mathrm{C}$ Electrodes and Measured Potentials of the Tank Material Electrodes Measured with Respect to the MCPMS Electrodes Under Test in 241-AN-107 Waste Simulant.

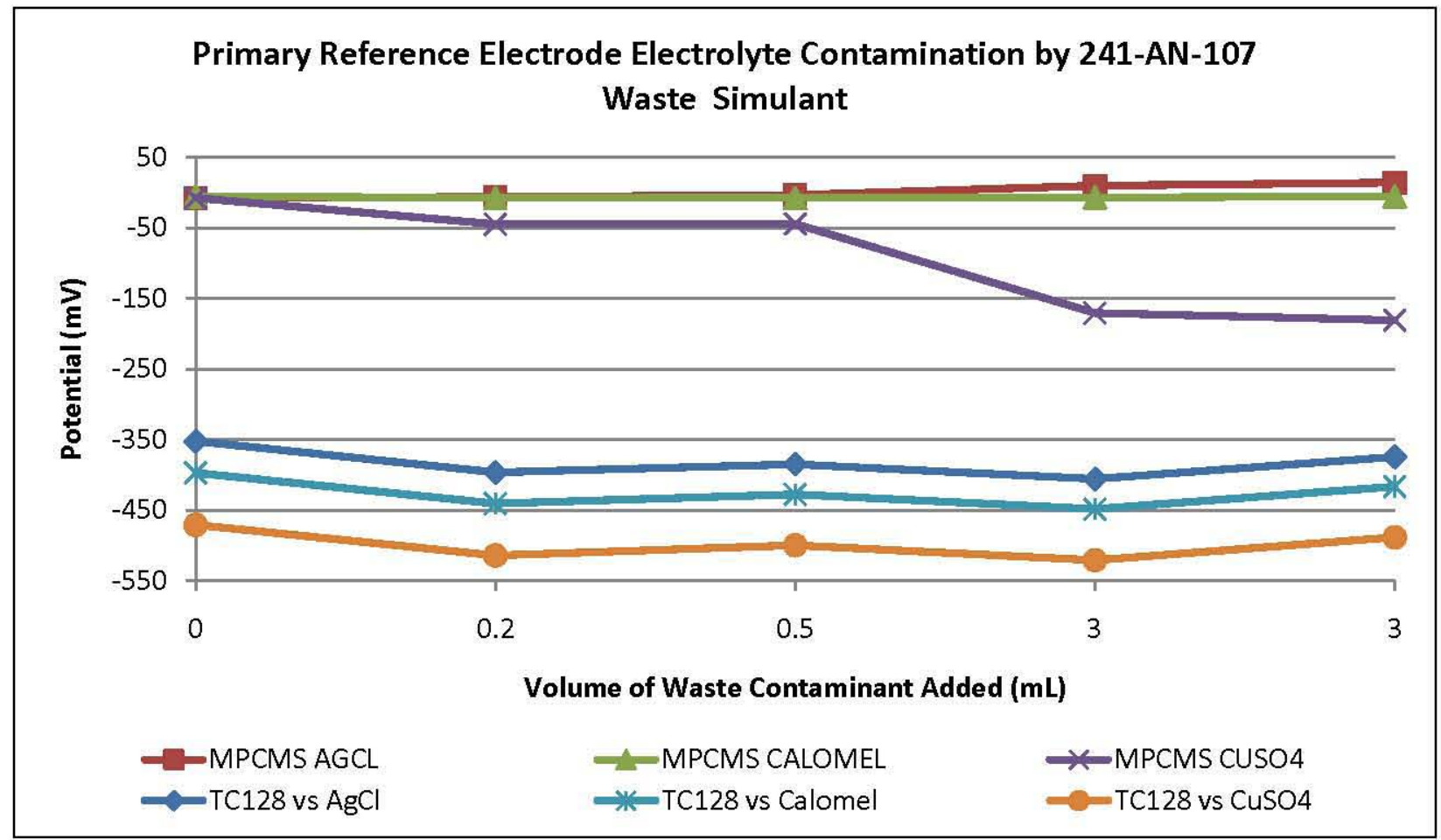

Because of the porous frit, gradual failure due to loss/contamination of electrolyte fill solution has been predicted for the MPCMS-style primary reference electrodes installed on the corrosion probes. As a result, the electrolyte contamination experiment was designed to simulate the progressive contamination at an accelerated rate.

Similar effects on electrode potential were observed during the progressive contamination of each primary reference electrode for both waste simulants. However, the 241-AY-101 simulant produced a greater shift in electrode potential. The potentials of the calomel and $\mathrm{Ag} / \mathrm{AgCl}$ electrodes, as measured with respect to similar uncontaminated reference electrodes, did not change substantially over the course of the experiment. The potential of the $\mathrm{Cu} / \mathrm{CuSO} \mathrm{electrode}_{4}$ shifted by approximately $-100 \mathrm{mV}$ over the course the experiment.

The measured potentials of the tank material electrodes in each of the test cells fluctuated during the progressive stages of reference electrode electrolyte contamination. The potential of the AAR TC-128 tank material electrode, as measured with respect to the contaminated primary reference electrodes, shifted in the positive direction by approximately $100 \mathrm{mV}$. The potential of the ASTM A537 CL1 tank material electrode, as measured with respect to the contaminated primary reference electrodes, shifted in the negative direction by approximately $10 \mathrm{mV}$.

The functionality of the MPCMS-style primary reference electrodes is dependent on two aspects of the composition of the fill solution: 
1. That the solution has a sufficient number of ions available to efficiently transfer charge across the frit, and

2. That the concentration of the ions affecting the potential on the electrode is unchanged except as a response to the measurement of interest.

The first aspect indicates that the fill solution should be an equitransferent solution where the anions and cations have equivalent mobilities to carry current through the frit. The standard voltage produced by the electrode can only be correct if no additional voltage is supplied by a liquid junction potential formed at the frit. Formation of a liquid junction can occur if two separate electrolytes come into contact with each other, and smaller, more mobile ions move across the boundary, disrupting the voltage. To combat liquid junction formation, a highly concentrated filling solution is used to ensure that the supplied ions carry the current, thus producing the correct voltage.

Typical standard laboratory reference electrodes rely on gravity driven flow of the fill solution through the frit. Flow is ensured by allowing the inner chamber of the electrode contact with the atmosphere through a small hole in the top of the electrode. This hole prevents a pressure decrease in the inner chamber, which can halt electrolyte flow. In the lab, the electrode filling solution is simply replaced as it is depleted. In the case of MPCMS-style primary reference electrodes, the inner chamber is isolated from the atmosphere and electrolyte flow is compromised. The magnitude of the resulting liquid junction potential (and therefore the deflection of the electrode potential from expected values) has not been determined.

Under experimental conditions, a change in potential of less than $25 \mathrm{mV}$ is observed for the calomel and $\mathrm{Ag} / \mathrm{AgCl}$ electrodes when measured with respect to the same MPCMS electrodes at $25^{\circ} \mathrm{C}$. Numerous chemical reactions may be taking place during the electrolyte contamination process due to the complex chemical composition of the simulants; however, the central chemistry driving the reference electrode potential appears to be relatively unaffected.

Taking the $\mathrm{Ag} / \mathrm{AgCl}$ reference electrode as an example, the Nernst Equation for the potential of the reference electrode is shown in Equation 2:

$$
E=E^{0}-\frac{R T}{z F} \ln a_{C l}
$$

Where:

$\mathrm{E}$ is the total voltage,

$\mathrm{E}^{0}$ is the standard cell potential (in this case $0.222 \mathrm{~V}$ ),

$\mathrm{R}$ is the gas constant,

$\mathrm{z}$ is the amount of electrons transferred (in this case 1),

$\mathrm{F}$ is Faraday's constant, and

$a_{\mathrm{Cl}}$ is the activity of the chloride ion in the inner chamber of the electrode. 
In equation $2, \frac{R T}{Z F}$ and $\mathrm{E}^{0}$ are constants. It can be seen that the total voltage of the cell is dependent on the activity of chloride in solution. Activity, also called effective concentration, depends on the self-interactive behavior of an ion in solution. Activity can be approximated by molar concentration in both ideal and dilute solutions. In concentrated solutions, however, activity is dependent on but not equal to molar concentration. As a result, the total voltage of the cell is therefore also dependent on the concentration of chloride in solution.

When the electrolyte is contaminated with tank waste simulant, it is probable that two processes affect the potential. The most important process is likely the dilution of the chloride ions in the fill solution, causing an overall decrease in concentration. The magnitude of this effect can be calculated using the Nernst equation. In the case where the fill solution is saturated with potassium chloride, the activity of chloride $\left(a_{\mathrm{Cl}}\right)$ is equal to 3 , and the second term in the Nernst equation has a value of $0.023 \mathrm{~V}$, yielding the expected potential for a $\mathrm{Ag} / \mathrm{AgCl}$ electrode of $0.199 \mathrm{~V}$ at $25^{\circ} \mathrm{C}$. Decreasing $a_{\mathrm{Cl}}$ in the Nernst equation to a value of 1 causes the second term to decrease to $0 \mathrm{~V}$, yielding a potential of $0.222 \mathrm{~V}$ (the standard cell potential). Decreasing $a_{\mathrm{Cl}}$ in the calculation to equal that of the 241-AY-101 simulant (0.05) decreases the second term in the Nernst equation to $-0.077 \mathrm{~V}$, yielding a potential of $0.299 \mathrm{~V}$. Completely replacing the fill solution with stimulant should produce a change in potential on the order of $100 \mathrm{mV}$.

The fact that the change in potential was smaller than $100 \mathrm{mV}$ when the fill solution was removed and replaced with waste simulant suggests that other chemical processes are causing electron flow at the silver wire. The simulants contain anions and other molecules that may complex silver. If the formation of silver complexes takes place, metallic silver atoms on the electrode wire would be removed from the wire and introduced into solution as complexes, possibly liberating electrons at the wire surface. The activity of anions forming silver complexes would then be relevant to the calculation of the cell potential using the Nernst equation in a manner analogous to that for chloride. The result would be an increase in current, and therefore voltage. Whether or not significant complexation is taking place and its effect on the reference electrode potential is not determined here, but it may be conceptually relevant.

Similar reasoning applies to the observed change in potential for the calomel reference electrode except that the relevant Nernst equation has a constant involving the $\mathrm{K}_{\mathrm{sp}}$ of calomel and involves the square of the chloride activity ( $\mathrm{z}$ is 2 ). Dilution of the fill solution decreases the chloride concentration and mercury may also form complexes with the components of the stimulants.

Explaining the trends observed for the $\mathrm{Cu} / \mathrm{CuSO}_{4}$ electrode is made more complicated by the fact that a gas was liberated after the addition of the simulant. Based on the chemistry of the simulants, two possible reactions may be occurring to cause the gas evolution. Because the 241-AY-101 simulant has a high carbonate concentration, a $\mathrm{pH}$ driven release of $\mathrm{CO}_{2}$ may cause the bubbling, and slightly erratic potential measurements. The other process that may cause the gas evolution may stem from multiple redox reactions occurring as the simulant is added. Possible gasses that could be emitted include oxygen and hydrogen. Besides the slightly irregular potential data measured for the $\mathrm{Cu} / \mathrm{CuSO}_{4}$ electrode, it is noted that the overall direction of the potential is in the negative direction. In order to explain this trend, the Nernst equation for the electrode is investigated (Equation 3). Because the second half of the equation is added to the cell potential variable, $E^{0}$, the resultant total voltage, $E$, would increase as the activity is 
decreased. The potential difference between the electrode and a reference electrode would then move in a more negative direction.

$$
E=E^{0}+\frac{R T}{Z F} \ln a_{C u^{2+}}
$$

An equally important relationship to understand is the effect of the potential of the tank material electrodes made with respect to the primary reference electrodes as progressive contamination ensues. Focus for this discussion should stay on the first three steps of the contamination process, as the electrodes still contain the original electrolyte in addition to the waste simulant. Because only a small shift in potential is observed in the primary reference electrodes under test, it is difficult to argue that the change in potential observed for the tank material electrodes is related to the contamination process. The potential shift for the tank material electrodes can most likely be attributed to change over time or other factors not considered for this experiment.

\subsection{SUMMARY AND CONCLUSIONS}

\subsection{TEMPERATURE}

Temperature testing was performed both to determine the effect of temperature on MPCMS primary reference electrode potentials and to establish a baseline against which to measure the potential of tank material electrodes during temperature variations. Testing indicated that a relatively direct relationship exists between the MPCMS primary reference electrode potentials and temperature. As with data from the MPCMS installed in 241-AN-102, test data indicated that the MPCMS-style primary reference electrodes shift with temperature by a greater magnitude than predicted by the electrode temperature coefficients. No significant trend was observed between tank material electrode potential and temperature. Relatively large variations in the potential of the steel electrodes were observed in the laboratory testing, similar to the behavior observed in the field data shortly after installation of the MPCMS. These fluctuations are most likely associated with the electrode passivation process over a variety of temperatures.

The similarity between tank data and experimental data indicates that the tank waste environment is not likely the cause of the larger than expected potential shift with temperature. Reasons for the larger than expected shift may be related to electrode frit design or the gel-type electrode filling solution used in the MPCMS-style electrodes. Most data from the 241-AN-102 MPCMS shows a direct relationship between primary reference electrode potential and temperature with one notable exception. Data from the 241-AN-102 MPCMS shows an inverse relationship with tank temperature variations in the supernatant region. Reasons for this effect are currently unknown, but may have to do with the relative installation locations of the thermocouple tree and the MPCMS in the tank.

\subsection{LIQUID IN-LEAKAGE}

Liquid in-leakage testing was performed to better understand the effects of forming an electrical short between each type of electrode and a simulated MPCMS probe body, and to help identify 
the conductive liquid contained in Tank 241-AY-102. Shifts in potential induced by the electrode wetting experiments generally correlated with the conductivity of the wetting liquid. 241-AY-101 waste simulant seems to be more conductive than 241-AN-107 waste simulant.

Both waste simulants were more conductive than water and Foam Part B Component. Water and Foam Part B Component seem to have similar conductivities. The observed potential differences induced by 241-AY-101 tank waste are opposite in sign, but similar in magnitude to the potential shifts recorded on failed electrodes on the MPCMS in Tank 241-AY-102. Though the direction of the potential shift in the laboratory data is opposite of that observed in tank data, the magnitude of the shift may indicate that tank waste has intruded into the 241-AY-102 MPCMS.

\subsection{ELECTROLYTE CONTAMINATION}

An electrolyte contamination experiment was performed to characterize the effects of a progressive contamination of MPCMS primary reference electrodes. Test results indicate that the MPCMS-style electrodes are relatively insensitive to tank waste simulant contamination. This lack of response is not an expected result. A clear shift in potential was expected with progressive contamination of each MPCMS primary reference electrode. It is possible that these results indicate that the primary reference electrodes can function appropriately even after contamination with tank waste. Because the results obtained from the electrolyte contamination testing are so unexpected and difficult to explain, further testing should likely be performed to both confirm and derive a basis for the results of this experiment.

\subsection{REFERENCES}

Baboian R., 2002, "NACE Corrosion Engineers Reference Book," Third Edition, NACE International, Houston, Texas, p. 91.

RPP-PLAN-43915, 2010, Test Plan for Evaluating the Influence of Temperature on MPCMS Electrode Corrosion Potentials, Revision 0, Washington River Protection Solutions, LLC, Richland, Washington.

RPP-PLAN-43916, 2010, Test Plan for Evaluating the Effects of MPCMS Primary Reference Electrode Electrolyte Contamination and MPCMS Probe Body Liquid In-Leakage, Revision 0, Washington River Protection Solutions, LLC, Richland, Washington.

RPP-RPT-38932, 2009, 241-AN-102 Multi-Probe Corrosion Monitoring System: September, October, and November Quarterly Report, Revision 10, Washington River Protection Solutions, LLC, Richland, Washington.

RPP-RPT-40633, 2009, Factory Acceptance Test Report for the 241-AY-102 Multi-Probe Corrosion Monitoring System, Revision 0, Washington River Protection Solutions, LLC, Richland, Washington.

RPP-RPT-40661, 2009, 241-AY-102 Multi-Probe Corrosion Monitoring System: Weeks 13 and 14 Report, Revision 12, Washington River Protection Solutions, LLC, Richland, Washington. 
RPP-RPT-40661, 2009, 241-AY-102 Multi-Probe Corrosion Monitoring System: January 2010 Monthly Report, Revision 20A, Washington River Protection Solutions, LLC, Richland, Washington.

RPP-RPT-40867, 2009, Construction Acceptance and Process Test Report for the 241-AY-102 Multi-Probe Corrosion Monitoring System, Revision 0, Washington River Protection Solutions, LLC, Richland, Washington.

RPP-SPEC-32496, 2007, Procurement Specification for AN-102 Corrosion Probe Assembly, Revision 0, CH2M HILL Hanford Group, Inc., Richland, Washington.

RPP-SPEC-35429, 2007, Procurement Specification for AY-102 Corrosion Probe Assembly, Revision 1, CH2M HILL Hanford Group, Inc., Richland, Washington.

Skoog, D.A., West, D.M., and Holler, F.J., 1996, "Fundamentals of Analytical Chemistry (7th Edition),"), p. 388., Harcourt Brace College Publishers, Fort Worth, Texas. 
RPP-RPT-44463, Rev. 0

APPENDIX A

WASTE SIMULANT COMPOSITIONS 
RPP-RPT-44463, Rev. 0

\begin{tabular}{|c|c|c|c|}
\hline \multicolumn{4}{|c|}{ 241-AY-101 Supernatant Waste Simulant Recipe (4-Liter Batch, $\mathrm{pH}=13$ ) } \\
\hline \multicolumn{4}{|c|}{ Tare a carboy and then add the following, in order: } \\
\hline Compound & Formula & $\begin{array}{l}\text { Mass }(g) \text { for } 1 \mathrm{~L} \\
\text { of solution }\end{array}$ & $\begin{array}{l}\text { Mass }(g) \text { for } 4 \mathrm{~L} \\
\quad \text { of solution }\end{array}$ \\
\hline Sodium Aluminate & $\mathrm{NaAlO}_{2} \cdot 2 \mathrm{H}_{2} \mathrm{O}$ & 12.63 & 50.51 \\
\hline Sodium Chloride & $\mathrm{NaCl}$ & 1.06 & 4.25 \\
\hline Sodium Fluoride & $\mathrm{NaF}$ & 0.58 & 2.32 \\
\hline Sodium Chromate & $\mathrm{Na}_{2} \mathrm{Cr}_{2} \mathrm{O}_{4}$ & 0.67 & 2.67 \\
\hline Sodium Sulfate & $\mathrm{Na}_{2} \mathrm{SO}_{4}$ & 2.83 & 11.31 \\
\hline Sodium Phosphate, 12-Hydrate & $\mathrm{Na}_{3} \mathrm{PO}_{4} 12 \mathrm{H}_{2} \mathrm{O}$ & 18.85 & 75.41 \\
\hline Sodium Formate & $\mathrm{NaHCOO}$ & 0.86 & 3.45 \\
\hline Sodium Acetate Trihydrate & $\mathrm{NaCH}_{3} \mathrm{COO} .3 \mathrm{H}_{2} \mathrm{O}$ & 1.21 & 4.83 \\
\hline Sodium Oxalate & $\mathrm{Na}_{2} \mathrm{C}_{2} \mathrm{O}_{4}$ & 0.67 & 2.68 \\
\hline Sodium Carbonate & $\mathrm{Na}_{2} \mathrm{CO}_{3}$ & 21.30 & 85.21 \\
\hline Sodium Nitrate & $\mathrm{NaNO}_{3}$ & 113.04 & 452.15 \\
\hline Sodium Nitrite & $\mathrm{NaNO}_{2}$ & 14.15 & 56.59 \\
\hline Sodium Silicate & $\mathrm{Na}_{2} \mathrm{SiO}_{3} \cdot 9 \mathrm{H}_{2} \mathrm{O}$ & 0.49 & 1.97 \\
\hline Glycolic Acid & $\mathrm{C}_{2} \mathrm{H}_{4} \mathrm{O}_{3}$ & 0.80 & 3.20 \\
\hline Sodium Hydroxide & $\mathrm{NaOH}$ & 28.44 & 113.76 \\
\hline \multicolumn{4}{|c|}{ Adjust total solution volume to $2550 \mathrm{~mL}$ by adding $\mathrm{Dl}$ water. } \\
\hline \multicolumn{4}{|c|}{ Adjust solution temperature to $50^{\circ} \mathrm{C}$ to $60^{\circ} \mathrm{C}$} \\
\hline \multicolumn{4}{|c|}{$\begin{array}{l}\text { Filter solution by vacuum through medium glass filter. Handle with caution, hot and caustic } \\
\text { solution. }\end{array}$} \\
\hline \multicolumn{4}{|c|}{ Rinse beaker with approximately $50 \mathrm{~mL}$ of DI water. } \\
\hline \multicolumn{4}{|c|}{ Rinse filter with approximately $50 \mathrm{~mL}$ of $\mathrm{DI}$ water. } \\
\hline \multicolumn{4}{|c|}{ Transfer final filtrate and rinse solutions to large beaker with stir bar. } \\
\hline \multicolumn{4}{|c|}{ Measure and record initial pH: 13.12 . } \\
\hline \multicolumn{4}{|l|}{ Check to ensure $\mathrm{pH}$ is $>13$. } \\
\hline \multicolumn{4}{|c|}{ Transfer to volumetric flask and include rinse with DI water. Allow solution to cool. } \\
\hline \multicolumn{4}{|c|}{ Adjust final solution to volume of $4 \mathrm{~L}$ with $\mathrm{DI}$ water, and mix thoroughly. } \\
\hline Measure and final pH: 13.50. & & & \\
\hline
\end{tabular}


RPP-RPT-44463, Rev. 0

\begin{tabular}{|c|c|c|c|}
\hline \multicolumn{4}{|c|}{ 241-AN-107 Supernatant Waste Simulant Recipe (4-Liter Batch, pH = 10) } \\
\hline \multicolumn{4}{|c|}{ Tare a carboy and then add the following, in order: } \\
\hline Compound & Formula & $\begin{array}{l}\text { Mass }(\mathrm{g}) \\
\text { for } 1 \mathrm{~L} \text { of } \\
\text { solution }\end{array}$ & $\begin{array}{l}\text { Mass }(\mathrm{g}) \\
\text { for } 4 \mathrm{~L} \text { of } \\
\text { solution }\end{array}$ \\
\hline Deionized Water & $\mathrm{H}_{2} \mathrm{O}$ & 200.00 & 800.00 \\
\hline Calcium Nitrate, 4-Hydrate & $\mathrm{Ca}\left(\mathrm{NO}_{3}\right)_{2} \cdot 4 \mathrm{H}_{2} \mathrm{O}$ & 3.48 & 13.92 \\
\hline Cerium Nitrate, 6-Hydrate & $\mathrm{Ce}\left(\mathrm{NO}_{3}\right)_{3} \cdot 6 \mathrm{H}_{2} \mathrm{O}$ & 0.16 & 0.64 \\
\hline Cesium Nitrate & $\mathrm{CsNO}_{3}$ & 0.03 & 0.11 \\
\hline Copper Nitrate, 2.5 -Hydrate & $\mathrm{Cu}\left(\mathrm{NO}_{3}\right)_{2} \cdot 2.5 \mathrm{H}_{2} \mathrm{O}$ & 0.11 & 0.44 \\
\hline Ferric Nitrate, 9-Hydrate & $\mathrm{Fe}\left(\mathrm{NO}_{3}\right)_{3} \cdot 9 \mathrm{H}_{2} \mathrm{O}$ & 12.23 & 48.92 \\
\hline Lanthanum Nitrate & $\mathrm{La}\left(\mathrm{NO}_{3}\right)_{3} \cdot 6 \mathrm{H}_{2} \mathrm{O}$ & 0.14 & 0.56 \\
\hline Lead Nitrate & $\mathrm{Pb}\left(\mathrm{NO}_{3}\right)_{2}$ & 0.62 & 2.48 \\
\hline Magnesium Nitrate, 6-Hydrate & $\mathrm{Mg}\left(\mathrm{NO}_{3}\right)_{2} 6 \mathrm{H}_{2} \mathrm{O}$ & 0.26 & 1.04 \\
\hline Manganous Chloride, 4-Hydrate & $\mathrm{MnCl}_{2} \cdot 4 \mathrm{H}_{2} \mathrm{O}$ & 2.03 & 8.12 \\
\hline Neodymium Nitrate, 6-Hydrate & $\mathrm{Nd}\left(\mathrm{NO}_{3}\right)_{3} \cdot 6 \mathrm{H}_{2} \mathrm{O}$ & 0.29 & 1.16 \\
\hline Nickel Nitrate, 6-Hydrate & $\mathrm{Ni}(\mathrm{NO} 3) 2.6 \mathrm{H}_{2} \mathrm{O}$ & 2.63 & 10.52 \\
\hline Potassium Nitrate & $\mathrm{KNO}_{3}$ & 4.60 & 18.40 \\
\hline Strontium Nitrate & $\mathrm{Sr}\left(\mathrm{NO}_{3}\right)_{2}$ & 0.02 & 0.06 \\
\hline Zinc Nitrate, 6-Hydrate & $\mathrm{Zn}\left(\mathrm{NO}_{3}\right)_{2} \cdot 6 \mathrm{H}_{2} \mathrm{O}$ & 0.21 & 0.84 \\
\hline Zirconyl Nitrate & $\mathrm{ZrO}\left(\mathrm{NO}_{3}\right)_{2} \cdot \mathrm{xH}_{2} \mathrm{O}$ & 0.19 & 0.76 \\
\hline EDTA, Ethylenediaminetetraacetate & $\mathrm{Na}_{2}$ EDTA & 7.26 & 29.04 \\
\hline HEDTA, n-Hydroxyethylenediamine triacetate & HEDTA & 2.16 & 8.64 \\
\hline Sodium Gluconate & $\mathrm{C}_{6} \mathrm{H}_{11} \mathrm{NaO}_{7}$ & 3.93 & 15.72 \\
\hline Glycolic Acid & $\mathrm{C}_{2} \mathrm{H}_{4} \mathrm{O}_{3}$ & 26.93 & 107.72 \\
\hline Citric Acid Monohydrate & $\mathrm{C}_{6} \mathrm{H}_{8} \mathrm{O}_{7} \mathrm{H}_{2} \mathrm{O}$ & 9.44 & 37.76 \\
\hline Nitrilotriacetic Acid & $\mathrm{C}_{6} \mathrm{H}_{9} \mathrm{NO}_{6}$ & 0.57 & 2.28 \\
\hline Iminodiacetic Acid & $\mathrm{HN}\left(\mathrm{CH}_{2} \mathrm{COOH}\right)_{2}$ & 6.04 & 24.16 \\
\hline Boric Acid & $\mathrm{H}_{3} \mathrm{BO}_{3}$ & 0.20 & 0.80 \\
\hline Sodium Chloride & $\mathrm{NaCl}$ & 5.84 & 23.36 \\
\hline Sodium Fluoride & $\mathrm{NaF}$ & 0.29 & 1.16 \\
\hline Sodium Chromate & $\mathrm{Na}_{2} \mathrm{Cr}_{2} \mathrm{O}_{4}$ & 0.55 & 2.20 \\
\hline Sodium Sulfate & $\mathrm{Na}_{2} \mathrm{SO}_{4}$ & 12.20 & 48.80 \\
\hline \multirow[t]{2}{*}{ Potassium Molybdate } & $\mathrm{K}_{2} \mathrm{MoO}_{4}$ & 0.09 & 0.36 \\
\hline & SUM & 302.49 & 1209.97 \\
\hline
\end{tabular}


RPP-RPT-44463, Rev. 0

\begin{tabular}{|c|c|c|c|}
\hline \multicolumn{4}{|c|}{ In a separate container, mix the following: } \\
\hline Compound & Formula & $\begin{array}{l}\text { Mass }(g) \\
\text { for } 1 \mathrm{~L} \text { of } \\
\text { solution }\end{array}$ & $\begin{array}{l}\text { Mass }(g) \\
\text { for } 4 L \text { of } \\
\text { solution } \\
\end{array}$ \\
\hline Sodium Hydroxide & $\mathrm{NaOH}$ & 15.26 & 61.04 \\
\hline Aluminum Nitrate, 9-Hydrate & $\mathrm{Al}\left(\mathrm{NO}_{3}\right)_{3} .9 \mathrm{H}_{2} \mathrm{O}$ & 5.37 & 21.48 \\
\hline Sodium Phosphate, 12-Hydrate & $\mathrm{Na}_{3} \mathrm{PO}_{4} 12 \mathrm{H}_{2} \mathrm{O}$ & 4.44 & 17.76 \\
\hline Sodium Formate & $\mathrm{NaHCOO}$ & 15.71 & 62.84 \\
\hline Sodium Acetate Trihydrate & $\mathrm{NaCH}_{3} \mathrm{COO} .3 \mathrm{H}_{2} \mathrm{O}$ & 2.37 & 9.48 \\
\hline Sodium Oxalate & $\mathrm{Na}_{2} \mathrm{C}_{2} \mathrm{O}_{4}$ & 1.26 & 5.04 \\
\hline \multirow[t]{2}{*}{ Deionized Water } & $\mathrm{H}_{2} \mathrm{O}$ & 200.00 & 800.00 \\
\hline & SUM & 244.41 & 977.64 \\
\hline \multicolumn{4}{|l|}{ Mix thoroughly. } \\
\hline \multicolumn{4}{|c|}{ Then add the following to the solution in the carboy: } \\
\hline Sodium Carbonate & $\mathrm{Na}_{2} \mathrm{CO}_{3}$ & 148.25 & 593.00 \\
\hline \multicolumn{4}{|l|}{ Mix thoroughly } \\
\hline \multicolumn{4}{|c|}{ Then add the following to the solution in the carboy: } \\
\hline Sodium Nitrate & $\mathrm{NaNO}_{3}$ & 297.29 & 1189.16 \\
\hline Sodium Nitrite & $\mathrm{NaNO}_{2}$ & 82.79 & 331.16 \\
\hline Water & $\mathrm{H}_{2} \mathrm{O}$ & 100.00 & 400.00 \\
\hline Add and mix thoroughly. & SUM & 480.08 & 1920.32 \\
\hline \multicolumn{4}{|c|}{ Mix thoroughly and dilute to the 4-liter mark in the volumetric flask. } \\
\hline & SUM TOTAL & 1175.23 & 4700.93 \\
\hline $\begin{array}{l}\text { Measure the } \mathrm{pH} \text {. Adjust the fi } \\
\text { hydroxide }(\mathrm{NaOH}) \text { up to } 20 \mathrm{~g} \text {. } \\
\text { measure } \mathrm{pH} \text {. }\end{array}$ & $\begin{array}{l}\text { ired } \mathrm{pH} \text { by progre } \\
\text { er each of sodium }\end{array}$ & $\begin{array}{l}\text { vely adding } \\
\text { droxide adc }\end{array}$ & $\begin{array}{l}\text { g of sodium } \\
\text { on and }\end{array}$ \\
\hline
\end{tabular}


RPP-RPT-44463, Rev. 0

APPENDIX B

\section{CALIBRATION DATA}

B-1 
We hereby certify that the below noted unit was properly tested using calibrated equipment traceable to NIST standards. This testing ensures the product meets or exceeds Published Mechanical and Safety Specifications and your satisfaction.

Model: 7306

Serial \#: 1D1010048

\section{$\underline{\text { Test Parameters }}$}

Ambient Temp: 22.795

Test Date: $1 / 18 / 2010$
Operator: controllers

Test Fixture Number: 4

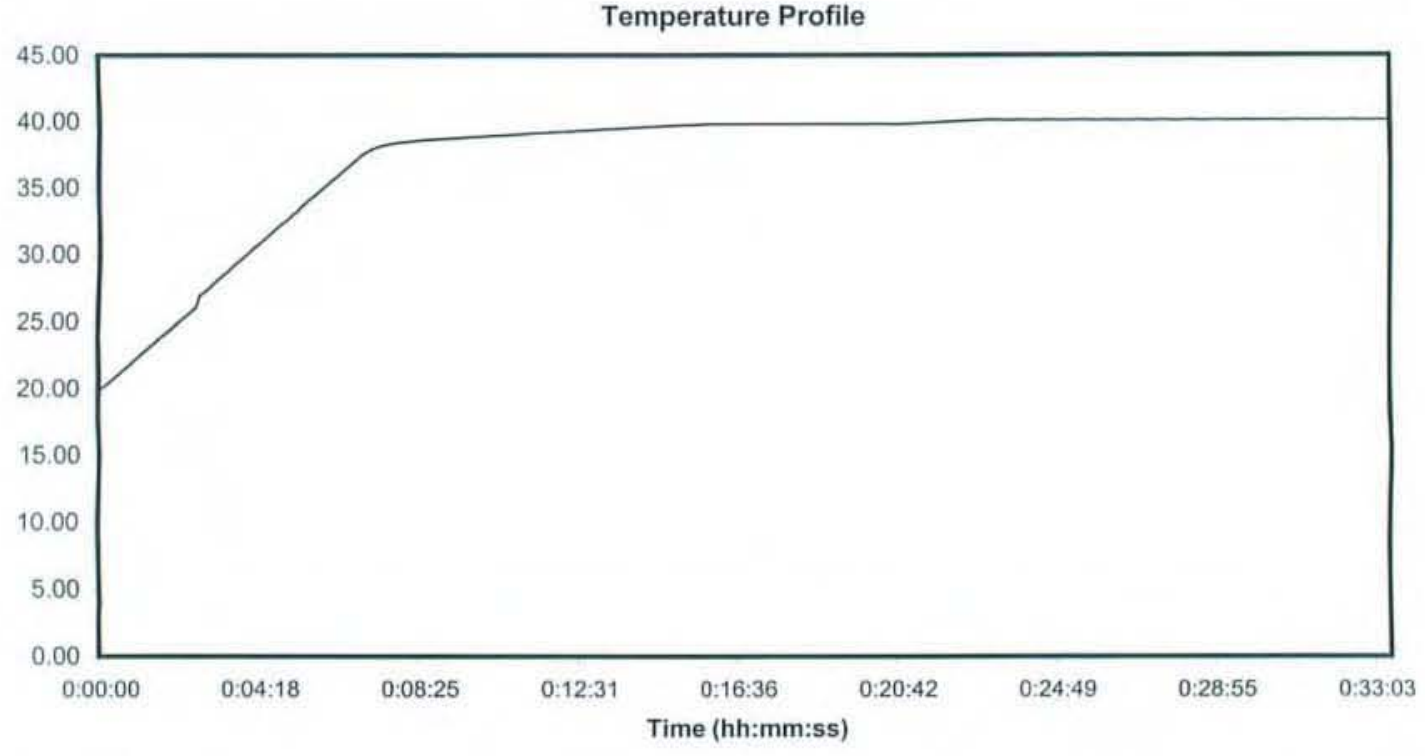

Control System: Verified

Heating System: Verified

Fit \& Finish: Verified
Dialectric Strength Tested: Verified Safety Inspected: Verified Final Inspection: Verified 


\section{Centificate of Compliance}

We hereby certify that the below noted unit was properly tested using calibrated equipment traceable to NIST standards. This testing ensures the product meets or exceeds Published Mechanical and Safety Specifications and your satisfaction.

Model: 7306

Serial \#: 1101D0042

\section{$\underline{\text { Test Parameters }}$}

Ambient Temp: 23.743

Operator: controllers

Test Date: $1 / 14 / 2010$ Test Fixture Number: 2

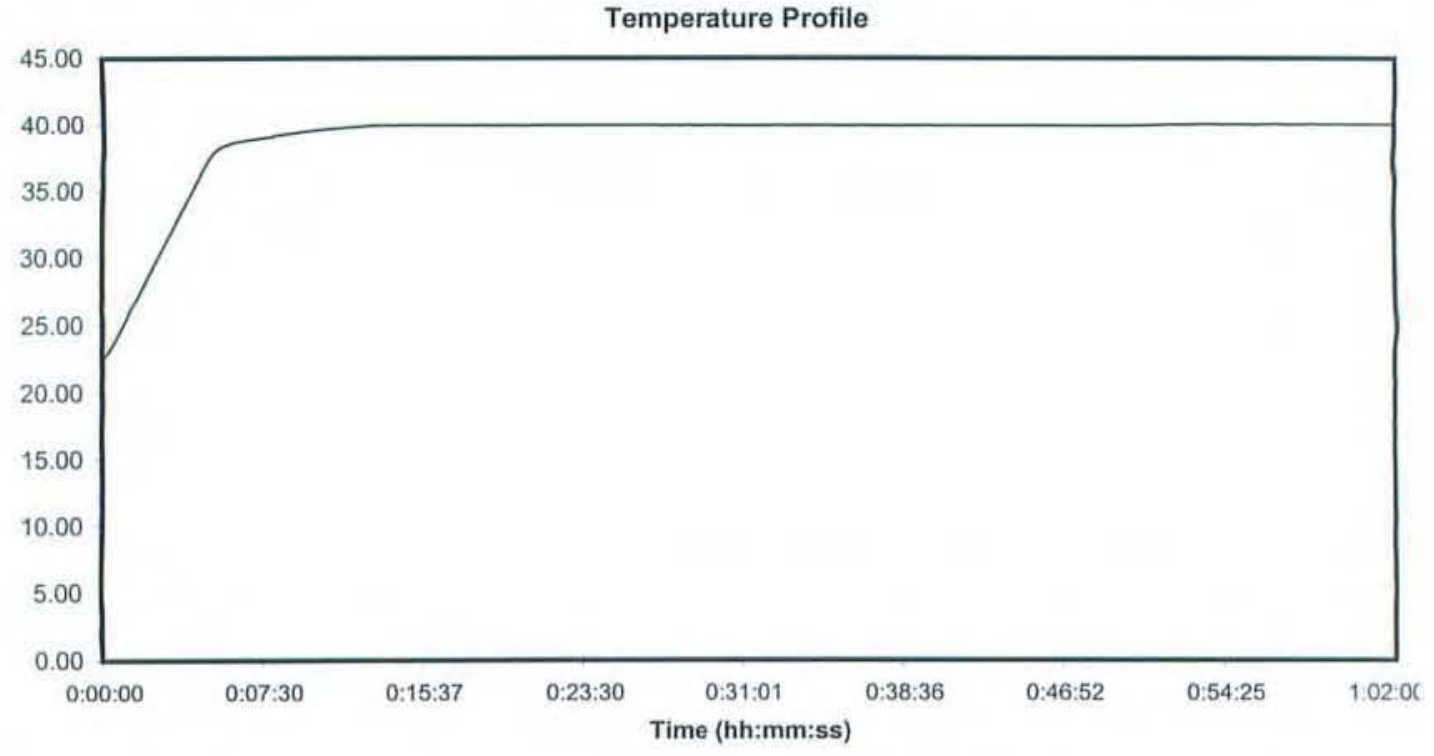

Control System: Verified Heating System: Verified Fit \& Finish: Verified
Dialectric Strength Tested: Verified Safety Inspected: Verified Final Inspection: Verified 
RPP-RPT-44463, Rev. 0

APPENDIX C

DATA SHEETS 
RPP-RPT-44463, Rev. 0

$25^{\circ}$

RPP-PLAN-43915, Rev. 0

241-AY-101 Simulant

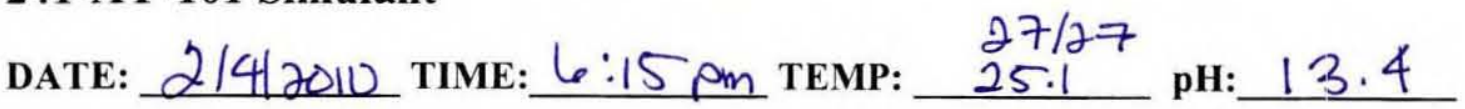

AAR TC128 Electrode vs. Immersed MPCMS Reference Electrodes

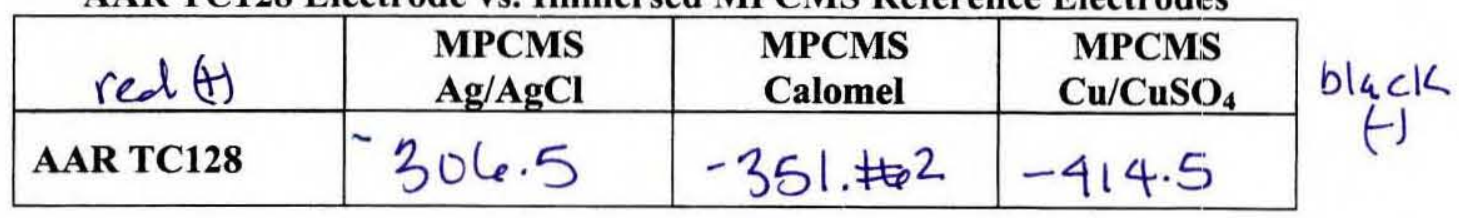

Test Electrodes vs. Room Temperature MPCMS Reference Electrodes

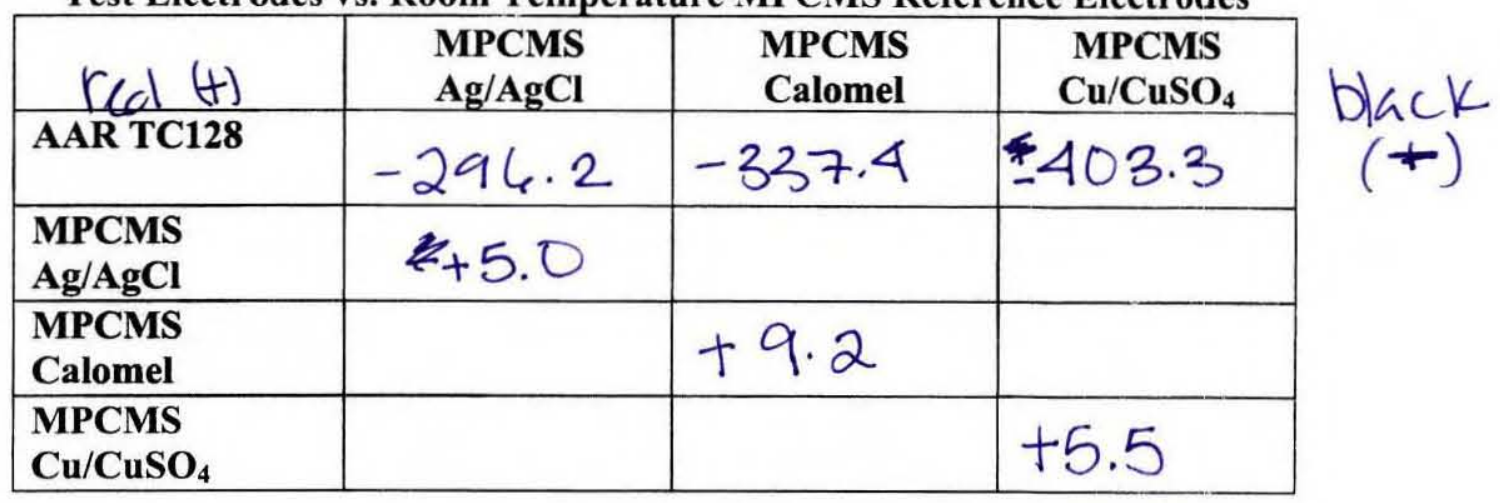

Test Electrodes vs. Room Temperature Laboratory-Grade Reference Electrodes

\begin{tabular}{|l|l|l|l|}
\hline \multicolumn{1}{|c|}{$r(d(t)$} & $\begin{array}{c}\text { Laboratory } \\
\mathbf{A g} / \mathbf{A g C l}\end{array}$ & $\begin{array}{c}\text { Laboratory } \\
\text { Calomel }\end{array}$ & $\begin{array}{c}\text { Laboratory } \\
\text { Cu/CuSO}\end{array}$ \\
\hline AfAR TC128 & -3126 & -341.1 & -411.3 \\
\hline MPCMS Ag/AgCl & -6.8 & & \\
$(-1$
\end{tabular}

* did not shake Cu/CuSO

a.9

This page may be reproduced as necessary.

C-2

Page of

C-2 
RPP-RPT-44463, Rev. 0

RPP-PLAN-43915, Rev. 0

\section{1-AN-107 Simulant}

DATE: $214(20) 0$ TIME:Li, 15 m TEMP: $\begin{aligned} & 27127 \\ & 25.1\end{aligned}$

ASTM A537 Electrode vs. Immersed MPCMS Reference Electrodles

\begin{tabular}{|l|c|c|c|}
\hline & $\begin{array}{c}\text { MPCMS } \\
\text { Ag/AgCl }\end{array}$ & $\begin{array}{c}\text { MPCMS } \\
\text { Calomel }\end{array}$ & $\begin{array}{c}\text { MPCMIS } \\
\text { Cu/CuSO }_{4}\end{array}$ \\
\hline ASTM A537 & -254.0 & $-299^{-2940}$ & -358.0 \\
\hline
\end{tabular}

Test Electrodes vs. Room Temperature MPCMS Reference Electrodes

\begin{tabular}{|l|c|c|c|}
\hline & \multicolumn{1}{|c|}{$\begin{array}{c}\text { MPCMS } \\
\text { Ag/AgCl }\end{array}$} & $\begin{array}{c}\text { MPCMS } \\
\text { Calomel }\end{array}$ & $\begin{array}{c}\text { MPCMS } \\
\text { Cu/CuSO }\end{array}$ \\
\hline ASTM A537 & -248.3 & -289.5 & -355.5 \\
\hline $\begin{array}{l}\text { MPCMS } \\
\text { Ag/AgCl }\end{array}$ & -3.3 & & \\
\hline $\begin{array}{l}\text { MPCMS } \\
\text { Calomel }\end{array}$ & & +2.1 & \\
\hline $\begin{array}{l}\text { MPCMS } \\
\text { Cu/CuSO }\end{array}$ & & & +1.6 \\
\hline
\end{tabular}

Test Electrodes vs. Room Temperature Laboratory-Grade Reference Electrodes

\begin{tabular}{|l|l|l|l|}
\hline & $\begin{array}{c}\text { Laboratory } \\
\text { Ag/AgCl }\end{array}$ & $\begin{array}{c}\text { Laboratory } \\
\text { Calomel }\end{array}$ & $\begin{array}{c}\text { Laboratory } \\
\text { Cu/CuSO }\end{array}$ \\
\hline ASTM A537 & -259.9 & -289.0 & -359.5 \\
\hline $\begin{array}{l}\text { MPCMS } \\
\text { Ag/AgCl }\end{array}$ & -14.5 & & \\
\hline $\begin{array}{l}\text { MPCMS } \\
\text { Calomel }\end{array}$ & & 2.6 & \\
\hline $\begin{array}{l}\text { MPCMS } \\
\text { Cu/CuSO }\end{array}$ & & & -1.3 \\
\hline
\end{tabular}

$\forall$ didnot Skake. $\mathrm{Cu} / \mathrm{CuSO}_{4}$

This page may be reproduced as necessary

C-3

Page 1 of 


$$
\text { RPP-RPT-44463, Rev. } 0
$$

$$
\text { RPP-PLAN-43915, Rev. } 0
$$

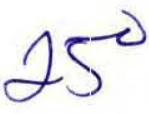

\section{1-AY-101 Simulant}

b-27, 1

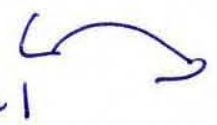

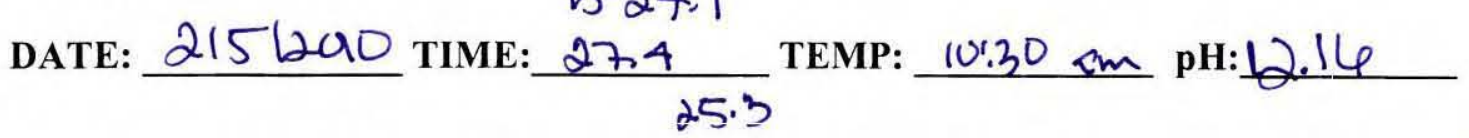

AAR TC128 Electrode vs. Immersed MPCMS Reference Electrodes

\begin{tabular}{|c|c|c|c|}
\hline $\operatorname{Ved}(f)$ & $\begin{array}{c}\text { MPCMS } \\
\text { Ag/AgCI }\end{array}$ & $\begin{array}{c}\text { MPCMS } \\
\text { Calomel }\end{array}$ & $\begin{array}{r}\text { MPCMS } \\
\text { Cu/CuSO }\end{array}$ \\
\hline AAR TC128 & -176.8 & -221.5 & -280.3 \\
\hline
\end{tabular}

Test Electrodes vs. Room Temperature MPCMS Reference Electrodes

\begin{tabular}{|l|l|l|l|}
\hline & \multicolumn{1}{|c|}{$\begin{array}{c}\text { MPCMS } \\
\text { Ag/AgCI }\end{array}$} & $\begin{array}{c}\text { MPCMS } \\
\text { Calomel }\end{array}$ & $\begin{array}{c}\text { MPCMS } \\
\text { Cu/CuSO }\end{array}$ \\
\hline AAR TC128 & $3.8-167.4$ & -209.5 & -277.8 \\
\hline $\begin{array}{l}\text { MPCMS } \\
\text { Ag/AgCl }\end{array}$ & +9.10 & +12.5 & \\
\hline $\begin{array}{l}\text { MPCMS } \\
\text { Calomel }\end{array}$ & & & +2.7 \\
\hline $\begin{array}{l}\text { MPCMS } \\
\text { Cu/CuSO }\end{array}$ & & & \\
\hline
\end{tabular}

Test Electrodes vs. Room Temperature Laboratory-Grade Reference Electrodes

\begin{tabular}{|l|c|l|l|}
\hline & $\begin{array}{c}\text { Laboratory } \\
\text { Ag/AgCl }\end{array}$ & $\begin{array}{c}\text { Laboratory } \\
\text { Calomel }\end{array}$ & $\begin{array}{c}\text { Laboratory } \\
\text { Cu/CuSO4}\end{array}$ \\
\hline AAR TC128 & -179.6 & -207.5 & -271.5 \\
\hline MPCMS Ag/AgCI & -3.1 & & \\
\hline MPCMS Calomel & & +3.7 & +8.5 \\
\hline $\begin{array}{l}\text { MPCMS } \\
\text { Cu/CuSO }_{4}\end{array}$ & & & \\
\hline
\end{tabular}

This page may be reproduced as necessary. 
RPP-RPT-44463, Rev. 0

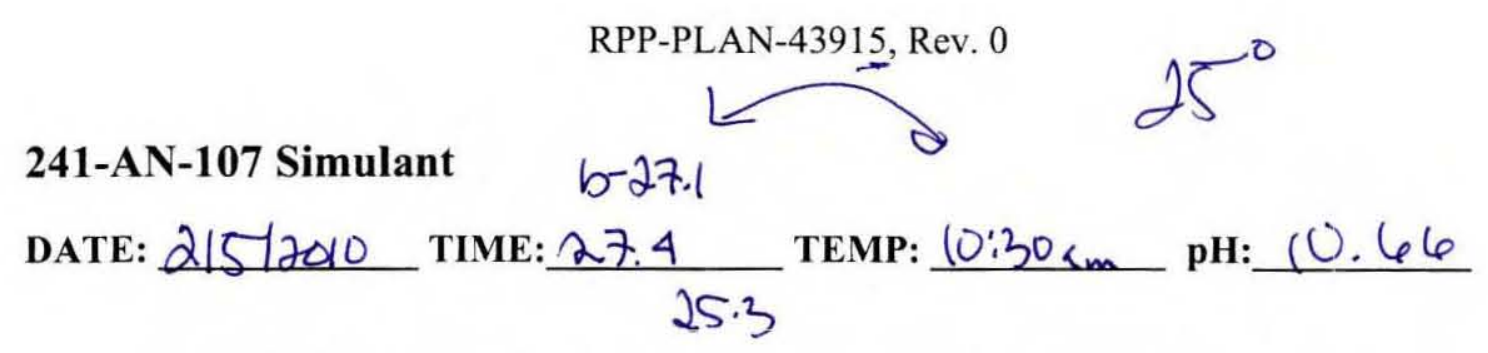

ASTM A537 Electrode vs. Immersed MPCMS Reference Electrodes

\begin{tabular}{|l|c|c|c|}
\hline & $\begin{array}{c}\text { MPCMS } \\
\text { Ag/AgCl }\end{array}$ & $\begin{array}{c}\text { MPCMS } \\
\text { Calomel }\end{array}$ & $\begin{array}{c}\text { MPCMS } \\
\text { Cu/CuSO }_{4}\end{array}$ \\
\hline ASTM A537 & -326.9 & -368.2 & -441.4 \\
\hline
\end{tabular}

Test Electrodes vs. Room Temperature MPCMS Reference Electrodes

\begin{tabular}{|l|l|l|l|}
\hline & $\begin{array}{c}\text { MPCMS } \\
\text { Ag/AgCl }\end{array}$ & $\begin{array}{c}\text { MPCMS } \\
\text { Calomel }\end{array}$ & $\begin{array}{c}\text { MPCMS } \\
\text { Cu/CuSO }\end{array}$ \\
\hline ASTM A537 & -329.2 & -370.9 & -439.5 \\
\hline $\begin{array}{l}\text { MPCMS } \\
\text { Ag/AgCl }\end{array}$ & -4.4 & & \\
\hline $\begin{array}{l}\text { MPCMS } \\
\text { Calomel }\end{array}$ & & -3.9 & \\
\hline $\begin{array}{l}\text { MPCMS } \\
\text { Cu/CuSO }\end{array}$ & & & +3.7 \\
\hline
\end{tabular}

Test Electrodes vs. Room Temperature Laboratory-Grade Reference Electrodes

\begin{tabular}{|l|c|c|c|}
\hline & $\begin{array}{c}\text { Laboratory } \\
\mathbf{A g} / \mathbf{A g C l}\end{array}$ & $\begin{array}{c}\text { Laboratory } \\
\text { Calomel }\end{array}$ & $\begin{array}{c}\text { Laboratory } \\
\mathbf{C u} / \mathbf{C u S O}_{4}\end{array}$ \\
\hline ASTM A537 & -341.5 & -369.9 & -435.2 \\
\hline $\begin{array}{l}\text { MPCMS } \\
\text { Ag/AgCl }\end{array}$ & -16.6 & & \\
\hline $\begin{array}{l}\text { MPCMS } \\
\text { Calomel }\end{array}$ & & -2.6 & +9.5 \\
\hline $\begin{array}{l}\text { MPCMS } \\
\text { Cu/CuSO }\end{array}$ & & & \\
\hline
\end{tabular}

This page may be reproduced as necessary

Page 4 of 
RPP-RPT-44463, Rev. 0

$25^{\circ}$

RPP-PLAN-43915, Rev. 0

241-AY-101 Simulant

$26.9 / 26.8$

DATE: 215 TIME: $12: 30$ pmTEMP: 25 pH: 11.98

AAR TC128 Electrode vs. Immersed MPCMS Reference Electrodes

\begin{tabular}{|l|c|c|c|}
\hline & $\begin{array}{c}\text { MPCMS } \\
\text { Ag/AgCl }\end{array}$ & $\begin{array}{c}\text { MPCMS } \\
\text { Calomel }\end{array}$ & $\begin{array}{c}\text { MPCMS } \\
\text { Cu/CuSO }_{4}\end{array}$ \\
\hline AAR TC128 & -175.2 & -219.7 & -278.3 \\
\hline
\end{tabular}

Test Electrodes vs. Room Temperature MPCMS Reference Electrodes

\begin{tabular}{|l|c|c|c|}
\hline & \multicolumn{1}{|c|}{$\begin{array}{c}\text { MPCMS } \\
\text { Ag/AgCl }\end{array}$} & $\begin{array}{c}\text { MPCMS } \\
\text { Calomel }\end{array}$ & $\begin{array}{c}\text { MPCMS } \\
\mathbf{C u} / \mathbf{C u S O}_{4}\end{array}$ \\
\hline AAR TC128 & -164.6 & -206.4 & -275.7 \\
\hline $\begin{array}{l}\text { MPCMS } \\
\text { Ag/AgCl }\end{array}$ & +9.2 & & \\
\hline $\begin{array}{l}\text { MPCMS } \\
\text { Calomel }\end{array}$ & & +12.2 & \\
\hline $\begin{array}{l}\text { MPCMS } \\
\text { Cu/CuSO }\end{array}$ & & & +1.8 \\
\hline
\end{tabular}

Test Electrodes vs. Room Temperature Laboratory-Grade Reference Electrodes

\begin{tabular}{|l|c|c|c|}
\hline & $\begin{array}{c}\text { Laboratory } \\
\mathbf{A g} / \mathbf{A g C l}\end{array}$ & $\begin{array}{c}\text { Laboratory } \\
\text { Calomel }\end{array}$ & $\begin{array}{c}\text { Laboratory } \\
\text { Cu/CuSO }\end{array}$ \\
\hline AAR TC128 & -176.3 & -205.0 & -274.7 \\
\hline MPCMS Ag/AgCl & -2.5 & & \\
\hline MPCMS Calomel & & +13.4 & \\
\hline $\begin{array}{l}\text { MPCMS } \\
\text { Cu/CuSO }\end{array}$ & & & +2.9 \\
\hline
\end{tabular}

This page may be reproduced as necessary.

C-2

Page 5 of

C-6 
RPP-RPT-44463, Rev. 0

RPP-PLAN-43915, Rev. 0

241-AN-107 Simulant

$$
26.9 / 26.8
$$

DATE:

215

TIME: $12: 30$

TEMP: 25.0

$\mathrm{pH}: 10.58$

ASTM A537 Electrode vs. Immersed MPCMS Reference Electrodes

\begin{tabular}{|l|c|c|c|}
\hline & $\begin{array}{c}\text { MPCMS } \\
\text { Ag/AgCl }\end{array}$ & $\begin{array}{c}\text { MPCMS } \\
\text { Calomel }\end{array}$ & $\begin{array}{c}\text { MPCMIS } \\
\text { Cu/CuSO }\end{array}$ \\
\hline ASTM A537 & -341.9 & -383.1 & $-45 \$ 3.9$ \\
\hline
\end{tabular}

Test Electrodes vs. Room Temperature MPCMS Reference Electrodes

\begin{tabular}{|l|l|l|l|}
\hline & \multicolumn{1}{|c|}{$\begin{array}{c}\text { MPCMS } \\
\text { Ag/AgCl }\end{array}$} & $\begin{array}{c}\text { MPCMS } \\
\text { Calomel }\end{array}$ & $\begin{array}{c}\text { MPCMS } \\
\mathbf{C u} / \text { CuSO }_{4}\end{array}$ \\
\hline ASTM A537 & -344.4 & -306.0 & -454.4 \\
\hline $\begin{array}{l}\text { MPCMS } \\
\text { Ag/AgCl }\end{array}$ & -4.6 & & \\
\hline $\begin{array}{l}\text { MPCMS } \\
\text { Calomel }\end{array}$ & & -4.0 & \\
\hline $\begin{array}{l}\text { MPCMS } \\
\text { Cu/CuSO }\end{array}$ & & & +3.6 \\
\hline
\end{tabular}

Test Electrodes vs. Room Temperature Laboratory-Grade Reference Electrodes

\begin{tabular}{|l|l|l|l|}
\hline & $\begin{array}{c}\text { Laboratory } \\
\text { Ag/AgCl }\end{array}$ & $\begin{array}{c}\text { Laboratory } \\
\text { Calomel }\end{array}$ & $\begin{array}{c}\text { Laboratory } \\
\text { Cu/CuSO }\end{array}$ \\
\hline ASTM A537 & -354.5 & -383.7 & -453.5 \\
\hline $\begin{array}{l}\text { MPCMS } \\
\text { Ag/AgCl }\end{array}$ & -16.1 & & \\
\hline $\begin{array}{l}\text { MPCMS } \\
\text { Calomel }\end{array}$ & & $\$-2.8$ & \\
\hline $\begin{array}{l}\text { MPCMS } \\
\text { Cu/CuSO }_{4}\end{array}$ & & & +4.6 \\
\hline
\end{tabular}

This page may be reproduced as necessary

Page 6 of 
RPP-RPT-44463, Rev. 0

\section{1-AY-101 Simulant}

RPP-PLAN-43915, Rev. 0

DATE: $215 / 200$ TIME: $2: 00 p_{M}$ TEMP: 25.0

AAR TC128 Electrode vs. Immersed MPCMS Reference Electrodes

\begin{tabular}{|l|c|c|c|}
\hline & $\begin{array}{c}\text { MPCMS } \\
\mathbf{A g} / \mathbf{A g C l}\end{array}$ & $\begin{array}{c}\text { MPCMS } \\
\text { Calomel }\end{array}$ & $\begin{array}{c}\text { MPCMS } \\
\mathbf{C u}^{\text {CuSO }}\end{array}$ \\
\hline AAR TC128 & -174.7 & -219.2 & -277.9 \\
\hline
\end{tabular}

Test Electrodes vs. Room Temperature MPCMS Reference Electrodes

\begin{tabular}{|l|l|l|l|}
\hline & \multicolumn{1}{|c|}{$\begin{array}{c}\text { MPCMS } \\
\text { Ag/AgCl }\end{array}$} & $\begin{array}{c}\text { MPCMS } \\
\text { Calomel }\end{array}$ & $\begin{array}{c}\text { MPCMS } \\
\text { Cu/CuSO }\end{array}$ \\
\hline AAR TC128 & -164.3 & -201.2 & -275.9 \\
\hline $\begin{array}{l}\text { MPCMS } \\
\text { Ag/AgCl }\end{array}$ & $t 9.3$ & & \\
\hline $\begin{array}{l}\text { MPCMS } \\
\text { Calomel }\end{array}$ & & +12.2 & \\
\hline $\begin{array}{l}\text { MPCMS } \\
\text { Cu/CuSO }\end{array}$ & & & +1.3 \\
\hline
\end{tabular}

Test Electrodes vs. Room Temperature Laboratory-Grade Reference Electrodes

\begin{tabular}{|l|l|l|l|}
\hline & $\begin{array}{c}\text { Laboratory } \\
\text { Ag/AgCl }\end{array}$ & $\begin{array}{c}\text { Laboratory } \\
\text { Calomel }\end{array}$ & $\begin{array}{c}\text { Laboratory } \\
\text { Cu/CuSO }\end{array}$ \\
\hline AAR TC128 & -177.3 & -205.8 & -275.5 \\
\hline MPCMS Ag/AgCl & -2.4 & & \\
\hline MPCMS Calomel & & +13.4 & +2.6 \\
\hline $\begin{array}{l}\text { MPCMS } \\
\text { Cu/CuSO }\end{array}$ & & \multicolumn{3}{c|}{} \\
\hline
\end{tabular}

This page may be reproduced as necessary.

of 
RPP-RPT-44463, Rev. 0

RPP-PLAN-43915, Rev. 0

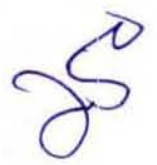

241-AN-107 Simulant

$(20.8)$

DATE: 215 ODIO TIME: 2:02PM TEMP: 25.0 $\mathrm{pH}: \quad 10.60$

ASTM A537 Electrode vs. Immersed MPCMS Reference Electrodes

\begin{tabular}{|l|c|c|c|}
\hline & $\begin{array}{c}\text { MPCMS } \\
\text { Ag/AgCl }\end{array}$ & $\begin{array}{c}\text { MPCMS } \\
\text { Calomel }\end{array}$ & $\begin{array}{c}\text { MPCMS } \\
\text { Cu/CuSO }\end{array}$ \\
\hline ASTM A537 & -346.7 & -388.4 & -461.9 \\
\hline
\end{tabular}

Test Electrodes vs. Room Temperature MPCMS Reference Electrodes

\begin{tabular}{|l|c|c|c|}
\hline & $\begin{array}{c}\text { MPCMS } \\
\text { Ag/AgCl }\end{array}$ & $\begin{array}{c}\text { MPCMS } \\
\text { Calomel }\end{array}$ & $\begin{array}{c}\text { MPCMS } \\
\text { Cu/CuSO }\end{array}$ \\
\hline ASTM A537 & -348.5 & -350.8 & -460.4 \\
\hline $\begin{array}{l}\text { MPCMS } \\
\text { Ag/AgCl }\end{array}$ & -4.5 & & \\
\hline $\begin{array}{l}\text { MPCMS } \\
\text { Calomel }\end{array}$ & & -4.0 & \\
\hline $\begin{array}{l}\text { MPCMS } \\
\text { Cu/CuSO }\end{array}$ & & & +3.0 \\
\hline
\end{tabular}

Test Electrodes vs. Room Temperature Laboratory-Grade Reference Electrodes

\begin{tabular}{|l|c|c|c|}
\hline & $\begin{array}{c}\text { Laboratory } \\
\text { Ag/AgCI }\end{array}$ & $\begin{array}{c}\text { Laboratory } \\
\text { Calomel }\end{array}$ & $\begin{array}{c}\text { Laboratory } \\
\text { Cu/CuSO }\end{array}$ \\
\hline ASTM A537 & -361.0 & -385.2 & -454.2 \\
\hline $\begin{array}{l}\text { MPCMS } \\
\text { Ag/AgCI }\end{array}$ & -16.2 & & \\
\hline $\begin{array}{l}\text { MPCMS } \\
\text { Calomel }\end{array}$ & & -2.8 & +3.8 \\
\hline $\begin{array}{l}\text { MPCMS } \\
\text { Cu/CuSO }\end{array}$ & & & \\
\hline
\end{tabular}

This page may be reproduced as necessary

Page 8 of 
RPP-RPT-44463, Rev. 0

RPP-PLAN-43915, Rev. 0

\section{1-AY-101 Simulant}

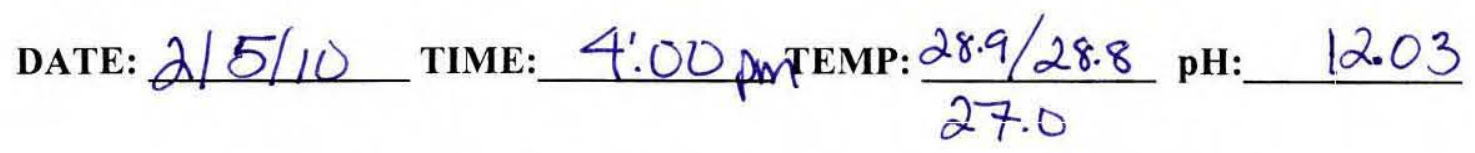

AAR TC128 Electrode vs. Immersed MPCMS Reference Electrodes

\begin{tabular}{|l|c|c|c|}
\hline & $\begin{array}{c}\text { MPCMS } \\
\text { Ag/AgCl }\end{array}$ & $\begin{array}{c}\text { MPCMS } \\
\text { Calomel }\end{array}$ & $\begin{array}{c}\text { MPCMS } \\
\text { Cu/CuSO }\end{array}$ \\
\hline AAR TC128 & -177.0 & $-22 \partial .3$ & $-22 \partial .2$ \\
\hline
\end{tabular}

Test Electrodes vs. Room Temperature MPCMS Reference Electrodes

\begin{tabular}{|l|l|l|l|}
\hline & $\begin{array}{c}\text { MPCMS } \\
\text { Ag/AgCl }\end{array}$ & $\begin{array}{c}\text { MPCMS } \\
\text { Calomel }\end{array}$ & $\begin{array}{c}\text { MPCMS } \\
\text { Cu/CuSO }\end{array}$ \\
\hline AAR TC128 & -167.0 & -204.0 & -278.2 \\
\hline $\begin{array}{l}\text { MPCMS } \\
\text { Ag/AgCl }\end{array}$ & +9.3 & & \\
\hline $\begin{array}{l}\text { MPCMS } \\
\text { Calomel }\end{array}$ & & +13.1 & \\
\hline $\begin{array}{l}\text { MPCMS } \\
\text { Cu/CuSO }\end{array}$ & & & +2.4 \\
\hline
\end{tabular}

Test Electrodes vs. Room Temperature Laboratory-Grade Reference Electrodes

\begin{tabular}{|l|c|c|c|}
\hline & $\begin{array}{c}\text { Laboratory } \\
\text { Ag/AgCl }\end{array}$ & $\begin{array}{c}\text { Laboratory } \\
\text { Calomel }\end{array}$ & $\begin{array}{c}\text { Laboratory } \\
\text { Cu/CuSO }\end{array}$ \\
\hline AAR TC128 & -179.5 & -207.4 & -276.7 \\
\hline MPCMS Ag/AgCl & -2.9 & & \\
\hline MPCMS Calomel & & +14.4 & \\
\hline $\begin{array}{l}\text { MPCMS } \\
\text { Cu/CuSO }_{4}\end{array}$ & & & $\times 5.0$ \\
\hline
\end{tabular}

This page may be reproduced as necessary.

Page 9 of 
RPP-RPT-44463, Rev. 0

RPP-PLAN-43915, Rev. 0

\section{1-AN-107 Simulant}

DATE: $2 / 5 / 10$ TIME: 4:00 pm TEMP: $\frac{28.9 / 28.8}{27.0} \mathrm{pH}: \frac{10.6}{10}$

ASTM A537 Electrode vs. Immersed MPCMS Reference Electrodes

\begin{tabular}{|l|c|c|c|}
\hline & $\begin{array}{c}\text { MPCMS } \\
\text { Ag/AgCl }\end{array}$ & $\begin{array}{c}\text { MPCMS } \\
\text { Calomel }\end{array}$ & $\begin{array}{c}\text { MPCMS } \\
\text { Cu/CuSO }\end{array}$ \\
\hline ASTM A537 & -325.8 & -367.8 & -44.1 \\
\hline
\end{tabular}

Test Electrodes vs. Room Temperature MPCMS Reference Electrodes

\begin{tabular}{|l|c|c|c|}
\hline & $\begin{array}{c}\text { MPCMS } \\
\text { Ag/AgCl }\end{array}$ & $\begin{array}{c}\text { MPCMS } \\
\text { Calomel }\end{array}$ & $\begin{array}{c}\text { MPCMS } \\
\text { Cu/CuSO }\end{array}$ \\
\hline ASTM A537 & -326.5 & -367.5 & -436.2 \\
\hline $\begin{array}{l}\text { MPCMS } \\
\text { Ag/AgCI }\end{array}$ & -4.8 & & \\
\hline $\begin{array}{l}\text { MPCMS } \\
\text { Calomel }\end{array}$ & & -3.6 & \\
\hline $\begin{array}{l}\text { MPCMS } \\
\text { Cu/CuSO }\end{array}$ & & & +3.9 \\
\hline
\end{tabular}

Test Electrodes vs. Room Temperature Laboratory-Grade Reference Electrodes

\begin{tabular}{|l|c|c|c|}
\hline & $\begin{array}{c}\text { Laboratory } \\
\text { Ag/AgCI }\end{array}$ & $\begin{array}{c}\text { Laboratory } \\
\text { Calomel }\end{array}$ & $\begin{array}{c}\text { Laboratory } \\
\text { Cu/CuSO }\end{array}$ \\
\hline ASTM A537 & -336 & -364.0 & -431.2 \\
\hline $\begin{array}{l}\text { MPCMS } \\
\text { Ag/AgCI }\end{array}$ & -16.9 & & \\
\hline $\begin{array}{l}\text { MPCMS } \\
\text { Calomel }\end{array}$ & & -2.4 & \\
\hline $\begin{array}{l}\text { MPCMS } \\
\text { Cu/CuSO }\end{array}$ & & & +6.1 \\
\hline
\end{tabular}

This page may be reproduced as necessary of 
RPP-PLAN-43915, Rev. 0

241-AY-101 Simulant 29.0

DATE: $2 / 5 / 10$

TIME: 5:00 PM

TEMP: 30.3

$\mathrm{pH}: 11.90$

AAR TC128 Electrode vs. Immersed MPCMS Reference Electrodes

\begin{tabular}{|l|l|c|c|}
\hline & $\begin{array}{c}\text { MPCMS } \\
\text { Ag/AgCl }\end{array}$ & $\begin{array}{c}\text { MPCMS } \\
\text { Calomel }\end{array}$ & $\begin{array}{c}\text { MPCMS } \\
\text { Cu/CuSO }_{4}\end{array}$ \\
\hline AAR TC128 & -178.8 & -225.0 & -284.6 \\
\hline
\end{tabular}

Test Electrodes vs. Room Temperature MPCMS Reference Electrodes

\begin{tabular}{|l|c|c|c|}
\hline & $\begin{array}{c}\text { MPCMS } \\
\text { Ag/AgCl }\end{array}$ & $\begin{array}{c}\text { MPCMS } \\
\text { Calomel }\end{array}$ & $\begin{array}{c}\text { MPCMS } \\
\text { Cu/CuSO }\end{array}$ \\
\hline AAR TC128 & -169.0 & -210.4 & -280.1 \\
\hline $\begin{array}{l}\text { MPCMS } \\
\text { Ag/AgCI }\end{array}$ & +9.5 & & \\
\hline $\begin{array}{l}\text { MPCMS } \\
\text { Calomel }\end{array}$ & & +14.0 & \\
\hline $\begin{array}{l}\text { MPCMS } \\
\text { Cu/CuSO }\end{array}$ & & & +3.1 \\
\hline
\end{tabular}

Test Electrodes vs. Room Temperature Laboratory-Grade Reference Electrodes

\begin{tabular}{|l|l|l|l|}
\hline & $\begin{array}{c}\text { Laboratory } \\
\mathbf{A g} / \mathbf{A g C l}\end{array}$ & $\begin{array}{c}\text { Laboratory } \\
\text { Calomel }\end{array}$ & $\begin{array}{c}\text { Laboratory } \\
\mathrm{Cu} / \mathbf{C u S O}_{4}\end{array}$ \\
\hline AAR TC128 & -180.4 & -209.0 & -279.1 \\
\hline MPCMS Ag/AgCl & -2.7 & & \\
\hline MPCMS Calomel & & +15.2 & \\
\hline $\begin{array}{l}\text { MPCMS } \\
\text { Cu/CuSO }\end{array}$ & & & +4.5 \\
\hline
\end{tabular}

This page may be reproduced as necessary.

Page 11 of 


$$
\text { RPP-PLAN-43915, Rev. } 0
$$

241-AN-107 Simulant

DATE: $2 / 5 / 10$ TIME: $5: 00$ PM TEMP: 30.3 $\mathrm{pH}: 10.88$

ASTM A537 Electrode vs. Immersed MPCMS Reference Electrodes

\begin{tabular}{|l|c|c|c|}
\hline & $\begin{array}{c}\text { MPCMS } \\
\text { Ag/AgCl }\end{array}$ & $\begin{array}{c}\text { MPCMS } \\
\text { Calomel }\end{array}$ & $\begin{array}{c}\text { MPCMS } \\
\text { Cu/CuSO }\end{array}$ \\
\hline ASTM A537 & -276.6 & -319.2 & -394.2 \\
\hline
\end{tabular}

Test Electrodes vs. Room Temperature MPCMS Reference Electrodes

\begin{tabular}{|l|l|l|l|}
\hline & \multicolumn{1}{|c|}{$\begin{array}{c}\text { MPCMS } \\
\text { Ag/AgCI }\end{array}$} & $\begin{array}{c}\text { MPCMS } \\
\text { Calomel }\end{array}$ & $\begin{array}{c}\text { MPCMS } \\
\text { Cu/CuSO }\end{array}$ \\
\hline ASTM A537 & -278.2 & -319.6 & -388.2 \\
\hline $\begin{array}{l}\text { MPCMS } \\
\text { Ag/AgCI }\end{array}$ & -4.9 & & \\
\hline $\begin{array}{l}\text { MPCMS } \\
\text { Calomel }\end{array}$ & & -2.9 & +5.3 \\
\hline $\begin{array}{l}\text { MPCMS } \\
\text { Cu/CuSO }\end{array}$ & & & \\
\hline
\end{tabular}

Test Electrodes vs. Room Temperature Laboratory-Grade Reference Electrodes

\begin{tabular}{|l|c|c|c|}
\hline & $\begin{array}{c}\text { Laboratory } \\
\text { Ag/AgCI }\end{array}$ & $\begin{array}{c}\text { Laboratory } \\
\text { Calomel }\end{array}$ & $\begin{array}{c}\text { Laboratory } \\
\text { Cu/CuSO }\end{array}$ \\
\hline ASTM A537 & -286.7 & -314.8 & -384.9 \\
\hline $\begin{array}{l}\text { MPCMS } \\
\text { Ag/AgCl }\end{array}$ & -16.9 & & \\
\hline $\begin{array}{l}\text { MPCMS } \\
\text { Calomel }\end{array}$ & & -1.7 & 6.6 \\
\hline $\begin{array}{l}\text { MPCMS } \\
\text { Cu/CuSO }\end{array}$ & & & 6 \\
\hline
\end{tabular}

This page may be reproduced as necessary of 
RPP-RPT-44463, Rev. 0

RPP-PLAN-43915, Rev. 0

241-AY-101 Simulant $(32.9)$

DATE: TIME: $6: 50$ Pm TEMP: $\frac{32.8}{310}$ $\mathrm{pH}: 11.98$

AAR TC128 Electrode vs. Immersed MPCMS Reference Electrodes

\begin{tabular}{|l|c|c|c|}
\hline & $\begin{array}{c}\text { MPCMS } \\
\mathbf{A g} / \mathbf{A g C l}\end{array}$ & $\begin{array}{c}\text { MPCMS } \\
\text { Calomel }\end{array}$ & $\begin{array}{c}\text { MPCMS } \\
\mathbf{C u}_{\mathbf{C}} \mathbf{C u S O}_{4}\end{array}$ \\
\hline AAR TC128 & 79.6 & -2.74 .7 & -285.5 \\
\hline
\end{tabular}

Test Electrodes vs. Room Temperature MPCMS Reference Electrodes

\begin{tabular}{|l|c|c|c|}
\hline & $\begin{array}{c}\text { MPCMS } \\
\text { Ag/AgCl }\end{array}$ & $\begin{array}{c}\text { MPCMS } \\
\text { Calomel }\end{array}$ & $\begin{array}{c}\text { MPCMS } \\
\text { Cu/CuSO }\end{array}$ \\
\hline AAR TC128 & 16.4 & -211.0 & -280.9 \\
\hline $\begin{array}{l}\text { MPCMS } \\
\text { Ag/AgCl }\end{array}$ & +9.5 & & \\
\hline $\begin{array}{l}\text { MPCMS } \\
\text { Calomel }\end{array}$ & & +15.01 & \\
\hline $\begin{array}{l}\text { MPCMS } \\
\text { Cu/CuSO }\end{array}$ & & & +3.9 \\
\hline
\end{tabular}

Test Electrodes vs. Room Temperature Laboratory-Grade Reference Electrodes

\begin{tabular}{|l|c|c|c|}
\hline & $\begin{array}{c}\text { Laboratory } \\
\mathbf{A g} / \mathbf{A g C l}\end{array}$ & $\begin{array}{c}\text { Laboratory } \\
\text { Calomel }\end{array}$ & $\begin{array}{c}\text { Laboratory } \\
\mathbf{C u} / \mathbf{C u S O}_{4}\end{array}$ \\
\hline AAR TC128 & -1.81 .7 & -2.9 .8 & -2.79 .8 \\
\hline MPCMS Ag/AgCl & -2.9 & & \\
\hline MPCMS Calomel & & +16.3 & \\
\hline $\begin{array}{l}\text { MPCMS } \\
\text { Cu/CuSO }\end{array}$ & & & +5.9 \\
\hline
\end{tabular}

This page may be reproduced as necessary. of 
RPP-RPT-44463, Rev. 0

RPP-PLAN-43915, Rev. 0

\section{1-AN-107 Simulant $\quad 32.8$}

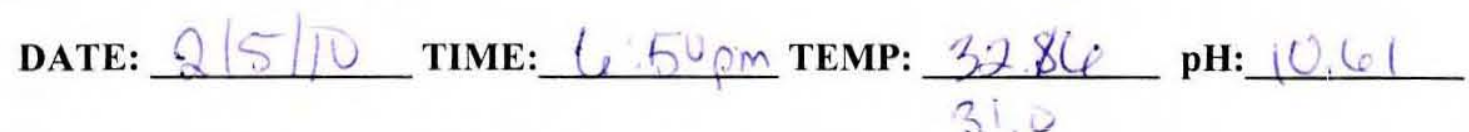
ASTM A537 Electrode vs. Immersed MPCMS Reference Electrodes

\begin{tabular}{|l|c|c|c|}
\hline & $\begin{array}{c}\text { MPCMS } \\
\text { Ag/AgCl }\end{array}$ & $\begin{array}{c}\text { MPCMS } \\
\text { Calomel }\end{array}$ & $\begin{array}{c}\text { MPCMS } \\
\text { Cu/CuSO }\end{array}$ \\
\hline ASTM A537 & -254.1 & -303 & -380.9 \\
\hline
\end{tabular}

Test Electrodes vs. Room Temperature MPCMS Reference Electrodes

\begin{tabular}{|l|c|c|c|}
\hline & $\begin{array}{c}\text { MPCMS } \\
\text { Ag/AgCl }\end{array}$ & $\begin{array}{c}\text { MPCMS } \\
\text { Calomel }\end{array}$ & $\begin{array}{c}\text { MPCMS } \\
\text { Cu/CuSO }\end{array}$ \\
\hline ASTM A537 & -262.9 & -324.3 & -3.737 \\
\hline $\begin{array}{l}\text { MPCMS } \\
\text { Ag/AgCI }\end{array}$ & -51 & & \\
\hline $\begin{array}{l}\text { MPCMS } \\
\text { Calomel }\end{array}$ & & -23 & \\
\hline $\begin{array}{l}\text { MPCMS } \\
\text { Cu/CuSO }\end{array}$ & & & +6.9 \\
\hline
\end{tabular}

Test Electrodes vs. Room Temperature Laboratory-Grade Reference Electrodes

\begin{tabular}{|l|c|c|c|}
\hline & $\begin{array}{c}\text { Laboratory } \\
\text { Ag/AgCI }\end{array}$ & $\begin{array}{c}\text { Laboratory } \\
\text { Calomel }\end{array}$ & $\begin{array}{c}\text { Laboratory } \\
\text { Cu/CuSO }\end{array}$ \\
\hline ASTM A537 & -773.1 & -301.1 & -370.6 \\
\hline $\begin{array}{l}\text { MPCMS } \\
\text { Ag/AgCI }\end{array}$ & -7.7 & & \\
\hline $\begin{array}{l}\text { MPCMS } \\
\text { Calomel }\end{array}$ & & -1.1 & \\
\hline $\begin{array}{l}\text { MPCMS } \\
\text { Cu/CuSO }\end{array}$ & & & +8.7 \\
\hline
\end{tabular}

This page may be reproduced as necessary

C-3

Page 14 of 
RPP-RPT-44463, Rev. 0

RPP-PLAN-43915, Rev. 0

\section{1-AY-101 Simulant}

$(34.9)$

DATE: 5 + $216 / 10$ TIME: $8: 20$ TEMP: $\frac{34.7}{33.0}$ pH: 11.70

AAR TC128 Electrode vs. Immersed MPCMS Reference Electrodes

\begin{tabular}{|c|c|c|c|}
\hline red & $\begin{array}{r}\text { MPCMS } \\
\text { Ag/AgCl }\end{array}$ & $\begin{array}{c}\text { MPCMS } \\
\text { Calomel }\end{array}$ & $\begin{array}{c}\text { MPCMS } \\
\text { Cu/CuSO }\end{array}$ \\
\hline AAR TC128 & -133.3 & -221.0 & -277.6 \\
\hline
\end{tabular}

Test Electrodes vs. Room Temperature MPCMS Reference Electrodes

\begin{tabular}{|l|l|l|l|}
\hline \multicolumn{1}{|c|}{$\begin{array}{c}\text { MPCMS } \\
\mathbf{A g} / \mathrm{AgCl}\end{array}$} & $\begin{array}{c}\text { MPCMS } \\
\text { Calomel }\end{array}$ & $\begin{array}{c}\text { MPCMS } \\
\mathbf{C u} / \mathrm{CuSO}_{4}\end{array}$ \\
\hline AAR TC128 & -162.1 & -204.0 & -275.7 \\
\hline $\begin{array}{l}\text { MPCMS } \\
\text { Ag/AgCl }\end{array}$ & +10.1 & & \\
\hline $\begin{array}{l}\text { MPCMS } \\
\text { Calomel }\end{array}$ & & +16.3 & \\
\hline $\begin{array}{l}\text { MPCMS } \\
\text { Cu/CuSO }\end{array}$ & & & +1.6 \\
\hline
\end{tabular}

Test Electrodes vs. Room Temperature Laboratory-Grade Reference Electrodes

\begin{tabular}{|l|l|l|l|}
\hline & $\begin{array}{c}\text { Laboratory } \\
\mathbf{A g} / \mathbf{A g C l}\end{array}$ & $\begin{array}{c}\text { Laboratory } \\
\text { Calomel }\end{array}$ & $\begin{array}{c}\text { Laboratory } \\
\mathbf{C u} / \mathbf{C u S O}_{4}\end{array}$ \\
\hline AAR TC128 & -175.0 & -202.5 & -270.5 \\
\hline MPCMS Ag/AgCl & -2.8 & & \\
\hline MPCMS Calomel & & +17.5 & \\
\hline $\begin{array}{l}\text { MPCMS } \\
\text { Cu/CuSO }\end{array}$ & & & +6.9 \\
\hline
\end{tabular}

This page may be reproduced as necessary.

Page 15 of 
RPP-RPT-44463, Rev. 0

RPP-PLAN-43915, Rev. 0

241-AN-107 Simulant

$(34.9)$

DATE: $216 / 10$ TIME: $8: 20$ TEMP: $\frac{34.7}{33.0}$ pH: 10.60

ASTM A537 Electrode vs. Immersed MPCMS Reference Electrodes

\begin{tabular}{|l|c|c|c|}
\hline & $\begin{array}{c}\text { MPCMS } \\
\text { Ag/AgCl }\end{array}$ & $\begin{array}{c}\text { MPCMS } \\
\text { Calomel }\end{array}$ & $\begin{array}{c}\text { MPCMS } \\
\text { Cu/CuSO }_{4}\end{array}$ \\
\hline ASTM A537 & -224.0 & -268.1 & -349.0 \\
\hline
\end{tabular}

Test Electrodes vs. Room Temperature MPCMS Reference Electrodes

\begin{tabular}{|l|c|c|c|}
\hline & $\begin{array}{c}\text { MPCMS } \\
\text { Ag/AgCl }\end{array}$ & $\begin{array}{c}\text { MPCMS } \\
\text { Calomel }\end{array}$ & $\begin{array}{c}\text { MPCMS } \\
\text { Cu/CuSO }\end{array}$ \\
\hline ASTM A537 & -226.5 & -267.1 & -338.3 \\
\hline $\begin{array}{l}\text { MPCMS } \\
\text { Ag/AgCI }\end{array}$ & -6.1 & & \\
\hline $\begin{array}{l}\text { MPCMS } \\
\text { Calomel }\end{array}$ & & -3.1 & \\
\hline $\begin{array}{l}\text { MPCMS } \\
\text { Cu/CuSO }\end{array}$ & & & +9.6 \\
\hline
\end{tabular}

Test Electrodes vs. Room Temperature Laboratory-Grade Reference Electrodes

\begin{tabular}{|l|l|l|l|}
\hline & $\begin{array}{c}\text { Laboratory } \\
\text { Ag/AgCl }\end{array}$ & $\begin{array}{c}\text { Laboratory } \\
\text { Calomel }\end{array}$ & $\begin{array}{c}\text { Laboratory } \\
\text { Cu/CuSO }\end{array}$ \\
\hline ASTM A537 & -237.3 & -264.6 & -332.4 \\
\hline $\begin{array}{l}\text { MPCMS } \\
\text { Ag/AgCl }\end{array}$ & -19.1 & & \\
\hline $\begin{array}{l}\text { MPCMS } \\
\text { Calomel }\end{array}$ & & -1.9 & \\
\hline $\begin{array}{l}\text { MPCMS } \\
\text { Cu/CuSO }\end{array}$ & & & +14.7 \\
\hline
\end{tabular}

This page may be reproduced as necessary

C-3

Page 16 of 
RPP-PLAN-43915, Rev. 0

\section{1-AY-101 Simulant}

DATE: $2 / 6 / 10$

TIME: $10: 00$

TEMP: $\quad 36.6$

35.0

$(36.6)$

AAR TC128 Electrode vs. Immersed MPCMS Reference Electrodes

\begin{tabular}{|c|c|c|c|}
\hline & $\begin{array}{l}\text { MPCMS } \\
\text { Ag/AgCl } \\
\end{array}$ & $\begin{array}{l}\text { MPCMS } \\
\text { Calomel }\end{array}$ & $\begin{array}{c}\text { MPCMS } \\
\mathrm{Cu} / \mathrm{CuSO}_{4}\end{array}$ \\
\hline AAR TC128 & -175.2 & -223.8 & -251.0 \\
\hline
\end{tabular}

Test Electrodes vs. Room Temperature MPCMS Reference Electrodes

\begin{tabular}{|l|c|c|c|}
\hline AAR TC128 & $\begin{array}{c}\text { MPCMS } \\
\text { Ag/AgCl }\end{array}$ & $\begin{array}{c}\text { MPCMS } \\
\text { Calomel }\end{array}$ & $\begin{array}{c}\text { MPCMS } \\
\text { Cu/CuSO }\end{array}$ \\
\hline $\begin{array}{l}\text { MPCMS } \\
\text { Ag/AgCl }\end{array}$ & -164.6 & -206.7 & -275.2 \\
\hline $\begin{array}{l}\text { MPCMS } \\
\text { Calomel }\end{array}$ & +10.1 & & \\
\hline $\begin{array}{l}\text { MPCMS } \\
\text { Cu/CuSO }\end{array}$ & & +16.9 & \\
\hline
\end{tabular}

Test Electrodes vs. Room Temperature Laboratory-Grade Reference Electrodes

\begin{tabular}{|l|l|l|l|}
\hline & $\begin{array}{c}\text { Laboratory } \\
\text { Ag/AgCl }\end{array}$ & $\begin{array}{c}\text { Laboratory } \\
\text { Calomel }\end{array}$ & $\begin{array}{c}\text { Laboratory } \\
\text { Cu/CuSO4 }\end{array}$ \\
\hline AAR TC128 & -177.6 & -205.3 & -273.9 \\
\hline MPCMS Ag/AgCl & -2.8 & & \\
\hline MPCMS Calomel & & +18.2 & \\
\hline $\begin{array}{l}\text { MPCMS } \\
\text { Cu/CuSO }\end{array}$ & & & +7.1 \\
\hline
\end{tabular}

This page may be reproduced as necessary.

Page 17 of 
RPP-RPT-44463, Rev. 0

RPP-PLAN-43915, Rev. 0

\section{1-AN-107 Simulant}

$$
35.0
$$

DATE: $2 / 6 / 10$ TIME:

$10: 00$

TEMP: 36.6

$\mathrm{pH}: 10.55$

ASTM A537 Electrode vs. Immersed MPCMS Reference Electrodes

\begin{tabular}{|l|c|c|c|}
\hline & $\begin{array}{c}\text { MPCMS } \\
\text { Ag/AgCl }\end{array}$ & $\begin{array}{c}\text { MPCMS } \\
\text { Calomel }\end{array}$ & $\begin{array}{c}\text { MPCMS } \\
\mathbf{C u}_{\text {CuSO }}\end{array}$ \\
\hline ASTM A537 & -224.1 & -269.0 & -351.5 \\
\hline
\end{tabular}

Test Electrodes vs. Room Temperature MPCMS Reference Electrodes

\begin{tabular}{|l|c|c|c|}
\hline & $\begin{array}{c}\text { MPCMS } \\
\text { Ag/AgCl }\end{array}$ & $\begin{array}{c}\text { MPCMS } \\
\text { Calomel }\end{array}$ & $\begin{array}{c}\text { MPCMS } \\
\text { Cu/CuSO }\end{array}$ \\
\hline ASTM A537 & -228.1 & -26.9 .7 & -340.4 \\
\hline $\begin{array}{l}\text { MPCMS } \\
\text { Ag/AgCl }\end{array}$ & $2-6.3$ & & \\
\hline $\begin{array}{l}\text { MPCMS } \\
\text { Calomel }\end{array}$ & & -2.5 & \\
\hline $\begin{array}{l}\text { MPCMS } \\
\text { Cu/CuSO }\end{array}$ & & & +10.6 \\
\hline
\end{tabular}

Test Electrodes vs. Room Temperature Laboratory-Grade Reference Electrodes

\begin{tabular}{|l|l|l|l|}
\hline & $\begin{array}{c}\text { Laboratory } \\
\text { Ag/AgCl }\end{array}$ & $\begin{array}{c}\text { Laboratory } \\
\text { Calomel }\end{array}$ & $\begin{array}{c}\text { Laboratory } \\
\text { Cu/CuSO }\end{array}$ \\
\hline ASTM A537 & -239.1 & -266.2 & -334.7 \\
\hline $\begin{array}{l}\text { MPCMS } \\
\text { Ag/AgCl }\end{array}$ & -19.0 & & \\
\hline $\begin{array}{l}\text { MPCMS } \\
\text { Calomel }\end{array}$ & & -1.2 & \\
\hline $\begin{array}{l}\text { MPCMS } \\
\text { Cu/CuSO }\end{array}$ & & & +15.3 \\
\hline
\end{tabular}

This page may be reproduced as necessary of 
RPP-RPT-44463, Rev. 0

RPP-PLAN-43915, Rev. 0

241-AY-101 Simulant

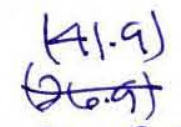

DATE: 216110 TIME: $1: 50 \mathrm{pm}$ TEMP: $\frac{26.9465}{40^{\circ}} \mathrm{pH}: 11.77$

AAR TC128 Electrode vs. Immersed MPCMS Reference Electrodes

\begin{tabular}{|l|c|c|c|}
\hline & $\begin{array}{r}\text { MPCMS } \\
\text { Ag/AgCl }\end{array}$ & $\begin{array}{c}\text { MPCMS } \\
\text { Calomel }\end{array}$ & $\begin{array}{r}\text { MPCMS } \\
\mathbf{C u}_{\text {CuSO }}\end{array}$ \\
\hline AAR TC128 & -183.0 & -234.1 & -288.9 \\
\hline
\end{tabular}

Test Electrodes vs. Room Temperature MPCMS Reference Electrodes

\begin{tabular}{|l|c|c|c|}
\hline & $\begin{array}{c}\text { MPCMS } \\
\text { Ag/AgCl }\end{array}$ & $\begin{array}{c}\text { MPCMS } \\
\text { Calomel }\end{array}$ & $\begin{array}{c}\text { MPCMS } \\
\text { Cu/CuSO }\end{array}$ \\
\hline AAR TC128 & $-2-172.3$ & -214.5 & -286.2 \\
\hline $\begin{array}{l}\text { MPCMS } \\
\text { Ag/AgCl }\end{array}$ & +9.9 & +19.2 & \\
\hline $\begin{array}{l}\text { MPCMS } \\
\text { Calomel }\end{array}$ & & & +2.2 \\
\hline $\begin{array}{l}\text { MPCMS } \\
\text { Cu/CuSO }\end{array}$ & & & \\
\hline
\end{tabular}

Test Electrodes vs. Room Temperature Laboratory-Grade Reference Electrodes

\begin{tabular}{|l|c|c|c|}
\hline & $\begin{array}{c}\text { Laboratory } \\
\mathbf{A g} / \mathbf{A g C l}\end{array}$ & $\begin{array}{c}\text { Laboratory } \\
\text { Calomel }\end{array}$ & $\begin{array}{c}\text { Laboratory } \\
\mathbf{C u} / \mathbf{C u S O}_{4}\end{array}$ \\
\hline AAR TC128 & -184.9 & -213.0 & -283.6 \\
\hline MPCMS Ag/AgCl & -2.8 & & \\
\hline MPCMS Calomel & & +20.4 & \\
\hline $\begin{array}{l}\text { MPCMS } \\
\text { Cu/CuSO }\end{array}$ & & & +5.6 \\
\hline
\end{tabular}

This page may be reproduced as necessary.

C-2

Page 19 of 
241-AN-107 Simulant

DATE: $216 / 10$ TIME: $1: 50 \mathrm{pm}$ TEMP: $\frac{26.841 .5}{40^{\circ}} \mathrm{pH}: 10.49$

ASTM A537 Electrode vs. Immersed MPCMS Reference Electrodes

\begin{tabular}{|l|c|c|c|}
\hline & $\begin{array}{c}\text { MPCMS } \\
\text { Ag/AgCI }\end{array}$ & $\begin{array}{c}\text { MPCMS } \\
\text { Calomel }\end{array}$ & $\begin{array}{c}\text { MPCMS } \\
\mathbf{C u}^{\text {CuSOO }}\end{array}$ \\
\hline ASTM A537 & -231.2 & -279.1 & -363.1 \\
\hline
\end{tabular}

Test Electrodes vs. Room Temperature MPCMS Reference Electrodes

\begin{tabular}{|l|c|c|c|}
\hline & $\begin{array}{c}\text { MPCMS } \\
\text { Ag/AgCl }\end{array}$ & $\begin{array}{c}\text { MPCMS } \\
\text { Calomel }\end{array}$ & $\begin{array}{c}\text { MPCMS } \\
\text { Cu/CuSO }\end{array}$ \\
\hline ASTM A537 & -235.4 & -277.4 & -349.0 \\
\hline $\begin{array}{l}\text { MPCMS } \\
\text { Ag/AgCl }\end{array}$ & -6.6 & & \\
\hline $\begin{array}{l}\text { MPCMS } \\
\text { Calomel }\end{array}$ & & -0.0 & \\
\hline $\begin{array}{l}\text { MPCMS } \\
\text { Cu/CuSO }\end{array}$ & & & +14.1 \\
\hline
\end{tabular}

Test Electrodes vs. Room Temperature Laboratory-Grade Reference Electrodes

\begin{tabular}{|l|c|c|c|}
\hline & $\begin{array}{c}\text { Laboratory } \\
\text { Ag/AgCl }\end{array}$ & $\begin{array}{c}\text { Laboratory } \\
\text { Calomel }\end{array}$ & $\begin{array}{c}\text { Laboratory } \\
\text { Cu/CuSO }\end{array}$ \\
\hline ASTM A537 & -247.1 & -274.8 & -344.6 \\
\hline $\begin{array}{l}\text { MPCMS } \\
\text { Ag/AgCl }\end{array}$ & -19.2 & & \\
\hline $\begin{array}{l}\text { MPCMS } \\
\text { Calomel }\end{array}$ & & +1.2 & \\
\hline $\begin{array}{l}\text { MPCMS } \\
\text { Cu/CuSO }\end{array}$ & & & +17.6 \\
\hline
\end{tabular}

This page may be reproduced as necessary

Page 20 of 
RPP-PLAN-43915, Rev. 0
241-AY-101 Simulant
(46.8) - woth
DATE: $216 \mid 10$
TIME: $6.50 \mathrm{pm}$
TEMP: $\frac{25}{45^{\circ}}$
pH: 11.3

AAR TC128 Electrode vs. Immersed MPCMS Reference Electrodes

\begin{tabular}{|l|c|c|c|}
\hline & $\begin{array}{c}\text { MPCMS } \\
\text { Ag/AgCl }\end{array}$ & $\begin{array}{c}\text { MPCMS } \\
\text { Calomel }\end{array}$ & $\begin{array}{c}\text { MPCMS } \\
\text { Cu/CuSO }\end{array}$ \\
\hline AAR TC128 & -184.1 & -237.5 & -295.1 \\
\hline
\end{tabular}

Test Electrodes vs. Room Temperature MPCMS Reference Electrodes

\begin{tabular}{|l|l|l|l|}
\hline & \multicolumn{1}{|c|}{$\begin{array}{c}\text { MPCMS } \\
\text { Ag/AgCl }\end{array}$} & $\begin{array}{c}\text { MPCMS } \\
\text { Calomel }\end{array}$ & $\begin{array}{c}\text { MPCMS } \\
\text { Cu/CuSO }\end{array}$ \\
\hline AAR TC128 & -173.9 & -216.4 & -288.8 \\
\hline $\begin{array}{l}\text { MPCMS } \\
\text { Ag/AgCl }\end{array}$ & +9.6 & & \\
\hline $\begin{array}{l}\text { MPCMS } \\
\text { Calomel }\end{array}$ & & +21.0 & \\
\hline $\begin{array}{l}\text { MPCMS } \\
\text { Cu/CuSO }\end{array}$ & & & +6.1 \\
\hline
\end{tabular}

Test Electrodes vs. Room Temperature Laboratory-Grade Reference Electrodes

\begin{tabular}{|l|c|c|c|}
\hline & $\begin{array}{c}\text { Laboratory } \\
\text { Ag/AgCl }\end{array}$ & $\begin{array}{c}\text { Laboratory } \\
\text { Calomel }\end{array}$ & $\begin{array}{c}\text { Laboratory } \\
\text { Cu/CuSO }\end{array}$ \\
\hline AAR TC128 & -187.2 & -214.9 & -282.5 \\
\hline MPCMS Ag/AgCl & -3.5 & & \\
\hline MPCMS Calomel & & +22.3 & \\
\hline $\begin{array}{l}\text { MPCMS } \\
\text { Cu/CuSO }\end{array}$ & & & +12.8 \\
\hline
\end{tabular}

This page may be reproduced as necessary.

of 
RPP-PLAN-43915, Rev. 0

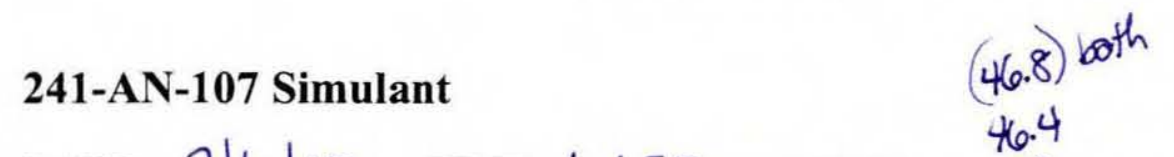

DATE: $216 / 10$ TIME: $6: 50 \mathrm{pm}$ TEMP: $\frac{46^{\circ}}{45^{\circ}} \mathrm{pH}: 10.47$

ASTM A537 Electrode vs. Immersed MPCMS Reference Electrodes

\begin{tabular}{|l|c|c|c|}
\hline & $\begin{array}{c}\text { MPCMS } \\
\text { Ag/AgCl }\end{array}$ & $\begin{array}{c}\text { MPCMS } \\
\text { Calomel }\end{array}$ & $\begin{array}{c}\text { MPCMS } \\
\text { Cu/CuSO }\end{array}$ \\
\hline ASTM A537 & -236.8 & -287.9 & -372.5 \\
\hline
\end{tabular}

Test Electrodes vs. Room Temperature MPCMS Reference Electrodes

\begin{tabular}{|l|c|c|c|}
\hline & $\begin{array}{c}\text { MPCMS } \\
\text { Ag/AgCl }\end{array}$ & $\begin{array}{c}\text { MPCMS } \\
\text { Calomel }\end{array}$ & $\begin{array}{c}\text { MPCMS } \\
\text { Cu/CuSO }\end{array}$ \\
\hline ASTM A537 & -241.9 & -284.2 & -356.1 \\
\hline $\begin{array}{l}\text { MPCMS } \\
\text { Ag/AgCI }\end{array}$ & -7.3 & & \\
\hline $\begin{array}{l}\text { MPCMS } \\
\text { Calomel }\end{array}$ & & +2.3 & +16.1 \\
\hline $\begin{array}{l}\text { MPCMS } \\
\text { Cu/CuSO }\end{array}$ & & & \\
\hline
\end{tabular}

Test Electrodes vs. Room Temperature Laboratory-Grade Reference Electrodes

\begin{tabular}{|l|l|l|l|}
\hline & $\begin{array}{c}\text { Laboratory } \\
\text { Ag/AgCl }\end{array}$ & $\begin{array}{c}\text { Laboratory } \\
\text { Calomel }\end{array}$ & $\begin{array}{c}\text { Laboratory } \\
\text { Cu/CuSO4 }\end{array}$ \\
\hline ASTM A537 & -254.0 & -281.7 & -348.7 \\
\hline $\begin{array}{l}\text { MPCMS } \\
\text { Ag/AgCl }\end{array}$ & -20.2 & & \\
\hline $\begin{array}{l}\text { MPCMS } \\
\text { Calomel }\end{array}$ & & +3.6 & \\
\hline $\begin{array}{l}\text { MPCMS } \\
\text { Cu/CuSO }\end{array}$ & & & +22.9 \\
\hline
\end{tabular}

This page may be reproduced as necessary

Page 22 of 
RPP-RPT-44463, Rev. 0

RPP-PLAN-43915, Rev. 0
241-AY-101 Simulant
50.07 bath

DATE: $2 / 7 / 2010$

TIME: 8:20

TEMP: 57.3

$\mathrm{pH}: 11.80$

AAR TC128 Electrode vs. Immersed MPCMS Reference Electrodes

\begin{tabular}{|l|c|c|c|}
\hline & $\begin{array}{c}\text { MPCMS } \\
\text { Ag/AgCI }\end{array}$ & $\begin{array}{c}\text { MPCMS } \\
\text { Calomel }\end{array}$ & $\begin{array}{c}\text { MPCMS } \\
\text { Cu/CuSO }\end{array}$ \\
\hline AAR TC128 & -168.0 & -222.7 & -283.1 \\
\hline
\end{tabular}

Test Electrodes vs. Room Temperature MPCMS Reference Electrodes

\begin{tabular}{|l|l|l|l|}
\hline \multicolumn{1}{|c|}{$\begin{array}{c}\text { MPCMS } \\
\text { Ag/AgCl }\end{array}$} & $\begin{array}{c}\text { MPCMS } \\
\text { Calomel }\end{array}$ & $\begin{array}{c}\text { MPCMS } \\
\text { Cu/CuSO }\end{array}$ \\
\hline AAR TC128 & -157.3 & -199.4 & -271.9 \\
\hline $\begin{array}{l}\text { MPCMS } \\
\text { Ag/AgCl }\end{array}$ & +9.9 & & \\
\hline $\begin{array}{l}\text { MPCMS } \\
\text { Calomel }\end{array}$ & & +22.7 & \\
\hline $\begin{array}{l}\text { MPCMS } \\
\text { Cu/CuSO }\end{array}$ & & & +10.7 \\
\hline
\end{tabular}

Test Electrodes vs. Room Temperature Laboratory-Grade Reference Electrodes

\begin{tabular}{|l|l|l|l|}
\hline & $\begin{array}{c}\text { Laboratory } \\
\text { Ag/AgCl }\end{array}$ & $\begin{array}{c}\text { Laboratory } \\
\text { Calomel }\end{array}$ & $\begin{array}{c}\text { Laboratory } \\
\text { Cu/CuSO }\end{array}$ \\
\hline AAR TC128 & -170.6 & -197.9 & -262.2 \\
\hline MPCMS Ag/AgCl & -3.6 & & \\
\hline MPCMS Calomel & & +24.0 & \\
\hline $\begin{array}{l}\text { MPCMS } \\
\text { Cu/CuSO }\end{array}$ & & & +19.9 \\
\hline
\end{tabular}

This page may be reproduced as necessary.

C-2

Page 23

of 
RPP-RPT-44463, Rev. 0

RPP-PLAN-43915, Rev. 0

241-AN-107 Simulant

DATE: $2 / 7 / 2010$

TIME: $8: 20$

50.07 boath

TEMP: 51.3

$\mathrm{pH}: 10.41$

ASTM A537 Electrode vs. Immersed MPCMS Reference Electrodes

\begin{tabular}{|l|c|c|c|}
\hline & $\begin{array}{c}\text { MPCMS } \\
\text { Ag/AgCI }\end{array}$ & $\begin{array}{c}\text { MPCMS } \\
\text { Calomel }\end{array}$ & $\begin{array}{c}\text { MPCMS } \\
\text { Cu/CuSO }\end{array}$ \\
\hline ASTM A537 & -237.3 & -290.0 & -377.5 \\
\hline
\end{tabular}

Test Electrodes vs. Room Temperature MPCMS Reference Electrodes

\begin{tabular}{|l|l|l|l|}
\hline & \multicolumn{1}{|c|}{$\begin{array}{c}\text { MPCMS } \\
\text { Ag/AgCl }\end{array}$} & $\begin{array}{c}\text { MPCMS } \\
\text { Calomel }\end{array}$ & $\begin{array}{c}\text { MPCMS } \\
\text { Cu/CuSO }\end{array}$ \\
\hline ASTM A537 & -241.2 & -283.1 & -355.2 \\
\hline $\begin{array}{l}\text { MPCMS } \\
\text { Ag/AgCl }\end{array}$ & -7.6 & & \\
\hline $\begin{array}{l}\text { MPCMS } \\
\text { Calomel }\end{array}$ & & +4.1 & \\
\hline $\begin{array}{l}\text { MPCMS } \\
\text { Cu/CuSO }\end{array}$ & & & +21.1 \\
\hline
\end{tabular}

Test Electrodes vs. Room Temperature Laboratory-Grade Reference Electrodes

\begin{tabular}{|l|l|l|l|}
\hline & $\begin{array}{c}\text { Laboratory } \\
\text { Ag/AgCl }\end{array}$ & $\begin{array}{c}\text { Laboratory } \\
\text { Calomel }\end{array}$ & $\begin{array}{c}\text { Laboratory } \\
\text { Cu/CuSO }\end{array}$ \\
\hline ASTM A537 & -253.8 & -282.1 & -346.3 \\
\hline $\begin{array}{l}\text { MPCMS } \\
\text { Ag/AgCl }\end{array}$ & -20.9 & & \\
\hline $\begin{array}{l}\text { MPCMS } \\
\text { Calomel }\end{array}$ & & +5.3 & \\
\hline $\begin{array}{l}\text { MPCMS } \\
\text { Cu/CuSO }\end{array}$ & & & +30.6 \\
\hline
\end{tabular}

This page may be reproduced as necessary

C-3

Page 24

of 
RPP-PLAN-43915, Rev. 0

241-AY-101 Simulant

DATE: $217 / 10$

TIME: $\underline{1.25} .2 \mathrm{~m}$

TEMP:

$(57.0)$

AAR TC128 Electrode vs. Immersed MPCMS Reference Electrodes

\begin{tabular}{|l|c|c|c|}
\hline & $\begin{array}{c}\text { MPCMS } \\
\mathbf{A g} / \mathbf{A g C l}\end{array}$ & $\begin{array}{c}\text { MPCMS } \\
\text { Calomel }\end{array}$ & $\begin{array}{c}\text { MPCMS } \\
\mathbf{C u}_{\mathbf{C} \text { CuSO }}\end{array}$ \\
\hline AAR TC128 & -174.9 & -231.5 & -289.9 \\
\hline
\end{tabular}

Test Electrodes vs. Room Temperature MPCMS Reference Electrodes

\begin{tabular}{|l|l|l|l|}
\hline & \multicolumn{1}{|c|}{$\begin{array}{c}\text { MPCMS } \\
\text { Ag/AgCl }\end{array}$} & $\begin{array}{c}\text { MPCMS } \\
\text { Calomel }\end{array}$ & $\begin{array}{c}\text { MPCMS } \\
\text { Cu/CuSO }\end{array}$ \\
\hline AAR TC128 & -164.4 & -206.9 & -279.7 \\
\hline $\begin{array}{l}\text { MPCMS } \\
\text { Ag/AgCl }\end{array}$ & +10.0 & & \\
\hline $\begin{array}{l}\text { MPCMS } \\
\text { Calomel }\end{array}$ & & +24.3 & \\
\hline $\begin{array}{l}\text { MPCMS } \\
\text { Cu/CuSO }\end{array}$ & & & +9.9 \\
\hline
\end{tabular}

Test Electrodes vs. Room Temperature Laboratory-Grade Reference Electrodes

\begin{tabular}{|l|l|l|l|}
\hline & $\begin{array}{c}\text { Laboratory } \\
\text { Ag/AgCl }\end{array}$ & $\begin{array}{c}\text { Laboratory } \\
\text { Calomel }\end{array}$ & $\begin{array}{c}\text { Laboratory } \\
\text { Cu/CuSO }\end{array}$ \\
\hline AAR TC128 & -177.0 & -205.4 & -273.6 \\
\hline MPCMS Ag/AgCl & -2.7 & & \\
\hline MPCMS Calomel & & +25.6 & \\
\hline $\begin{array}{l}\text { MPCMS } \\
\text { Cu/CuSO }\end{array}$ & & & +16.0 \\
\hline
\end{tabular}

This page may be reproduced as necessary. of 
241-AN-107 Simulant $(57.0)$

DATE: 217110 TIME: $1: 25$ TEMP: $\frac{55.6}{55.1} \mathrm{pH}: 10.45$

ASTM A537 Electrode vs. Immersed MPCMS Reference Electrodes

\begin{tabular}{|l|c|c|c|}
\hline & $\begin{array}{c}\text { MPCMS } \\
\text { Ag/AgCl }\end{array}$ & $\begin{array}{c}\text { MPCMS } \\
\text { Calomel }\end{array}$ & $\begin{array}{c}\text { MPCMS } \\
\text { Cu/CuSO }_{4}\end{array}$ \\
\hline ASTM A537 & -235.6 & -300.5 & -390.6 \\
\hline
\end{tabular}

Test Electrodes vs. Room Temperature MPCMS Reference Electrodes

\begin{tabular}{|l|c|c|c|}
\hline & $\begin{array}{c}\text { MPCMS } \\
\text { Ag/AgCl }\end{array}$ & $\begin{array}{c}\text { MPCMS } \\
\text { Calomel }\end{array}$ & $\begin{array}{c}\text { MPCMS } \\
\text { Cu/CuSO }\end{array}$ \\
\hline ASTM A537 & -251.1 & -293.3 & -365.7 \\
\hline $\begin{array}{l}\text { MPCMS } \\
\text { Ag/AgCl }\end{array}$ & -7.7 & & \\
\hline $\begin{array}{l}\text { MPCMS } \\
\text { Calomel }\end{array}$ & & +5.5 & \\
\hline $\begin{array}{l}\text { MPCMS } \\
\text { Cu/CuSO }_{4}\end{array}$ & & & 23.6 \\
\hline
\end{tabular}

Test Electrodes vs. Room Temperature Laboratory-Grade Reference Electrodes

\begin{tabular}{|l|c|c|c|}
\hline & $\begin{array}{c}\text { Laboratory } \\
\text { Ag/AgCl }\end{array}$ & $\begin{array}{c}\text { Laboratory } \\
\text { Calomel }\end{array}$ & $\begin{array}{c}\text { Laboratory } \\
\text { Cu/CuSO }\end{array}$ \\
\hline ASTM A537 & 262.3 & -290.2 & -358.5 \\
\hline $\begin{array}{l}\text { MPCMS } \\
\text { Ag/AgCl }\end{array}$ & -20.2 & & \\
\hline $\begin{array}{l}\text { MPCMS } \\
\text { Calomel }\end{array}$ & & +6.8 & \\
\hline $\begin{array}{l}\text { MPCMS } \\
\text { Cu/CuSO }\end{array}$ & & & +30.0 \\
\hline
\end{tabular}

This page may be reproduced as necessary of 
RPP-RPT-44463, Rev. 0

RPP-PLAN-43915, Rev. 0

241-AY-101 Simulant

bath: 61.9

DATE: $2 / 8 / 10$ TIME: 0820 AII TEMP: $\frac{60.1}{\text { heater: } 60} \mathrm{pH}: 11.42$

AAR TC128 Electrode vs. Immersed MPCMS Reference Electrodes

\begin{tabular}{|l|c|c|c|}
\hline & $\begin{array}{l}\text { MPCMS } \\
\mathbf{A g} / \mathbf{A g C l}\end{array}$ & $\begin{array}{c}\text { MPCMS } \\
\text { Calomel }\end{array}$ & $\begin{array}{c}\text { MPCMS } \\
\mathbf{C u}^{\mathbf{C}} \mathbf{C u S O}\end{array}$ \\
\hline AAR TC128 & -205.5 & -262.2 & -317.2 \\
\hline
\end{tabular}

Test Electrodes vs. Room Temperature MPCMS Reference Electrodes

\begin{tabular}{|l|c|c|c|}
\hline & $\begin{array}{c}\text { MPCMS } \\
\mathbf{A g / A g C l}\end{array}$ & $\begin{array}{c}\text { MPCMS } \\
\text { Calomel }\end{array}$ & $\begin{array}{c}\text { MPCMS } \\
\mathbf{C u} / \mathbf{C u S O}_{4}\end{array}$ \\
\hline AAR TC128 & -1931 & -235.4 & -308.6 \\
\hline $\begin{array}{l}\text { MPCMS } \\
\text { Ag/AgCl }\end{array}$ & 10.8 & & \\
\hline $\begin{array}{l}\text { MPCMS } \\
\text { Calomel }\end{array}$ & & 26.15 & \\
\hline $\begin{array}{l}\text { MPCMS } \\
\text { Cu/CuSO }\end{array}$ & & & 8.1 \\
\hline
\end{tabular}

Test Electrodes vs. Room Temperature Laboratory-Grade Reference Electrodes

\begin{tabular}{|l|c|c|c|}
\hline & $\begin{array}{c}\text { Laboratory } \\
\text { Ag/AgCl }\end{array}$ & $\begin{array}{c}\text { Laboratory } \\
\text { Calomel }\end{array}$ & $\begin{array}{c}\text { Laboratory } \\
\text { Cu/CuSO }\end{array}$ \\
\hline AAR TC128 & -206.5 & -233.1 & -297.7 \\
\hline MPCMS Ag/AgCl & -2.5 & & \\
\hline MPCMS Calomel & & 27.34 & \\
\hline $\begin{array}{l}\text { MPCMS } \\
\text { Cu/CuSO }\end{array}$ & & & 19,14 \\
\hline
\end{tabular}

This page may be reproduced as necessary.

C-2

Page

of 


\section{RPP-RPT-44463, Rev. 0}

RPP-PLAN-43915, Rev. 0

241-AN-107 Simulant

bath: 61.9

DATE: $\frac{2 / 8110}{\text { TIME: }} \quad \frac{0826 \text { 4M TEMP: } \frac{60.1}{\text { heake: } 60} \mathrm{pH}:-10.34}{10.34}$

ASTM A537 Electrode vs. Immersed MPCMS Reference Electrodes

\begin{tabular}{|l|c|c|c|}
\hline & $\begin{array}{c}\text { MPCMS } \\
\text { Ag/AgCl }\end{array}$ & $\begin{array}{c}\text { MPCMS } \\
\text { Calomel }\end{array}$ & $\begin{array}{c}\text { MPCMS } \\
\text { Cu/CuSO }_{4}\end{array}$ \\
\hline ASTM A537 & -251.2 & -307.5 & -407.6 \\
\hline
\end{tabular}

Test Electrodes vs. Room Temperature MPCMS Reference Electrodes

\begin{tabular}{|l|c|c|c|}
\hline & $\begin{array}{c}\text { MPCMS } \\
\text { Ag/AgCl }\end{array}$ & $\begin{array}{c}\text { MPCMS } \\
\text { Calomel }\end{array}$ & $\begin{array}{c}\text { MPCMS } \\
\text { Cu/CuSO }\end{array}$ \\
\hline ASTM A537 & -256 & -296.3 & -371.2 \\
\hline $\begin{array}{l}\text { MPCMS } \\
\text { Ag/AgCl }\end{array}$ & -6.9 & & \\
\hline $\begin{array}{l}\text { MPCMS } \\
\text { Calomel }\end{array}$ & & 7.6 & \\
\hline $\begin{array}{l}\text { MPCMS } \\
\text { Cu/CuSO }\end{array}$ & & & 35.68 \\
\hline
\end{tabular}

Test Electrodes vs. Room Temperature Laboratory-Grade Reference Electrodes

\begin{tabular}{|l|c|c|c|}
\hline & $\begin{array}{c}\text { Laboratory } \\
\text { Ag/AgCl }\end{array}$ & $\begin{array}{c}\text { Laboratory } \\
\text { Calomel }\end{array}$ & $\begin{array}{c}\text { Laboratory } \\
\text { Cu/CuSO }\end{array}$ \\
\hline ASTM A537 & -268.4 & -295.7 & -359.1 \\
\hline $\begin{array}{l}\text { MPCMS } \\
\text { Ag/AgCl }\end{array}$ & -20.6 & & \\
\hline $\begin{array}{l}\text { MPCMS } \\
\text { Calomel }\end{array}$ & & 8.7 & \\
\hline $\begin{array}{l}\text { MPCMS } \\
\text { Cu/CuSO }\end{array}$ & & & 46.8 \\
\hline
\end{tabular}

This page may be reproduced as necessary

C-3

Page

of 


$$
\begin{aligned}
& \text { RPP-RPT-44463, Rev. } 0 \\
& \text { RPP-PLAN-43915, Rev. } 0
\end{aligned}
$$

241-AY-101 Simulant

$$
\text { Bath: } 56.9
$$

DATE: $2 / 8 / 10$ TIME: 11:00 AM TEMP: 55.9 $\mathrm{pH}: 11.46$

$$
\text { Set pt: } 55
$$

AAR TC128 Electrode vs. Immersed MPCMS Reference Electrodes

\begin{tabular}{|l|c|c|c|}
\hline & $\begin{array}{c}\text { MPCMS } \\
\text { Ag/AgCl }\end{array}$ & $\begin{array}{c}\text { MPCMS } \\
\text { Calomel }\end{array}$ & $\begin{array}{c}\text { MPCMS } \\
\text { Cu/CuSO }\end{array}$ \\
\hline AAR TC128 & -207.3 & -262.0 & -318.3 \\
\hline
\end{tabular}

Test Electrodes vs. Room Temperature MPCMS Reference Electrodes

\begin{tabular}{|l|c|c|c|}
\hline AAR TC128 & $\begin{array}{c}\text { MPCMS } \\
\text { Ag/AgCl }\end{array}$ & $\begin{array}{c}\text { MPCMS } \\
\text { Calomel }\end{array}$ & $\begin{array}{c}\text { MPCMS } \\
\text { Cu/CuSO }\end{array}$ \\
\hline $\begin{array}{l}\text { MPCMS } \\
\text { Ag/AgCl }\end{array}$ & -144.6 & $-236,8$ & $-309,6$ \\
\hline $\begin{array}{l}\text { MPCMS } \\
\text { Calomel }\end{array}$ & 11.35 & & \\
\hline $\begin{array}{l}\text { MPCMS } \\
\text { Cu/CuSO }\end{array}$ & & 24,2 & \\
\hline
\end{tabular}

Test Electrodes vs. Room Temperature Laboratory-Grade Reference Electrodes

\begin{tabular}{|l|c|c|c|}
\hline & $\begin{array}{c}\text { Laboratory } \\
\text { Ag/AgCl }\end{array}$ & $\begin{array}{c}\text { Laboratory } \\
\text { Calomel }\end{array}$ & $\begin{array}{c}\text { Laboratory } \\
\text { Cu/CuSO }\end{array}$ \\
\hline AAR TC128 & -207.1 & -234.5 & -298.6 \\
\hline MPCMS Ag/AgCl & $-1,7$ & & \\
\hline MPCMS Calomel & & 25.5 & \\
\hline $\begin{array}{l}\text { MPCMS } \\
\text { Cu/CuSO }\end{array}$ & & & 18.6 \\
\hline
\end{tabular}

This page may be reproduced as necessary.

C-2

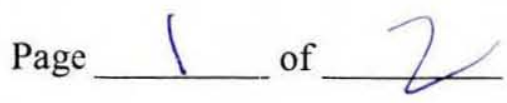


RPP-RPT-44463, Rev. 0

RPP-PLAN-43915, Rev. 0

241-AN-107 Simulant

Bath 56.9

DATE:

$2 / 8 / 10$ TIME:

:11:00 A, 7 TEMP:

55.9

$\mathrm{pH}: 10.28$ SetPt 55

ASTM A537 Electrode vs. Immersed MPCMS Reference Electrodes

\begin{tabular}{|l|c|c|c|}
\hline & $\begin{array}{c}\text { MPCMS } \\
\text { Ag/AgCl }\end{array}$ & $\begin{array}{c}\text { MPCMS } \\
\text { Calomel }\end{array}$ & $\begin{array}{c}\text { MPCMS } \\
\mathbf{C u}^{\text {CuSO }}\end{array}$ \\
\hline ASTM A537 & -2436 & -296.5 & -398.1 \\
\hline
\end{tabular}

Test Electrodes vs. Room Temperature MPCMS Reference Electrodes

\begin{tabular}{|l|c|c|c|}
\hline & $\begin{array}{c}\text { MPCMS } \\
\text { Ag/AgCl }\end{array}$ & $\begin{array}{c}\text { MPCMS } \\
\text { Calomel }\end{array}$ & $\begin{array}{c}\text { MPCMS } \\
\text { Cu/CuSO }\end{array}$ \\
\hline ASTM A537 & -246.3 & -288.2 & 360.6 \\
\hline $\begin{array}{l}\text { MPCMS } \\
\text { Ag/AgCl }\end{array}$ & -6.4 & & \\
\hline $\begin{array}{l}\text { MPCMS } \\
\text { Calomel }\end{array}$ & & 5.3 & \\
\hline $\begin{array}{l}\text { MPCMS } \\
\text { Cu/CuSO }\end{array}$ & & & 35.0 \\
\hline
\end{tabular}

Test Electrodes vs. Room Temperature Laboratory-Grade Reference Electrodes

\begin{tabular}{|l|l|c|c|}
\hline & $\begin{array}{c}\text { Laboratory } \\
\text { Ag/AgCl }\end{array}$ & $\begin{array}{c}\text { Laboratory } \\
\text { Calomel }\end{array}$ & $\begin{array}{c}\text { Laboratory } \\
\text { Cu/CuSO }\end{array}$ \\
\hline ASTM A537 & $-258,3$ & -255.4 & -348.4 \\
\hline $\begin{array}{l}\text { MPCMS } \\
\text { Ag/AgCl }\end{array}$ & -19.8 & & \\
\hline $\begin{array}{l}\text { MPCMS } \\
\text { Calomel }\end{array}$ & & 6.7 & \\
\hline $\begin{array}{l}\text { MPCMS } \\
\text { Cu/CuSO }\end{array}$ & & & 46.2 \\
\hline
\end{tabular}

This page may be reproduced as necessary

C-3

Page 2 of 2 
RPP-RPT-44463, Rev. 0

RPP-PLAN-43915, Rev. 0

241-AY-101 Simulant

Bath: $51.7^{\circ} \mathrm{C}$

DATE: $2 / 8 / 10$ TIME: $1: 30 \mathrm{pm}$ TEMP: $51.4^{\circ} \mathrm{C}$ pH: 11.39 Set pd. $50.0^{\circ} \mathrm{C}$

AAR TC128 Electrode vs. Immersed MPCMS Reference Electrodes

\begin{tabular}{|l|c|c|c|}
\hline & $\begin{array}{c}\text { MPCMS } \\
\text { Ag/AgCI }\end{array}$ & $\begin{array}{c}\text { MPCMS } \\
\text { Calomel }\end{array}$ & $\begin{array}{c}\text { MPCMS } \\
\text { Cu/CuSO }\end{array}$ \\
\hline AAR TC128 & -199.2 & -252.0 & -310.4 \\
\hline
\end{tabular}

Test Electrodes vs. Room Temperature MPCMS Reference Electrodes

\begin{tabular}{|l|c|c|c|}
\hline & $\begin{array}{c}\text { MPCMS } \\
\text { Ag/AgCl }\end{array}$ & $\begin{array}{c}\text { MPCMS } \\
\text { Calomel }\end{array}$ & $\begin{array}{c}\text { MPCMS } \\
\text { Cu/CuSO }\end{array}$ \\
\hline AAR TC128 & -186.8 & -229.5 & -302.4 \\
\hline $\begin{array}{l}\text { MPCMS } \\
\text { Ag/AgCl }\end{array}$ & 11.9 & & \\
\hline $\begin{array}{l}\text { MPCMS } \\
\text { Calomel }\end{array}$ & & 22.3 & \\
\hline $\begin{array}{l}\text { MPCMS } \\
\text { Cu/CuSO }\end{array}$ & & & 6.9 \\
\hline
\end{tabular}

Test Electrodes vs. Room Temperature Laboratory-Grade Reference Electrodes

\begin{tabular}{|l|c|c|c|}
\hline & $\begin{array}{c}\text { Laboratory } \\
\text { Ag/AgCl }\end{array}$ & $\begin{array}{c}\text { Laboratory } \\
\text { Calomel }\end{array}$ & $\begin{array}{c}\text { Laboratory } \\
\text { Cu/CuSO}\end{array}$ \\
\hline AAR TC128 & -201.8 & -229.5 & -293.6 \\
\hline MPCMS Ag/AgCl & -1.4 & & \\
\hline MPCMS Calomel & & 23.6 & \\
\hline $\begin{array}{l}\text { MPCMS } \\
\text { Cu/CuSO }\end{array}$ & & & 18.4 \\
\hline
\end{tabular}

This page may be reproduced as necessary.

C-2

Page 1 of 2 
RPP-RPT-44463, Rev. 0

RPP-PLAN-43915, Rev. 0

241-AN-107 Simulant

Bath: $51.7^{\circ} \mathrm{C}$

DATE: $2 / 8 / 10$

TIME: $1: 30 \mathrm{pm}$

SetT: $\frac{51.4^{\circ} \mathrm{C}}{50.0^{\circ} \mathrm{C}}$ pH: 10.21

ASTM A537 Electrode vs. Immersed MPCMS Reference Electrodes

\begin{tabular}{|l|c|c|c|}
\hline & $\begin{array}{c}\text { MPCMS } \\
\mathbf{A g} / \mathbf{A g C l}\end{array}$ & $\begin{array}{c}\text { MPCMS } \\
\text { Calomel }\end{array}$ & $\begin{array}{c}\text { MPCMS } \\
\mathbf{C u}_{\text {CuSO }}\end{array}$ \\
\hline ASTM A537 & -218.7 & -271.9 & -372.5 \\
\hline
\end{tabular}

Test Electrodes vs. Room Temperature MPCMS Reference Electrodes

\begin{tabular}{|l|c|c|c|}
\hline & $\begin{array}{c}\text { MPCMS } \\
\text { Ag/AgCl }\end{array}$ & $\begin{array}{c}\text { MPCMS } \\
\text { Calomel }\end{array}$ & $\begin{array}{c}\text { MPCMS } \\
\text { Cu/CuSO }\end{array}$ \\
\hline ASTM A537 & -223.6 & -266.3 & -339.9 \\
\hline $\begin{array}{l}\text { MPCMS } \\
\text { Ag/AgCl }\end{array}$ & -5.9 & & \\
\hline $\begin{array}{l}\text { MPCMS } \\
\text { Calomel }\end{array}$ & & 3.9 & \\
\hline $\begin{array}{l}\text { MPCMS } \\
\text { Cu/CuSO }\end{array}$ & & & 33.3 \\
\hline
\end{tabular}

Test Electrodes vs. Room Temperature Laboratory-Grade Reference Electrodes

\begin{tabular}{|l|c|c|c|}
\hline & $\begin{array}{c}\text { Laboratory } \\
\text { Ag/AgCl }\end{array}$ & $\begin{array}{c}\text { Laboratory } \\
\text { Calomel }\end{array}$ & $\begin{array}{c}\text { Laboratory } \\
\text { Cu/CuSO }\end{array}$ \\
\hline ASTM A537 & -239.2 & -266.8 & -330.4 \\
\hline $\begin{array}{l}\text { MPCMS } \\
\text { Ag/AgCl }\end{array}$ & -19.4 & & \\
\hline $\begin{array}{l}\text { MPCMS } \\
\text { Calomel }\end{array}$ & & 5.2 & \\
\hline $\begin{array}{l}\text { MPCMS } \\
\text { Cu/CuSO }_{4}\end{array}$ & & & 44.1 \\
\hline
\end{tabular}

This page may be reproduced as necessary

C-3

Page 2 of 2 
RPP-RPT-44463, Rev. 0

RPP-PLAN-43915, Rev. 0

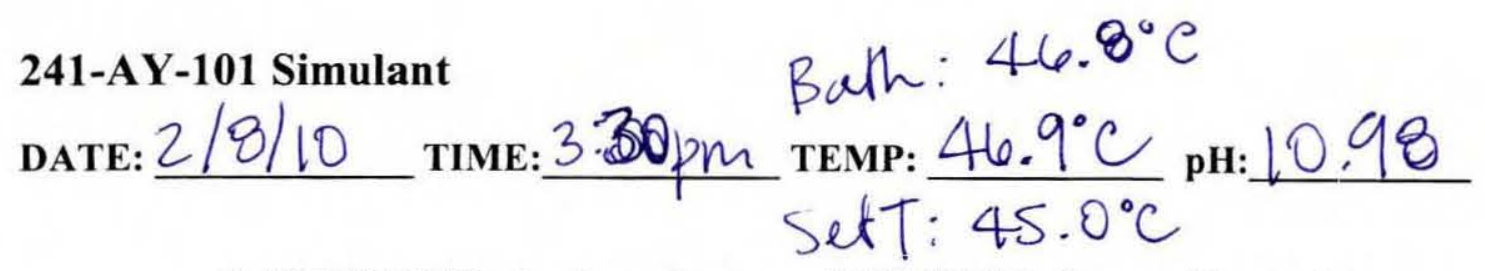

AAR TC128 Electrode vs. Immersed MPCMS Reference Electrodes

\begin{tabular}{|l|c|c|c|}
\hline & $\begin{array}{c}\text { MPCMS } \\
\text { Ag/AgCl }\end{array}$ & $\begin{array}{c}\text { MPCMS } \\
\text { Calomel }\end{array}$ & $\begin{array}{c}\text { MPCMS } \\
\text { Cu/CuSO }\end{array}$ \\
\hline AAR TC128 & -269.4 & -319.3 & -377.8 \\
\hline
\end{tabular}

Test Electrodes vs. Room Temperature MPCMS Reference Electrodes

\begin{tabular}{|l|c|c|c|}
\hline & $\begin{array}{c}\text { MPCMS } \\
\text { Ag/AgCl }\end{array}$ & $\begin{array}{c}\text { MPCMS } \\
\text { Calomel }\end{array}$ & $\begin{array}{c}\text { MPCMS } \\
\text { Cu/CuSO }\end{array}$ \\
\hline AAR TC128 & -254.5 & -296.6 & -368.9 \\
\hline $\begin{array}{l}\text { MPCMS } \\
\text { Ag/AgCl }\end{array}$ & 12.4 & & \\
\hline $\begin{array}{l}\text { MPCMS } \\
\text { Calomel }\end{array}$ & & 20.7 & \\
\hline $\begin{array}{l}\text { MPCMS } \\
\text { Cu/CuSO }\end{array}$ & & & 6.6 \\
\hline
\end{tabular}

Test Electrodes vs. Room Temperature Laboratory-Grade Reference Electrodes

\begin{tabular}{|l|c|c|c|}
\hline & $\begin{array}{c}\text { Laboratory } \\
\text { Ag/AgCI }\end{array}$ & $\begin{array}{c}\text { Laboratory } \\
\text { Calomel }\end{array}$ & $\begin{array}{c}\text { Laboratory } \\
\text { Cu/CuSO }\end{array}$ \\
\hline AAR TC128 & -265.5 & -292.9 & -359.5 \\
\hline MPCMS Ag/AgCI & -0.5 & & \\
\hline MPCMS Calomel & & -7.22 .0 & \\
\hline $\begin{array}{l}\text { MPCMS } \\
\text { Cu/CuSO }_{4}\end{array}$ & & & 14.4 \\
\hline
\end{tabular}

This page may be reproduced as necessary.

C-2

Page 1 of 2 
RPP-RPT-44463, Rev. 0

RPP-PLAN-43915, Rev. 0

241-AN-107 Simulant

Bath: $46.8^{\circ} \mathrm{C}$

DATE: $2 / 8 / 10$ TIME: $3: 30$ pm.

TEMP: $46.9^{\circ} \mathrm{C}$

$\mathrm{pH}: 10.1$ Set $T: 45.0^{\circ} \mathrm{C}$

ASTM A537 Electrode vs. Immersed MPCMS Reference Electrodes

\begin{tabular}{|l|c|c|c|}
\hline & $\begin{array}{c}\text { MPCMS } \\
\text { Ag/AgCI }\end{array}$ & $\begin{array}{c}\text { MPCMS } \\
\text { Calomel }\end{array}$ & $\begin{array}{c}\text { MPCMS } \\
\text { Cu/CuSO }\end{array}$ \\
\hline ASTM A537 & -266.6 & -315.6 & -415 \\
\hline
\end{tabular}

Test Electrodes vs. Room Temperature MPCMS Reference Electrodes

\begin{tabular}{|l|c|c|c|}
\hline & $\begin{array}{c}\text { MPCMS } \\
\text { Ag/AgCl }\end{array}$ & $\begin{array}{c}\text { MPCMS } \\
\text { Calomel }\end{array}$ & $\begin{array}{c}\text { MPCMS } \\
\text { Cu/CuSO }\end{array}$ \\
\hline ASTM A537 & -268.3 & -310.1 & -382.2 \\
\hline $\begin{array}{l}\text { MPCMS } \\
\text { Ag/AgCI }\end{array}$ & -5.8 & & \\
\hline $\begin{array}{l}\text { MPCMS } \\
\text { Calomel }\end{array}$ & & 2.3 & \\
\hline $\begin{array}{l}\text { MPCMS } \\
\text { Cu/CuSO }\end{array}$ & & & 30.9 \\
\hline
\end{tabular}

Test Electrodes vs. Room Temperature Laboratory-Grade Reference Electrodes

\begin{tabular}{|l|c|c|c|}
\hline & $\begin{array}{c}\text { Laboratory } \\
\text { Ag/AgCl }\end{array}$ & $\begin{array}{c}\text { Laboratory } \\
\text { Calomel }\end{array}$ & $\begin{array}{c}\text { Laboratory } \\
\text { Cu/CuSO }\end{array}$ \\
\hline ASTM A537 & -281.5 & -308.5 & -374.2 \\
\hline $\begin{array}{l}\text { MPCMS } \\
\text { Ag/AgCl }\end{array}$ & -18.8 & & \\
\hline $\begin{array}{l}\text { MPCMS } \\
\text { Calomel }\end{array}$ & & 3.6 & \\
\hline $\begin{array}{l}\text { MPCMS } \\
\text { Cu/CuSO }\end{array}$ & & & 39.0 \\
\hline
\end{tabular}

This page may be reproduced as necessary

C-3

Page 2 of 2 
RPP-RPT-44463, Rev. 0

RPP-PLAN-43915, Rev. 0

241-AY-101 Simulant

DATE: $2 / 8110$ TIME: $5: 30 \mathrm{pm}$

AAR TC128 Electrode vs. Immersed MPCMS Reference Electrodes

\begin{tabular}{|l|c|c|c|}
\hline & $\begin{array}{c}\text { MPCMS } \\
\text { Ag/AgCl }\end{array}$ & $\begin{array}{c}\text { MPCMS } \\
\text { Calomel }\end{array}$ & $\begin{array}{c}\text { MPCMS } \\
\text { Cu/CuSO }\end{array}$ \\
\hline AAR TC128 & -304.4 & -352.2 & -412.2 \\
\hline
\end{tabular}

Test Electrodes vs. Room Temperature MPCMS Reference Electrodes

\begin{tabular}{|l|c|c|c|}
\hline & $\begin{array}{c}\text { MPCMS } \\
\text { Ag/AgCl }\end{array}$ & $\begin{array}{c}\text { MPCMS } \\
\text { Calomel }\end{array}$ & $\begin{array}{c}\text { MPCMS } \\
\text { Cu/CuSO }\end{array}$ \\
\hline AAR TC128 & -290.5 & -332.9 & -405.9 \\
\hline $\begin{array}{l}\text { MPCMS } \\
\text { Ag/AgCl }\end{array}$ & 12.8 & & \\
\hline $\begin{array}{l}\text { MPCMS } \\
\text { Calomel }\end{array}$ & & 18.7 & \\
\hline $\begin{array}{l}\text { MPCMS } \\
\text { Cu/CuSO }\end{array}$ & & & $4.6 \%$ \\
\hline
\end{tabular}

Test Electrodes vs. Room Temperature Laboratory-Grade Reference Electrodes

\begin{tabular}{|l|c|c|c|}
\hline & $\begin{array}{c}\text { Laboratory } \\
\text { Ag/AgCl }\end{array}$ & $\begin{array}{c}\text { Laboratory } \\
\text { Calomel }\end{array}$ & $\begin{array}{c}\text { Laboratory } \\
\text { Cu/CuSO }\end{array}$ \\
\hline AAR TC128 & -304.6 & -331.4 & -397.9 \\
\hline MPCMS Ag/AgCl & -0.2 & & \\
\hline MPCMS Calomel & & 19.9 & 12.8 \\
\hline $\begin{array}{l}\text { MPCMS } \\
\text { Cu/CuSO }\end{array}$ & & & \\
\hline
\end{tabular}

This page may be reproduced as necessary.

C-2

Page of

C-36 
RPP-RPT-44463, Rev. 0

RPP-PLAN-43915, Rev. 0

241-AN-107 Simulant

DATE: $2|8|) 0$ тіме: $5: 30$ pha темP: $41.7^{\circ} \mathrm{C}$ pH: 10.2

set $T: 400^{\circ} \mathrm{C}$

ASTM A537 Electrode vs. Immersed MPCMS Reference Electrodes

\begin{tabular}{|l|c|c|c|}
\hline & $\begin{array}{c}\text { MPCMS } \\
\text { Ag/AgCl }\end{array}$ & $\begin{array}{c}\text { MPCMS } \\
\text { Calomel }\end{array}$ & $\begin{array}{c}\text { MPCMS } \\
\text { Cu/CuSO }\end{array}$ \\
\hline ASTM A537 & -292.9 & -340.8 & -439.4 \\
\hline
\end{tabular}

Test Electrodes vs. Room Temperature MPCMS Reference Electrodes

\begin{tabular}{|l|c|c|c|}
\hline & $\begin{array}{c}\text { MPCMS } \\
\text { Ag/AgCl }\end{array}$ & $\begin{array}{c}\text { MPCMS } \\
\text { Calomel }\end{array}$ & $\begin{array}{c}\text { MPCMS } \\
\text { Cu/CuSO }\end{array}$ \\
\hline ASTM A537 & -296.1 & -337.4 & -409.8 \\
\hline $\begin{array}{l}\text { MPCMS } \\
\text { Ag/AgCl }\end{array}$ & -5.8 & & \\
\hline $\begin{array}{l}\text { MPCMS } \\
\text { Calomel }\end{array}$ & & 0.8 & \\
\hline $\begin{array}{l}\text { MPCMS } \\
\text { Cu/CuSO }\end{array}$ & & & 28.4 \\
\hline
\end{tabular}

Test Electrodes vs. Room Temperature Laboratory-Grade Reference Electrodes

\begin{tabular}{|l|c|c|c|}
\hline & $\begin{array}{c}\text { Laboratory } \\
\text { Ag/AgCI }\end{array}$ & $\begin{array}{c}\text { Laboratory } \\
\text { Calomel }\end{array}$ & $\begin{array}{c}\text { Laboratory } \\
\text { Cu/CuSO }\end{array}$ \\
\hline ASTM A537 & -308.4 & -335.1 & -400.9 \\
\hline $\begin{array}{l}\text { MPCMS } \\
\text { Ag/AgCl }\end{array}$ & -18.9 & & \\
\hline $\begin{array}{l}\text { MPCMS } \\
\text { Calomel }\end{array}$ & & 2.1 & \\
\hline $\begin{array}{l}\text { MPCMS } \\
\text { Cu/CuSO }\end{array}$ & & & 36.6 \\
\hline
\end{tabular}

This page may be reproduced as necessary

C-3

Page

2 of

2

C-37 
RPP-RPT-44463, Rev. 0

RPP-PLAN-43915, Rev. 0

\section{1-AY-101 Simulant}

36.8

DATE: $2 / 9 / 10$ TIME: $8: 35$ AM TEMP: $\frac{36.7}{35.0}$ pH: 11.25

AAR TC128 Electrode vs. Immersed MPCMS Reference Electrodes

\begin{tabular}{|l|c|c|c|}
\hline & $\begin{array}{c}\text { MPCMS } \\
\text { Ag/AgCl }\end{array}$ & $\begin{array}{c}\text { MPCMS } \\
\text { Calomel }\end{array}$ & $\begin{array}{c}\text { MPCMS } \\
\text { Cu/CuSO }\end{array}$ \\
\hline AAR TC128 & -349.6 & -395.6 & -452.6 \\
\hline
\end{tabular}

Test Electrodes vs. Room Temperature MPCMS Reference Electrodes

\begin{tabular}{|l|c|c|c|}
\hline & $\begin{array}{l}\text { MPCMS } \\
\text { Ag/AgCl }\end{array}$ & $\begin{array}{c}\text { MPCMS } \\
\text { Calomel }\end{array}$ & $\begin{array}{c}\text { MPCMS } \\
\text { Cu/CuSO }\end{array}$ \\
\hline AAR TC128 & -336.2 & -378.2 & -451.2 \\
\hline $\begin{array}{l}\text { MPCMS } \\
\text { Ag/AgCl }\end{array}$ & 12.3 & & \\
\hline $\begin{array}{l}\text { MPCMS } \\
\text { Calomel }\end{array}$ & & 16.7 & 0.04 \\
\hline $\begin{array}{l}\text { MPCMS } \\
\text { Cu/CuSO }\end{array}$ & & & \\
\hline
\end{tabular}

Test Electrodes vs. Room Temperature Laboratory-Grade Reference Electrodes

\begin{tabular}{|l|c|c|c|}
\hline & $\begin{array}{c}\text { Laboratory } \\
\text { Ag/AgCl }\end{array}$ & $\begin{array}{c}\text { Laboratory } \\
\text { Calomel }\end{array}$ & $\begin{array}{c}\text { Laboratory } \\
\text { Cu/CuSO }\end{array}$ \\
\hline AAR TC128 & -349.7 & -377.4 & -440.3 \\
\hline MPCMS Ag/AgCl & -1.3 & & \\
\hline MPCMS Calomel & & 17.9 & \\
\hline $\begin{array}{l}\text { MPCMS } \\
\text { Cu/CuSO }\end{array}$ & & & 11.2 \\
\hline
\end{tabular}

This page may be reproduced as necessary.

C-2

Page

of 
RPP-RPT-44463, Rev. 0

RPP-PLAN-43915, Rev. 0

241-AN-107 Simulant 36.8

DATE: $2 / 9 / 10$ TIME: 8.35 AM TEMP: $\frac{36.7}{35.0}$ pH: 10.01

ASTM A537 Electrode vs. Immersed MPCMS Reference Electrodes

\begin{tabular}{|l|c|c|c|}
\hline & $\begin{array}{c}\text { MPCMS } \\
\text { Ag/AgCl }\end{array}$ & $\begin{array}{c}\text { MPCMS } \\
\text { Calomel }\end{array}$ & $\begin{array}{c}\text { MPCMS } \\
\text { Cu/CuSO }\end{array}$ \\
\hline ASTM A537 & -245.3 & -292.6 & -386.8 \\
\hline
\end{tabular}

Test Electrodes vs. Room Temperature MPCMS Reference Electrodes

\begin{tabular}{|l|c|c|c|}
\hline & $\begin{array}{c}\text { MPCMS } \\
\text { Ag/AgCl }\end{array}$ & $\begin{array}{c}\text { MPCMS } \\
\text { Calomel }\end{array}$ & $\begin{array}{c}\text { MPCMS } \\
\text { Cu/CuSO }\end{array}$ \\
\hline ASTM A537 & -248.8 & -290.3 & -362.1 \\
\hline $\begin{array}{l}\text { MPCMS } \\
\text { Ag/AgCl }\end{array}$ & -6.4 & & \\
\hline $\begin{array}{l}\text { MPCMS } \\
\text { Calomel }\end{array}$ & & -0.01 & \\
\hline $\begin{array}{l}\text { MPCMS } \\
\text { Cu/CuSO }\end{array}$ & & & 23.4 \\
\hline
\end{tabular}

Test Electrodes vs. Room Temperature Laboratory-Grade Reference Electrodes

\begin{tabular}{|l|c|c|c|}
\hline & $\begin{array}{c}\text { Laboratory } \\
\text { Ag/AgCI }\end{array}$ & $\begin{array}{c}\text { Laboratory } \\
\text { Calomel }\end{array}$ & $\begin{array}{c}\text { Laboratory } \\
\text { Cu/CuSO }\end{array}$ \\
\hline ASTM A537 & $\Phi-28.247 .6$ & -288.3 & -360.7 \\
\hline $\begin{array}{l}\text { MPCMS } \\
\text { Ag/AgCl }\end{array}$ & -20.3 & & \\
\hline $\begin{array}{l}\text { MPCMS } \\
\text { Calomel }\end{array}$ & & 1.3 & 34.4 \\
\hline $\begin{array}{l}\text { MPCMS } \\
\text { Cu/CuSO }\end{array}$ & & & \\
\hline
\end{tabular}

This page may be reproduced as necessary

C-3

Page

of 
RPP-RPT-44463, Rev. 0

RPP-PLAN-43915, Rev. 0

241-AY-101 Simulant

$348^{\circ}$

DATE: $24 / 10$ TIME: $10.15 \mathrm{am}$ TEMP: $\frac{34.8}{33.0 \mathrm{C}}$ pH: 11.05

AAR TC128 Electrode vs. Immersed MPCMS Reference Electrodes

\begin{tabular}{|l|c|c|c|}
\hline & $\begin{array}{c}\text { MPCMS } \\
\text { Ag/AgCI }\end{array}$ & $\begin{array}{c}\text { MPCMS } \\
\text { Calomel }\end{array}$ & $\begin{array}{c}\text { MPCMS } \\
\mathbf{C u}^{\text {CuSO }}\end{array}$ \\
\hline AAR TC128 & -347.1 & -392.8 & -449.5 \\
\hline
\end{tabular}

Test Electrodes vs. Room Temperature MPCMS Reference Electrodes

\begin{tabular}{|l|c|c|c|}
\hline & $\begin{array}{c}\text { MPCMS } \\
\mathbf{A g} / \mathbf{A g C l}\end{array}$ & $\begin{array}{c}\text { MPCMS } \\
\text { Calomel }\end{array}$ & $\begin{array}{c}\text { MPCMS } \\
\mathbf{C u} / \text { CuSO }_{4}\end{array}$ \\
\hline AAR TC128 & -334.8 & -377.9 & -450.9 \\
\hline $\begin{array}{l}\text { MPCMS } \\
\text { Ag/AgCl }\end{array}$ & 12.4 & & \\
\hline $\begin{array}{l}\text { MPCMS } \\
\text { Calomel }\end{array}$ & & 16.0 & \\
\hline $\begin{array}{l}\text { MPCMS } \\
\text { Cu/CuSO }_{4}\end{array}$ & & & -0.8 \\
\hline
\end{tabular}

Test Electrodes vs. Room Temperature Laboratory-Grade Reference Electrodes

\begin{tabular}{|l|c|c|c|}
\hline & $\begin{array}{c}\text { Laboratory } \\
\text { Ag/AgCl }\end{array}$ & $\begin{array}{c}\text { Laboratory } \\
\text { Calomel }\end{array}$ & $\begin{array}{c}\text { Laboratory } \\
\text { Cu/CuSO4 }\end{array}$ \\
\hline AAR TC128 & -349.6 & -377.2 & -441.1 \\
\hline MPCMS Ag/AgCl & -1.2 & & \\
\hline MPCMS Calomel & & 17.3 & \\
\hline $\begin{array}{l}\text { MPCMS } \\
\text { Cu/CuSO }\end{array}$ & & & 10.5 \\
\hline
\end{tabular}

This page may be reproduced as necessary. 
RPP-RPT-44463, Rev. 0

RPP-PLAN-43915, Rev. 0

241-AN-107 Simulant

34.8

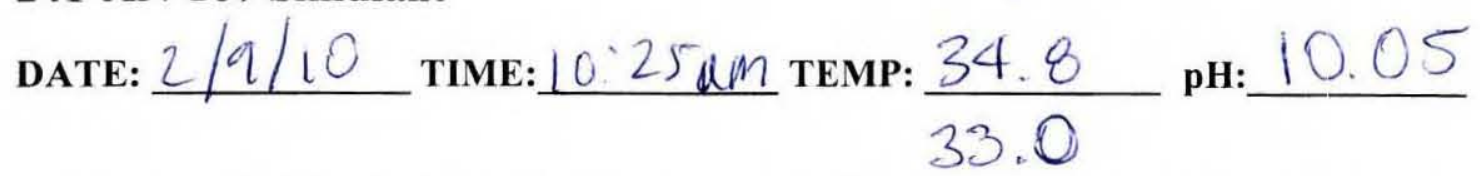

ASTM A537 Electrode vs. Immersed MPCMS Reference Electrodes

\begin{tabular}{|l|c|c|c|}
\hline & $\begin{array}{c}\text { MPCMS } \\
\text { Ag/AgCl }\end{array}$ & $\begin{array}{c}\text { MPCMS } \\
\text { Calomel }\end{array}$ & $\begin{array}{c}\text { MPCMS } \\
\text { Cu/CuSO }\end{array}$ \\
\hline ASTM A537 & -444.2 & -290.4 & -382.4 \\
\hline
\end{tabular}

Test Electrodes vs. Room Temperature MPCMS Reference Electrodes

\begin{tabular}{|l|c|c|c|}
\hline & $\begin{array}{c}\text { MPCMS } \\
\text { Ag/AgCl }\end{array}$ & $\begin{array}{c}\text { MPCMS } \\
\text { Calomel }\end{array}$ & $\begin{array}{c}\text { MPCMS } \\
\text { Cu/CuSO }\end{array}$ \\
\hline ASTM A537 & -245.3 & -286.6 & -358.5 \\
\hline $\begin{array}{l}\text { MPCMS } \\
\text { Ag/AgCl }\end{array}$ & -6.2 & & \\
\hline $\begin{array}{l}\text { MPCMS } \\
\text { Calomel }\end{array}$ & & -0.7 & \\
\hline $\begin{array}{l}\text { MPCMS } \\
\text { Cu/CuSO }\end{array}$ & & & 20.1 \\
\hline
\end{tabular}

Test Electrodes vs. Room Temperature Laboratory-Grade Reference Electrodes

\begin{tabular}{|l|c|c|c|}
\hline & $\begin{array}{c}\text { Laboratory } \\
\text { Ag/AgCl }\end{array}$ & $\begin{array}{c}\text { Laboratory } \\
\text { Calomel }\end{array}$ & $\begin{array}{c}\text { Laboratory } \\
\text { Cu/CuSO }\end{array}$ \\
\hline ASTM A537 & -255.4 & -281.3 & -343.6 \\
\hline $\begin{array}{l}\text { MPCMS } \\
\text { Ag/AgCI }\end{array}$ & -19.9 & & \\
\hline $\begin{array}{l}\text { MPCMS } \\
\text { Calomel }\end{array}$ & & 0.6 & 31.3 \\
\hline $\begin{array}{l}\text { MPCMS } \\
\text { Cu/CuSO }\end{array}$ & & & \\
\hline
\end{tabular}

This page may be reproduced as necessary

C-3

Page 2 of 2 
RPP-RPT-44463, Rev. 0

RPP-PLAN-43915, Rev. 0

241-AY-101 Simulant

$32.86^{\circ} \mathrm{C}$

DATE: $2 / 9 / 10$ TIME: $5.00 \mathrm{pm}$ TEMP: $\frac{32.7^{\circ}}{31.0^{\circ} \mathrm{C}}$ pH: 11.68

AAR TC128 Electrode vs. Immersed MPCMS Reference Electrodes

\begin{tabular}{|l|c|c|c|}
\hline & $\begin{array}{c}\text { MPCMS } \\
\mathbf{A g} / \mathbf{A g C l}\end{array}$ & $\begin{array}{c}\text { MPCMS } \\
\text { Calomel }\end{array}$ & $\begin{array}{c}\text { MPCMS } \\
\mathbf{C u} / \mathbf{C u S O}_{4}\end{array}$ \\
\hline AAR TC128 & -348.0 & -392.8 & -448.3 \\
\hline
\end{tabular}

Test Electrodes vs. Room Temperature MPCMS Reference Electrodes

\begin{tabular}{|l|c|c|c|}
\hline & $\begin{array}{c}\text { MPCMS } \\
\text { Ag/AgCI }\end{array}$ & $\begin{array}{c}\text { MPCMS } \\
\text { Calomel }\end{array}$ & $\begin{array}{c}\text { MPCMS } \\
\text { Cu/CuSO }\end{array}$ \\
\hline AAR TC128 & -334.3 & -377.0 & -449.7 \\
\hline $\begin{array}{l}\text { MPCMS } \\
\text { Ag/AgCI }\end{array}$ & 12.1 & & \\
\hline $\begin{array}{l}\text { MPCMS } \\
\text { Calomel }\end{array}$ & & 15.2 & \\
\hline $\begin{array}{l}\text { MPCMS } \\
\text { Cu/CuSO }\end{array}$ & & & -2.8 \\
\hline
\end{tabular}

Test Electrodes vs. Room Temperature Laboratory-Grade Reference Electrodes

\begin{tabular}{|l|c|c|c|}
\hline & $\begin{array}{c}\text { Laboratory } \\
\text { Ag/AgCl }\end{array}$ & $\begin{array}{c}\text { Laboratory } \\
\text { Calomel }\end{array}$ & $\begin{array}{c}\text { Laboratory } \\
\text { Cu/CuSO4 }\end{array}$ \\
\hline AAR TC128 & -347.3 & -374.4 & -437.4 \\
\hline MPCMS Ag/AgCl & -1.4 & & \\
\hline MPCMS Calomel & & 16.5 & \\
\hline $\begin{array}{l}\text { MPCMS } \\
\text { Cu/CuSO }\end{array}$ & & & 9.1 \\
\hline
\end{tabular}

This page may be reproduced as necessary.

C-2

Page

of 
RPP-RPT-44463, Rev. 0

RPP-PLAN-43915, Rev. 0

241-AN-107 Simulant

$32.90^{\circ} \mathrm{C}$

DATE: $2 / 9 / 10$ TIME: $5: 15$ pm TEMP: $\frac{32.7^{\circ} \mathrm{C}}{31.0^{\circ} \mathrm{C}}$ pH: 10.03

ASTM A537 Electrode vs. Immersed MPCMS Reference Electrodes

\begin{tabular}{|l|c|c|c|}
\hline & $\begin{array}{c}\text { MPCMS } \\
\text { Ag/AgCl }\end{array}$ & $\begin{array}{c}\text { MPCMS } \\
\text { Calomel }\end{array}$ & $\begin{array}{c}\text { MPCMS } \\
\text { Cu/CuSO }\end{array}$ \\
\hline ASTM A537 & -250.1 & -295.8 & -377.0 \\
\hline
\end{tabular}

Test Electrodes vs. Room Temperature MPCMS Reference Electrodes

\begin{tabular}{|l|c|c|c|}
\hline & $\begin{array}{c}\text { MPCMS } \\
\text { Ag/AgCl }\end{array}$ & $\begin{array}{c}\text { MPCMS } \\
\text { Calomel }\end{array}$ & $\begin{array}{c}\text { MPCMS } \\
\text { Cu/CuSO }\end{array}$ \\
\hline ASTM A537 & -251.3 & -292.5 & -364.0 \\
\hline $\begin{array}{l}\text { MPCMS } \\
\text { Ag/AgCl }\end{array}$ & -6.5 & & \\
\hline $\begin{array}{l}\text { MPCMS } \\
\text { Calomel }\end{array}$ & & -1.4 & \\
\hline $\begin{array}{l}\text { MPCMS } \\
\text { Cu/CuSO }\end{array}$ & & & 9.4 \\
\hline
\end{tabular}

Test Electrodes vs. Room Temperature Laboratory-Grade Reference Electrodes

\begin{tabular}{|l|c|c|c|}
\hline & $\begin{array}{c}\text { Laboratory } \\
\text { Ag/AgCI }\end{array}$ & $\begin{array}{c}\text { Laboratory } \\
\text { Calomel }\end{array}$ & $\begin{array}{c}\text { Laboratory } \\
\text { Cu/CuSO }\end{array}$ \\
\hline ASTM A537 & -260.9 & -286.7 & -348.6 \\
\hline $\begin{array}{l}\text { MPCMS } \\
\text { Ag/AgCI }\end{array}$ & -20.0 & & \\
\hline $\begin{array}{l}\text { MPCMS } \\
\text { Calomel }\end{array}$ & & -0.1 & 21.3 \\
\hline $\begin{array}{l}\text { MPCMS } \\
\text { Cu/CuSO }\end{array}$ & & & \\
\hline
\end{tabular}

This page may be reproduced as necessary

C-3

Page

of 
RPP-RPT-44463, Rev. 0

RPP-PLAN-43915, Rev. 0

241-AY-101 Simulant

$30.9^{\circ} \mathrm{C}$

DATE: $2 / 10 / 9.30^{\mathrm{AM}}$ TIME: $9: 30 \mathrm{Am}$ TEMP: $\frac{30.7^{\circ} \mathrm{C}}{29.0^{\circ} \mathrm{C}}$ pH: 11.3

AAR TC128 Electrode vs. Immersed MPCMS Reference Electrodes

\begin{tabular}{|l|c|c|c|}
\hline & $\begin{array}{c}\text { MPCMS } \\
\mathbf{A g} / \mathbf{A g C l}\end{array}$ & $\begin{array}{c}\text { MPCMS } \\
\text { Calomel }\end{array}$ & $\begin{array}{c}\text { MPCMS } \\
\mathbf{C u} / \mathbf{C u S O}_{4}\end{array}$ \\
\hline AAR TC128 & -2624 & -307.4 & -363.1 \\
\hline
\end{tabular}

Test Electrodes vs. Room Temperature MPCMS Reference Electrodes

\begin{tabular}{|l|c|c|c|}
\hline & $\begin{array}{c}\text { MPCMS } \\
\text { Ag/AgCl }\end{array}$ & $\begin{array}{c}\text { MPCMS } \\
\text { Calomel }\end{array}$ & $\begin{array}{c}\text { MPCMS } \\
\text { Cu/CuSO }\end{array}$ \\
\hline AAR TC128 & -250.1 & -292.1 & -365.0 \\
\hline $\begin{array}{l}\text { MPCMS } \\
\text { Ag/AgCl }\end{array}$ & 11.2 & & \\
\hline $\begin{array}{l}\text { MPCMS } \\
\text { Calomel }\end{array}$ & & 14.3 & \\
\hline $\begin{array}{l}\text { MPCMS } \\
\text { Cu/CuSO }\end{array}$ & & & -3.1 \\
\hline
\end{tabular}

Test Electrodes vs. Room Temperature Laboratory-Grade Reference Electrodes

\begin{tabular}{|l|c|c|c|}
\hline & $\begin{array}{c}\text { Laboratory } \\
\mathbf{A g} / \mathbf{A g C l}\end{array}$ & $\begin{array}{c}\text { Laboratory } \\
\text { Calomel }\end{array}$ & $\begin{array}{c}\text { Laboratory } \\
\mathbf{C u} / \mathbf{C u S O}_{4}\end{array}$ \\
\hline AAR TC128 & -263.9 & -290.0 & -349.8 \\
\hline MPCMS Ag/AgCl & -3.0 & & \\
\hline MPCMS Calomel & & 15.68 & \\
\hline $\begin{array}{l}\text { MPCMS } \\
\text { Cu/CuSO }\end{array}$ & & & 12.1 \\
\hline
\end{tabular}

This page may be reproduced as necessary.

C-2

Page

of 
RPP-RPT-44463, Rev. 0

RPP-PLAN-43915, Rev. 0

\section{1-AN-107 Simulant}

$309^{\circ} \mathrm{C}$

DATE: $2 / 10 / 10$ TIME: $9.40 \mathrm{Am}$ TEMP: $\frac{30.7^{\circ} \mathrm{C}}{29.0^{\circ} \mathrm{C}} \mathrm{pH}: 10.17$

ASTM A537 Electrode vs. Immersed MPCMS Reference Electrodes

\begin{tabular}{|l|c|c|c|}
\hline & $\begin{array}{c}\text { MPCMS } \\
\text { Ag/AgCl }\end{array}$ & $\begin{array}{c}\text { MPCMS } \\
\text { Calomel }\end{array}$ & $\begin{array}{c}\text { MPCMIS } \\
\text { Cu/CuSO }\end{array}$ \\
\hline ASTM A537 & -287.1 & -331.4 & -41.2 \\
\hline
\end{tabular}

Test Electrodes vs. Room Temperature MPCMS Reference Electrodes

\begin{tabular}{|l|c|c|c|}
\hline & $\begin{array}{c}\text { MPCMS } \\
\text { Ag/AgCl }\end{array}$ & $\begin{array}{c}\text { MPCMS } \\
\text { Calomel }\end{array}$ & $\begin{array}{c}\text { MPCMS } \\
\text { Cu/CuSO }\end{array}$ \\
\hline ASTM A537 & -289.0 & -3.30 .2 & -402.1 \\
\hline $\begin{array}{l}\text { MPCMS } \\
\text { Ag/AgCl }\end{array}$ & -6.9 & & \\
\hline $\begin{array}{l}\text { MPCMS } \\
\text { Calomel }\end{array}$ & & -2.0 & \\
\hline $\begin{array}{l}\text { MPCMS } \\
\text { Cu/CuSO }\end{array}$ & & & +6 \\
\hline
\end{tabular}

Test Electrodes vs. Room Temperature Laboratory-Grade Reference Electrodes

\begin{tabular}{|l|c|c|c|}
\hline & $\begin{array}{c}\text { Laboratory } \\
\text { Ag/AgCI }\end{array}$ & $\begin{array}{c}\text { Laboratory } \\
\text { Calomel }\end{array}$ & $\begin{array}{c}\text { Laboratory } \\
\text { Cu/CuSO }\end{array}$ \\
\hline ASTM A537 & -300.5 & -326.1 & -385.2 \\
\hline $\begin{array}{l}\text { MPCMS } \\
\text { Ag/AgCI }\end{array}$ & -21.1 & & \\
\hline $\begin{array}{l}\text { MPCMS } \\
\text { Calomel }\end{array}$ & & -0.7 & \\
\hline $\begin{array}{l}\text { MPCMS } \\
\text { Cu/CuSO }\end{array}$ & & & -72.7 \\
\hline
\end{tabular}

This page may be reproduced as necessary

C-3

Page

of 
RPP-RPT-44463, Rev. 0

RPP-PLAN-43915, Rev. 0

\section{1-AY-101 Simulant}

28.87

DATE: $2 / 10 / 10$ тIME: 1.30 pm TEMP: 28.78 pH: 10.97

$27.0^{\circ} \mathrm{C}$

AAR TC128 Electrode vs. Immersed MPCMS Reference Electrodes

\begin{tabular}{|l|c|c|c|}
\hline & $\begin{array}{c}\text { MPCMS } \\
\text { Ag/AgCl }\end{array}$ & $\begin{array}{c}\text { MPCMS } \\
\text { Calomel }\end{array}$ & $\begin{array}{c}\text { MPCMS } \\
\text { Cu/CuSO }\end{array}$ \\
\hline AAR TC128 & -2638 & -308.3 & -364.7 \\
\hline
\end{tabular}

Test Electrodes vs. Room Temperature MPCMS Reference Electrodes

\begin{tabular}{|l|c|c|c|}
\hline & $\begin{array}{c}\text { MPCMS } \\
\text { Ag/AgCI }\end{array}$ & $\begin{array}{c}\text { MPCMS } \\
\text { Calomel }\end{array}$ & $\begin{array}{c}\text { MPCMS } \\
\text { Cu/CuSO }\end{array}$ \\
\hline AAR TC128 & $-25 i 8$ & -29.8 & -366.9 \\
\hline $\begin{array}{l}\text { MPCMS } \\
\text { Ag/AgCI }\end{array}$ & 11.1 & & \\
\hline $\begin{array}{l}\text { MPCMS } \\
\text { Calomel }\end{array}$ & & 13.5 & -3.6 \\
\hline $\begin{array}{l}\text { MPCMS } \\
\text { Cu/CuSO }\end{array}$ & & & \\
\hline
\end{tabular}

Test Electrodes vs. Room Temperature Laboratory-Grade Reference Electrodes

\begin{tabular}{|l|c|c|c|}
\hline & $\begin{array}{c}\text { Laboratory } \\
\text { Ag/AgCl }\end{array}$ & $\begin{array}{c}\text { Laboratory } \\
\text { Calomel }\end{array}$ & $\begin{array}{c}\text { Laboratory } \\
\text { Cu/CuSO4 }\end{array}$ \\
\hline AAR TC128 & -265.1 & -291.8 & -3525 \\
\hline MPCMS Ag/AgCl & -2.7 & & \\
\hline MPCMS Calomel & & 14.8 & 10.7 \\
\hline $\begin{array}{l}\text { MPCMS } \\
\text { Cu/CuSO }\end{array}$ & & & \\
\hline
\end{tabular}

This page may be reproduced as necessary. of 
RPP-RPT-44463, Rev. 0

RPP-PLAN-43915, Rev. 0

241-AN-107 Simulant

28.87

DATE: $\underline{2 / 10 / 10}$ TIME: $1: 35 \mathrm{pm}$ TEMP: $\frac{28.79^{\circ} \mathrm{C}}{27.0^{\circ} \mathrm{C}}$ pH: 9.99

ASTM A537 Electrode vs. Immersed MPCMS Reference Electrodles

\begin{tabular}{|l|c|c|c|}
\hline & $\begin{array}{c}\text { MPCMS } \\
\text { Ag/AgCl }\end{array}$ & $\begin{array}{c}\text { MPCMS } \\
\text { Calomel }\end{array}$ & $\begin{array}{c}\text { MPCMIS } \\
\text { Cu/CuSO }\end{array}$ \\
\hline ASTM A537 & -291.6 & -336.3 & -415.5 \\
\hline
\end{tabular}

Test Electrodes vs. Room Temperature MPCMS Reference Electrodes

\begin{tabular}{|l|c|c|c|}
\hline & $\begin{array}{c}\text { MPCMS } \\
\text { Ag/AgCl }\end{array}$ & $\begin{array}{c}\text { MPCMS } \\
\text { Calomel }\end{array}$ & $\begin{array}{c}\text { MPCMS } \\
\text { Cu/CuSO }\end{array}$ \\
\hline ASTM A537 & -294.4 & -335.7 & -40.8 .0 \\
\hline $\begin{array}{l}\text { MPCMS } \\
\text { Ag/AgCl }\end{array}$ & -6.9 & & \\
\hline $\begin{array}{l}\text { MPCMS } \\
\text { Calomel }\end{array}$ & & -28 & \\
\hline $\begin{array}{l}\text { MPCMS } \\
\text { Cu/CuSO }\end{array}$ & & & 6.5 \\
\hline
\end{tabular}

Test Electrodes vs. Room Temperature Laboratory-Grade Reference Electrodes

\begin{tabular}{|l|c|c|c|}
\hline & $\begin{array}{c}\text { Laboratory } \\
\mathbf{A g} / \mathbf{A g C l}\end{array}$ & $\begin{array}{c}\text { Laboratory } \\
\text { Calomel }\end{array}$ & $\begin{array}{c}\text { Laboratory } \\
\text { Cu/CuSO }\end{array}$ \\
\hline ASTM A537 & -305.1 & -331.3 & -391.5 \\
\hline $\begin{array}{l}\text { MPCMS } \\
\text { Ag/AgCI }\end{array}$ & -20.6 & & \\
\hline $\begin{array}{l}\text { MPCMS } \\
\text { Calomel }\end{array}$ & & -1.4 & \\
\hline $\begin{array}{l}\text { MPCMS } \\
\text { Cu/CuSO }\end{array}$ & & & 20.7 \\
\hline
\end{tabular}

This page may be reproduced as necessary

C-3

Page

of 
RPP-RPT-44463, Rev. 0

RPP-PLAN-43915, Rev. 0

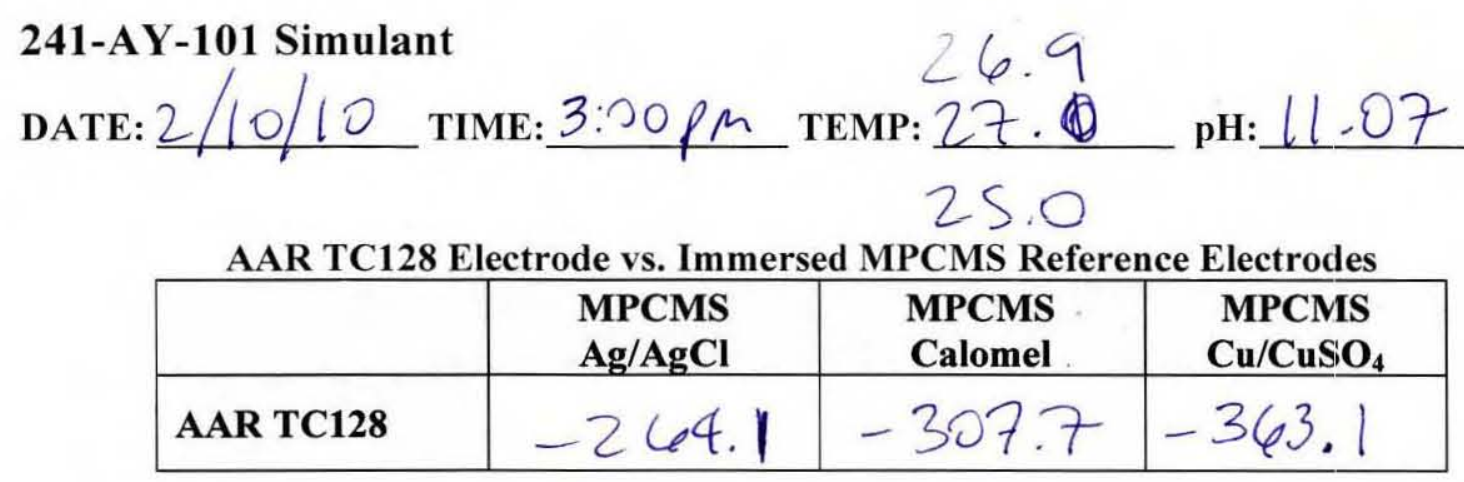

Test Electrodes vs. Room Temperature MPCMS Reference Electrodes

\begin{tabular}{|l|c|c|c|}
\hline & $\begin{array}{c}\text { MPCMS } \\
\text { Ag/AgCl }\end{array}$ & $\begin{array}{c}\text { MPCMS } \\
\text { Calomel }\end{array}$ & $\begin{array}{c}\text { MPCMS } \\
\text { Cu/CuSO }\end{array}$ \\
\hline AAR TC128 & -252.0 & -294.0 & -367.2 \\
\hline $\begin{array}{l}\text { MPCMS } \\
\text { Ag/AgCl }\end{array}$ & 11.2 & & \\
\hline $\begin{array}{l}\text { MPCMS } \\
\text { Calomel }\end{array}$ & & 12.8 & \\
\hline $\begin{array}{l}\text { MPCMS } \\
\text { Cu/CuSO }\end{array}$ & & & -5.1 \\
\hline
\end{tabular}

Test Electrodes vs. Room Temperature Laboratory-Grade Reference Electrodes

\begin{tabular}{|l|c|c|c|}
\hline & $\begin{array}{c}\text { Laboratory } \\
\text { Ag/AgCl }\end{array}$ & $\begin{array}{c}\text { Laboratory } \\
\text { Calomel }\end{array}$ & $\begin{array}{c}\text { Laboratory } \\
\text { Cu/CuSO }\end{array}$ \\
\hline AAR TC128 & -8.65 .3 & -292.1 & -353.2 \\
\hline MPCMS Ag/AgCl & -2.4 & & \\
\hline MPCMS Calomel & & 14.2 & 8.8 \\
\hline $\begin{array}{l}\text { MPCMS } \\
\text { Cu/CuSO }_{4}\end{array}$ & & & 8 \\
\hline
\end{tabular}

This page may be reproduced as necessary. of 
RPP-RPT-44463, Rev. 0

RPP-PLAN-43915, Rev. 0

241-AN-107 Simulant

$26.9^{\circ} \mathrm{C}$

DATE: $2 / 10 / 10$

TIME: $3: 05$ p

TEMP: $27.0^{\circ} \mathrm{C}$ pH: 9.98

25. $0^{\circ} \mathrm{C}$

ASTM A537 Electrode vs. Immersed MPCMS Reference Electrodes

\begin{tabular}{|l|c|c|c|}
\hline & $\begin{array}{c}\text { MPCMS } \\
\text { Ag/AgCl }\end{array}$ & $\begin{array}{c}\text { MPCMS } \\
\text { Calomel }\end{array}$ & $\begin{array}{c}\text { MPCMS } \\
\text { Cu/CuSO }\end{array}$ \\
\hline ASTM A537 & -2878 & -332.2 & -4110 \\
\hline
\end{tabular}

Test Electrodes vs. Room Temperature MPCMS Reference Electrodes

\begin{tabular}{|l|c|c|c|}
\hline & $\begin{array}{c}\text { MPCMS } \\
\text { Ag/AgCl }\end{array}$ & $\begin{array}{c}\text { MPCMS } \\
\text { Calomel }\end{array}$ & $\begin{array}{c}\text { MPCMIS } \\
\text { Cu/CuSO }\end{array}$ \\
\hline ASTM A537 & -291.0 & -332.4 & -404.8 \\
\hline $\begin{array}{l}\text { MPCMS } \\
\text { Ag/AgCl }\end{array}$ & -6.9 & & \\
\hline $\begin{array}{l}\text { MPCMS } \\
\text { Calomel }\end{array}$ & & -3.4 & 5.7 \\
\hline $\begin{array}{l}\text { MPCMS } \\
\text { Cu/CuSO }\end{array}$ & & & \\
\hline
\end{tabular}

Test Electrodes vs. Room Temperature Laboratory-Grade Reference Electrodes

\begin{tabular}{|l|c|c|c|}
\hline & $\begin{array}{c}\text { Laboratory } \\
\text { Ag/AgCl }\end{array}$ & $\begin{array}{c}\text { Laboratory } \\
\text { Calomel }\end{array}$ & $\begin{array}{c}\text { Laboratory } \\
\text { Cu/CuSO }\end{array}$ \\
\hline ASTM A537 & -302.1 & -328.4 & -388.8 \\
\hline $\begin{array}{l}\text { MPCMS } \\
\text { Ag/AgCl }\end{array}$ & -20.5 & & \\
\hline $\begin{array}{l}\text { MPCMS } \\
\text { Calomel }\end{array}$ & & -2.0 & \\
\hline $\begin{array}{l}\text { MPCMS } \\
\text { Cu/CuSO }\end{array}$ & & & 19.5 \\
\hline
\end{tabular}

This page may be reproduced as necessary

C-3

Page

of 
RPP-RPT-44463, Rev. 0

RPP-PLAN-43915, Rev. 0

241-AY-101 Simulant

28.98

DATE: $2 / 11 / 10$ TIME: $9: 10$ AM TEMP: $\frac{28.78}{27.0^{\circ} \mathrm{C}} \mathrm{pH}: 11.04$

AAR TC128 Electrode vs. Immersed MPCMS Reference Electrodes

\begin{tabular}{|l|c|c|c|}
\hline & $\begin{array}{c}\text { MPCMS } \\
\mathbf{A g} / \mathbf{A g C l}\end{array}$ & $\begin{array}{c}\text { MPCMS } \\
\text { Calomel }\end{array}$ & $\begin{array}{c}\text { MPCMS } \\
\text { Cu/CuSO }_{4}\end{array}$ \\
\hline AAR TC128 & -258.6 & -303.5 & -361.2 \\
\hline
\end{tabular}

Test Electrodes vs. Room Temperature MPCMS Reference Electrodes

\begin{tabular}{|l|c|c|c|}
\hline & $\begin{array}{c}\text { MPCMS } \\
\mathbf{A g} / \text { AgCl }\end{array}$ & $\begin{array}{c}\text { MPCMS } \\
\text { Calomel }\end{array}$ & $\begin{array}{c}\text { MPCMS } \\
\text { Cu/CuSO }\end{array}$ \\
\hline AAR TC128 & -247.0 & -288.8 & -361.9 \\
\hline $\begin{array}{l}\text { MPCMS } \\
\text { Ag/AgCl }\end{array}$ & 10.5 & & \\
\hline $\begin{array}{l}\text { MPCMS } \\
\text { Calomel }\end{array}$ & & 13.5 & \\
\hline $\begin{array}{l}\text { MPCMS } \\
\text { Cu/CuSO }\end{array}$ & & & -2.2 \\
\hline
\end{tabular}

Test Electrodes vs. Room Temperature Laboratory-Grade Reference Electrodes

\begin{tabular}{|l|c|c|c|}
\hline & $\begin{array}{c}\text { Laboratory } \\
\text { Ag/AgCl }\end{array}$ & $\begin{array}{c}\text { Laboratory } \\
\text { Calomel }\end{array}$ & $\begin{array}{c}\text { Laboratory } \\
\text { Cu/CuSO }\end{array}$ \\
\hline AAR TC128 & -260.9 & -286.9 & -348.2 \\
\hline MPCMS Ag/AgCl & -3.8 & & \\
\hline MPCMS Calomel & & 14.9 & \\
\hline $\begin{array}{l}\text { MPCMS } \\
\text { Cu/CuSO }_{4}\end{array}$ & & & 11.4 \\
\hline
\end{tabular}

This page may be reproduced as necessary.

of 
RPP-RPT-44463, Rev. 0

RPP-PLAN-43915, Rev. 0

241-AN-107 Simulant

28.98

DATE: $2 / 11 / 10$ TIME: $9: 1 \mathrm{sam}$ TEMP: $\frac{28.78}{270^{\circ} \mathrm{C}}$ pH: 9.94

ASTM A537 Electrode vs. Immersed MPCMS Reference Electrodes

\begin{tabular}{|l|c|c|c|}
\hline & $\begin{array}{c}\text { MPCMS } \\
\mathbf{A g} / \mathbf{A g C l}\end{array}$ & $\begin{array}{c}\text { MPCMS } \\
\text { Calomel }\end{array}$ & $\begin{array}{c}\text { MPCMS } \\
\text { Cu/CuSO }_{4}\end{array}$ \\
\hline ASTM A537 & -274.0 & -319.4 & -398.9 \\
\hline
\end{tabular}

Test Electrodes vs. Room Temperature MPCMS Reference Electrodes

\begin{tabular}{|l|c|c|c|}
\hline & $\begin{array}{c}\text { MPCMS } \\
\text { Ag/AgCl }\end{array}$ & $\begin{array}{c}\text { MPCMS } \\
\text { Calomel }\end{array}$ & $\begin{array}{c}\text { MPCMS } \\
\text { Cu/CuSO }\end{array}$ \\
\hline ASTM A537 & -277.2 & -319.3 & -391.6 \\
\hline $\begin{array}{l}\text { MPCMS } \\
\text { Ag/AgCl }\end{array}$ & -6.9 & & \\
\hline $\begin{array}{l}\text { MPCMS } \\
\text { Calomel }\end{array}$ & & -2.7 & \\
\hline $\begin{array}{l}\text { MPCMS } \\
\text { Cu/CuSO }\end{array}$ & & & 6.6 \\
\hline
\end{tabular}

Test Electrodes vs. Room Temperature Laboratory-Grade Reference Electrodes

\begin{tabular}{|l|c|c|c|}
\hline & $\begin{array}{c}\text { Laboratory } \\
\text { Ag/AgCl }\end{array}$ & $\begin{array}{c}\text { Laboratory } \\
\text { Calomel }\end{array}$ & $\begin{array}{c}\text { Laboratory } \\
\text { Cu/CuSO }\end{array}$ \\
\hline ASTM A537 & -290.2 & -315.9 & -376.6 \\
\hline $\begin{array}{l}\text { MPCMS } \\
\text { Ag/AgCl }\end{array}$ & -21.3 & & \\
\hline $\begin{array}{l}\text { MPCMS } \\
\text { Calomel }\end{array}$ & & -1.3 & \\
\hline $\begin{array}{l}\text { MPCMS } \\
\text { Cu/CuSO }\end{array}$ & & & 20.0 \\
\hline
\end{tabular}

This page may be reproduced as necessary

of 
RPP-RPT-44463, Rev. 0

RPP-PLAN-43915, Rev. 0

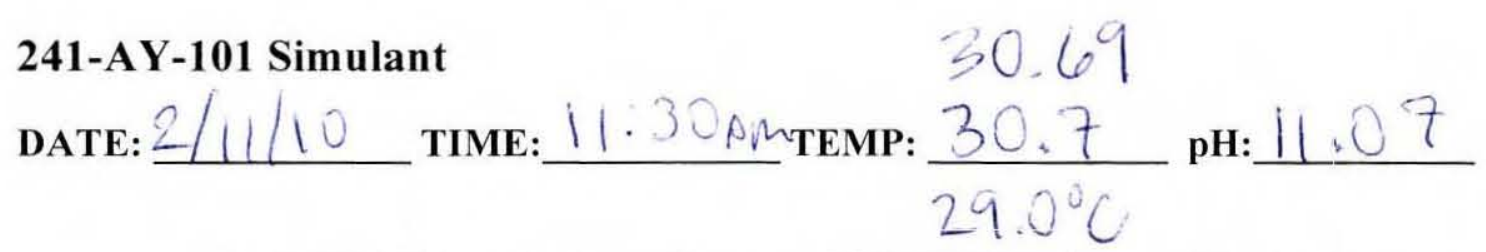

AAR TC128 Electrode vs. Immersed MPCMS Reference Electrodes

\begin{tabular}{|l|c|c|c|}
\hline & $\begin{array}{c}\text { MPCMS } \\
\text { Ag/AgCl }\end{array}$ & $\begin{array}{c}\text { MPCMS } \\
\text { Calomel }\end{array}$ & $\begin{array}{c}\text { MPCMIS } \\
\text { Cu/CuSO }\end{array}$ \\
\hline AAR TC128 & -259.0 & -304.8 & -362.5 \\
\hline
\end{tabular}

Test Electrodes vs. Room Temperature MPCMS Reference Electrodes

\begin{tabular}{|l|c|c|c|}
\hline & $\begin{array}{c}\text { MPCMS } \\
\text { Ag/AgCl }\end{array}$ & $\begin{array}{c}\text { MPCMS } \\
\text { Calomel }\end{array}$ & $\begin{array}{c}\text { MPCMS } \\
\text { Cu/CuSO }\end{array}$ \\
\hline AAR TC128 & -247.5 & -289.4 & -362.6 \\
\hline $\begin{array}{l}\text { MPCMS } \\
\text { Ag/AgCl }\end{array}$ & 10.5 & & \\
\hline $\begin{array}{l}\text { MPCMS } \\
\text { Calomel }\end{array}$ & & 14.3 & \\
\hline $\begin{array}{l}\text { MPCMS } \\
\text { Cu/CuSO }\end{array}$ & & & -1.5 \\
\hline
\end{tabular}

Test Electrodes vs. Room Temperature Laboratory-Grade Reference Electrodes

\begin{tabular}{|l|c|c|c|}
\hline & $\begin{array}{c}\text { Laboratory } \\
\text { Ag/AgCl }\end{array}$ & $\begin{array}{c}\text { Laboratory } \\
\text { Calomel }\end{array}$ & $\begin{array}{c}\text { Laboratory } \\
\text { Cu/CuSO4 }\end{array}$ \\
\hline AAR TC128 & -261.2 & -287.5 & -349.7 \\
\hline MPCMS Ag/AgCl & -3.5 & & \\
\hline MPCMS Calomel & & 15.6 & 11.4 \\
\hline $\begin{array}{l}\text { MPCMS } \\
\text { Cu/CuSO }\end{array}$ & & & 1.4 \\
\hline
\end{tabular}

This page may be reproduced as necessary.

of 
RPP-RPT-44463, Rev. 0

RPP-PLAN-43915, Rev. 0

241-AN-107 Simulant

30.7

DATE: $2 / 11 / 10$ TIME: $11: 40$ AM TEMP: $\frac{30.7}{29.0^{\circ} \mathrm{C}}$ pH: 10.01

ASTM A537 Electrode vs. Immersed MPCMS Reference Electrodes

\begin{tabular}{|l|c|c|c|}
\hline & $\begin{array}{c}\text { MPCMS } \\
\text { Ag/AgCl }\end{array}$ & $\begin{array}{c}\text { MPCMS } \\
\text { Calomel }\end{array}$ & $\begin{array}{c}\text { MPCMS } \\
\text { Cu/CuSO }\end{array}$ \\
\hline ASTM A537 & -267.5 & -313.7 & -393.4 \\
\hline
\end{tabular}

Test Electrodes vs. Room Temperature MPCMS Reference Electrodes

\begin{tabular}{|l|c|c|c|}
\hline & $\begin{array}{c}\text { MPCMS } \\
\text { Ag/AgCl }\end{array}$ & $\begin{array}{c}\text { MPCMS } \\
\text { Calomel }\end{array}$ & $\begin{array}{c}\text { MPCMS } \\
\text { Cu/CuSO }\end{array}$ \\
\hline ASTM A537 & -271.5 & -3129 & -385.7 \\
\hline $\begin{array}{l}\text { MPCMS } \\
\text { Ag/AgCl }\end{array}$ & -7.1 & & \\
\hline $\begin{array}{l}\text { MPCMS } \\
\text { Calomel }\end{array}$ & & -1.9 & \\
\hline $\begin{array}{l}\text { MPCMS } \\
\text { Cu/CuSO }_{4}\end{array}$ & & & 7.8 \\
\hline
\end{tabular}

Test Electrodes vs. Room Temperature Laboratory-Grade Reference Electrodes

\begin{tabular}{|l|c|c|c|}
\hline & $\begin{array}{c}\text { Laboratory } \\
\text { Ag/AgCl }\end{array}$ & $\begin{array}{c}\text { Laboratory } \\
\text { Calomel }\end{array}$ & $\begin{array}{c}\text { Laboratory } \\
\text { Cu/CuSO }\end{array}$ \\
\hline ASTM A537 & -283.4 & -309.2 & -371.1 \\
\hline $\begin{array}{l}\text { MPCMS } \\
\text { Ag/AgCl }\end{array}$ & -20.9 & & \\
\hline $\begin{array}{l}\text { MPCMS } \\
\text { Calomel }\end{array}$ & & -0.5 & \\
\hline $\begin{array}{l}\text { MPCMS } \\
\text { Cu/CuSO }\end{array}$ & & & 20.6 \\
\hline
\end{tabular}

This page may be reproduced as necessary

C-3

Page

of 
RPP-RPT-44463, Rev. 0

RPP-PLAN-43915, Rev. 0

\section{1-AY-101 Simulant}

$32.9^{\circ} \mathrm{C}$

DATE: $2 / 11 / 10$ TIME: $2: 00 \mathrm{pm}$ TеMP: $\frac{32 \cdot 6^{\circ} \mathrm{C}}{3 ! \cdot 0^{\circ} \mathrm{CH}: 11.09}$

AAR TC128 Electrode vs. Immersed MPCMS Reference Electrodles

\begin{tabular}{|l|c|c|c|}
\hline & $\begin{array}{c}\text { MPCMS } \\
\text { Ag/AgCI }\end{array}$ & $\begin{array}{c}\text { MPCMS } \\
\text { Calomel }\end{array}$ & $\begin{array}{c}\text { MPCMIS } \\
\text { Cu/CuSO }\end{array}$ \\
\hline AAR TC128 & -260.0 & -306.5 & -365.4 \\
\hline
\end{tabular}

Test Electrodes vs. Room Temperature MPCMS Reference Electrodes

\begin{tabular}{|l|c|c|c|}
\hline & $\begin{array}{c}\text { MPCMS } \\
\text { Ag/AgCl }\end{array}$ & $\begin{array}{c}\text { MPCMS } \\
\text { Calomel }\end{array}$ & $\begin{array}{c}\text { MPCMS } \\
\text { Cu/CuSO }\end{array}$ \\
\hline AAR TC128 & -248.4 & -290.4 & -363.6 \\
\hline $\begin{array}{l}\text { MPCMS } \\
\text { Ag/AgCl }\end{array}$ & 11.0 & & \\
\hline $\begin{array}{l}\text { MPCMS } \\
\text { Calomel }\end{array}$ & & 15.0 & \\
\hline $\begin{array}{l}\text { MPCMS } \\
\text { Cu/CuSO }\end{array}$ & & & 0.2 \\
\hline
\end{tabular}

Test Electrodes vs. Room Temperature Laboratory-Grade Reference Electrodes

\begin{tabular}{|l|c|c|c|}
\hline & $\begin{array}{c}\text { Laboratory } \\
\text { Ag/AgCl }\end{array}$ & $\begin{array}{c}\text { Laboratory } \\
\text { Calomel }\end{array}$ & $\begin{array}{c}\text { Laboratory } \\
\text { Cu/CuSO }\end{array}$ \\
\hline AAR TC128 & -2618 & -288.5 & -351.4 \\
\hline MPCMS Ag/AgCl & -2.9 & 16.4 & \\
\hline MPCMS Calomel & & & 12.4 \\
\hline $\begin{array}{l}\text { MPCMS } \\
\text { Cu/CuSO }_{4}\end{array}$ & & & \\
\hline
\end{tabular}

This page may be reproduced as necessary.

C-2

Page

of 
RPP-RPT-44463, Rev. 0

RPP-PLAN-43915, Rev. 0

\section{1-AN-107 Simulant}

$329^{\circ} \mathrm{C}$

DATE: $\underline{2 / 11 / 10}$ TIME: $205 \mathrm{fm}$ TEMP: $\frac{32.6^{\circ}}{310^{\circ} \mathrm{C}}$ pH: 10.07

ASTM A537 Electrode vs. Immersed MPCMS Reference Electrodes

\begin{tabular}{|l|c|c|c|}
\hline & $\begin{array}{c}\text { MPCMS } \\
\text { Ag/AgCI }\end{array}$ & $\begin{array}{c}\text { MPCMS } \\
\text { Calomel }\end{array}$ & $\begin{array}{c}\text { MPCMS } \\
\text { Cu/CuSO }\end{array}$ \\
\hline ASTM A537 & -260.7 & -307.9 & -388.4 \\
\hline
\end{tabular}

Test Electrodes vs. Room Temperature MPCMS Reference Electrodes

\begin{tabular}{|l|c|c|c|}
\hline & $\begin{array}{c}\text { MPCMS } \\
\text { Ag/AgCl }\end{array}$ & $\begin{array}{c}\text { MPCMS } \\
\text { Calomel }\end{array}$ & $\begin{array}{c}\text { MPCMS } \\
\text { Cu/CuSO }\end{array}$ \\
\hline ASTM A537 & -264.9 & -306.4 & -379.3 \\
\hline $\begin{array}{l}\text { MPCMS } \\
\text { Ag/AgCl }\end{array}$ & -7.1 & & \\
\hline $\begin{array}{l}\text { MPCMS } \\
\text { Calomel }\end{array}$ & & -1.2 & 89 \\
\hline $\begin{array}{l}\text { MPCMS } \\
\text { Cu/CuSO }\end{array}$ & & & 89 \\
\hline
\end{tabular}

Test Electrodes vs. Room Temperature Laboratory-Grade Reference Electrodes

\begin{tabular}{|l|c|c|c|}
\hline & $\begin{array}{c}\text { Laboratory } \\
\text { Ag/AgCl }\end{array}$ & $\begin{array}{c}\text { Laboratory } \\
\text { Calomel }\end{array}$ & $\begin{array}{c}\text { Laboratory } \\
\text { Cu/CuSO }\end{array}$ \\
\hline ASTM A537 & -277.0 & -303.1 & -365.8 \\
\hline $\begin{array}{l}\text { MPCMS } \\
\text { Ag/AgCl }\end{array}$ & -20.9 & & \\
\hline $\begin{array}{l}\text { MPCMS } \\
\text { Calomel }\end{array}$ & & 0.2 & 20.9 \\
\hline $\begin{array}{l}\text { MPCMS } \\
\text { Cu/CuSO }\end{array}$ & & & 0.9 \\
\hline
\end{tabular}

This page may be reproduced as necessary

C-3

Page

of 
RPP-RPT-44463, Rev. 0

RPP-PLAN-43915, Rev. 0

241-AY-101 Simulant

$34.8^{\circ} \mathrm{C}$

DATE: $22 / 11 / 10_{\text {TIME: }} 5: 35 \mathrm{pm}$ TEMP: $\frac{34.8^{\circ} \mathrm{C}}{33.0^{\circ} \mathrm{C}} \mathbf{\mathrm { C }} 11.08$

AAR TC128 Electrode vs. Immersed MPCMS Reference Electrodes

\begin{tabular}{|l|c|c|c|}
\hline & $\begin{array}{c}\text { MPCMS } \\
\mathbf{A g} / \mathbf{A g C l}\end{array}$ & $\begin{array}{c}\text { MPCMS } \\
\text { Calomel }\end{array}$ & $\begin{array}{c}\text { MPCMS } \\
\mathbf{C u}_{\mathbf{C u S O}}\end{array}$ \\
\hline AAR TC128 & -271 & -318.2 & -376.2 \\
\hline
\end{tabular}

Test Electrodes vs. Room Temperature MPCMS Reference Electrodes

\begin{tabular}{|l|c|c|c|}
\hline & $\begin{array}{c}\text { MPCMS } \\
\mathbf{A g} / \mathbf{A g C l}\end{array}$ & $\begin{array}{c}\text { MPCMS } \\
\text { Calomel }\end{array}$ & $\begin{array}{c}\text { MPCMS } \\
\mathbf{C u} / \mathbf{C u S O}_{4}\end{array}$ \\
\hline AAR TC128 & -259.3 & -301.4 & -374.8 \\
\hline $\begin{array}{l}\text { MPCMS } \\
\text { Ag/AgCl }\end{array}$ & 0.6 & & \\
\hline $\begin{array}{l}\text { MPCMS } \\
\text { Calomel }\end{array}$ & & 15.9 & \\
\hline $\begin{array}{l}\text { MPCMS } \\
\text { Cu/CuSO }\end{array}$ & & & 0.2 \\
\hline
\end{tabular}

Test Electrodes vs. Room Temperature Laboratory-Grade Reference Ellectrodes

\begin{tabular}{|l|c|c|c|}
\hline & $\begin{array}{c}\text { Laboratory } \\
\text { Ag/AgCl }\end{array}$ & $\begin{array}{c}\text { Laboratory } \\
\text { Calomel }\end{array}$ & $\begin{array}{c}\text { Laboratory } \\
\text { Cu/CuSO }\end{array}$ \\
\hline AAR TC128 & -272.4 & -299.6 & -363.7 \\
\hline MPCMS Ag/AgCl & -2.8 & & \\
\hline MPCMS Calomel & & 17.3 & \\
\hline $\begin{array}{l}\text { MPCMS } \\
\text { Cu/CuSO }\end{array}$ & & & 11.5 \\
\hline
\end{tabular}

This page may be reproduced as necessary.

C-2

Page

of 
RPP-RPT-44463, Rev. 0

RPP-PLAN-43915, Rev. 0

241-AN-107 Simulant

DATE: $2 / 1 / 10$ TIME: 5 to pm TEMP:

$34.8^{\circ} \mathrm{C}$

ASTM A537 Electrode vs. Immersed MPCMS Reference Electrodles

\begin{tabular}{|l|c|c|c|}
\hline & $\begin{array}{c}\text { MPCMS } \\
\text { Ag/AgCI }\end{array}$ & $\begin{array}{c}\text { MPCMS } \\
\text { Calomel }\end{array}$ & $\begin{array}{c}\text { MPCMS } \\
\text { Cu/CuSO }\end{array}$ \\
\hline ASTM A537 & -2.51 .8 & -299.7 & -381.2 \\
\hline
\end{tabular}

Test Electrodes vs. Room Temperature MPCMS Reference Electrodes

\begin{tabular}{|l|c|c|c|}
\hline & $\begin{array}{c}\text { MPCMS } \\
\text { Ag/AgCI }\end{array}$ & $\begin{array}{c}\text { MPCMS } \\
\text { Calomel }\end{array}$ & $\begin{array}{c}\text { MPCMIS } \\
\text { Cu/CuSO }\end{array}$ \\
\hline ASTM A537 & -255.9 & -297.4 & -370.1 \\
\hline $\begin{array}{l}\text { MPCMS } \\
\text { Ag/AgCI }\end{array}$ & -7.1 & & \\
\hline $\begin{array}{l}\text { MPCMS } \\
\text { Calomel }\end{array}$ & & -0.4 & \\
\hline $\begin{array}{l}\text { MPCMS } \\
\text { Cu/CuSO }\end{array}$ & & & 10.5 \\
\hline
\end{tabular}

Test Electrodes vs. Room Temperature Laboratory-Grade Reference Electrodes

\begin{tabular}{|l|c|c|c|}
\hline & $\begin{array}{c}\text { Laboratory } \\
\text { Ag/AgCl }\end{array}$ & $\begin{array}{c}\text { Laboratory } \\
\text { Calomel }\end{array}$ & $\begin{array}{c}\text { Laboratory } \\
\text { Cu/CuSO4 }\end{array}$ \\
\hline ASTM A537 & -267.2 & -293.9 & -3.57 .4 \\
\hline $\begin{array}{l}\text { MPCMS } \\
\text { Ag/AgCl }\end{array}$ & -20.4 & & \\
\hline $\begin{array}{l}\text { MPCMS } \\
\text { Calomel }\end{array}$ & & 0.9 & \\
\hline $\begin{array}{l}\text { MPCMS } \\
\text { Cu/CuSO }\end{array}$ & & & 21.7 \\
\hline
\end{tabular}

This page may be reproduced as necessary

of 
RPP-RPT-44463, Rev. 0

RPP-PLAN-43915, Rev. 0

\section{1-AY-101 Simulant \\ DATE: $2 / 12 / 10$ TIME: 925 AM TEMP: 36.8 pH: 10.99}

AAR TC128 Electrode vs. Immersed MPCMS Reference Electrodes

\begin{tabular}{|l|c|c|c|}
\hline & $\begin{array}{c}\text { MPCMS } \\
\text { Ag/AgCl }\end{array}$ & $\begin{array}{c}\text { MPCMS } \\
\text { Calomel }\end{array}$ & $\begin{array}{c}\text { MPCMIS } \\
\text { Cu/CuSO }\end{array}$ \\
\hline AAR TC128 & -275.8 & -324.1 & -379.6 \\
\hline
\end{tabular}

Test Electrodes vs. Room Temperature MPCMS Reference Electrodes

\begin{tabular}{|l|c|c|c|}
\hline & $\begin{array}{c}\text { MPCMS } \\
\text { Ag/AgCl }\end{array}$ & $\begin{array}{c}\text { MPCMS } \\
\text { Calomel }\end{array}$ & $\begin{array}{c}\text { MPCMIS } \\
\text { Cu/CuSO }\end{array}$ \\
\hline AAR TC128 & -264.4 & -3062 & -3796 \\
\hline $\begin{array}{l}\text { MPCMS } \\
\text { Ag/AgCl }\end{array}$ & 10.5 & & \\
\hline $\begin{array}{l}\text { MPCMS } \\
\text { Calomel }\end{array}$ & & 16.9 & \\
\hline $\begin{array}{l}\text { MPCMS } \\
\text { Cu/CuSO }\end{array}$ & & & -1.2 \\
\hline
\end{tabular}

Test Electrodes vs. Room Temperature Laboratory-Grade Reference Electrodes

\begin{tabular}{|l|c|c|c|}
\hline & $\begin{array}{c}\text { Laboratory } \\
\text { Ag/AgCl }\end{array}$ & $\begin{array}{c}\text { Laboratory } \\
\text { Calomel }\end{array}$ & $\begin{array}{c}\text { Laboratory } \\
\text { Cu/CuSO4 }\end{array}$ \\
\hline AAR TC128 & -279.3 & -304.8 & -368.1 \\
\hline MPCMS Ag/AgCl & -3.6 & & \\
\hline MPCMS Calomel & & 18.3 & 10.7 \\
\hline $\begin{array}{l}\text { MPCMS } \\
\text { Cu/CuSO }\end{array}$ & & & \\
\hline
\end{tabular}

This page may be reproduced as necessary.

C-2

Page

of 
RPP-RPT-44463, Rev. 0

RPP-PLAN-43915, Rev. 0

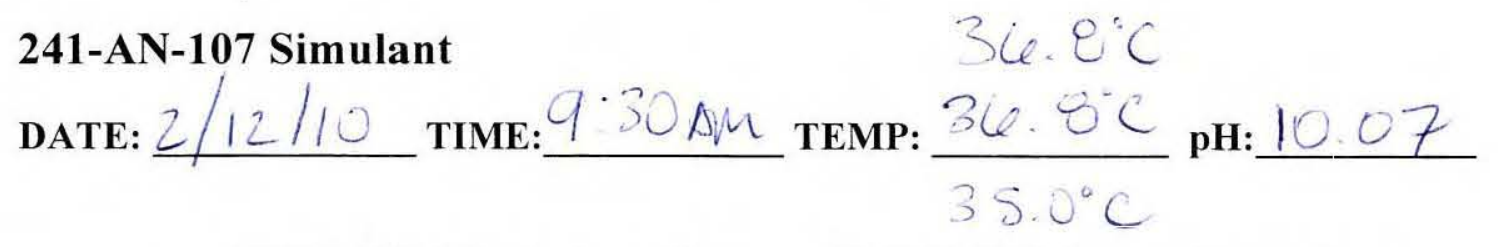

ASTM A537 Electrode vs. Immersed MPCMS Reference Electrodes

\begin{tabular}{|l|c|c|c|}
\hline & $\begin{array}{c}\text { MPCMS } \\
\text { Ag/AgCl }\end{array}$ & $\begin{array}{c}\text { MPCMS } \\
\text { Calomel }\end{array}$ & $\begin{array}{c}\text { MPCMS } \\
\text { Cu/CuSO }\end{array}$ \\
\hline ASTM A537 & -225.5 & -273.5 & -353.3 \\
\hline
\end{tabular}

Test Electrodes vs. Room Temperature MPCMS Reference Electrodes

\begin{tabular}{|l|c|c|c|}
\hline & $\begin{array}{c}\text { MPCMS } \\
\text { Ag/AgCl }\end{array}$ & $\begin{array}{c}\text { MPCMS } \\
\text { Calomel }\end{array}$ & $\begin{array}{c}\text { MPCMS } \\
\text { Cu/CuSO }\end{array}$ \\
\hline ASTM A537 & -284 & -269.7 & -342.4 \\
\hline $\begin{array}{l}\text { MPCMS } \\
\text { Ag/AgCl }\end{array}$ & -7.1 & & \\
\hline $\begin{array}{l}\text { MPCMS } \\
\text { Calomel }\end{array}$ & & -0.03 & \\
\hline $\begin{array}{l}\text { MPCMS } \\
\text { Cu/CuSO }\end{array}$ & & & 11.7 \\
\hline
\end{tabular}

Test Electrodes vs. Room Temperature Laboratory-Grade Reference Ellectrodes

\begin{tabular}{|l|c|c|c|}
\hline & $\begin{array}{c}\text { Laboratory } \\
\text { Ag/AgCl }\end{array}$ & $\begin{array}{c}\text { Laboratory } \\
\text { Calomel }\end{array}$ & $\begin{array}{c}\text { Laboratory } \\
\text { Cu/CuSO4 }\end{array}$ \\
\hline ASTM A537 & -24.5 & -267.8 & -348.1 \\
\hline $\begin{array}{l}\text { MPCMS } \\
\text { Ag/AgCl }\end{array}$ & -21.3 & & \\
\hline $\begin{array}{l}\text { MPCMS } \\
\text { Calomel }\end{array}$ & & 1.3 & \\
\hline $\begin{array}{l}\text { MPCMS } \\
\text { Cu/CuSO }\end{array}$ & & & 23.5 \\
\hline
\end{tabular}

This page may be reproduced as necessary

C-3

Page

of 
RPP-RPT-44463, Rev. 0

RPP-PLAN-43915, Rev. 0

241-AY-101 Simulant

DATE: $24(2,0$ TIME: $12,00 \mathrm{pm}$ TEMP:

$41.9^{\circ} \mathrm{C}$

$P: 4.6^{\circ} \mathrm{C}$ $\mathrm{pH}: 11.11$ $10.0^{\circ} \mathrm{C}$

AAR TC128 Electrode vs. Immersed MPCMS Reference Electrodes

\begin{tabular}{|l|c|c|c|}
\hline & $\begin{array}{c}\text { MPCMS } \\
\text { Ag/AgCI }\end{array}$ & $\begin{array}{c}\text { MPCMS } \\
\text { Calomel }\end{array}$ & $\begin{array}{c}\text { MPCMS } \\
\text { Cu/CuSO }\end{array}$ \\
\hline AAR TC128 & -270. & & \\
\hline
\end{tabular}

Test Electrodes vs. Room Temperature MPCMS Reference Electrodes

\begin{tabular}{|l|c|c|c|}
\hline & $\begin{array}{c}\text { MPCMS } \\
\text { Ag/AgCl }\end{array}$ & $\begin{array}{c}\text { MPCMS } \\
\text { Calomel }\end{array}$ & $\begin{array}{c}\text { MPCMIS } \\
\text { Cu/CuSO }\end{array}$ \\
\hline AAR TC128 & -260.1 & -302.2 & -375.7 \\
\hline $\begin{array}{l}\text { MPCMS } \\
\text { Ag/AgCl }\end{array}$ & 9.8 & & \\
\hline $\begin{array}{l}\text { MPCMS } \\
\text { Calomel }\end{array}$ & & 18.9 & \\
\hline $\begin{array}{l}\text { MPCMS } \\
\text { Cu/CuSO }\end{array}$ & & & 0.6 \\
\hline
\end{tabular}

Test Electrodes vs. Room Temperature Laboratory-Grade Reference Electrodes

\begin{tabular}{|l|c|c|c|}
\hline & $\begin{array}{c}\text { Laboratory } \\
\text { Ag/AgCl }\end{array}$ & $\begin{array}{c}\text { Laboratory } \\
\text { Calomel }\end{array}$ & $\begin{array}{c}\text { Laboratory } \\
\text { Cu/CuSO4 }\end{array}$ \\
\hline AAR TC128 & -2739 & -300.5 & -364.6 \\
\hline MPCMS Ag/AgCl & -4.1 & & \\
\hline MPCMS Calomel & & 20.2 & 11.7 \\
\hline $\begin{array}{l}\text { MPCMS } \\
\text { Cu/CuSO }\end{array}$ & & & \\
\hline
\end{tabular}

This page may be reproduced as necessary.

of 
RPP-RPT-44463, Rev. 0

RPP-PLAN-43915, Rev. 0

\section{1-AN-107 Simulant}

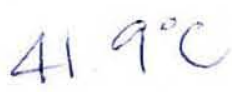

DATE: 211410 TIME: $1205 \mathrm{pm}$ TEMP: $\frac{41 \cdot 6^{\circ} \mathrm{C}}{40.0^{\circ} \mathrm{C}}$ pH: 10.21

ASTM A537 Electrode vs. Immersed MPCMS Reference Electrodes

\begin{tabular}{|l|c|c|c|}
\hline & $\begin{array}{c}\text { MPCMS } \\
\text { Ag/AgCl }\end{array}$ & $\begin{array}{c}\text { MPCMS } \\
\text { Calomel }\end{array}$ & $\begin{array}{c}\text { MPCMS } \\
\text { Cu/CuSO }\end{array}$ \\
\hline ASTM A537 & -221.1 & -2714 & -353.9 \\
\hline
\end{tabular}

Test Electrodes vs. Room Temperature MPCMS Reference Electrodes

\begin{tabular}{|l|c|c|c|}
\hline & $\begin{array}{c}\text { MPCMS } \\
\mathbf{A g} / \mathbf{A g C l}\end{array}$ & $\begin{array}{c}\text { MPCMS } \\
\text { Calomel }\end{array}$ & $\begin{array}{c}\text { MPCMS } \\
\mathbf{C u} / \text { CuSO }_{4}\end{array}$ \\
\hline ASTM A537 & -225.6 & -267.2 & -340.1 \\
\hline $\begin{array}{l}\text { MPCMS } \\
\text { Ag/AgCl }\end{array}$ & -7.5 & & \\
\hline $\begin{array}{l}\text { MPCMS } \\
\text { Calomel }\end{array}$ & & 1.5 & \\
\hline $\begin{array}{l}\text { MPCMS } \\
\text { Cu/CuSO }\end{array}$ & & & 14.7 \\
\hline
\end{tabular}

Test Electrodes vs. Room Temperature Laboratory-Grade Reference Ellectrodes

\begin{tabular}{|l|c|c|c|}
\hline & $\begin{array}{c}\text { Laboratory } \\
\mathbf{A g} / \mathbf{A g C l}\end{array}$ & $\begin{array}{c}\text { Laboratory } \\
\text { Calomel }\end{array}$ & $\begin{array}{c}\text { Laboratory } \\
\text { Cu/CuSO }\end{array}$ \\
\hline ASTM A537 & -2376 & -263.7 & -327.1 \\
\hline $\begin{array}{l}\text { MPCMS } \\
\text { Ag/AgCl }\end{array}$ & -214 & & \\
\hline $\begin{array}{l}\text { MPCMS } \\
\text { Calomel }\end{array}$ & & 29 & \\
\hline $\begin{array}{l}\text { MPCMS } \\
\text { Cu/CuSO }\end{array}$ & & & 07257 \\
\hline
\end{tabular}

This page may be reproduced as necessary

C-3

Page

of 
RPP-RPT-44463, Rev. 0

RPP-PLAN-43915, Rev. 0

241-AY-101 Simulant

DATE: $2 / 12 / 10$ TIME: $Z^{+2} \cdot 3$, K TEMP:

46.3

pH:

pH: 11.10

AAR TC128 Electrode vs. Immersed MPCMS Reference Electrodes

\begin{tabular}{|l|c|c|c|}
\hline & $\begin{array}{c}\text { MPCMS } \\
\text { Ag/AgCl }\end{array}$ & $\begin{array}{c}\text { MPCMS } \\
\text { Calomel }\end{array}$ & $\begin{array}{c}\text { MPCMIS } \\
\text { Cu/CuSO }\end{array}$ \\
\hline AAR TC128 & $-259+612.6$ & -36.2 \\
\hline
\end{tabular}

Test Electrodes vs. Room Temperature MPCMS Reference Electrodes

\begin{tabular}{|l|c|c|c|}
\hline & $\begin{array}{c}\text { MPCMS } \\
\text { Ag/AgCl }\end{array}$ & $\begin{array}{c}\text { MPCMS } \\
\text { Calomel }\end{array}$ & $\begin{array}{c}\text { MPCMIS } \\
\text { Cu/CuSO }\end{array}$ \\
\hline AAR TC128 & 240.9 & -290.9 & -364 \\
\hline $\begin{array}{l}\text { MPCMS } \\
\text { Ag/AgCl }\end{array}$ & 13 & & \\
\hline $\begin{array}{l}\text { MPCMS } \\
\text { Calomel }\end{array}$ & & +20.9 & \\
\hline $\begin{array}{l}\text { MPCMS } \\
\text { Cu/CuSO }\end{array}$ & & & 5 \\
\hline
\end{tabular}

Test Electrodes vs. Room Temperature Laboratory-Grade Reference Electrodes

\begin{tabular}{|l|c|c|c|}
\hline & $\begin{array}{c}\text { Laboratory } \\
\text { Ag/AgCl }\end{array}$ & $\begin{array}{c}\text { Laboratory } \\
\text { Calomel }\end{array}$ & $\begin{array}{c}\text { Laboratory } \\
\text { Cu/CuSO }\end{array}$ \\
\hline AAR TC128 & -262.2 & 289.2 & -3.5 .3 \\
\hline MPCMS Ag/AgCl & 42 & & \\
\hline MPCMS Calomel & & 22.2 & \\
\hline $\begin{array}{l}\text { MPCMS } \\
\text { Cu/CuSO }\end{array}$ & & & 12.6 \\
\hline
\end{tabular}

This page may be reproduced as necessary.

C-2

Page

of 
RPP-RPT-44463, Rev. 0

RPP-PLAN-43915, Rev. 0

\section{1-AN-107 Simulant}

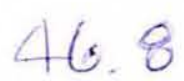

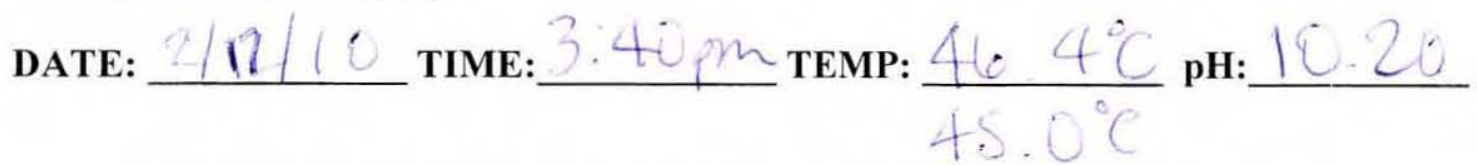

ASTM A537 Electrode vs. Immersed MPCMS Reference Electrodes

\begin{tabular}{|l|c|c|c|}
\hline & $\begin{array}{l}\text { MPCMS } \\
\text { Ag/AgCl }\end{array}$ & $\begin{array}{c}\text { MPCMS } \\
\text { Calomel }\end{array}$ & $\begin{array}{c}\text { MPCMS } \\
\text { Cu/CuSO }\end{array}$ \\
\hline ASTM A537 & 220,7 & $272 \%$ & -379 \\
\hline
\end{tabular}

Test Electrodes vs. Room Temperature MPCMS Reference Electrodes

\begin{tabular}{|c|c|c|c|}
\hline & $\begin{array}{l}\text { MPCMS } \\
\text { Ag/AgCl }\end{array}$ & $\begin{array}{l}\text { MPCMS } \\
\text { Calomel } \\
\end{array}$ & $\begin{array}{c}\mathrm{MPCMS} \\
\mathrm{Cu} / \mathrm{CuSO}_{4} \\
\end{array}$ \\
\hline ASTM A537 & -224.1 & $-2 \varphi) \varphi$ & -3.38 .1 \\
\hline $\begin{array}{l}\text { MPCMS } \\
\text { Ag/AgCl }\end{array}$ & & & \\
\hline $\begin{array}{l}\text { MPCMS } \\
\text { Calomel }\end{array}$ & & 3.1 & \\
\hline 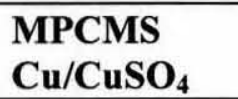 & & & 10.7 \\
\hline
\end{tabular}

Test Electrodes vs. Room Temperature Laboratory-Grade Reference Electrodes

\begin{tabular}{|c|c|c|c|}
\hline$x^{2+2}$ & $\begin{array}{c}\text { Laboratory } \\
\text { Ag/AgCl }\end{array}$ & $\begin{array}{c}\text { Laboratory } \\
\text { Calomel }\end{array}$ & $\begin{array}{l}\text { Laboratory } \\
\mathrm{Cu} / \mathrm{CuSO}_{4}\end{array}$ \\
\hline ASTM A537 & -2.36 .1 & -262.8 & -326.3 \\
\hline $\begin{array}{l}\text { MPCMS } \\
\mathrm{Ag} / \mathrm{AgCl}\end{array}$ & -21.2 & & . \\
\hline $\begin{array}{l}\text { MPCMS } \\
\text { Calomel }\end{array}$ & & 4,4 & \\
\hline $\begin{array}{l}\mathrm{MPCMS} \\
\mathrm{Cu} / \mathrm{CuSO}_{4}\end{array}$ & & & 20.8 \\
\hline
\end{tabular}

This page may be reproduced as necessary

C-3

Page

of 
RPP-RPT-44463, Rev. 0

RPP-PLAN-43915, Rev. 0

241-AY-101 Simulant

$51.9^{\circ} \mathrm{C}$

DATE:

TIME:

TEMP:

$\mathrm{pH}:$

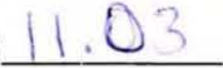

AAR TC128 Electrode vs. Immersed MPCMS Reference Electrodes

\begin{tabular}{|l|c|c|c|}
\hline & $\begin{array}{c}\text { MPCMS } \\
\text { Ag/AgCl }\end{array}$ & $\begin{array}{c}\text { MPCMS } \\
\text { Calomel }\end{array}$ & $\begin{array}{c}\text { MPCMIS } \\
\text { Cu/CuSO }\end{array}$ \\
\hline AAR TC128 & -204.4 & -2590 & -311.2 \\
\hline
\end{tabular}

Test Electrodes vs. Room Temperature MPCMS Reference Electrodes

\begin{tabular}{|l|c|c|c|}
\hline & $\begin{array}{c}\text { MPCMS } \\
\text { Ag/AgCl }\end{array}$ & $\begin{array}{c}\text { MPCMS } \\
\text { Calomel }\end{array}$ & $\begin{array}{c}\text { MPCMIS } \\
\text { Cu/CuSO }\end{array}$ \\
\hline AAR TC128 & -193.9 & -235.6 & -308.9 \\
\hline $\begin{array}{l}\text { MPCMS } \\
\text { Ag/AgCl }\end{array}$ & 9.6 & & \\
\hline $\begin{array}{l}\text { MPCMS } \\
\text { Calomel }\end{array}$ & & 22.8 & \\
\hline $\begin{array}{l}\text { MPCMS } \\
\text { Cu/CuSO }\end{array}$ & & & 1.2 \\
\hline
\end{tabular}

Test Electrodes vs. Room Temperature Laboratory-Grade Reference Electrodes

\begin{tabular}{|l|c|c|c|}
\hline & $\begin{array}{c}\text { Laboratory } \\
\text { Ag/AgCl }\end{array}$ & $\begin{array}{c}\text { Laboratory } \\
\text { Calomel }\end{array}$ & $\begin{array}{c}\text { Laboratory } \\
\text { Cu/CuSO }\end{array}$ \\
\hline AAR TC128 & -2079 & -2.3 .7 & -294.2 \\
\hline MPCMS Ag/AgCl & -4.7 & & \\
\hline MPCMS Calomel & & 24.1 & 10.9 \\
\hline $\begin{array}{l}\text { MPCMS } \\
\text { Cu/CuSO }\end{array}$ & & & 1 \\
\hline
\end{tabular}

This page may be reproduced as necessary.

of 


$$
\text { RPP-RPT-44463, Rev. } 0
$$

RPP-PLAN-43915, Rev. 0

\section{1-AN-107 Simulant}
DATE:
TIME:
TEMP:
pH: 10.25

ASTM A537 Electrode vs. Immersed MPCMS Reference Electrodes

\begin{tabular}{|l|c|c|c|}
\hline & $\begin{array}{c}\text { MPCMS } \\
\text { Ag/AgCl }\end{array}$ & $\begin{array}{c}\text { MPCMS } \\
\text { Calomel }\end{array}$ & $\begin{array}{c}\text { MPCMS } \\
\text { Cu/CuSO }\end{array}$ \\
\hline ASTM A537 & -277.3 & -2678 & -3523 \\
\hline
\end{tabular}

Test Electrodes vs. Room Temperature MPCMS Reference Electrodes

\begin{tabular}{|l|c|c|c|}
\hline & $\begin{array}{c}\text { MPCMS } \\
\text { Ag/AgCl }\end{array}$ & $\begin{array}{c}\text { MPCMS } \\
\text { Calomel }\end{array}$ & $\begin{array}{c}\text { MPCMS } \\
\text { Cu/CuSO }\end{array}$ \\
\hline ASTM A537 & -217.9 & 2.9 .1 & -330.1 \\
\hline $\begin{array}{l}\text { MPCMS } \\
\text { Ag/AgCl }\end{array}$ & -6.1 & & \\
\hline $\begin{array}{l}\text { MPCMS } \\
\text { Calomel }\end{array}$ & & 4.4 & \\
\hline $\begin{array}{l}\text { MPCMS } \\
\text { Cu/CuSO }\end{array}$ & & & 2.2 \\
\hline
\end{tabular}

Test Electrodes vs. Room Temperature Laboratory-Grade Reference Electrodes

\begin{tabular}{|l|c|c|c|}
\hline & $\begin{array}{c}\text { Laboratory } \\
\text { Ag/AgCl }\end{array}$ & $\begin{array}{c}\text { Laboratory } \\
\text { Calomel }\end{array}$ & $\begin{array}{c}\text { Laboratory } \\
\text { Cu/CuSO4 }\end{array}$ \\
\hline ASTM A537 & -247.2 & -2 & 217.9 \\
\hline $\begin{array}{l}\text { MPCMS } \\
\text { Ag/AgCl }\end{array}$ & -20.4 & & \\
\hline $\begin{array}{l}\text { MPCMS } \\
\text { Calomel }\end{array}$ & & 5.8 & \\
\hline $\begin{array}{l}\text { MPCMS } \\
\text { Cu/CuSO }\end{array}$ & & & 2.5 \\
\hline
\end{tabular}

This page may be reproduced as necessary

C-3

Page

of 
RPP-RPT-44463, Rev. 0

RPP-PLAN-43915, Rev. 0

241-AY-101 Simulant

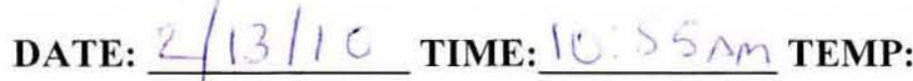
pH:

AAR TC128 Electrode vs. Immersed MPCMS Reference Electrodes

\begin{tabular}{|l|c|c|c|}
\hline & $\begin{array}{c}\text { MPCMS } \\
\text { Ag/AgCl }\end{array}$ & $\begin{array}{c}\text { MPCMS } \\
\text { Calomel }\end{array}$ & $\begin{array}{c}\text { MPCMIS } \\
\text { Cu/CuSO }\end{array}$ \\
\hline AAR TC128 & $\ldots 11.5$ & -2.4 .5 & -3.34 \\
\hline
\end{tabular}

Test Electrodes vs. Room Temperature MPCMS Reference Electrodes

\begin{tabular}{|l|c|c|c|}
\hline & $\begin{array}{c}\text { MPCMS } \\
\text { Ag/AgCl }\end{array}$ & $\begin{array}{c}\text { MPCMS } \\
\text { Calomel }\end{array}$ & $\begin{array}{c}\text { MPCMS } \\
\text { Cu/CuSO }\end{array}$ \\
\hline AAR TC128 & 202.3 & -244.7 & -317.6 \\
\hline $\begin{array}{l}\text { MPCMS } \\
\text { Ag/AgCl }\end{array}$ & 0.5 & & \\
\hline $\begin{array}{l}\text { MPCMS } \\
\text { Calomel }\end{array}$ & & 24.7 & \\
\hline $\begin{array}{l}\text { MPCMS } \\
\text { Cu/CuSO }\end{array}$ & & & 2.9 \\
\hline
\end{tabular}

Test Electrodes vs. Room Temperature Laboratory-Grade Reference Ellectrodes

\begin{tabular}{|c|c|c|c|}
\hline & $\begin{array}{c}\text { Laboratory } \\
\text { Ag/AgCl }\end{array}$ & $\begin{array}{c}\text { Laboratory } \\
\text { Calomel }\end{array}$ & $\begin{array}{l}\text { Laboratory } \\
\mathrm{Cu} / \mathrm{CuSO}_{4}\end{array}$ \\
\hline AAR TC128 & -216.1 & 2424 & -308.5 \\
\hline MPCMS Ag/AgCl & -5.5 & & \\
\hline MPCMS Calomel & & 26.1 & \\
\hline $\begin{array}{l}\text { MPCMS } \\
\mathrm{Cu} / \mathrm{CuSO}_{4}\end{array}$ & & & 12.0 \\
\hline
\end{tabular}

This page may be reproduced as necessary.

C-2

Page

of 
RPP-RPT-44463, Rev. 0

RPP-PLAN-43915, Rev. 0

241-AN-107 Simulant

DATE: $2 / 13 / 10$ TIME: 1 í̃Am TEMP: $\mathbf{p H}: 10.29$

ASTM A537 Electrode vs. Immersed MPCMS Reference Electrodles

\begin{tabular}{|l|c|c|c|}
\hline & $\begin{array}{c}\text { MPCMS } \\
\text { Ag/AgCl }\end{array}$ & $\begin{array}{c}\text { MPCMS } \\
\text { Calomel }\end{array}$ & $\begin{array}{c}\text { MPCMIS } \\
\text { Cu/CuSO }\end{array}$ \\
\hline ASTM A537 & -2218 & -2758 & -362.9 \\
\hline
\end{tabular}

Test Electrodes vs. Room Temperature MPCMS Reference Electrodes

\begin{tabular}{|l|c|c|c|}
\hline & $\begin{array}{c}\text { MPCMS } \\
\text { Ag/AgCI }\end{array}$ & $\begin{array}{c}\text { MPCMS } \\
\text { Calomel }\end{array}$ & $\begin{array}{c}\text { MPCMIS } \\
\text { Cu/CuSO }\end{array}$ \\
\hline ASTM A537 & -22.54 & -266.8 & -3.78 \\
\hline $\begin{array}{l}\text { MPCMS } \\
\text { Ag/AgCl }\end{array}$ & -27 & & \\
\hline $\begin{array}{l}\text { MPCMS } \\
\text { Calomel }\end{array}$ & & 6.1 & \\
\hline $\begin{array}{l}\text { MPCMS } \\
\text { Cu/CuSO }\end{array}$ & & & 24.4 \\
\hline
\end{tabular}

Test Electrodes vs. Room Temperature Laboratory-Grade Reference Electrodes

\begin{tabular}{|l|c|c|c|}
\hline & $\begin{array}{c}\text { Laboratory } \\
\text { Ag/AgCl }\end{array}$ & $\begin{array}{c}\text { Laboratory } \\
\text { Calomel }\end{array}$ & $\begin{array}{c}\text { Laboratory } \\
\text { Cu/CuSO }\end{array}$ \\
\hline ASTM A537 & -2.7 .9 & 26.3 & -329.5 \\
\hline $\begin{array}{l}\text { MPCMS } \\
\text { Ag/AgCl }\end{array}$ & -20.7 & & \\
\hline $\begin{array}{l}\text { MPCMS } \\
\text { Calomel }\end{array}$ & & 7.5 & \\
\hline $\begin{array}{l}\text { MPCMS } \\
\text { Cu/CuSO }\end{array}$ & & & 3.4 \\
\hline
\end{tabular}

This page may be reproduced as necessary

C-3

Page

of 
RPP-RPT-44463, Rev. 0

RPP-PLAN-43915, Rev. 0

241-AY-101 Simulant

DATE: $2 / 13 / 10$ TIME: $12^{\circ}$ S.J pm TEMP: $41.2^{\circ} \mathrm{C}$ pH: 10.63 (.C. C C

AAR TC128 Electrode vs. Immersed MPCMS Reference Electrodles

\begin{tabular}{|l|c|c|c|}
\hline & $\begin{array}{c}\text { MPCMS } \\
\text { Ag/AgCl }\end{array}$ & $\begin{array}{c}\text { MPCMS } \\
\text { Calomel }\end{array}$ & $\begin{array}{c}\text { MPCMS } \\
\text { Cu/CuSO }\end{array}$ \\
\hline AAR TC128 & -217.2 & -27.99 & -332.2 \\
\hline
\end{tabular}

Test Electrodes vs. Room Temperature MPCMS Reference Electrodes

\begin{tabular}{|l|c|c|c|}
\hline & $\begin{array}{c}\text { MPCMS } \\
\text { Ag/AgCl }\end{array}$ & $\begin{array}{c}\text { MPCMS } \\
\text { Calomel }\end{array}$ & $\begin{array}{c}\text { MPCMS } \\
\text { Cu/CuSO }\end{array}$ \\
\hline AAR TC128 & -208.9 & -250.7 & -324.3 \\
\hline $\begin{array}{l}\text { MPCMS } \\
\text { Ag/AgCl }\end{array}$ & $7 .(0$ & & \\
\hline $\begin{array}{l}\text { MPCMS } \\
\text { Calomel }\end{array}$ & & 26.6 & \\
\hline $\begin{array}{l}\text { MPCMS } \\
\text { Cu/CuSO }\end{array}$ & & & 6 \\
\hline
\end{tabular}

Test Electrodes vs. Room Temperature Laboratory-Grade Reference Electrodes

\begin{tabular}{|l|c|c|c|}
\hline & $\begin{array}{c}\text { Laboratory } \\
\text { Ag/AgCI }\end{array}$ & $\begin{array}{c}\text { Laboratory } \\
\text { Calomel }\end{array}$ & $\begin{array}{c}\text { Laboratory } \\
\text { Cu/CuSO }\end{array}$ \\
\hline AAR TC128 & -22.7 .7 & -240.9 & -.31 .5 .6 \\
\hline MPCMS Ag/AgCI & -6.3 & & \\
\hline MPCMS Calomel & & 27.9 & \\
\hline $\begin{array}{l}\text { MPCMS } \\
\text { Cu/CuSO }\end{array}$ & & & 15.5 \\
\hline
\end{tabular}

This page may be reproduced as necessary.

C-2

Page

of 
RPP-RPT-44463, Rev. 0

RPP-PLAN-43915, Rev. 0

241-AN-107 Simulant

DATE: $2 / 13 / 10$ TIME: 100 , T TEMP:

$620^{\circ} \mathrm{C}$

$\frac{61.20}{600}$

$\mathrm{pH}:$

ASTM A537 Electrode vs. Immersed MPCMS Reference Electrodes

\begin{tabular}{|l|c|c|c|}
\hline & $\begin{array}{c}\text { MPCMS } \\
\text { Ag/AgCI }\end{array}$ & $\begin{array}{c}\text { MPCMS } \\
\text { Calomel }\end{array}$ & $\begin{array}{c}\text { MPCMS } \\
\text { Cu/CuSO }\end{array}$ \\
\hline ASTM A537 & -2329 & -288.2 & -.39 .0 \\
\hline
\end{tabular}

Test Electrodes vs. Room Temperature MPCMS Reference Electrodes

\begin{tabular}{|l|c|c|c|}
\hline & $\begin{array}{c}\text { MPCMS } \\
\text { Ag/AgCl }\end{array}$ & $\begin{array}{c}\text { MPCMS } \\
\text { Calomel }\end{array}$ & $\begin{array}{c}\text { MPCMIS } \\
\text { Cu/CuSO }\end{array}$ \\
\hline ASTM A537 & -236.0 & -27.8 & $-35 \% 0$ \\
\hline $\begin{array}{l}\text { MPCMS } \\
\text { Ag/AgCl }\end{array}$ & 6.8 & & \\
\hline $\begin{array}{l}\text { MPCMS } \\
\text { Calomel }\end{array}$ & & 7.8 & \\
\hline $\begin{array}{l}\text { MPCMS } \\
\text { Cu/CuSO }\end{array}$ & & & 290 \\
\hline
\end{tabular}

Test Electrodes vs. Room Temperature Laboratory-Grade Reference Electrodes

\begin{tabular}{|l|c|c|c|}
\hline & $\begin{array}{c}\text { Laboratory } \\
\text { Ag/AgCl }\end{array}$ & $\begin{array}{c}\text { Laboratory } \\
\text { Calomel }\end{array}$ & $\begin{array}{c}\text { Laboratory } \\
\text { Cu/CuSO4 }\end{array}$ \\
\hline ASTM A537 & -248.6 & 27.5 .0 & -34.4 \\
\hline $\begin{array}{l}\text { MPCMS } \\
\text { Ag/AgCl }\end{array}$ & -20.7 & & \\
\hline $\begin{array}{l}\text { MPCMS } \\
\text { Calomel }\end{array}$ & & 4.1 & \\
\hline $\begin{array}{l}\text { MPCMS } \\
\text { Cu/CuSO }\end{array}$ & & & 37.5 \\
\hline
\end{tabular}

This page may be reproduced as necessary

C-3

Page

of 


\section{RPP-RPT-44463, Rev. 0}

RPP-PLAN-43915, Rev. 0

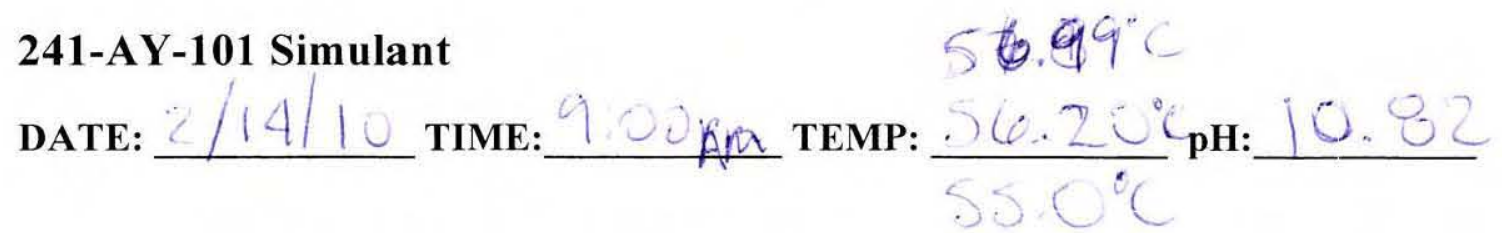

AAR TC128 Electrode vs. Immersed MPCMS Reference Electrodes

\begin{tabular}{|l|c|c|c|}
\hline & $\begin{array}{c}\text { MPCMS } \\
\text { Ag/AgCl }\end{array}$ & $\begin{array}{c}\text { MPCMS } \\
\text { Calomel }\end{array}$ & $\begin{array}{c}\text { MPCMIS } \\
\mathbf{C u} / \mathbf{C u S O}\end{array}$ \\
\hline AAR TC128 & 190.0 & -245.8 & -290.4 \\
\hline
\end{tabular}

Test Electrodes vs. Room Temperature MPCMS Reference Electrodes

\begin{tabular}{|l|c|c|c|}
\hline & $\begin{array}{c}\text { MPCMS } \\
\text { Ag/AgCl }\end{array}$ & $\begin{array}{c}\text { MPCMS } \\
\text { Calomel }\end{array}$ & $\begin{array}{c}\text { MPCMIS } \\
\text { Cu/CuSO }\end{array}$ \\
\hline AAR TC128 & $-178,7$ & 220.4 & 293.7 \\
\hline $\begin{array}{l}\text { MPCMS } \\
\text { Ag/AgCl }\end{array}$ & 10.4 & & \\
\hline $\begin{array}{l}\text { MPCMS } \\
\text { Calomel }\end{array}$ & & $2.4 \ldots$ & \\
\hline $\begin{array}{l}\text { MPCMS } \\
\text { Cu/CuSO }\end{array}$ & & & -4.6 \\
\hline
\end{tabular}

Test Electrodes vs. Room Temperature Laboratory-Grade Reference Electrodes

\begin{tabular}{|l|c|c|c|}
\hline & $\begin{array}{c}\text { Laboratory } \\
\text { Ag/AgCl }\end{array}$ & $\begin{array}{c}\text { Laboratory } \\
\text { Calomel }\end{array}$ & $\begin{array}{c}\text { Laboratory } \\
\text { Cu/CuSO4 }\end{array}$ \\
\hline AAR TC128 & -14.7 & -218.4 & -285.4 \\
\hline MPCMS Ag/AgCI & -3.6 & & \\
\hline MPCMS Calomel & & 2.5 .8 & 3.4 \\
\hline $\begin{array}{l}\text { MPCMS } \\
\text { Cu/CuSO }\end{array}$ & & & \\
\hline
\end{tabular}

This page may be reproduced as necessary.

C-2

Page

of 
RPP-RPT-44463, Rev. 0

$$
\text { RPP-PLAN-43915, Rev. } 0
$$

\section{1-AN-107 Simulant}

$$
56.99
$$

DATE: TIME: iCAZ TEMP:

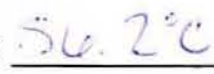
pH: ASTM A537 Electrode vs. Immersed MPCMS Reference Electrodes

\begin{tabular}{|l|c|c|c|}
\hline & $\begin{array}{c}\text { MPCMS } \\
\text { Ag/AgCl }\end{array}$ & $\begin{array}{c}\text { MPCMS } \\
\text { Calomel }\end{array}$ & $\begin{array}{c}\text { MPCMIS } \\
\text { Cu/CuSO4 }\end{array}$ \\
\hline ASTM A537 & -2347 & -2884 & -372.8 \\
\hline
\end{tabular}

Test Electrodes vs. Room Temperature MPCMS Reference Electrodes

\begin{tabular}{|l|c|c|c|}
\hline & $\begin{array}{c}\text { MPCMS } \\
\text { Ag/AgCl }\end{array}$ & $\begin{array}{c}\text { MPCMS } \\
\text { Calomel }\end{array}$ & $\begin{array}{r}\text { MPCMIS } \\
\text { Cu/CuSO }\end{array}$ \\
\hline ASTM A537 & 2 & & \\
\hline $\begin{array}{l}\text { MPCMS } \\
\text { Ag/AgCl }\end{array}$ & & 4 & \\
\hline $\begin{array}{l}\text { MPCMS } \\
\text { Calomel }\end{array}$ & & & \\
\hline $\begin{array}{l}\text { MPCMS } \\
\text { Cu/CuSO }\end{array}$ & & & \\
\hline
\end{tabular}

\begin{tabular}{|c|c|c|c|}
\hline & $\begin{array}{c}\text { Laboratory } \\
\text { Ag/AgCl }\end{array}$ & $\begin{array}{c}\text { Laboratory } \\
\text { Calomel }\end{array}$ & $\begin{array}{l}\text { Laboratory } \\
\mathrm{Cu} / \mathrm{CuSO}_{4}\end{array}$ \\
\hline ASTM A537 & -2524 & -270.0 & $-34+3$ \\
\hline $\begin{array}{l}\text { MPCMS } \\
\mathrm{Ag} / \mathrm{AgCl}\end{array}$ & -20.4 & & \\
\hline $\begin{array}{l}\text { MPCMS } \\
\text { Calomel }\end{array}$ & & 6.3 & \\
\hline $\begin{array}{l}\text { MPCMS } \\
\mathrm{Cu} / \mathrm{CuSO}_{4}\end{array}$ & & & 31.3 \\
\hline
\end{tabular}

Test Electrodes vs. Room Temperature Laboratory-Grade Reference Electrodes

This page may be reproduced as necessary of 


\section{RPP-RPT-44463, Rev. 0}

RPP-PLAN-43915, Rev. 0

\section{1-AY-101 Simulant}

DATE: $2 / 14 / 10$ TIME: $10.40 / \mathrm{m}$ TEMP:
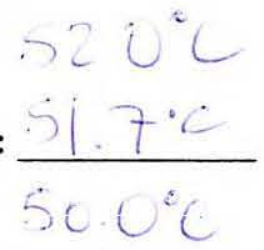

$\mathrm{pH}:$

AAR TC128 Electrode vs. Immersed MPCMS Reference Electrodes

\begin{tabular}{|l|c|c|c|}
\hline & $\begin{array}{c}\text { MPCMS } \\
\text { Ag/AgCl }\end{array}$ & $\begin{array}{c}\text { MPCMS } \\
\text { Calomel }\end{array}$ & $\begin{array}{c}\text { MPCMIS } \\
\text { Cu/CuSO }\end{array}$ \\
\hline AAR TC128 & -181.4 & 2.35 .1 & -278.4 \\
\hline
\end{tabular}

Test Electrodes vs. Room Temperature MPCMS Reference Electrodes

\begin{tabular}{|l|c|c|c|}
\hline & $\begin{array}{c}\text { MPCMS } \\
\text { Ag/AgCl }\end{array}$ & $\begin{array}{c}\text { MPCMS } \\
\text { Calomel }\end{array}$ & $\begin{array}{c}\text { MPCMS } \\
\text { Cu/CuSO }\end{array}$ \\
\hline AAR TC128 & -170.1 & -211.8 & -285.3 \\
\hline $\begin{array}{l}\text { MPCMS } \\
\text { Ag/AgCI }\end{array}$ & 10.9 & & \\
\hline $\begin{array}{l}\text { MPCMS } \\
\text { Calomel }\end{array}$ & & 22.7 & \\
\hline $\begin{array}{l}\text { MPCMS } \\
\text { Cu/CuSO }\end{array}$ & & & -7.7 \\
\hline
\end{tabular}

Test Electrodes vs. Room Temperature Laboratory-Grade Reference Electrodes

\begin{tabular}{|l|c|c|c|}
\hline & $\begin{array}{c}\text { Laboratory } \\
\text { Ag/AgCl }\end{array}$ & $\begin{array}{c}\text { Laboratory } \\
\text { Calomel }\end{array}$ & $\begin{array}{c}\text { Laboratory } \\
\text { Cu/CuSO }\end{array}$ \\
\hline AAR TC128 & -124.1 & 29.9 & -276.8 \\
\hline MPCMS Ag/AgCl & 3.5 & & \\
\hline MPCMS Calomel & & 24.1 & \\
\hline $\begin{array}{l}\text { MPCMS } \\
\text { Cu/CuSO }\end{array}$ & & & 0.5 \\
\hline
\end{tabular}

This page may be reproduced as necessary.

of 


$$
\text { RPP-RPT-44463, Rev. } 0
$$

$$
\text { RPP-PLAN-43915, Rev. } 0
$$

\section{1-AN-107 Simulant}
DATE: TIME: $1045 \pi$ TEMP: $517^{s c}$ pH: 10.13 ASTM A537 Electrode vs. Immersed MPCMS Reference Electrodes

\begin{tabular}{|l|c|c|c|}
\hline & $\begin{array}{c}\text { MPCMS } \\
\text { Ag/AgCI }\end{array}$ & $\begin{array}{c}\text { MPCMS } \\
\text { Calomel }\end{array}$ & $\begin{array}{c}\text { MPCMIS } \\
\text { Cu/CuSO }\end{array}$ \\
\hline ASTM A537 & 2.32 .9 & -28.3 .3 & -364.5 \\
\hline
\end{tabular}

Test Electrodes vs. Room Temperature MPCMS Reference Electrodes

\begin{tabular}{|l|c|c|c|}
\hline & $\begin{array}{c}\text { MPCMS } \\
\text { Ag/AgCI }\end{array}$ & $\begin{array}{c}\text { MPCMS } \\
\text { Calomel }\end{array}$ & $\begin{array}{c}\text { MPCMIS } \\
\text { Cu/CuSO }\end{array}$ \\
\hline ASTM A537 & -2.2 .2 & -276.4 & -34.4 \\
\hline $\begin{array}{l}\text { MPCMS } \\
\text { Ag/AgCl }\end{array}$ & -4 & & \\
\hline $\begin{array}{l}\text { MPCMS } \\
\text { Calomel }\end{array}$ & & 3.6 & \\
\hline $\begin{array}{l}\text { MPCMS } \\
\text { Cu/CuSO }\end{array}$ & & & 2.9 \\
\hline
\end{tabular}

Test Electrodes vs. Room Temperature Laboratory-Grade Reference Electrodes

\begin{tabular}{|l|c|c|c|}
\hline & $\begin{array}{c}\text { Laboratory } \\
\text { Ag/AgCl }\end{array}$ & $\begin{array}{c}\text { Laboratory } \\
\text { Calomel }\end{array}$ & $\begin{array}{c}\text { Laboratory } \\
\text { Cu/CuSO }\end{array}$ \\
\hline ASTM A537 & -27.2 & -272.6 & $-3.3 \% .1$ \\
\hline $\begin{array}{l}\text { MPCMS } \\
\text { Ag/AgCl }\end{array}$ & -20.2 & & \\
\hline $\begin{array}{l}\text { MPCMS } \\
\text { Calomel }\end{array}$ & & 4.9 & \\
\hline $\begin{array}{l}\text { MPCMS } \\
\text { Cu/CuSO }\end{array}$ & & & 2.9 \\
\hline
\end{tabular}

This page may be reproduced as necessary of 


\section{1-AY-101 Simulant}

DATE: TIME:

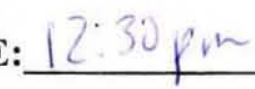

TEMP:

He. $9^{\circ} \mathrm{C}$

$\mathrm{pH}:$

$4 \div 0^{\circ} \mathrm{C}$

AAR TC128 Electrode vs. Immersed MPCMS Reference Electrodes

\begin{tabular}{|l|c|c|c|}
\hline & $\begin{array}{c}\text { MPCMS } \\
\mathbf{A g} / \mathbf{A g C l}\end{array}$ & $\begin{array}{c}\text { MPCMS } \\
\text { Calomel }\end{array}$ & $\begin{array}{c}\text { MPCMS } \\
\mathbf{C u} / \mathbf{C u S O}_{4}\end{array}$ \\
\hline AAR TC128 & -173.9 & -225.2 & -268.6 \\
\hline
\end{tabular}

Test Electrodes vs. Room Temperature MPCMS Reference Electrodes

\begin{tabular}{|l|c|c|c|}
\hline & $\begin{array}{c}\text { MPCMS } \\
\text { Ag/AgCl }\end{array}$ & $\begin{array}{c}\text { MPCMS } \\
\text { Calomel }\end{array}$ & $\begin{array}{c}\text { MPCMS } \\
\text { Cu/CuSO }\end{array}$ \\
\hline AAR TC128 & -160.9 & -20.3 .1 & -276.8 \\
\hline $\begin{array}{l}\text { MPCMS } \\
\text { Ag/AgCl }\end{array}$ & 11.4 & & \\
\hline $\begin{array}{l}\text { MPCMS } \\
\text { Calomel }\end{array}$ & & 20.7 & \\
\hline $\begin{array}{l}\text { MPCMS } \\
\text { Cu/CuSO }_{4}\end{array}$ & & & -10.2 \\
\hline
\end{tabular}

Test Electrodes vs. Room Temperature Laboratory-Grade Reference Electrodes

\begin{tabular}{|l|c|c|c|}
\hline & $\begin{array}{c}\text { Laboratory } \\
\text { Ag/AgCl }\end{array}$ & $\begin{array}{c}\text { Laboratory } \\
\text { Calomel }\end{array}$ & $\begin{array}{c}\text { Laboratory } \\
\text { Cu/CuSO }\end{array}$ \\
\hline AAR TC128 & -175.0 & -201.4 & -2689 \\
\hline MPCMS Ag/AgCl & -2.7 & & \\
\hline MPCMS Calomel & & 22.1 & \\
\hline $\begin{array}{l}\text { MPCMS } \\
\text { Cu/CuSO }\end{array}$ & & & -2.5 \\
\hline
\end{tabular}

This page may be reproduced as necessary. of 
RPP-RPT-44463, Rev. 0

RPP-PLAN-43915, Rev. 0

\section{1-AN-107 Simulant}

DATE: $2 / 11 / 10$ TIME 2 \& $\mathrm{pm}$ TEMP: $\frac{46^{\circ} .9^{\circ} \mathrm{C}}{4.5 .0^{\circ} \mathrm{C}}$ pH: 10.29

ASTM A537 Electrode vs. Immersed MPCMS Reference Electrodes

\begin{tabular}{|l|c|c|c|}
\hline & $\begin{array}{c}\text { MPCMS } \\
\text { Ag/AgCl }\end{array}$ & $\begin{array}{c}\text { MPCMS } \\
\text { Calomel }\end{array}$ & $\begin{array}{c}\text { MPCMS } \\
\mathbf{C u}_{\text {/CuSO }}\end{array}$ \\
\hline ASTM A537 & -227.8 & -276.3 & -355.3 \\
\hline
\end{tabular}

Test Electrodes vs. Room Temperature MPCMS Reference Electrodes

\begin{tabular}{|l|c|c|c|}
\hline & $\begin{array}{c}\text { MPCMS } \\
\text { Ag/AgCI }\end{array}$ & $\begin{array}{c}\text { MPCMS } \\
\text { Calomel }\end{array}$ & $\begin{array}{c}\text { MPCMS } \\
\text { Cu/CuSO }\end{array}$ \\
\hline ASTM A537 & -2.30 .9 & -274.9 & -344.3 \\
\hline $\begin{array}{l}\text { MPCMS } \\
\text { Ag/AgCI }\end{array}$ & -5.7 & & \\
\hline $\begin{array}{l}\text { MPCMS } \\
\text { Calomel }\end{array}$ & & 1.9 & \\
\hline $\begin{array}{l}\text { MPCMS } \\
\text { Cu/CuSO }\end{array}$ & & & 7.6 \\
\hline
\end{tabular}

Test Electrodes vs. Room Temperature Laboratory-Grade Reference Electrodes

\begin{tabular}{|l|c|c|c|}
\hline & $\begin{array}{c}\text { Laboratory } \\
\text { Ag/AgCl }\end{array}$ & $\begin{array}{c}\text { Laboratory } \\
\text { Calomel }\end{array}$ & $\begin{array}{c}\text { Laboratory } \\
\text { Cu/CuSO }\end{array}$ \\
\hline ASTM A537 & 242.2 & -268.1 & 35.2 \\
\hline $\begin{array}{l}\text { MPCMS } \\
\text { Ag/AgCl }\end{array}$ & -19.8 & & \\
\hline $\begin{array}{l}\text { MPCMS } \\
\text { Calomel }\end{array}$ & & 3.2 & \\
\hline $\begin{array}{l}\text { MPCMS } \\
\text { Cu/CuSO }\end{array}$ & & & 25.1 \\
\hline
\end{tabular}

This page may be reproduced as necessary

of 
RPP-RPT-44463, Rev. 0

RPP-PLAN-43915, Rev. 0

241-AY-101 Simulant

DATE: $2115 / 1$ TIME: 1.20 AM TEMP:

$4 k^{9} 9^{2} \mathrm{C}$

$\frac{4+23}{450}$

$\mathrm{pH}: \underline{10.94}$

AAR TC128 Electrode vs. Immersed MPCMS Reference Electrodes

\begin{tabular}{|l|c|c|c|}
\hline & $\begin{array}{c}\text { MPCMS } \\
\text { Ag/AgCl }\end{array}$ & $\begin{array}{c}\text { MPCMS } \\
\text { Calomel }\end{array}$ & $\begin{array}{c}\text { MPCMS } \\
\mathbf{C u} / \mathbf{C u S O}_{4}\end{array}$ \\
\hline AAR TC128 & -175.3 & -224.7 & -273.1 \\
\hline
\end{tabular}

Test Electrodes vs. Room Temperature MPCMS Reference Electrodes

\begin{tabular}{|l|c|c|c|}
\hline & $\begin{array}{c}\text { MPCMS } \\
\text { Ag/AgCl }\end{array}$ & $\begin{array}{c}\text { MPCMS } \\
\text { Calomel }\end{array}$ & $\begin{array}{c}\text { MPCMS } \\
\text { Cu/CuSO }\end{array}$ \\
\hline AAR TC128 & -16.8 & -205.5 & $-279,9$ \\
\hline $\begin{array}{l}\text { MPCMS } \\
\text { Ag/AgCl }\end{array}$ & $10, c_{1}$ & & \\
\hline $\begin{array}{l}\text { MPCMS } \\
\text { Calomel }\end{array}$ & & 18,7 & \\
\hline $\begin{array}{l}\text { MPCMS } \\
\text { Cu/CuSO }\end{array}$ & & & 6.6. \\
\hline
\end{tabular}

Test Electrodes vs. Room Temperature Laboratory-Grade Reference Electrodes

\begin{tabular}{|l|c|c|c|}
\hline & $\begin{array}{c}\text { Laboratory } \\
\text { Ag/AgCl }\end{array}$ & $\begin{array}{c}\text { Laboratory } \\
\text { Calomel }\end{array}$ & $\begin{array}{c}\text { Laboratory } \\
\text { Cu/CuSO }\end{array}$ \\
\hline AAR TC128 & -177.8 & 2037 & -273.7 \\
\hline MPCMS Ag/AgCl & -3.1 & & \\
\hline MPCMS Calomel & & $2 C .2$ & \\
\hline $\begin{array}{l}\text { MPCMS } \\
\text { Cu/CuSO }\end{array}$ & & & 1.4 \\
\hline
\end{tabular}

This page may be reproduced as necessary.

C-2

Page

of 


$$
\begin{aligned}
& \text { RPP-RPT-44463, Rev. } 0 \\
& \text { RPP-PLAN-43915, Rev. } 0
\end{aligned}
$$

241-AN-107 Simulant

DATE: $2 / 15 / 10$ TIME: $\frac{9: 25}{40.0^{\circ} \mathrm{C}}$ TEP: $\frac{413^{\circ}}{40.04}$

ASTM A537 Electrode vs. Immersed MPCMS Reference Electrodes

\begin{tabular}{|l|c|c|c|}
\hline & $\begin{array}{c}\text { MPCMS } \\
\text { Ag/AgCl }\end{array}$ & $\begin{array}{c}\text { MPCMS } \\
\text { Calomel }\end{array}$ & $\begin{array}{c}\text { MPCMS } \\
\mathbf{C u} / \mathbf{C u S O}_{4}\end{array}$ \\
\hline ASTM A537 & -204.8 & -252.5 & -322.6 \\
\hline
\end{tabular}

Test Electrodes vs. Room Temperature MPCMS Reference Electrodes

\begin{tabular}{|l|c|c|c|}
\hline & $\begin{array}{c}\text { MPCMS } \\
\text { Ag/AgCl }\end{array}$ & $\begin{array}{c}\text { MPCMS } \\
\text { Calomel }\end{array}$ & $\begin{array}{c}\text { MPCMS } \\
\text { Cu/CuSO }\end{array}$ \\
\hline ASTM A537 & 208.4 & 249.5 & -322.5 \\
\hline $\begin{array}{l}\text { MPCMS } \\
\text { Ag/AgCl }\end{array}$ & 6,2 & & \\
\hline $\begin{array}{l}\text { MPCMS } \\
\text { Calomel }\end{array}$ & & 0.7 & \\
\hline $\begin{array}{l}\text { MPCMS } \\
\text { Cu/CuSO }\end{array}$ & & & 12.1 \\
\hline
\end{tabular}

Test Electrodes vs. Room Temperature Laboratory-Grade Reference Electrodes

\begin{tabular}{|l|c|c|c|}
\hline & $\begin{array}{c}\text { Laboratory } \\
\text { Ag/AgCl }\end{array}$ & $\begin{array}{c}\text { Laboratory } \\
\text { Calomel }\end{array}$ & $\begin{array}{c}\text { Laboratory } \\
\text { Cu/CuSO }\end{array}$ \\
\hline ASTM A537 & 220.3 & $24 \% .2$ & 315.5 \\
\hline $\begin{array}{l}\text { MPCMS } \\
\text { Ag/AgCl }\end{array}$ & 20.3 & & \\
\hline $\begin{array}{l}\text { MPCMS } \\
\text { Calomel }\end{array}$ & & 2.2 & \\
\hline $\begin{array}{l}\text { MPCMS } \\
\text { Cu/CuSO }\end{array}$ & & & 17, \\
\hline
\end{tabular}

This page may be reproduced as necessary

C-3

Page

of 
RPP-RPT-44463, Rev. 0

RPP-PLAN-43916, Rev. 0

\section{1-AY-101 Simulant}

\section{Initial (Back of Electrodes Dry)}

DATE: $215 / 2010$ TIME: $11: 30$ TEMP: $\frac{25 / 26}{25.0} \mathrm{pH}: 12.15$

Immersed AAR TC128 and Secondary Electrodes vs. Immersed MPCMS Reference Electrodes

\begin{tabular}{|l|l|l|l|l|}
\hline \multicolumn{1}{|c|}{ red } & $\begin{array}{c}\text { MPCMS } \\
\text { Ag/AgCl }\end{array}$ & $\begin{array}{c}\text { MPCMS } \\
\text { Calomel }\end{array}$ & $\begin{array}{c}\text { MPCMS } \\
\text { Cu/CuSO }\end{array}$ \\
\cline { 2 - 6 } AAR TC128 & -168.6 & -208.9 & -335.4 \\
Ans & -270.2 \\
\cline { 2 - 6 } & Cu Secondary & -269.2 & -335.4 & -397.1 \\
\cline { 2 - 6 } & Ni Secondary & -28.0 & -246.5 & -306.7 \\
\hline Ag Secondary & -93.1 & -244.0 & -194.0 \\
\hline
\end{tabular}

Immersed Test Electrodes vs. Room Temperature MPCMS Reference Electrodes

\begin{tabular}{|c|c|c|c|c|c|}
\hline & $\begin{array}{l}\text { MPCMS } \\
\text { Ag/AgCl } \\
\end{array}$ & $\begin{array}{l}\text { MPCMS } \\
\text { Calomel }\end{array}$ & $\begin{array}{c}\mathrm{MPCMS} \\
\mathrm{Cu} / \mathrm{CuSO}_{4}\end{array}$ & Sheoth & \\
\hline AAR TC128 & -162.6 & -203.7 & -273.0 & 茾年: & +24.8 \\
\hline Cu Secondary & -286.5 & -329.3 & -398.5 & $89-5$ & -89.2 \\
\hline Ni Secondary & -201.9 & -241.5 & -309.6 & 5.5 .1 & -4 \\
\hline Ag Secondary & -85.6 & -126.5 & -195.0 & -1127.0 & 105.0 \\
\hline MPCMS Ag/AgCl & +6.7 & & & & \\
\hline $\begin{array}{l}\text { MPCMS Calomel } \\
\text { MPCMS Cu/CuSO }_{4}\end{array}$ & & +5.0 & -2.5 & & \\
\hline
\end{tabular}

Immersed Test Electrodes vs. Room Temperature Laboratory-Grade Reference Electrodes

\begin{tabular}{|l|l|l|l|}
\hline & $\begin{array}{c}\text { Laboratory } \\
\text { Ag/AgCl }\end{array}$ & $\begin{array}{c}\text { Laboratory } \\
\text { Calomel }\end{array}$ & $\begin{array}{c}\text { Laboratory } \\
\text { Cu/CuSO }\end{array}$ \\
\hline AAR TC128 & -173 & -201.7 & -269.6 \\
\hline Cu Secondary & -298.6 & -327.4 & -356.0 \\
\hline Ni Secondary & -222.5 & -246.8 & -313.1 \\
\hline Ag Secondary & -95.9 & -124.3 & -192.0 \\
\hline MPCMS Ag/AgCl & -3.9 & & \\
\hline MPCMS Calomel & & +7.0 & \\
\hline MPCMS Cu/CuSO & & & 0.5 \\
\hline
\end{tabular}

This page may be reproduced as necessary

$\mathrm{C}-2$

Page 1 of 
RPP-RPT-44463, Rev. 0

RPP-PLAN-43916, Rev. 0

\section{1-AN-107 Simulant}

Initial (Back of Electrodes Dry)

DATE: $215 / 2010$ TIME: $\frac{11: 30}{25.0}$ TEMP: $\frac{25 / 26.1}{25: 10.67}$

Immersed ASTM A537 and Secondary Electrodes vs.

Immersed MPCMS Reference Electrodes

\begin{tabular}{|l|l|l|l|}
\hline & $\begin{array}{c}\text { MPCMS } \\
\text { Ag/AgCl }\end{array}$ & $\begin{array}{c}\text { MPCMS } \\
\text { Calomel }\end{array}$ & $\begin{array}{c}\text { MPCMS } \\
\text { Cu/CuSO }\end{array}$ \\
\hline ASTM A537 & -270.1 & -312.5 & +86.8 \\
\hline Cu Secondary & -341.5 & -387.2 & +10.6 \\
\hline Ni Secondary & -298.6 & -344.5 & +537 \\
\hline Ag Secondary & -153.2 & -198.7 & +198.2 \\
\hline
\end{tabular}

Immersed Test Electrodes vs. Room Temperature MPCMS Reference Electrodes

\begin{tabular}{|c|c|c|c|c|c|}
\hline 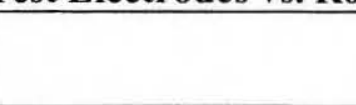 & $\begin{array}{l}\text { MPCMS } \\
\text { Ag/AgCl }\end{array}$ & $\begin{array}{l}\text { MPCMS } \\
\text { Calomel }\end{array}$ & $\begin{array}{c}\mathrm{MPCMS}_{\mathrm{Cu} / \mathrm{CuSO}_{4}} \\
\mathrm{CuSO}\end{array}$ & eats & {$[m V]$} \\
\hline ASTM A537 & -274.4 & $-315 \cdot 2$ & -383.4 & $+235+54$ & \\
\hline Cu Secondary & -346.4 & -388.3 & -4573 & -294.5 & 122.0 \\
\hline Ni Secondary & -302.1 & -344.4 & $-413 \cdot 4$ & $1-43.0$ & +15.5 \\
\hline Ag Secondary & -159.5 & $-20+2$ & -270.2 & +244.0 & \\
\hline MPCMS Ag/AgCl & -6.5 & & & & \\
\hline MPCMS Calomel & & -2.5 & & & \\
\hline $\mathrm{MPCMS} \mathrm{Cu} / \mathrm{CuSO}_{4}$ & & & -469.5 & & \\
\hline
\end{tabular}

Immersed Test Electrodes vs. Room Temperature Laboratory-Grade Reference Electrodes

\begin{tabular}{|l|c|c|c|}
\hline & $\begin{array}{c}\text { Laboratory } \\
\text { Ag/AgCl }\end{array}$ & $\begin{array}{c}\text { Laboratory } \\
\text { Calomel }\end{array}$ & $\begin{array}{c}\text { Laboratory } \\
\text { Cu/CuSO}\end{array}$ \\
\hline ASTM A537 & -283.5 & -311.5 & -380.0 \\
\hline Cu Secondary & -358.5 & -387.7 & -456.5 \\
\hline Ni Secondary & -313.6 & -343.0 & -412.8 \\
\hline Ag Secondary & -170.3 & -199.1 & -267.5 \\
\hline MPCMS Ag/AgCl & -17.8 & & \\
\hline MPCMS Calomel & & -1.28 & \\
\hline MPCMS Cu/CuSO $_{4}$ & & & -469.3 \\
\hline
\end{tabular}

probe had wostem lealage. meas@2:35pm.2mV

This page may be reproduced as necessary

Page 2 of 
RPP-RPT-44463, Rev. 0

RPP-PLAN-43916, Rev. 0

241-AY-101 Simulant

Wetted With Water
(22.8)

25.0

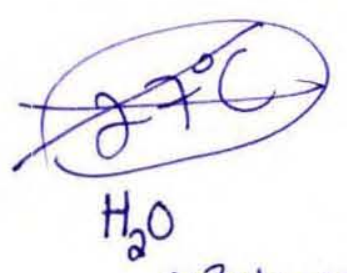

$\sim 3 m b i n$ each

DATE: $2 / 5 / 2010$ TIME: $2: 35$ TEMP: $23.6 \quad \mathrm{pH}: 10.58$

Immersed AAR TC128 and Secondary Electrodes vs.

Immersed MPCMS Reference Electrodes

\begin{tabular}{|l|c|c|c|}
\hline & $\begin{array}{c}\text { MPCMS } \\
\text { Ag/AgCI }\end{array}$ & $\begin{array}{c}\text { MPCMS } \\
\text { Calomel }\end{array}$ & $\begin{array}{c}\text { MPCMS } \\
\text { Cu/CuSO }\end{array}$ \\
\hline AAR TC128 & -193.5 & -299.9 & -393.8 \\
\hline Cu Secondary & -193.6 & -389.8 & -48.6 \\
\hline Ni Secondary & -329.5 & -443.8 & -537.3 \\
\hline Ag Secondary & -204.4 & -312.2 & -406.6 \\
\hline
\end{tabular}

Immersed Test Electrodes vs. Room Temperature MPCMS Reference Electrodes

\begin{tabular}{|c|c|c|c|c|}
\hline & $\begin{array}{l}\text { MPCMS } \\
\text { Ag/AgCl } \\
\end{array}$ & $\begin{array}{l}\text { MPCMS } \\
\text { Calomel } \\
\end{array}$ & $\begin{array}{c}\text { MPCMS } \\
{\mathrm{Cu} / \mathrm{CuSO}_{4}}_{4}\end{array}$ & shegth \\
\hline AAR TC128 & -379.5 & -429.5 & -4004 & -236.6 \\
\hline Cu Secondary & -288.9 & -308.3 & -399.2 & -151.4 \\
\hline Ni Secondary & -433.9 & -475.6 & 524.1 & -0600.0 \\
\hline Ag Secondary & -301.4 & -343.0 & $-4 / 2.0$ & -173.6 \\
\hline MPCMS Ag/AgCl & -102.6 & & & -44.1 \\
\hline MPCMS Calomel & & -18.0 & & +56.8 \\
\hline 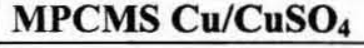 & & & -7.57 & +219.5 \\
\hline
\end{tabular}

Immersed Test Electrodes vs. Room Temperature Laboratory-Grade Reference Electrodes

\begin{tabular}{|c|c|c|c|}
\hline & $\begin{array}{c}\text { Laboratory } \\
\text { Ag/AgCl }\end{array}$ & $\begin{array}{c}\text { Laboratory } \\
\text { Calomel }\end{array}$ & $\begin{array}{l}\text { Laboratory } \\
\mathrm{Cu} / \mathrm{CuSO}_{4}\end{array}$ \\
\hline AAR TC128 & -388.2 & -414.9 & $-4004-50$ \\
\hline Cu Secondary & -300.3 & -470.5 & -399.8 \\
\hline Ni Secondary & -439.9 & \multicolumn{2}{|c|}{$-4717^{-324.1}-541.9$} \\
\hline Ag Secondary & -309.1 & -338.4 & -409.4 \\
\hline MPCMS Ag/AgCl & -105.4 & & \\
\hline MPCMS Calomel & & -30.6 & \\
\hline $\mathrm{MPCMS} \mathrm{Cu} / \mathrm{CuSO}_{4}$ & & & -7.00 \\
\hline
\end{tabular}

This page may be reproduced as necessary

C-4

Page 3 of 


\section{1-AN-107 Simulant}

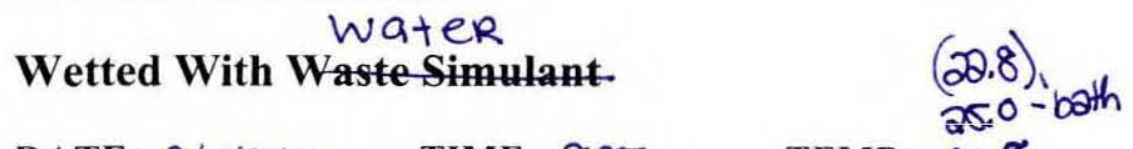

DATE: $2 / 5 / 2010$ TIME: 2.35 TEMP: 23.8 pH: 12.00

Immersed ASTM A537 and Secondary Electrodes vs. Immersed MPCMS Reference Electrodes

\begin{tabular}{|l|l|l|l|}
\hline & $\begin{array}{c}\text { MPCMS } \\
\text { Ag/AgCl }\end{array}$ & $\begin{array}{c}\text { MPCMS } \\
\text { Calomel }\end{array}$ & $\begin{array}{c}\text { MPCMS } \\
\text { Cu/CuSO }\end{array}$ \\
\hline ASTM A537 & -390.8 & -394.0 & -360.6 \\
\hline Cu Secondary & -341.4 & -347.3 & -300.0 \\
\hline Ni Secondary & -332.9 & -3970 & -297.0 \\
\hline Ag Secondary & -350.1 & -336.4 & -351 \\
\hline
\end{tabular}

Immersed Test Electrodes vs. Room Temperature MPCMS Reference Electrodes

\begin{tabular}{|l|l|l|l|l|}
\hline & $\begin{array}{l}\text { MPCMS } \\
\text { Ag/AgCl }\end{array}$ & $\begin{array}{l}\text { MPCMS } \\
\text { Calomel }\end{array}$ & $\begin{array}{c}\text { MPCMS } \\
\text { Cu/CuSO }\end{array}$ & Sheath \\
\hline ASTM A537 & -4025 & -444.8 & -573.6 & -286.86 \\
\hline Cu Secondary & -349.1 & -357.9 & -465.9 & -312.2 \\
\hline Ni Secondary & -343.0 & -385.4 & -455.0 & -252.8 \\
\hline Ag Secondary & -358.7 & -357.8 & -468.9 & -286.4 \\
\hline MPCMS Ag/AgCl & -12.1 & & & +1.4 \\
\hline MPCMS Calomel & & -47.1 & & -20.6 .6 \\
\hline MPCMS Cu/CuSO & & & -157.4 & -76.01 \\
\hline
\end{tabular}

Immersed Test Electrodes vs. Room Temperature Laboratory-Grade Reference Electrodes

\begin{tabular}{|l|l|l|l|}
\hline & $\begin{array}{c}\text { Laboratory } \\
\text { Ag/AgCl }\end{array}$ & $\begin{array}{c}\text { Laboratory } \\
\text { Calomel }\end{array}$ & $\begin{array}{c}\text { Laboratory } \\
\text { Cu/CuSO }\end{array}$ \\
\hline ASTM A537 & -411.6 & -440.5 & -507.4 \\
\hline Cu Secondary & -363.8 & -392.9 & -463.7 \\
\hline Ni Secondary & -349.2 & -374.4 & -449.3 \\
\hline Ag Secondary & -361.9 & -402.7 & -475.3 \\
\hline MPCMS Ag/AgCl & -23.5 & & \\
\hline MPCMS Calomel & & -31.5 & \\
\hline MPCMS Cu/CuSO & & & -145.6 \\
\hline
\end{tabular}

This page may be reproduced as necessary

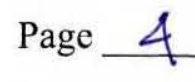
of 
Re-take

due to electroutes

241-AY-101 Simulant

clean after water

(26.9)

out of Solution uhile fixing

DATE: TIME: $5: 40$ pM TEMP: $\mathrm{CuCuSO}_{4}$

$\mathrm{pH}: 12.01$ $\frac{26.4}{25.0}$ Immersed AAR TC128 and Secondary Electrodes vs. Immersed MPCMS Reference Electrodes

\begin{tabular}{|l|l|l|l|}
\hline & $\begin{array}{l}\text { MPCMS } \\
\text { Ag/AgCl }\end{array}$ & $\begin{array}{l}\text { MPCMS } \\
\text { Calomel }\end{array}$ & $\begin{array}{l}\text { MPCMS } \\
\text { Cu/CuSO }\end{array}$ \\
\hline AAR TC128 & -158.7 & -212.3 & -143.2 \\
\hline Cu Secondary & -280.8 & -334.9 & -265.7 \\
\hline Ni Secondary & -188.2 & -242.1 & -176.9 \\
\hline Ag Secondary & -123.2 & -176.2 & -107.0 \\
\hline
\end{tabular}

Immersed Test Electrodes vs. Room Temperature MPCMS Reference Electrodes

\begin{tabular}{|l|l|l|l|l|}
\hline & $\begin{array}{l}\text { MPCMS } \\
\text { Ag/AgCl }\end{array}$ & $\begin{array}{l}\text { MPCMS } \\
\text { Calomel }\end{array}$ & $\begin{array}{l}\text { MPCMS } \\
\text { Cu/CuSO }\end{array}$ & Sheath \\
\hline AAR TC128 & -163.4 & -205.4 & -275.2 & +17.7 \\
\hline Cu Secondary & -286.0 & -328.2 & -398.3 & -104.2 \\
\hline Ni Secondary & -202.5 & -226.7 & -321.4 & -32.0 \\
\hline Ag Secondary & -127.0 & -169.9 & -238.9 & +60.3 \\
\hline MPCMS Ag/AgCl & -4.6 & & & 178.6 \\
\hline MPCMS Calomel & & +6.8 & & 2.31 .5 \\
\hline MPCMS Cu/CuSO & & & $-\$ 33133.0$ & 0.09 \\
\hline
\end{tabular}

113.6 201.0 * Needs to be cleaned

Immersed Test Electrodes vs. Room Temperature Laboratory-Grade Reference Electrodes Short cir.

\begin{tabular}{|l|l|l|l|}
\hline & $\begin{array}{l}\text { Laboratory } \\
\text { Ag/AgCl }\end{array}$ & $\begin{array}{l}\text { Laboratory } \\
\text { Calomel }\end{array}$ & $\begin{array}{l}\text { Laboratory } \\
\text { Cu/CuSO}_{4}\end{array}$ \\
\hline AAR TC128 & -177.1 & -205.0 & -275.3 \\
\hline Cu Secondary & -298.7 & -327.1 & -397.6 \\
\hline Ni Secondary & -233.0 & -260.8 & -330.2 \\
\hline Ag Secondary & -133.5 & -162.0 & -229.0 \\
\hline MPCMS Ag/AgCl & -18.0 & & \\
\hline MPCMS Calomel & & +8.2 & \\
\hline MPCMS Cu/CuSO & & & -130.6 \\
\hline
\end{tabular}

This page may be reproduced as necessary

Page 5 of 
241-AN-107 Simulant

clean afterwater

Wetted With Foam Component Liquid

DATE: $2 / 5 / 10$

TIME: 5:35PM TEMP
26.5
25.0

$\mathrm{pH}: 10.58$

Immersed ASTM A537 and Secondary Electrodes vs.

Immersed MPCMS Reference Electrodes

\begin{tabular}{|l|l|l|l|}
\hline & $\begin{array}{c}\text { MPCMS } \\
\text { Ag/AgCl }\end{array}$ & $\begin{array}{c}\text { MPCMS } \\
\text { Calomel }\end{array}$ & $\begin{array}{c}\text { MPCMS } \\
\text { Cu/CuSO }\end{array}$ \\
\hline ASTM A537 & -3 I 16.1 & -356.4 & -406.6 \\
\hline Cu Secondary & -341.9 & -382.1 & -432.7 \\
\hline Ni Secondary & -325.8 & -36.6 .4 & -416.9 \\
\hline Ag Secondary & -291.4 & -331.2 & -382.4 \\
\hline
\end{tabular}

Immersed Test Electrodes vs. Room Temperature MPCMS Reference Electrodes

\begin{tabular}{|l|l|l|l|l|}
\hline & $\begin{array}{l}\text { MPCMS } \\
\text { Ag/AgCl }\end{array}$ & $\begin{array}{c}\text { MPCMS } \\
\text { Calomel }\end{array}$ & $\begin{array}{c}\text { MPCMS } \\
\text { Cu/CuSO }\end{array}$ & Sheath \\
\hline ASTM A537 & -319.5 & -360.6 & -430.0 & -162.2 \\
\hline Cu Secondary & -335.7 & -387.4 & -456.6 & -159.9 \\
\hline Ni Secondary & -329.9 & -371.6 & -440.5 & -268.0 \\
\hline Ag Secondary & -295.0 & -336.9 & -406.2 & -129.8 \\
\hline MPCMS Ag/AgCl & -6.7 & & & +125.9 \\
\hline MPCMS Calomel & & -8.9 & & 0.001 \\
\hline MPCMS Cu/CuSO & & & -24.9 & +174.7 \\
\hline
\end{tabular}

Immersed Test Electrodes vs. Room Temperature Laboratory-Grade Reference Electrodes

\begin{tabular}{|l|c|c|c|}
\hline & $\begin{array}{c}\text { Laboratory } \\
\text { Ag/AgCl }\end{array}$ & $\begin{array}{c}\text { Laboratory } \\
\text { Calomel }\end{array}$ & $\begin{array}{c}\text { Laboratory } \\
\text { Cu/CuSO }\end{array}$ \\
\hline ASTM A537 & -331.5 & -359.1 & -428.8 \\
\hline Cu Secondary & -357.8 & -386.1 & -456.0 \\
\hline Ni Secondary & -341.1 & -369.4 & -438.8 \\
\hline Ag Secondary & -306.7 & -335.1 & -403.4 \\
\hline MPCMS Ag/AgCl & -18.5 & & \\
\hline MPCMS Calomel & & -7.7 & \\
\hline MPCMS Cu/CuSO $_{4}$ & & & -22.7 \\
\hline
\end{tabular}

This page may be reproduced as necessary

Page 6 of 
RPP-RPT-44463, Rev. 0

\section{1-AY-101 Simulant}

Back of Electrodes Dry after WatcR

DATE: $216 / 10$ TIME: $8: 35 \mathrm{am}$ TEMP:
(27.0)

$\frac{27.0}{25.0} \mathrm{pH}: 12.02$

Immersed AAR TC128 and Secondary Electrodes vs. Immersed MPCMS Reference Electrodes

\begin{tabular}{|l|l|l|l|}
\hline & $\begin{array}{c}\text { MPCMS } \\
\text { Ag/AgCl }\end{array}$ & $\begin{array}{c}\text { MPCMS } \\
\text { Calomel }\end{array}$ & $\begin{array}{c}\text { MPCMS } \\
\text { Cu/CuSO }\end{array}$ \\
\hline AAR TC128 & -164.2 & -212.0 & -273.7 \\
\hline Cu Secondary & -289.0 & -337.3 & -399.4 \\
\hline Ni Secondary & -200.2 & -247.0 & -307.6 \\
\hline Ag Secondary & -115.3 & -162.6 & -223.4 \\
\hline
\end{tabular}

Immersed Test Electrodes vs. Room Temperature MPCMS Reference Electrodes

\begin{tabular}{|l|l|l|l|l|}
\hline & $\begin{array}{c}\text { MPCMS } \\
\text { Ag/AgCI }\end{array}$ & $\begin{array}{c}\text { MPCMS } \\
\text { Calomel }\end{array}$ & $\begin{array}{c}\text { MPCMS } \\
\text { Cu/CuSO }\end{array}$ & $\begin{array}{c}\text { Electrode } \\
\text { Housing }\end{array}$ \\
\hline AAR TC128 & -160.9 & -202.8 & -274.3 & -35.3 \\
\hline Cu Secondary & -286.4 & -328.3 & -399.8 & -120.7 \\
\hline Ni Secondary & -194.1 & -236.2 & -307.3 & -30.1 \\
\hline Ag Secondary & -111.9 & -153.5 & -225.0 & +56.1 \\
\hline MPCMS Ag/AgCl & +2.5 & & & +119.7 \\
\hline MPCMS Calomel & & +8.5 & & +187.7 \\
\hline MPCMS Cu/CuSO & & & -1.6 & +256.5 \\
\hline
\end{tabular}

Immersed Test Electrodes vs. Room Temperature Laboratory-Grade Reference Electrodes

\begin{tabular}{|l|c|c|c|}
\hline & $\begin{array}{c}\text { Laboratory } \\
\text { Ag/AgCl }\end{array}$ & $\begin{array}{c}\text { Laboratory } \\
\text { Calomel }\end{array}$ & $\begin{array}{c}\text { Laboratory } \\
\text { Cu/CuSO }\end{array}$ \\
\hline AAR TC128 & -173.7 & -200.9 & -269.2 \\
\hline Cu Secondary & -298.3 & -326.8 & -395.2 \\
\hline Ni Secondary & -205.3 & -233.5 & -301.4 \\
\hline Ag Secondary & -123.3 & $-15 ! .9$ & -219.0 \\
\hline MPCMS Ag/AgCl & -9.4 & & \\
\hline MPCMS Calomel & & +9.7 & \\
\hline MPCMS Cu/CuSO & & & +3.4 \\
\hline
\end{tabular}

This page may be reproduced as necessary of 


\section{1-AN-107 Simulant}

Back of Electrodes Dry after Water

DATE: 216110 TIME: $8: 35 \mathrm{am}$ TEMP: $\frac{\begin{array}{c}(27.0) \\ 27.0\end{array}}{25.0} \mathrm{pH}: 10.63$

Immersed ASTM A537 and Secondary Electrodes vs.

Immersed MPCMS Reference Electrodes

\begin{tabular}{|l|l|l|l|}
\hline & $\begin{array}{c}\text { MPCMS } \\
\text { Ag/AgCl }\end{array}$ & $\begin{array}{c}\text { MPCMS } \\
\text { Calomel }\end{array}$ & $\begin{array}{c}\text { MPCMS } \\
\text { Cu/CuSO }\end{array}$ \\
\hline ASTM A537 & -229.6 & -374.1 & -43.7 \\
\hline Cu Secondary & -344.9 & -390.0 & -447.5 \\
\hline Ni Secondary & -217.0 & -261.4 & -319.1 \\
\hline Ag Secondary & -218.6 & -262.7 & -320.7 \\
\hline
\end{tabular}

Immersed Test Electrodes vs. Room Temperature MPCMS Reference Electrodes

\begin{tabular}{|l|l|l|l|l|}
\hline & $\begin{array}{c}\text { MPCMS } \\
\text { Ag/AgCl }\end{array}$ & $\begin{array}{c}\text { MPCMS } \\
\text { Calomel }\end{array}$ & $\begin{array}{c}\text { MPCMS } \\
\text { Cu/CuSO }_{4}\end{array}$ & $\begin{array}{c}\text { Electrode } \\
\text { Housing }\end{array}$ \\
\hline ASTM A537 & -337.5 & -379.6 & -450.3 & -203.6 \\
\hline Cu Secondary & -353.0 & -395.4 & -466.9 & -196.197 .0 \\
\hline Ni Secondary & -224.5 & -266.8 & -338.1 & -76.7 \\
\hline Ag Secondary & -225.6 & -267.6 & -338.8 & -75.0 \\
\hline MPCMS Ag/AgCl & -8.3 & & & +80.9 \\
\hline MPCMS Calomel & & -5.8 & & +144.8 \\
\hline MPCMS Cu/CuSO & & & -16.4 & +151.9 \\
\hline
\end{tabular}

Immersed Test Electrodes vs. Room Temperature Laboratory-Grade Reference Electrodes

\begin{tabular}{|l|c|c|c|}
\hline & $\begin{array}{c}\text { Laboratory } \\
\text { Ag/AgCl }\end{array}$ & $\begin{array}{c}\text { Laboratory } \\
\text { Calomel }\end{array}$ & $\begin{array}{c}\text { Laboratory } \\
\text { Cu/CuSO }\end{array}$ \\
\hline ASTM A537 & -350.4 & -378.5 & -446.4 \\
\hline Cu Secondary & -366.0 & -394.1 & -462.4 \\
\hline Ni Secondary & -237.2 & -265.5 & -333.3 \\
\hline Ag Secondary & -230.1 & -260.1 & -329.0 \\
\hline MPCMS Ag/AgCl & -20.3 & & \\
\hline MPCMS Calomel & & -4.6 & \\
\hline MPCMS Cu/CuSO & & & -11.5 \\
\hline
\end{tabular}

This page may be reproduced as necessary

C-3

Page 8 of 


\section{RPP-RPT-44463, Rev. 0 \\ RPP-PLAN-43916, Rev. 0}

\section{1-AY-101 Simulant}

\section{Wetted With Waste Simulant

DATE: 216110 TIME: $9: 45$ TEMP: 25.0 pH: 11.95

Immersed AAR TC128 and Secondary Electrodes vs. Immersed MPCMS Reference Electrodes

\begin{tabular}{|l|c|c|c|}
\hline & $\begin{array}{c}\text { MPCMS } \\
\text { Ag/AgCl }\end{array}$ & $\begin{array}{c}\text { MPCMS } \\
\text { Calomel }\end{array}$ & $\begin{array}{c}\text { MPCMS } \\
\text { Cu/CuSO }\end{array}$ \\
\hline AAR TC128 & -377.7 & -691.8 & -462.4 \\
\hline Cu Secondary & -224.8 & -540.1 & -311.5 \\
\hline Ni Secondary & -374.6 & -691.2 & -461.6 \\
\hline Ag Secondary & -347.3 & -663.7 & -733.
\end{tabular}$-434.0$

Immersed Test Electrodes vs. Room Temperature MPCMS Reference Electrodes

\begin{tabular}{|l|l|l|l|l|}
\hline & $\begin{array}{c}\text { MPCMS } \\
\mathbf{A g} / \mathbf{A g C l}\end{array}$ & $\begin{array}{c}\text { MPCMS } \\
\text { Calomel }\end{array}$ & $\begin{array}{c}\text { MPCMS } \\
\mathbf{C u} / \text { uSO }_{4}\end{array}$ & $\begin{array}{c}\text { Electrode } \\
\text { Housing }\end{array}$ \\
\hline AAR TC128 & -790.6 & -833.7 & -905.1 & -740.4 \\
\hline Cu Secondary & -639.2 & -6826 & -754.1 & -612.7 \\
\hline Ni Secondary & -788.6 & -832.4 & -903.8 & -721.5 \\
\hline Ag Secondary & -760.2 & -803.4 & -874.5 & -719.4 \\
\hline MPCMS Ag/AgCl & -411.2 & & & -393.1 \\
\hline MPCMS Calomel & & -136.5 & & -70.1 \\
\hline MPCMS Cu/CuSO & & & -432.6 & -57.7 \\
\hline
\end{tabular}

Immersed Test Electrodes vs. Room Temperature Laboratory-Grade Reference Electrodes

\begin{tabular}{|l|c|c|c|}
\hline & $\begin{array}{c}\text { Laboratory } \\
\text { Ag/AgCl }\end{array}$ & $\begin{array}{c}\text { Laboratory } \\
\text { Calomel }\end{array}$ & $\begin{array}{c}\text { Laboratory } \\
\text { Cu/CuSO}\end{array}$ \\
\hline AAR TC128 & -807.7 & -833.4 & -903.3 \\
\hline Cu Secondary & -652.1 & -682.7 & -752.6 \\
\hline Ni Secondary & -801.3 & -832.5 & -902.4 \\
\hline Ag Secondary & -770.9 & -801.2 & -870.3 \\
\hline MPCMS Ag/AgCl & -418.2 & & \\
\hline MPCMS Calomel & & -133.3 & \\
\hline MPCMS Cu/CuSO & & & -419.9 \\
\hline
\end{tabular}

This page may be reproduced as necessary of 
RPP-RPT-44463, Rev. 0

RPP-PLAN-43916, Rev. 0

\section{1-AN-107 Simulant}

\section{Wetted With Waste Simulant}

DATE: $216 / 10$ TIME: $9: 45$ TEMP: $\frac{26.9}{25.0}$ PH: 10.5

Immersed ASTM A537 and Secondary Electrodes vs. Immersed MPCMS Reference Electrodes

\begin{tabular}{|l|l|l|l|}
\hline & $\begin{array}{c}\text { MPCMS } \\
\text { Ag/AgCI }\end{array}$ & $\begin{array}{c}\text { MPCMS } \\
\text { Calomel }\end{array}$ & $\begin{array}{c}\text { MPCMS } \\
\text { Cu/CuSO }\end{array}$ \\
\hline ASTM A537 & -501.7 & -540.7 & -517.1 \\
\hline Cu Secondary & -371.8 & -411.65 & -388.7 \\
\hline Ni Secondary & -396.6 & -436.4 & -413.3 \\
\hline Ag Secondary & -415.2 & -455.0 & -431.7 \\
\hline
\end{tabular}

Immersed Test Electrodes vs. Room Temperature MPCMS Reference Electrodes

\begin{tabular}{|l|l|l|l|l|}
\hline & $\begin{array}{c}\text { MPCMS } \\
\text { Ag/AgCl }\end{array}$ & $\begin{array}{c}\text { MPCMS } \\
\text { Calomel }\end{array}$ & $\begin{array}{c}\text { MPCMS } \\
\text { Cu/CuSO }_{4}\end{array}$ & $\begin{array}{c}\text { Electrode } \\
\text { Housing }\end{array}$ \\
\hline ASTM A537 & -486.2 & -524.8 & -591.9 & -402.7 \\
\hline Cu Secondary & -364.5 & -404.6 & -472.6 & -370.2 \\
\hline Ni Secondary & -387.5 & -427.8 & -495.6 & -426.2 \\
\hline Ag Secondary & -404.9 & -445.0 & -512.5 & -378.4 \\
\hline MPCMS Ag/AgCl & -11.6 & & & 18.6 \\
\hline MPCMS Calomel & & -14.0 & & 36.3 \\
\hline MPCMS Cu/CuSO & & & -103.3 & -32.8 \\
\hline
\end{tabular}

Immersed Test Electrodes vs. Room Temperature Laboratory-Grade Reference Electrodes

\begin{tabular}{|l|c|c|c|}
\hline & $\begin{array}{c}\text { Laboratory } \\
\text { Ag/AgCl }\end{array}$ & $\begin{array}{c}\text { Laboratory } \\
\text { Calomel }\end{array}$ & $\begin{array}{c}\text { Laboratory } \\
\text { Cu/CuSO }\end{array}$ \\
\hline ASTM A537 & -495.0 & -521.2 & -587.1 \\
\hline Cu Secondary & -375.8 & -402.9 & -469.0 \\
\hline Ni Secondary & -398.6 & -425.7 & -491.8 \\
\hline Ag Secondary & -415.1 & -442.7 & -508.6 \\
\hline MPCMS Ag/AgCI & -22.0 & & \\
\hline MPCMS Calomel & & -12.7 & \\
\hline MPCMS Cu/CuSO4 & & & -99.5 \\
\hline
\end{tabular}

This page may be reproduced as necessary

C-7

Page 10

of 
RPP-RPT-44463, Rev. 0

RPP-PLAN-43916, Rev. 0

241-AY-101 Simulant

Back of Electrodes Dry after waste

DATE: $\frac{112 \mathrm{\alpha}}{216 / 11}$ TIME: $11: 25 \mathrm{am}$ TEMP: 216110 TIME: $11.25 \mathrm{am}$ TEMP:

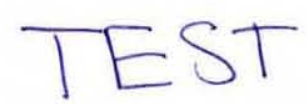

Housing only

taken immediately ofter installing into test pH:

well

Immersed AAR TC128 and Secondary Electrodes vs.

Immersed MPCMS Reference Electrodes

\begin{tabular}{|l|c|c|c|}
\hline & $\begin{array}{c}\text { MPCMS } \\
\text { Ag/AgCl }\end{array}$ & $\begin{array}{c}\text { MPCMS } \\
\text { Calomel }\end{array}$ & $\begin{array}{c}\text { MPCMS } \\
\text { Cu/CuSO }\end{array}$ \\
\hline AAR TC128 & & & \\
\hline Cu Secondary & & & \\
\hline Ni Secondary & & & \\
\hline Ag Secondary & & & \\
\hline
\end{tabular}

Immersed Test Electrodes vs. Room Temperature MPCMS Reference Electrodes

\begin{tabular}{|l|l|l|l|l|}
\hline & $\begin{array}{c}\text { MPCMS } \\
\text { Ag/AgCI }\end{array}$ & $\begin{array}{c}\text { MPCMS } \\
\text { Calomel }\end{array}$ & $\begin{array}{c}\text { MPCMS } \\
\text { Cu/CuSO }\end{array}$ & $\begin{array}{c}\text { Electrode } \\
\text { Housing }\end{array}$ \\
\hline AAR TC128 & & & & -185.7 \\
\hline Cu Secondary & & & -61.9 \\
\hline Ni Secondary & & & -149.4 \\
\hline Ag Secondary & & & & -32.7 \\
\hline MPCMS Ag/AgCl & & & & -68.0 \\
\hline MPCMS Calomel & & & & +108.7 \\
\hline MPCMS Cu/CuSO & & & & +208.0 \\
\hline
\end{tabular}

Immersed Test Electrodes vs. Room Temperature Laboratory-Grade Reference Electrodes

\begin{tabular}{|l|l|l|l|}
\hline & $\begin{array}{c}\text { Laboratory } \\
\text { Ag/AgCl }\end{array}$ & $\begin{array}{c}\text { Laboratory } \\
\text { Calomel }\end{array}$ & $\begin{array}{c}\text { Laboratory } \\
\text { Cu/CuSO }\end{array}$ \\
\hline AAR TC128 & & & \\
\hline Cu Secondary & & & \\
\hline Ni Secondary & & & \\
\hline Ag Secondary & & & \\
\hline MPCMS Ag/AgCl & & & \\
\hline MPCMS Calomel & & & \\
\hline MPCMS Cu/CuSO & & & \\
\hline
\end{tabular}

This page may be reproduced as necessary

C-2

Page $\mid 1$

of 
RPP-RPT-44463, Rev. 0

\section{1-AN-107 Simulant}

Back of Electrodes Dry after Wuste

\section{TEST}

Housing

DATE: 216110 TIME: $11: 25 \mathrm{am}$ TEMP:

pH:

Immersed ASTM A537 and Secondary Electrodes vs.

Immersed MPCMS Reference Electrodes

\begin{tabular}{|l|c|c|c|}
\hline & $\begin{array}{c}\text { MPCMS } \\
\text { Ag/AgCl }\end{array}$ & $\begin{array}{c}\text { MPCMS } \\
\text { Calomel }\end{array}$ & $\begin{array}{c}\text { MPCMS } \\
\mathrm{Cu}^{\text {/CuSO }}\end{array}$ \\
\hline ASTM A537 & & & \\
\hline Cu Secondary & & & \\
\hline Ni Secondary & & & \\
\hline Ag Secondary & & & \\
\hline
\end{tabular}

Immersed Test Electrodes vs. Room Temperature MPCMS Reference Electrodes

\begin{tabular}{|l|l|l|l|l|}
\hline & $\begin{array}{c}\text { MPCMS } \\
\text { Ag/AgCl }\end{array}$ & $\begin{array}{c}\text { MPCMS } \\
\text { Calomel }\end{array}$ & $\begin{array}{c}\text { MPCMS } \\
\text { Cu/CuSO }\end{array}$ & $\begin{array}{c}\text { Electrode } \\
\text { Housing }\end{array}$ \\
\hline ASTM A537 & & & & -195.0 \\
\hline Cu Secondary & & & & -127.2 \\
\hline Ni Secondary & & & & -161.1 \\
\hline Ag Secondary & & & & -91.3 \\
\hline MPCMS Ag/AgCl & & & & +49.0 \\
\hline MPCMS Calomel & & & & +158.2 \\
\hline MPCMS Cu/CuSO & & & & +41.8 \\
\hline
\end{tabular}

Immersed Test Electrodes vs. Room Temperature Laboratory-Grade Reference Electrodes

\begin{tabular}{|l|l|l|l|}
\hline & $\begin{array}{c}\text { Laboratory } \\
\text { Ag/AgCl }\end{array}$ & $\begin{array}{c}\text { Laboratory } \\
\text { Calomel }\end{array}$ & $\begin{array}{c}\text { Laboratory } \\
\text { Cu/CuSO }\end{array}$ \\
\hline ASTM A537 & & & \\
\hline Cu Secondary & & & \\
\hline Ni Secondary & & & \\
\hline Ag Secondary & & & \\
\hline MPCMS Ag/AgCl & & & \\
\hline MPCMS Calomel & & & \\
\hline MPCMS Cu/CuSO & & & \\
\hline
\end{tabular}

This page may be reproduced as necessary

C-3

Page $1 \gamma$ of 
RPP-RPT-44463, Rev. 0

RPP-PLAN-43916, Rev. 0

\section{1-AY-101 Simulant}

Back of Electrodes Dry after Wa Ste

DATE: $\frac{216110}{4: 15 \mathrm{pm}}$ TIME: $\frac{12 \div 10 \mathrm{pm} \text { TEMP: }}{40}$

(27.0)

$\frac{26.9}{25.0} \mathrm{pH}: \frac{12.12}{2}$

Immersed AAR TC128 and Secondary Electrodes vs.

Immersed MPCMS Reference Electrodes

\begin{tabular}{|l|l|l|l|}
\hline & $\begin{array}{c}\text { MPCMS } \\
\text { Ag/AgCl }\end{array}$ & $\begin{array}{c}\text { MPCMS } \\
\text { Calomel }\end{array}$ & \multicolumn{1}{|c|}{$\begin{array}{c}\text { MPCMS } \\
\mathrm{Cu}^{\text {CCuSO }}\end{array}$} \\
\hline AAR TC128 & -383.1 & -437.7 & -509.1 \\
\hline Cu Secondary & -263.2 & -318.1 & -389.4 \\
\hline Ni Secondary & -273.5 & -329.6 & -400.1 \\
\hline Ag Secondary & -135.6 & -190.5 & -261.5 \\
\hline
\end{tabular}

Immersed Test Electrodes vs. Room Temperature MPCMS Reference Ellectrodes

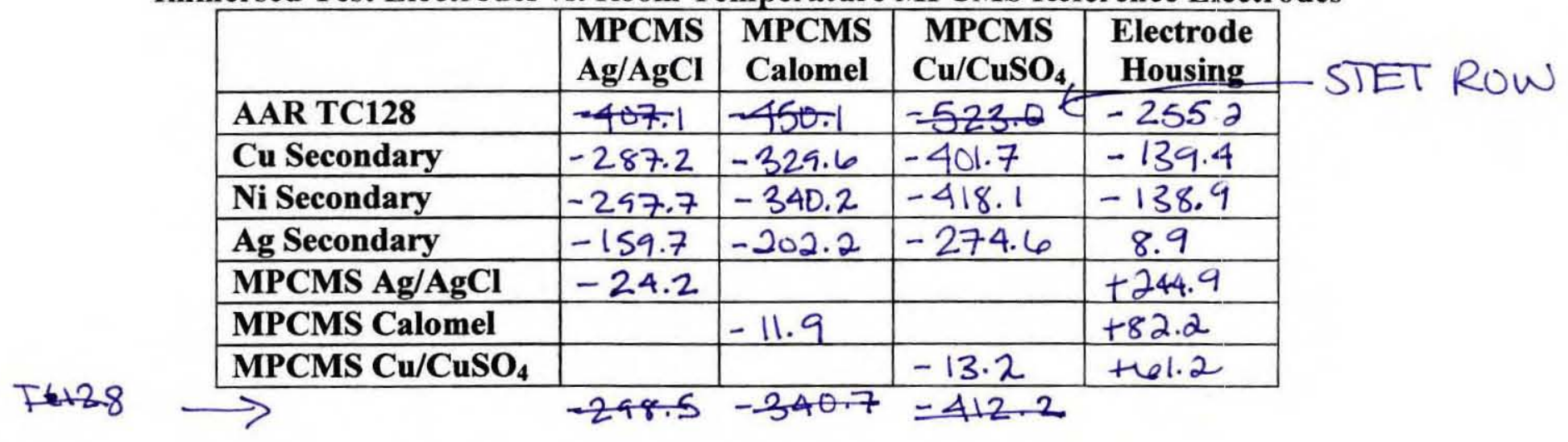

Immersed Test Electrodes vs. Room Temperature Laboratory-Grade Reference Electrodes

\begin{tabular}{|l|l|l|l|}
\hline & $\begin{array}{c}\text { Laboratory } \\
\text { Ag/AgCl }\end{array}$ & $\begin{array}{c}\text { Laboratory } \\
\text { Calomel }\end{array}$ & $\begin{array}{c}\text { Laboratory } \\
\text { Cu/CuSO }\end{array}$ \\
\hline AAR TC128 & -421.5 & -450.4 & -519.5 \\
\hline Cu Secondary & $-26-300.0$ & -328.1 & -396.9 \\
\hline Ni Secondary & -319.3 & -350.7 & -420.9 \\
\hline Ag Secondary & -172.2 & -201.3 & -270.1 \\
\hline MPCMS Ag/AgCl & -36.7 & & \\
\hline MPCMS Calomel & & -10.7 & \\
\hline MPCMS Cu/CuSO & & & -7.8 \\
\hline
\end{tabular}

This page may be reproduced as necessary

C-2

Page 13

of 
241-AN-107 Simulant

Back of Electrodes Dry after Waste (27.0)

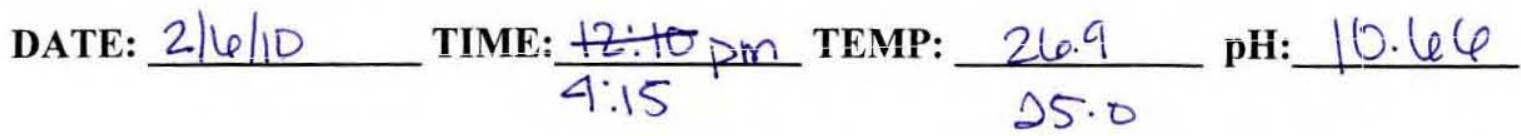

Immersed ASTM A537 and Secondary Electrodes vs.

Immersed MPCMS Reference Electrodes

\begin{tabular}{|l|c|c|c|}
\hline & $\begin{array}{c}\text { MPCMS } \\
\text { Ag/AgCl }\end{array}$ & $\begin{array}{c}\text { MPCMS } \\
\text { Calomel }\end{array}$ & $\begin{array}{c}\text { MPCMS } \\
\text { Cu/CuSO }\end{array}$ \\
\hline ASTM A537 & -288.2 & -334.8 & -372.3 \\
\hline Cu Secondary & -357.8 & -404.9 & -441.8 \\
\hline Ni Secondary & -199.8 & -246.6 & -284.4 \\
\hline Ag Secondary & -290.3 & -337.2 & -874.3 \\
\hline
\end{tabular}

Immersed Test Electrodes vs. Room Temperature MPCMS Reference Electrodes

\begin{tabular}{|l|l|l|l|l|}
\hline & $\begin{array}{c}\text { MPCMS } \\
\text { Ag/AgCl }\end{array}$ & $\begin{array}{c}\text { MPCMS } \\
\text { Calomel }\end{array}$ & $\begin{array}{c}\text { MPCMS } \\
\text { Cu/CuSO }\end{array}$ & $\begin{array}{c}\text { Electrode } \\
\text { Housing }\end{array}$ \\
\hline ASTM A537 & -298.8 & -341.0 & -412.9 & -142.6 \\
\hline Cu Secondary & -367.9 & -410.3 & -482.2 & -282.0 \\
\hline Ni Secondary & -210.7 & -253.0 & -325.1 & -88.2 \\
\hline Ag Secondary & -300.4 & -342.8 & -414.7 & -158.9 \\
\hline MPCMS Ag/AgCl & $-\# 12.0$ & & & -207.2 \\
\hline MPCMS Calomel & & -7.6 & & -109.6 \\
\hline MPCMS Cu/CuSO & & & -40.1 & 3.3 \\
\hline
\end{tabular}

Immersed Test Electrodes vs. Room Temperature Laboratory-Grade Reference Electrodes

\begin{tabular}{|l|l|l|l|}
\hline & $\begin{array}{c}\text { Laboratory } \\
\text { Ag/AgCl }\end{array}$ & $\begin{array}{c}\text { Laboratory } \\
\text { Calomel }\end{array}$ & $\begin{array}{c}\text { Laboratory } \\
\text { Cu/CuSO }\end{array}$ \\
\hline ASTM A537 & -311.6 & -339.7 & -408.8 \\
\hline Cu Secondary & -380.6 & -409.3 & -478.3 \\
\hline Ni Secondary & -223.2 & -252.0 & -321.0 \\
\hline Ag Secondary & -312.8 & -341.4 & -410.4 \\
\hline MPCMS Ag/AgCl & -24.4 & & \\
\hline MPCMS Calomel & & -6.3 & \\
\hline MPCMS Cu/CuSO & & & -35.3 \\
\hline
\end{tabular}

This page may be reproduced as necessary

C-3

Page 14

of 


$$
\begin{aligned}
& \text { RPP-RPT-44463, Rev. } 0 \\
& \text { RPP-PLAN-43916, Rev. } 0
\end{aligned}
$$

\section{1-AY-101 Simulant}

\section{Wetted With Foam Component Liquid}

DATE: $2 / 6110$ TIME: $4: 45$ pm TEMP: $\frac{}{25.0}$ pH: 11.60

Immersed AAR TC128 and Secondary Electrodes vs.

Immersed MPCMS Reference Electrodes

\begin{tabular}{|l|l|l|l|}
\hline & $\begin{array}{l}\text { MPCMS } \\
\text { Ag/AgCI }\end{array}$ & $\begin{array}{l}\text { MPCMS } \\
\text { Calomel }\end{array}$ & $\begin{array}{l}\text { MPCMS } \\
\text { Cu/CuSO }\end{array}$ \\
\hline AAR TC128 & -407.5 & -3034.0 & -513.7 \\
\hline Cu Secondary & -276.2 & -324.7 & -382.6 \\
\hline Ni Secondary & -472.4 & -522.7 & -584.2 \\
\hline Ag Secondary & -197.7 & -248.3 & -299.4 \\
\hline
\end{tabular}

Immersed Test Electrodes vs. Room Temperature MPCMS Reference Electrodes

\begin{tabular}{|l|c|l|l|l|}
\hline & $\begin{array}{l}\text { MPCMS } \\
\text { Ag/AgCl }\end{array}$ & $\begin{array}{l}\text { MPCMS } \\
\text { Calomel }\end{array}$ & $\begin{array}{l}\text { MPCMS } \\
\text { Cu/CuSO }\end{array}$ & $\begin{array}{l}\text { Electrode } \\
\text { Housing }\end{array}$ \\
\hline AAR TC128 & -414.7 & -456.9 & -525.3 & -255.5 \\
\hline Cu Secondary & -284.9 & -328.2 & -400.5 & -133.7 \\
\hline Ni Secondary & -474.6 & -504.0 & -587.9 & -316.2 \\
\hline Ag Secondary & -201.4 & -330.4 & -317.2 & -44.9 \\
\hline MPCMS Ag/AgCl & -3.0 & & & +115.2 \\
\hline MPCMS Calomel & & $t 2.5$ & & +176.5 \\
\hline MPCMS Cu/CuSO & & & -16.7 & -224.3 \\
\hline
\end{tabular}

Immersed Test Electrodes vs. Room Temperature Laboratory-Grade Reference Electrodes

\begin{tabular}{|l|l|l|l|}
\hline & $\begin{array}{l}\text { Laboratory } \\
\text { Ag/AgCl }\end{array}$ & $\begin{array}{l}\text { Laboratory } \\
\text { Calomel }\end{array}$ & $\begin{array}{l}\text { Laboratory } \\
\text { Cu/CuSO}\end{array}$ \\
\hline AAR TC128 & -4250 & -452.9 & -520.6 \\
\hline Cu Secondary & -257.2 & -326.9 & -395.3 \\
\hline Ni Secondary & -484.5 & -2512.8 & -580.1 \\
\hline Ag Secondary & -214.2 & -243.2 & -311.4 \\
\hline MPCMS Ag/AgCl & -14.8 & & \\
\hline MPCMS Calomel & & +3.8 & \\
\hline MPCMS Cu/CuSO & & & -10.1 \\
\hline
\end{tabular}

This page may be reproduced as necessary 
241-AN-107 Simulant

\section{Wetted With Foam Component Liquid}
DATE: 216110
TIME: $4: 45 \mathrm{pm}$
TEMP:
$\mathrm{pH}: 10.58$
25.0

Immersed ASTM A537 and Secondary Electrodes vs. Immersed MPCMS Reference Electrodes

\begin{tabular}{|l|l|l|l|}
\hline & $\begin{array}{c}\text { MPCMS } \\
\text { Ag/AgCl }\end{array}$ & $\begin{array}{c}\text { MPCMS } \\
\text { Calomel }\end{array}$ & $\begin{array}{c}\text { MPCMS } \\
\text { Cu/CuSO }\end{array}$ \\
\hline ASTM A537 & -370.0 & -414.6 & -398.6 \\
\hline Cu Secondary & -368.6 & -413.3 & -397.0 \\
\hline Ni Secondary & -268.5 & -313.0 & -297.0 \\
\hline Ag Secondary & -356.4 & $-406,-385.0$ \\
\hline
\end{tabular}

Immersed Test Electrodes vs. Room Temperature MPCMS Reference Electrodes

\begin{tabular}{|c|c|c|c|c|c|}
\hline & $\begin{array}{l}\text { MPCMS } \\
\text { Ag/AgCl }\end{array}$ & $\begin{array}{l}\text { MPCMS } \\
\text { Calomel }\end{array}$ & $\begin{array}{c}\text { MPCMS } \\
{\mathrm{Cu} / \mathrm{CuSO}_{4}}^{4}\end{array}$ & $\begin{array}{l}\text { Electrode } \\
\text { Housing }\end{array}$ & \\
\hline ASTM A537 & $75^{-3}-3.00$ & -423.8 & -496.0 & -395.91 & -231.5 \\
\hline Cu Secondary & -378.4 & -421.1 & -493.0 & -390.3 & $\frac{*}{2}-297.7$ \\
\hline Ni Secondary & -278.8 & -321.5 & -393.5 & \multicolumn{2}{|c|}{$-290:-291.0-161.1$} \\
\hline Ag Secondary & -367.8 & -410.4 & -482.6 & -380.3 & -240.3 \\
\hline MPCMS Ag/AgCl & -11.1 & & & +52.0 & \\
\hline MPCMS Calomel & & -9.4 & & +5.7 & \\
\hline${\mathrm{MPCMS} \mathrm{Cu} / \mathrm{CuSO}_{4}}_{4}$ & & & -95.8 & +36.7 & \\
\hline
\end{tabular}

Immersed Test Electrodes vs. Room Temperature Laboratory-Grade Reference Electrodes

\begin{tabular}{|l|l|l|l|}
\hline & $\begin{array}{c}\text { Laboratory } \\
\text { Ag/AgCl }\end{array}$ & $\begin{array}{c}\text { Laboratory } \\
\text { Calomel }\end{array}$ & $\begin{array}{c}\text { Laboratory } \\
\text { Cu/CuSO }\end{array}$ \\
\hline ASTM A537 & -395.1 & -424.1 & -490.8 \\
\hline Cu Secondary & -390.3 & -419.5 & -488.1 \\
\hline Ni Secondary & -291.0 & -320.2 & -388.9 \\
\hline Ag Secondary & -380.3 & -410.6 & -479.0 \\
\hline MPCMS Ag/AgCl & -22.6 & & \\
\hline MPCMS Calomel & & -8.1 & \\
\hline MPCMS Cu/CuSO & & & -90.3 \\
\hline
\end{tabular}

This page may be reproduced as necessary

Page +45 of 


\section{1-AY-101 Simulant}

Electrolyte Contamination - DRe Contamination

DATE: TIME:

Amount of Contaminant Added (Total):

TEMP:

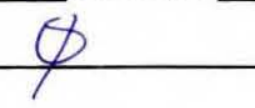
25.0

$\mathrm{pH}: 12.12$

Immersed AAR TC128 Electrode vs. Immersed MPCMS Reference Electrodes

\begin{tabular}{|l|l|l|l|}
\hline & $\begin{array}{l}\text { MPCMS } \\
\text { Ag/AgCl }\end{array}$ & $\begin{array}{l}\text { MPCMS } \\
\text { Calomel }\end{array}$ & $\begin{array}{l}\text { MPCMS } \\
\text { Cu/CuSO }_{4}\end{array}$ \\
\hline AAR TC128 & -331.0 & -371.4 & -230.3 \\
$x$ & -547.0
\end{tabular}

Immersed Test Electrodes vs. Room Temperature MPCMS Reference Electrodes

\begin{tabular}{|l|l|l|l|}
\hline & $\begin{array}{l}\text { MPCMS } \\
\text { Ag/AgCl }\end{array}$ & $\begin{array}{l}\text { MPCMS } \\
\text { Calomel }\end{array}$ & $\begin{array}{l}\text { MPCMS } \\
\text { Cu/CuSO }\end{array}$ \\
\hline AAR TC128 & -304.7 & -345.5 & -416.7 \\
\hline MPCMS Ag/AgCl & +7.9 & & \\
\hline MPCMS Calomel & & +8.0 & \\
\hline MPCMS Cu/CuSO & & & +6.0 \\
\hline
\end{tabular}

Immersed Test Electrodes vs. Room Temperature Laboratory-Grade Reference Electrodes

\begin{tabular}{|l|l|l|l|}
\hline & $\begin{array}{l}\text { Laboratory } \\
\text { Ag/AgCl }\end{array}$ & $\begin{array}{l}\text { Laboratory } \\
\text { Calomel }\end{array}$ & $\begin{array}{l}\text { Laboratory } \\
\text { Cu/CuSO}_{4}\end{array}$ \\
\hline AAR TC128 & -314.2 & -340.3 & -403.4 \\
\hline MPCMS Ag/AgCl & -5.4 & & \\
\hline MPCMS Calomel & & +9.2 & \\
\hline MPCMS Cu/CuSO & & & +16.6 \\
\hline
\end{tabular}

* $\mathrm{Cu} / \mathrm{CuSO}_{4}$ Electrode replaced w/ replacement $\mathrm{Cu} \mathrm{KuSO}_{4}$ Electrode. Old electrode wire was beoken duking lep remwal.

This page may be reproduced as necessary.

C-10

Page 16

of 


\section{1-AN-107 Simulant}

Electrolyte Contamination - PRe-Centamination

DATE: $2 / 7110$
Amount of Contaminant Added (Total): $\varnothing$

Immersed ASTM A537 Electrode vs. Immersed MPCMS Reference Electrodes

\begin{tabular}{|l|c|c|c|}
\hline & $\begin{array}{c}\text { MPCMS } \\
\text { Ag/AgCl }\end{array}$ & $\begin{array}{c}\text { MPCMS } \\
\text { Calomel }\end{array}$ & $\begin{array}{c}\text { MPCMS } \\
\mathbf{C u} / \mathbf{C u S O}_{4}\end{array}$ \\
\hline ASTM A537 & -339.2 & -384.3 & -454.5 \\
\hline
\end{tabular}

Immersed Test Electrodes vs. Room Temperature MPCMS Reference Electrodes

\begin{tabular}{|l|l|l|l|}
\hline & $\begin{array}{l}\text { MPCMS } \\
\text { Ag/AgCl }\end{array}$ & $\begin{array}{c}\text { MPCMS } \\
\text { Calomel }\end{array}$ & $\begin{array}{c}\text { MPCMS } \\
\text { Cu/CuSO }\end{array}$ \\
\hline ASTM A537 & -3523 & -397.3 & -471.1 \\
\hline MPCMS Ag/AgCl & -7.3 & & \\
\hline MPCMS Calomel & & -4.8 & \\
\hline MPCMS Cu/CuSO & & & -7.3 \\
\hline
\end{tabular}

Immersed Test Electrodes vs. Room Temperature Laboratory-Grade Reference Electrodes

\begin{tabular}{|l|c|c|c|}
\hline & $\begin{array}{c}\text { Laboratory } \\
\text { Ag/AgCl }\end{array}$ & $\begin{array}{c}\text { Laboratory } \\
\text { Calomel }\end{array}$ & $\begin{array}{c}\text { Laboratory } \\
\text { Cu/CuSO }\end{array}$ \\
\hline ASTM A537 & -370.8 & -399.6 & -464.6 \\
\hline MPCMS Ag/AgCl & -21.0 & & \\
\hline MPCMS Calomel & & -3.8 & \\
\hline MPCMS Cu/CuSO & & & +2.8 \\
\hline
\end{tabular}

This page may be reproduced as necessary.

B-11

Page 17 of 


$$
\begin{aligned}
& \text { RPP-RPT-44463, Rev. } 0 \\
& \text { RPP-PLAN-43916, Rev. } 0
\end{aligned}
$$

241-AY-101 Simulant

\section{Electrolyte Contamination}

DATE: $2 / 7 / 10$ TIME: $12: 05$

Amount of Contaminant Added (Total): .2mL

$$
(25.1)
$$

TEMP: $\quad 25-1$ 25.0

pH: 12.07

Immersed AAR TC128 Electrode vs. Immersed MPCMS Reference Electrodes

\begin{tabular}{|l|l|l|l|}
\hline & $\begin{array}{l}\text { MPCMS } \\
\text { Ag/AgCl }\end{array}$ & $\begin{array}{l}\text { MPCMS } \\
\text { Calomel }\end{array}$ & $\begin{array}{l}\text { MPCMS } \\
\text { Cu/CuSO }\end{array}$ \\
\hline AAR TC128 & -712.2 & -788.9 & -653.2 \\
\hline
\end{tabular}

Immersed Test Electrodes vs. Room Temperature MPCMS Reference Electrodes

\begin{tabular}{|c|c|c|c|}
\hline & $\begin{array}{l}\text { Laboratory } \\
\text { Ag/AgCl }\end{array}$ & $\begin{array}{l}\text { Laboratory } \\
\text { Calomel }\end{array}$ & $\begin{array}{l}\text { Laboratory } \\
\mathrm{Cu} / \mathrm{CuSO}_{4}\end{array}$ \\
\hline AAR TC128 & -742.6 & -770.9 & -838.2 \\
\hline MPCMS Ag/AgCl & -40.5 & & \\
\hline MPCMS Calomel & & +8.6 & \\
\hline${\mathrm{MPCMS} \mathrm{Cu} / \mathrm{CuSO}_{4}}$ & & & -178.0 \\
\hline
\end{tabular}

\begin{tabular}{|l|l|l|l|}
\hline & $\begin{array}{l}\text { MPCMS } \\
\text { Ag/AgCl }\end{array}$ & $\begin{array}{l}\text { MPCMS } \\
\text { Calomel }\end{array}$ & $\begin{array}{l}\text { MPCMS } \\
\text { Cu/CuSO }\end{array}$ \\
\hline AAR TC128 & -718.7 & -760.0 & -835.5 \\
\hline MPCMS Ag/AgCl & -29.6 & & \\
\hline MPCMS Calomel & & +7.3 & \\
\hline MPCMS Cu/CuSO & & & -189.0 \\
\hline
\end{tabular}

Immersed Test Electrodes vs. Room Temperature Laboratory-Grade Reference Electrodes

This page may be reproduced as necessary. of 


\section{1-AN-107 Simulant}

\section{Electrolyte Contamination}

DATE: $\frac{\partial / 7 / 10}{\text { Amount of Contaminant Added (Total): } ـ .2 \mathrm{~mL}}=\frac{25.1}{25.0} \mathrm{pH}: 10.55$

Immersed ASTM A537 Electrode vs. Immersed MPCMS Reference Electrodes

\begin{tabular}{|l|c|c|c|}
\hline & $\begin{array}{c}\text { MPCMS } \\
\text { Ag/AgCl }\end{array}$ & $\begin{array}{c}\text { MPCMS } \\
\text { Calomel }\end{array}$ & $\begin{array}{c}\text { MPCMS } \\
\mathbf{C u}^{\text {CuSO }} \text { 4 }\end{array}$ \\
\hline ASTM A537 & -389.1 & -430.8 & -466.9 \\
\hline
\end{tabular}

Immersed Test Electrodes vs. Room Temperature MPCMS Reference Electrodes

\begin{tabular}{|l|l|l|l|}
\hline & $\begin{array}{c}\text { MPCMS } \\
\text { Ag/AgCl }\end{array}$ & $\begin{array}{c}\text { MPCMS } \\
\text { Calomel }\end{array}$ & $\begin{array}{c}\text { MPCMS } \\
\text { Cu/CuSO }\end{array}$ \\
\hline ASTM A537 & -896.6 & -440.9 & -514.5 \\
\hline MPCMS Ag/AgCl & -6.0 & & \\
\hline MPCMS Calomel & & -7.3 & \\
\hline MPCMS Cu/CuSO & & & -44.4 \\
\hline
\end{tabular}

Immersed Test Electrodes vs. Room Temperature Laboratory-Grade Reference Electrodes

\begin{tabular}{|l|l|l|l|}
\hline & $\begin{array}{c}\text { Laboratory } \\
\text { Ag/AgCl }\end{array}$ & $\begin{array}{c}\text { Laboratory } \\
\text { Calomel }\end{array}$ & $\begin{array}{c}\text { Laboratory } \\
\text { Cu/CuSO }\end{array}$ \\
\hline ASTM A537 & -413.8 & -442.9 & -509.1 \\
\hline MPCMS Ag/AgCl & -18.9 & & \\
\hline MPCMS Calomel & & -6.0 & \\
\hline MPCMS Cu/CuSO & & & -36.0 \\
\hline
\end{tabular}

This page may be reproduced as necessary. of 


$$
\begin{aligned}
& \text { RPP-RPT-44463, Rev. } 0 \\
& \text { RPP-PLAN-43916, Rev. } 0
\end{aligned}
$$

241-AY-101 Simulant

\section{Electrolyte Contamination}

DATE: 217110 TIME: $12: 35$ TEMP: 24.1 $\mathrm{pH}: \quad 12.07$

Amount of Contaminant Added (Total): $0.5 \mathrm{~mL}$

Immersed AAR TC128 Electrode vs. Immersed MPCMS Reference Electrodes

\begin{tabular}{|l|l|l|l|}
\hline & $\begin{array}{l}\text { MPCMS } \\
\mathbf{A g} / \mathbf{A g C l}\end{array}$ & $\begin{array}{l}\text { MPCMS } \\
\text { Calomel }\end{array}$ & $\begin{array}{l}\text { MPCMS } \\
\mathbf{C u}_{\mathbf{C u S O}}\end{array}$ \\
\hline AAR TC128 & -563.8 & -599.5 & -658.4 \\
\hline
\end{tabular}

Immersed Test Electrodes vs. Room Temperature MPCMS Reference Electrodes

\begin{tabular}{|l|l|l|l|}
\hline & $\begin{array}{l}\text { MPCMS } \\
\text { Ag/AgCl }\end{array}$ & $\begin{array}{l}\text { MPCMS } \\
\text { Calomel }\end{array}$ & $\begin{array}{l}\text { MPCMS } \\
\text { Cu/CuSO }_{4}\end{array}$ \\
\hline AAR TC128 & -545.9 & -587.0 & -660.8 \\
\hline MPCMS Ag/AgCl & +14.4 & & \\
\hline MPCMS Calomel & & +8.2 & \\
\hline MPCMS Cu/CuSO & & & -5.0 \\
\hline
\end{tabular}

Immersed Test Electrodes vs. Room Temperature Laboratory-Grade Reference Electrodes

\begin{tabular}{|l|l|l|l|}
\hline & $\begin{array}{l}\text { Laboratory } \\
\text { Ag/AgCl }\end{array}$ & $\begin{array}{l}\text { Laboratory } \\
\text { Calomel }\end{array}$ & $\begin{array}{l}\text { Laboratory } \\
\text { Cu/CuSO}\end{array}$ \\
\hline AAR TC128 & -557.7 & -585.8 & -653.0 \\
\hline MPCMS Ag/AgCl & +1.8 & & \\
\hline MPCMS Calomel & & +9.4 & \\
\hline MPCMS Cu/CuSO & & & +2.3 \\
\hline
\end{tabular}

This page may be reproduced as necessary. of 


\section{1-AN-107 Simulant}

\section{Electrolyte Contamination

DATE: 21710 TIME: $12: 35$ TEMP: 24.4 pH: 10.6 Amount of Contaminant Added (Total): $0.5 \mathrm{~mL}$

Immersed ASTM A537 Electrode vs. Immersed MPCMS Reference Ellectrodes

\begin{tabular}{|l|c|c|c|}
\hline & $\begin{array}{c}\text { MPCMS } \\
\text { Ag/AgCl }\end{array}$ & $\begin{array}{c}\text { MPCMS } \\
\text { Calomel }\end{array}$ & $\begin{array}{c}\text { MPCMS } \\
\mathbf{C u} / \mathbf{C u S O}_{4}\end{array}$ \\
\hline ASTM A537 & -382.7 & -420.8 & -456.3 \\
\hline
\end{tabular}

Immersed Test Electrodes vs. Room Temperature MPCMS Reference Electrodes

\begin{tabular}{|l|l|l|l|}
\hline & $\begin{array}{c}\text { MPCMS } \\
\text { Ag/AgCl }\end{array}$ & $\begin{array}{c}\text { MPCMS } \\
\text { Calomel }\end{array}$ & $\begin{array}{c}\text { MPCMS } \\
\text { Cu/CuSO }\end{array}$ \\
\hline ASTM A537 & -385.1 & -427.8 & -500.1 \\
\hline MPCMS Ag/AgCl & -3.0 & & \\
\hline MPCMS Calomel & & -7.5 & \\
\hline MPCMS Cu/CuSO & & & -44.1 \\
\hline
\end{tabular}

Immersed Test Electrodes vs. Room Temperature Laboratory-Grade Reference Electrodes

\begin{tabular}{|l|l|l|l|}
\hline & $\begin{array}{c}\text { Laboratory } \\
\text { Ag/AgCl }\end{array}$ & $\begin{array}{c}\text { Laboratory } \\
\text { Calomel }\end{array}$ & $\begin{array}{c}\text { Laboratory } \\
\text { Cu/CuSO }\end{array}$ \\
\hline ASTM A537 & -397.9 & -426.3 & -493.7 \\
\hline MPCMS Ag/AgCl & -15.5 & & \\
\hline MPCMS Calomel & & -6.2 & \\
\hline MPCMS Cu/CuSO & & & -36.7 \\
\hline
\end{tabular}

This page may be reproduced as necessary. of 


$$
\begin{aligned}
& \text { RPP-RPT-44463, Rev. } 0 \\
& \text { RPP-PLAN-43916, Rev. } 0
\end{aligned}
$$

$A y-101$

241-AN-107 Simulant

Electrolyte Contamination

DATE: 21710 TIME: $1: 15 \mathrm{pm}$ TEMP: 24.5 pH: 12.03 Amount of Contaminant Added (Total): Complete full 25.4 waste

Immersed ASTM A537 Electrode vs. Immersed MPCMS Reference Ellectrodes

\begin{tabular}{|l|c|c|c|}
\hline & $\begin{array}{c}\text { MPCMS } \\
\text { Ag/AgCl }\end{array}$ & $\begin{array}{c}\text { MPCMS } \\
\text { Calomel }\end{array}$ & $\begin{array}{c}\text { MPCMS } \\
\mathbf{C u}^{\text {CuSO }} \text { 4 }\end{array}$ \\
\hline ASTM A537 & -649.2 & -711.7 & -675.9 \\
\hline
\end{tabular}

Immersed Test Electrodes vs. Room Temperature MPCMS Reference Electrodes

\begin{tabular}{|l|l|l|l|}
\hline & $\begin{array}{c}\text { MPCMS } \\
\text { Ag/AgCl }\end{array}$ & $\begin{array}{c}\text { MPCMS } \\
\text { Calomel }\end{array}$ & $\begin{array}{c}\text { MPCMS } \\
\text { Cu/CuSO }\end{array}$ \\
\hline ASTM A537 & -666.0 & -707.0 & -778.7 \\
\hline MPCMS Ag/AgCl & -18.7 & & \\
\hline MPCMS Calomel & & +1.2 & \\
\hline MPCMS Cu/CuSO & & & -110.9 \\
\hline
\end{tabular}

Immersed Test Electrodes vs. Room Temperature Laboratory-Grade Reference Electrodes

\begin{tabular}{|l|c|c|c|}
\hline & $\begin{array}{c}\text { Laboratory } \\
\text { Ag/AgCl }\end{array}$ & $\begin{array}{c}\text { Laboratory } \\
\text { Calomel }\end{array}$ & $\begin{array}{c}\text { Laboratory } \\
\text { Cu/CuSO }\end{array}$ \\
\hline ASTM A537 & -671.5 & -701.9 & -769.1 \\
\hline MPCMS Ag/AgCl & -29.1 & & \\
\hline MPCMS Calomel & & +2.5 & \\
\hline MPCMS Cu/CuSO & & & -40.0 \\
\hline \multicolumn{4}{|l}{-106.4}
\end{tabular}

This page may be reproduced as necessary. of 


$$
\begin{aligned}
& \text { RPP-RPT-44463, Rev. } 0 \\
& \text { RPP-PLAN-43916, Rev. } 0
\end{aligned}
$$

\section{AN-107}

\section{1-AY-101 Simulant}

Electrolyte Contamination

(24.5)

(22.9)

DATE: 217110 TIME: $1: 15 \mathrm{pm}$ TEMP: 24.5 Amount of Contaminant Added (Total): Complete fill w/ waste pH: 10.99 Immersed AAR TC128 Electrode vs. Immersed MPCMS Reference Electrodes

\begin{tabular}{|l|l|l|l|}
\hline & $\begin{array}{l}\text { MPCMS } \\
\text { Ag/AgCl }\end{array}$ & $\begin{array}{l}\text { MPCMS } \\
\text { Calomel }\end{array}$ & $\begin{array}{l}\text { MPCMS } \\
\text { Cu/CuSO }\end{array}$ \\
\hline AAR TC128 & -416.2 & -442.3 & -351.5 \\
\hline
\end{tabular}

Immersed Test Electrodes vs. Room Temperature MPCMS Reference Electrodes

\begin{tabular}{|l|l|l|l|}
\hline & $\begin{array}{l}\text { MPCMS } \\
\text { Ag/AgCl }\end{array}$ & $\begin{array}{l}\text { MPCMS } \\
\text { Calomel }\end{array}$ & $\begin{array}{l}\text { MPCMS } \\
\text { Cu/CuSO }_{4}\end{array}$ \\
\hline AAR TC128 & -406.0 & -448.7 & -521.2 \\
\hline MPCMS Ag/AgCl & +10.0 & & \\
\hline MPCMS Calomel & & -6.7 & \\
\hline MPCMS Cu/CuSO & & & -170.5 \\
\hline
\end{tabular}

\begin{tabular}{|c|c|c|c|}
\hline & $\begin{array}{l}\text { Laboratory } \\
\text { Ag/AgCl }\end{array}$ & $\begin{array}{l}\text { Laboratory } \\
\text { Calomel }\end{array}$ & $\begin{array}{l}\text { Laboratory } \\
\mathrm{Cu} / \mathrm{CuSO}_{4}\end{array}$ \\
\hline AAR TC128 & -418.4 & -447.3 & -515.4 \\
\hline MPCMS Ag/AgCl & -2.0 & & \\
\hline MPCMS Calomel & & -5.4 & \\
\hline $\mathrm{MPCMS} \mathrm{Cu} / \mathrm{CuSO}_{4}$ & & & -164.4 \\
\hline
\end{tabular}

Immersed Test Electrodes vs. Room Temperature Laboratory-Grade Reference Electrodes

This page may be reproduced as necessary.

of 
RPP-RPT-44463, Rev. 0

RPP-PLAN-43916, Rev. 0

\section{1-AY-101 Simulant}

\section{Electrolyte Contamination}

25.6

DATE: 218110 TIME: 08:00 AM TEMP:

24.8

Amount of Contaminant Added (Total): filled $\omega /$ waste pH: 11.78

Immersed AAR TC128 Electrode vs. Immersed MPCMS Reference Electrodes

\begin{tabular}{|l|l|l|l|}
\hline & $\begin{array}{l}\text { MPCMS } \\
\text { Ag/AgCl }\end{array}$ & $\begin{array}{l}\text { MPCMS } \\
\text { Calomel }\end{array}$ & $\begin{array}{l}\text { MPCMS } \\
\text { Cu/CuSO }_{4}\end{array}$ \\
\hline AAR TC128 & -227.2 & -261.3 & -252.5 \\
\hline
\end{tabular}

Immersed Test Electrodes vs. Room Temperature MPCMS Reference Electrodes

\begin{tabular}{|c|c|c|c|}
\hline & $\begin{array}{l}\text { MPCMS } \\
\text { Ag/AgCl }\end{array}$ & $\begin{array}{l}\text { MPCMS } \\
\text { Calomel }\end{array}$ & $\begin{array}{l}\text { MPCMS } \\
\mathrm{Cu} / \mathrm{CuSO}_{4}\end{array}$ \\
\hline AAR TC128 & -208.4 & -250.7 & -322.9 \\
\hline MPCMS Ag/AgCl & 16.0 & & \\
\hline MPCMS Calomel & & 8.1 & \\
\hline MPCMS Cu/CuSO 4 & & & -73.1 \\
\hline
\end{tabular}

Immersed Test Electrodes vs. Room Temperature Laboratory-Grade Reference Electrodes

\begin{tabular}{|c|c|c|c|}
\hline & $\begin{array}{l}\text { Laboratory } \\
\mathrm{Ag} / \mathrm{AgCl}\end{array}$ & $\begin{array}{l}\text { Laboratory } \\
\text { Calomel }\end{array}$ & $\begin{array}{l}\text { Laboratory } \\
\mathrm{Cu} / \mathrm{CuSO}_{4}\end{array}$ \\
\hline AAR TC128 & -224.3 & -250.1 & -314.3 \\
\hline MPCMS Ag/AgCl & $1.9 \mathrm{mv}$ & & \\
\hline MPCMS Calomel & & $9.4 \mathrm{mv}$ & \\
\hline${\mathrm{MPCMS} \mathrm{Cu} / \mathrm{CuSO}_{4}}_{4}$ & & & -62.4 \\
\hline
\end{tabular}

This page may be reproduced as necessary.

Page

of 


$$
\begin{aligned}
& \text { RPP-RPT-44463, Rev. } 0 \\
& \text { RPP-PLAN-43916, Rev. } 0
\end{aligned}
$$

\section{1-AN-107 Simulant}

\section{Electrolyte Contamination}

$$
25.6
$$

DATE: $\left.218\right|_{10}$ TIME: 08:15 AN TEMP: 24.8 10.62

Amount of Contaminant Added (Total): electrodes full of waste simulaht

Immersed ASTM A537 Electrode vs. Immersed MPCMS Reference E
\begin{tabular}{|l|c|c|c|}
\hline & $\begin{array}{c}\text { MPCMS } \\
\text { Ag/AgCl }\end{array}$ & $\begin{array}{c}\text { MPCMS } \\
\text { Calomel }\end{array}$ & $\begin{array}{c}\text { MPCMS } \\
\text { Cu/CuSO }\end{array}$ \\
\hline ASTM A537 & -389.2 & -412.9 & -309.5 \\
\hline
\end{tabular}

Immersed Test Electrodes vs. Room Temperature MPCMS Reference Electrodes

\begin{tabular}{|l|l|l|l|}
\hline & $\begin{array}{c}\text { MPCMS } \\
\text { Ag/AgCl }\end{array}$ & $\begin{array}{c}\text { MPCMS } \\
\text { Calomel }\end{array}$ & $\begin{array}{c}\text { MPCMS } \\
\text { Cu/CuSO }\end{array}$ \\
\hline ASTM A537 & -374.6 & -416.8 & -488.7 \\
\hline MPCMS Ag/AgCl & 14.4 & & \\
\hline MPCMS Calomel & & -4.9 & \\
\hline MPCMS Cu/CuSO & & & -180.8 \\
\hline
\end{tabular}

Immersed Test Electrodes vs. Room Temperature Laboratory-Grade Reference Electrodes

\begin{tabular}{|l|c|c|c|}
\hline & $\begin{array}{c}\text { Laboratory } \\
\text { Ag/AgCl }\end{array}$ & $\begin{array}{c}\text { Laboratory } \\
\text { Calomel }\end{array}$ & $\begin{array}{c}\text { Laboratory } \\
\text { Cu/CuSO }\end{array}$ \\
\hline ASTM A537 & -389.7 & -415.5 & -478.6 \\
\hline MPCMS Ag/AgCl & 0.48 & & \\
\hline MPCMS Calomel & & -3.6 & \\
\hline MPCMS Cu/CuSO & & & -169.9 \\
\hline
\end{tabular}

This page may be reproduced as necessary.

Page of 
RPP-RPT-44463, Rev. 0

\section{APPENDIX D}

\section{TEST EXCEPTIONS}


RPP-RPT-44463, Rev. 0

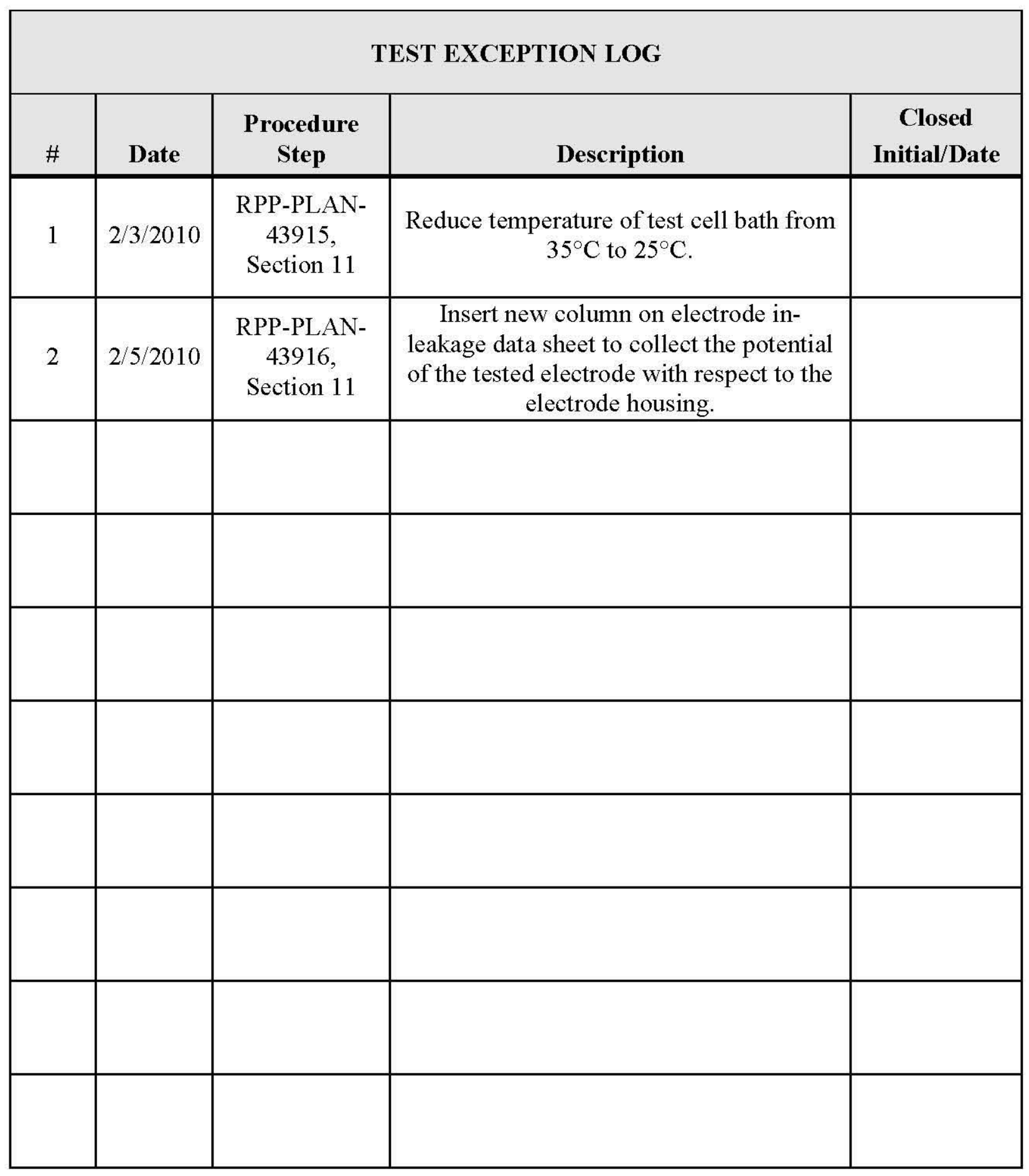




\section{TEST EXCEPTION DISPOSITION}

Test Exception Number: 1

\section{Describe Corrective Action:}

In RPP-PLAN-43915, Section 11, "Test Instructions," all instances that stipulate that $35^{\circ} \mathrm{C}$ will be used as the test cell temperature bath have been changed to $25^{\circ} \mathrm{C}$. Maintaining a temperature of $25^{\circ} \mathrm{C}$ was achievable using the PolyScience ${ }^{\mathrm{TM}^{3}}$ Model 7306 temperature controller and copper cooling coils. It was thought prior to testing that a temperature of $25^{\circ} \mathrm{C}$ would be unfeasible due to a competition between the laboratory's HVAC system and the temperature controller. However, the use of both copper cooling coils and the temperature controller were able to maintain a constant temperature of $25^{\circ} \mathrm{C}$ for the test bath.

\section{Corrective Action Completed:}




\section{TEST EXCEPTION DISPOSITION}

Test Exception Number:

\section{Describe Corrective Action:}

In order to verify that leakage resistance is present when the backs of the electrodes are wetted with contaminate, a test was added to collect the potential formed between the electrode and the electrode housing. RPP-PLAN-43915, Section 11, "Test Instructions," does not specify that this measurement should be made. A fifth column named Electrode Housing was added to the table, "Immersed Test Electrodes vs. Room Temperature MPCMS Reference Electrodes," to capture the data.

Corrective Action Completed:

Test Director: Date: 
RPP-RPT-44463, Rev. 0

\section{APPENDIX E}

\section{SUPPLEMENTARY DATA}

E-1 

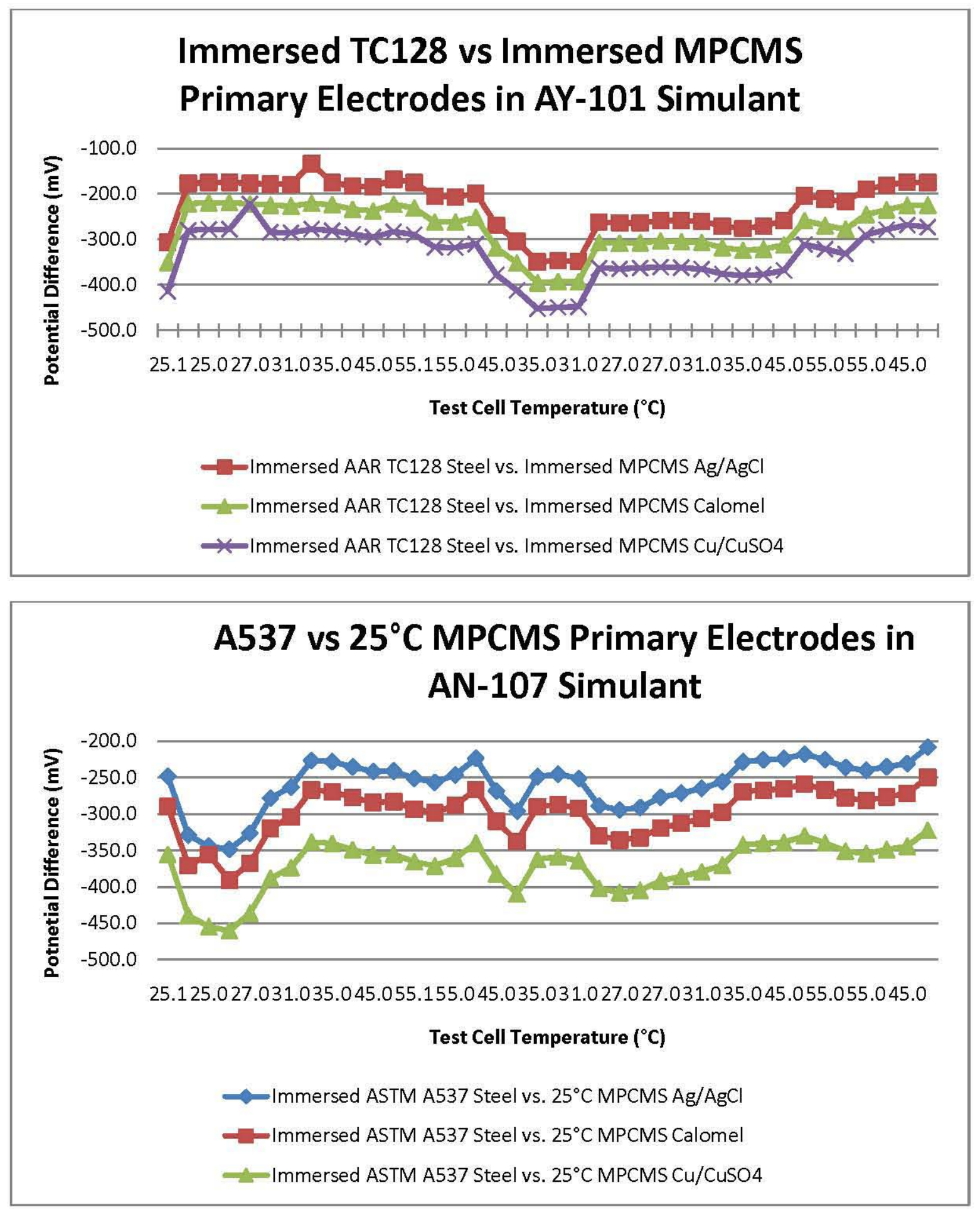

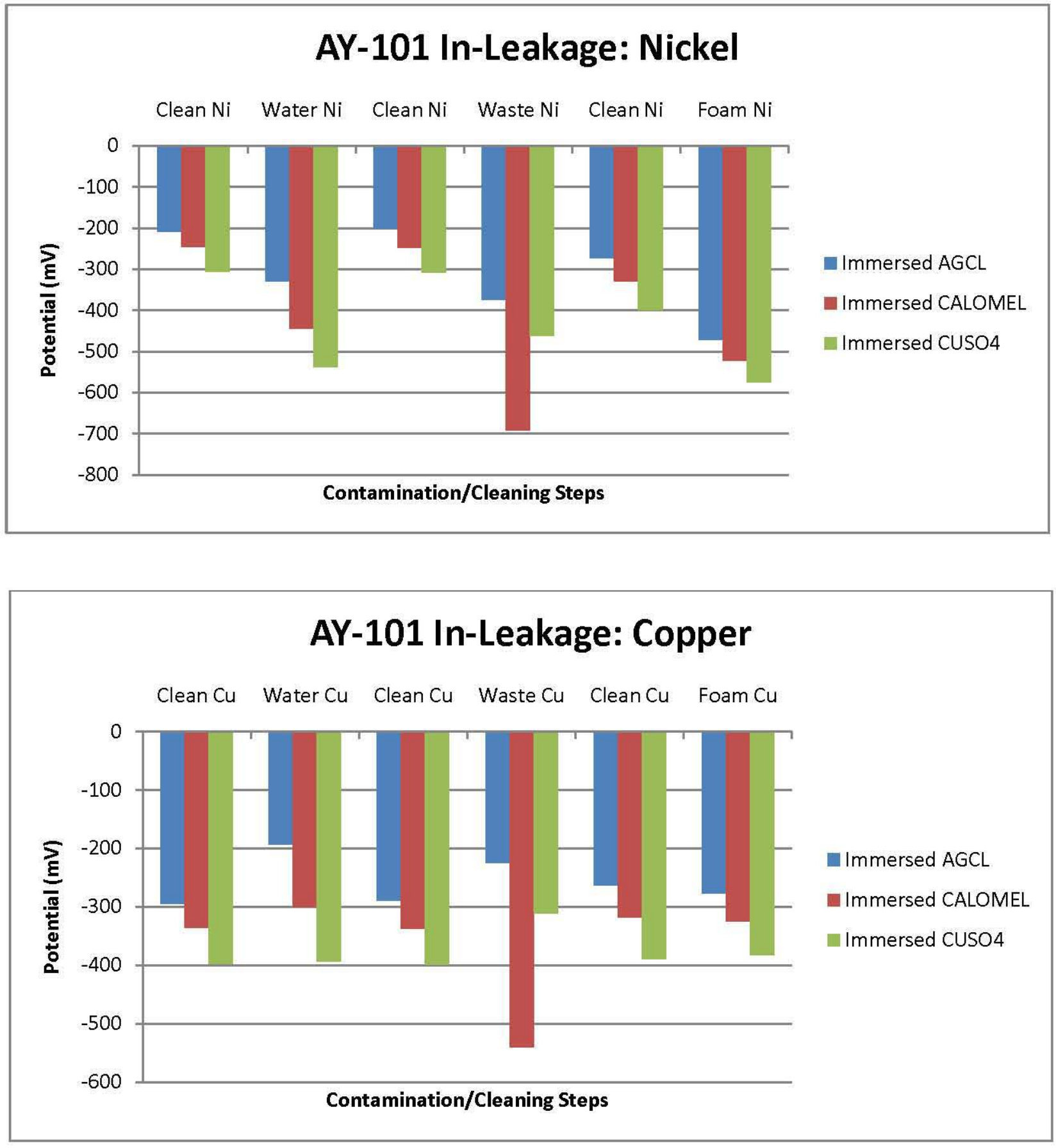
RPP-RPT-44463, Rev. 0
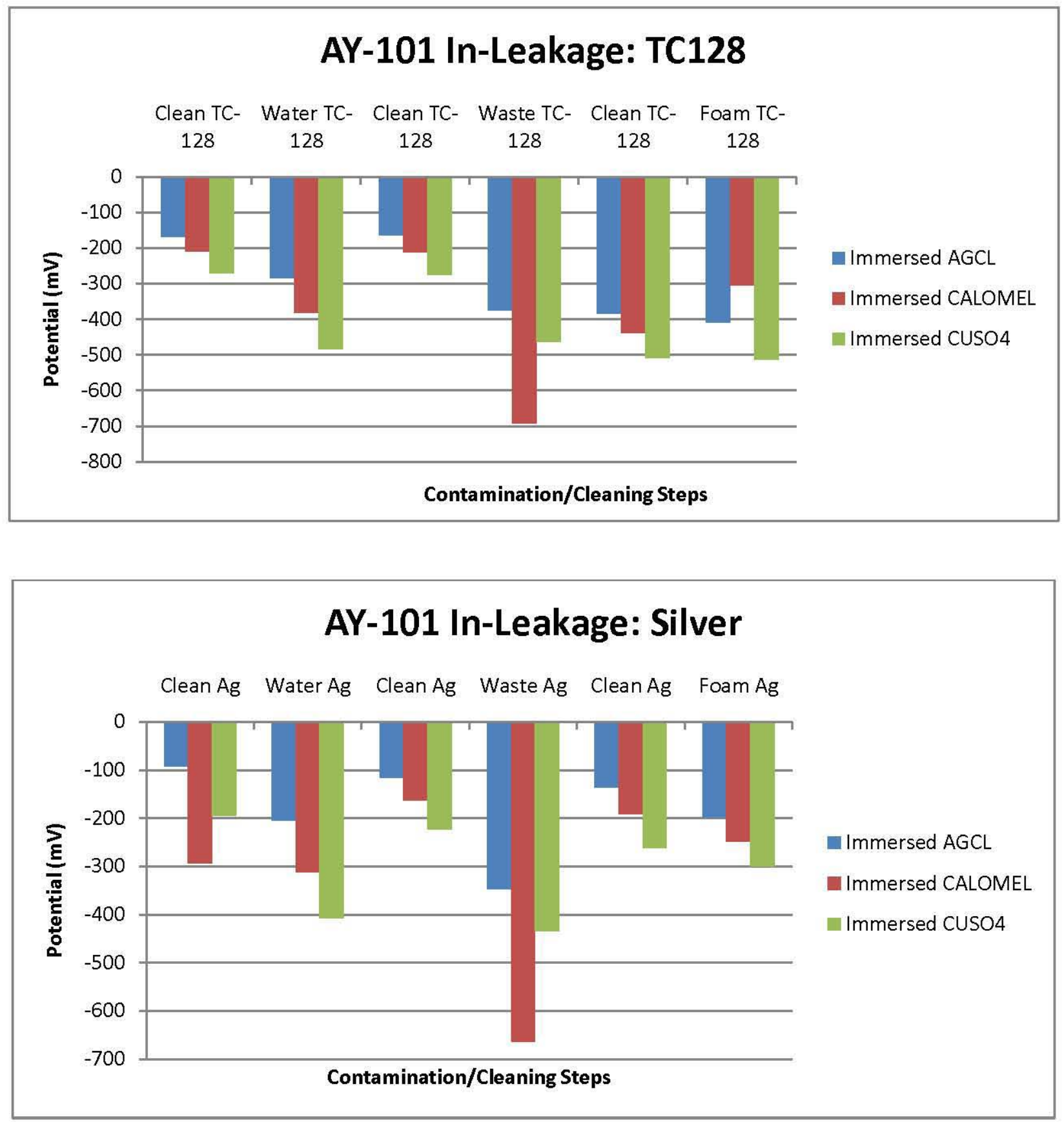

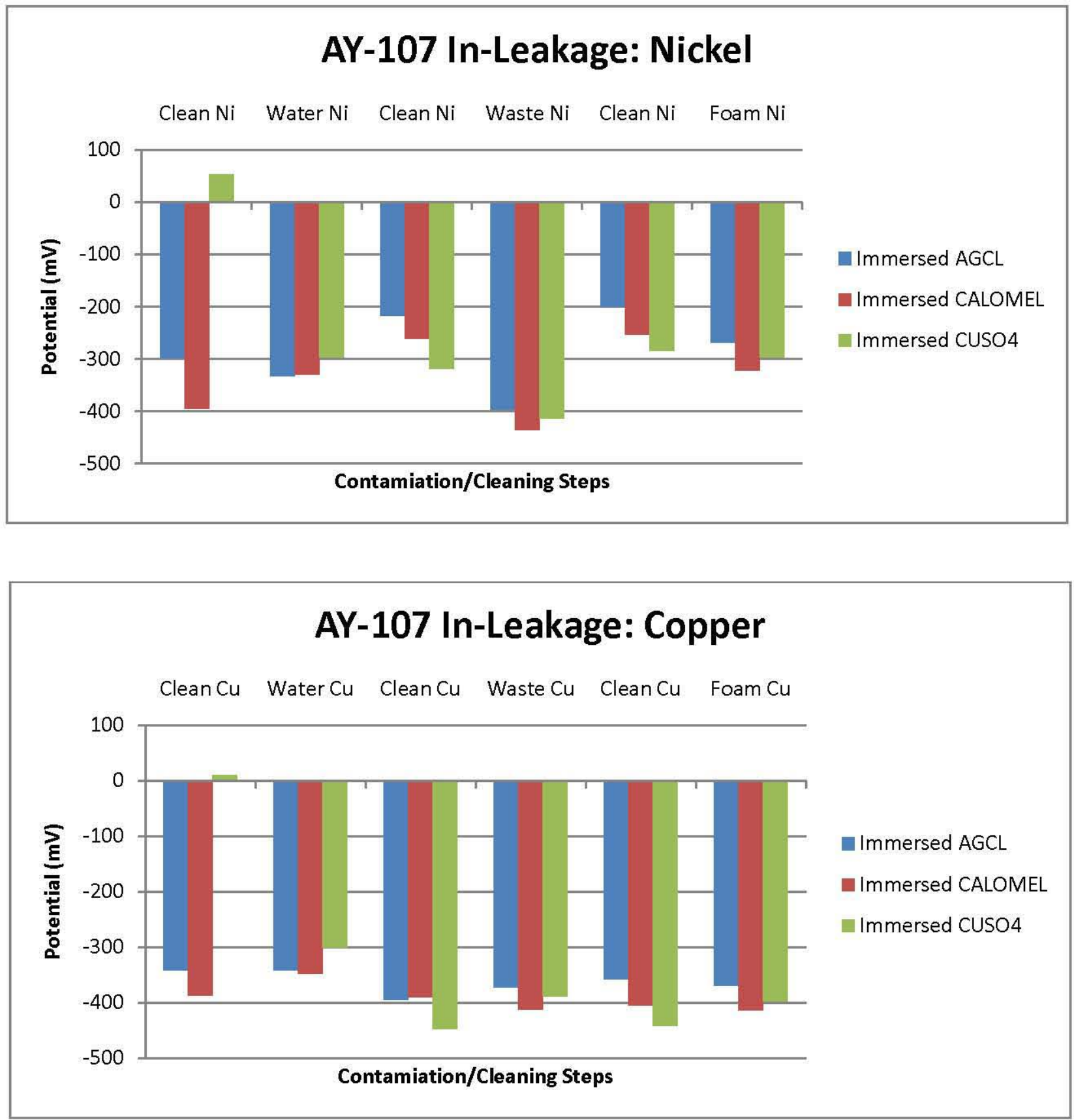

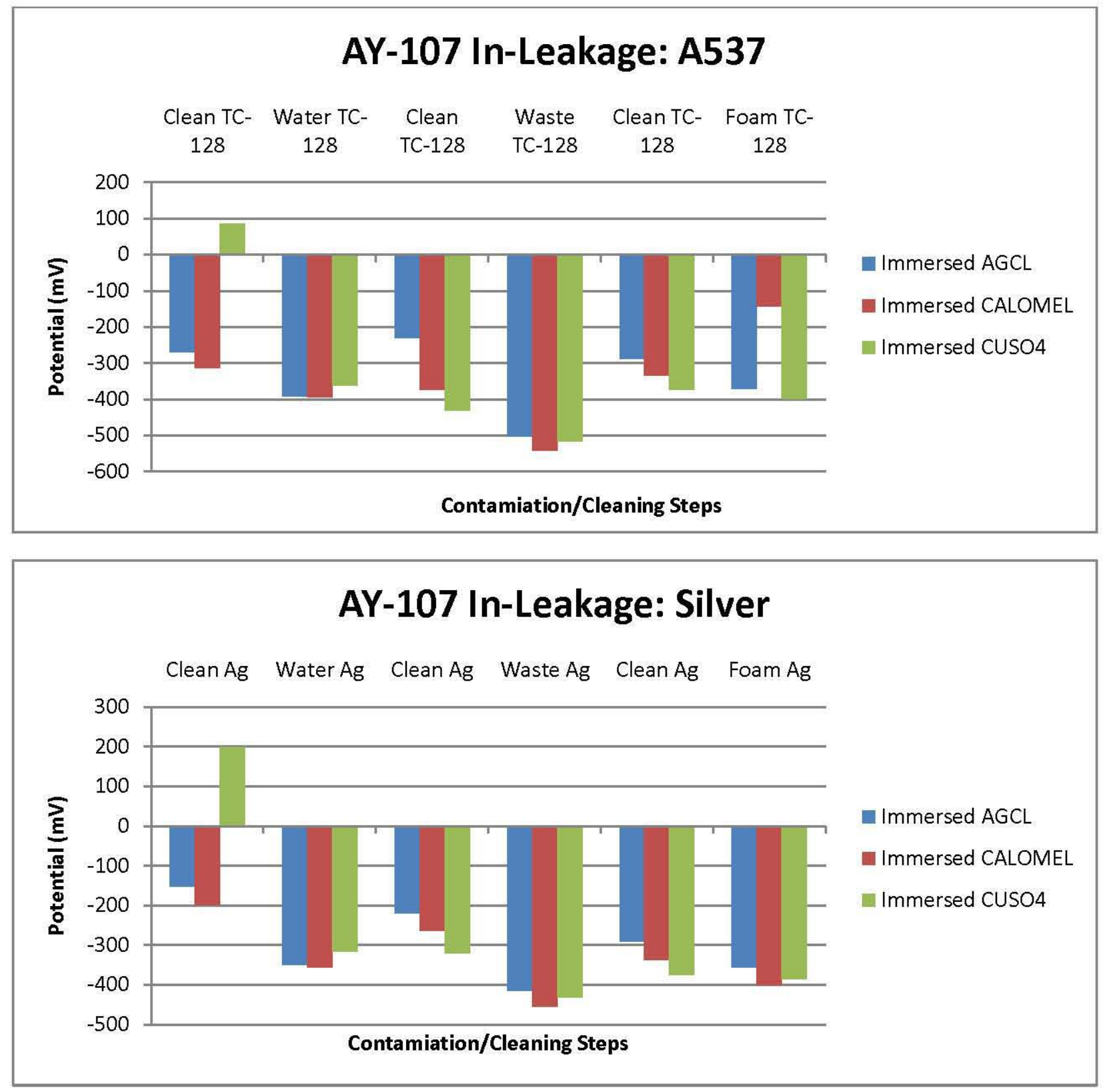

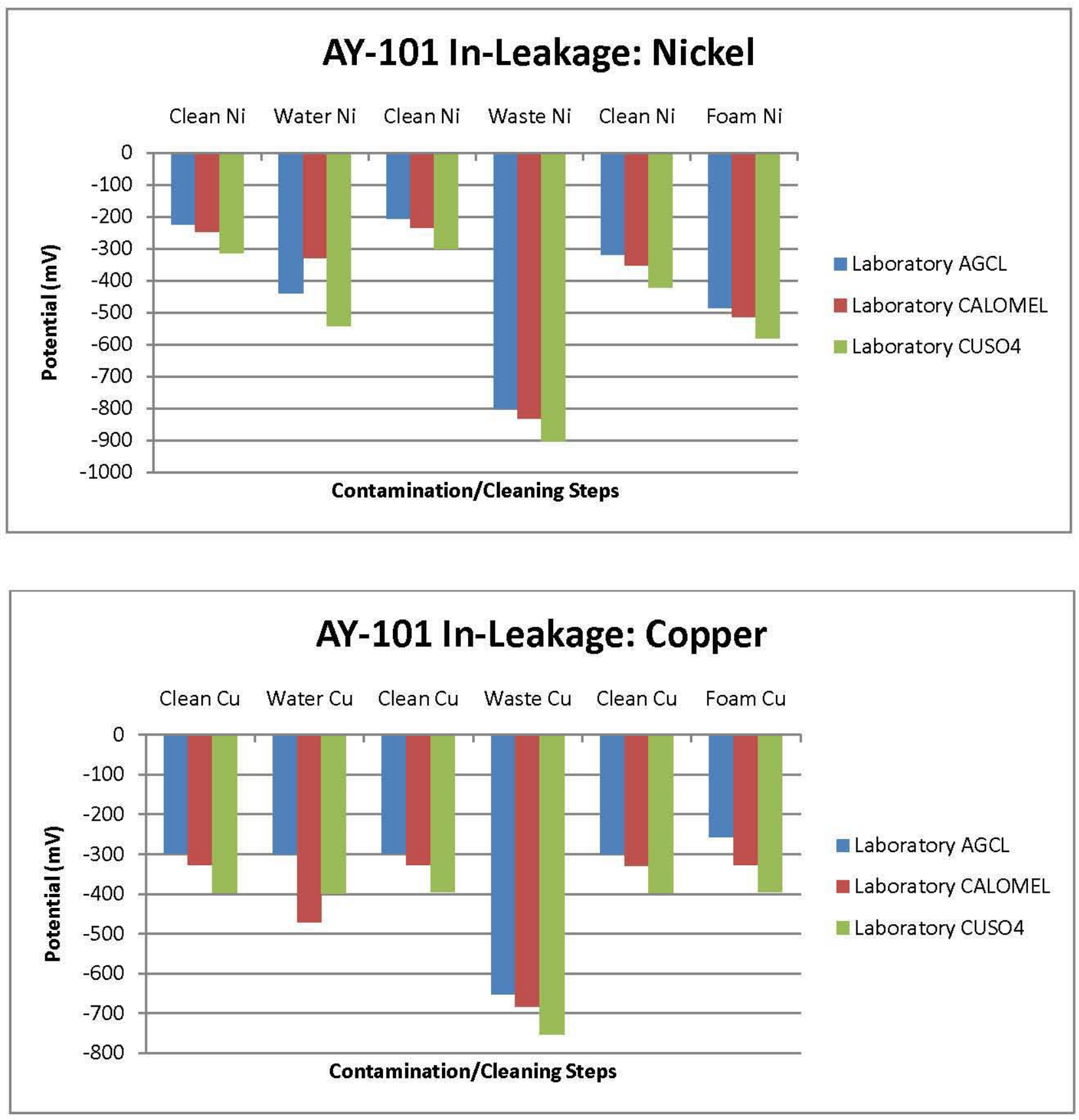

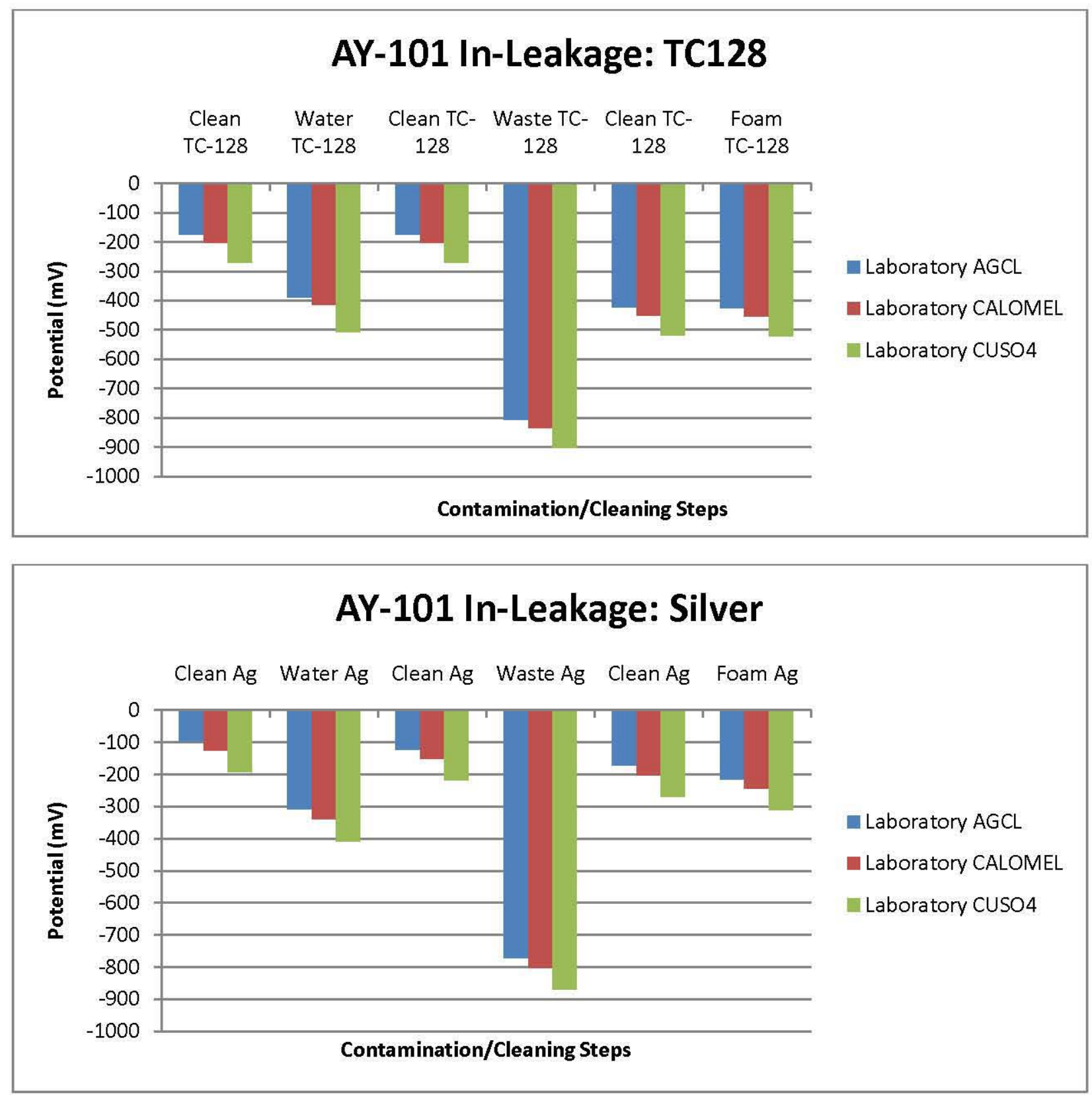

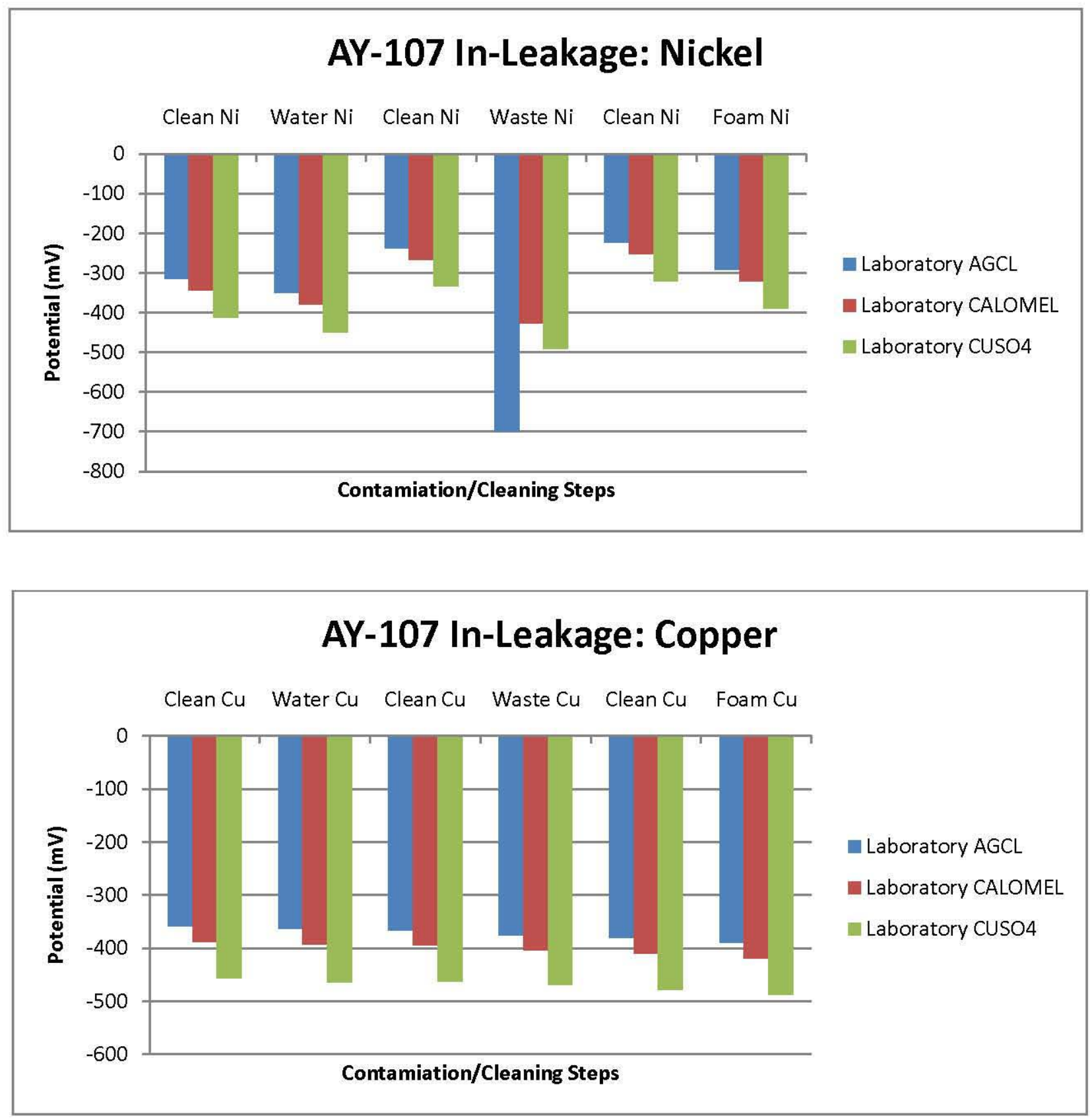
RPP-RPT-44463, Rev. 0

\section{AY-107 In-Leakage: A537}

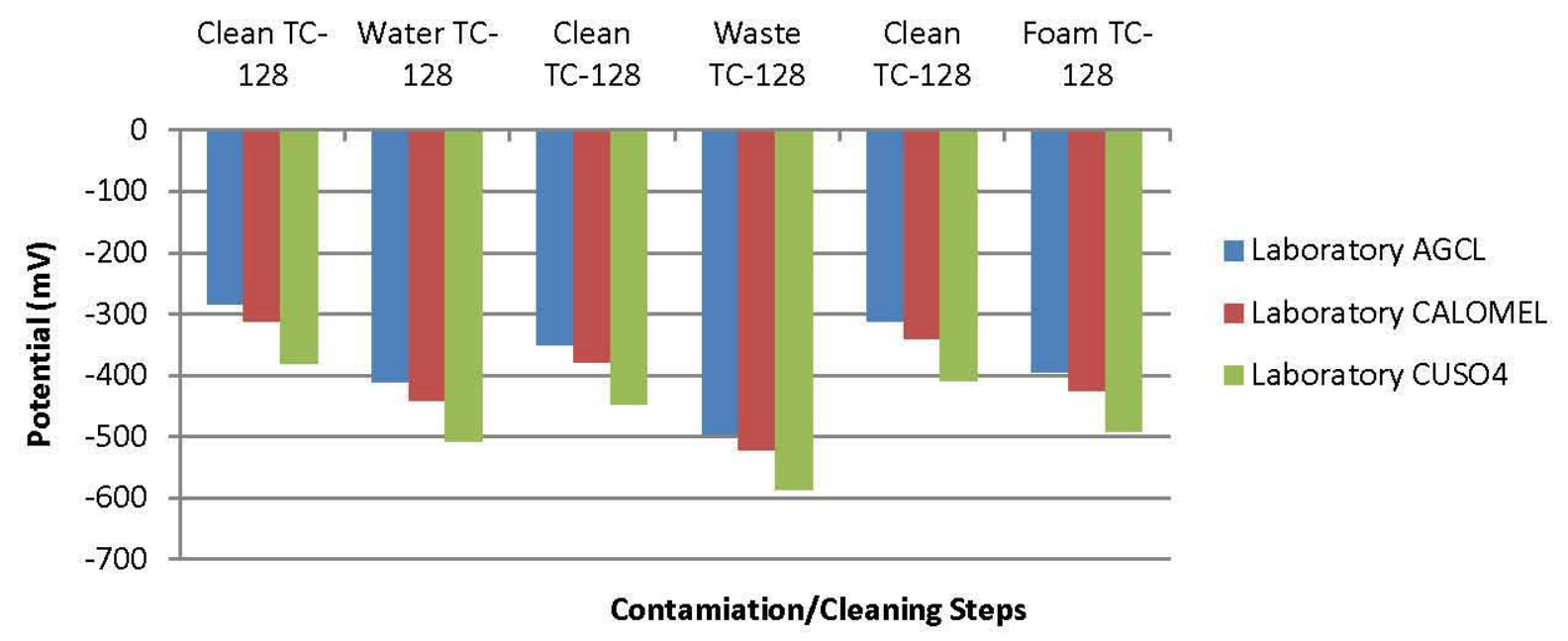


RPP-RPT-44463, Rev. 0
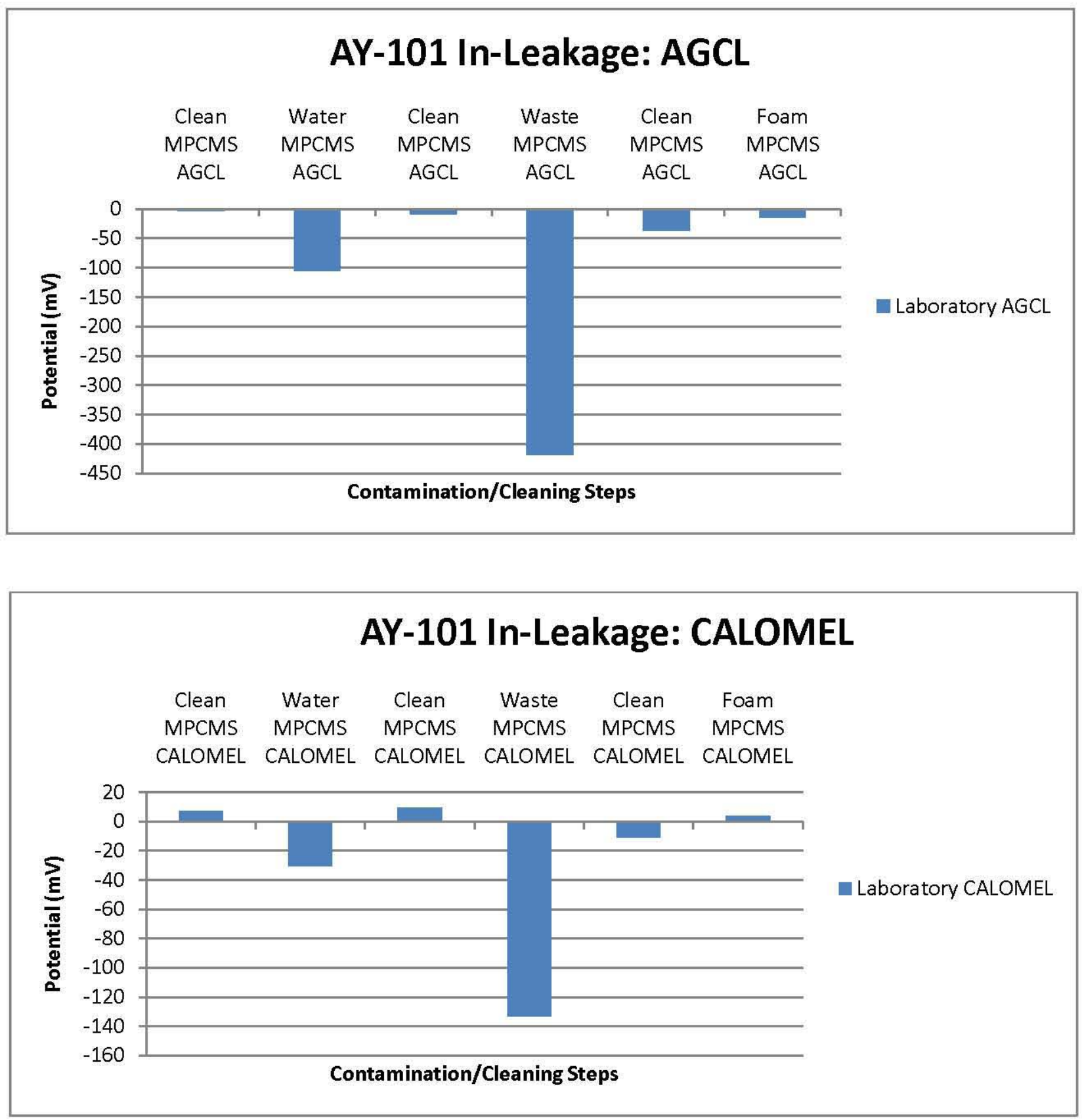
RPP-RPT-44463, Rev. 0

\section{AY-101 In-Leakage: CUSO4}

$\begin{array}{cccccc}\text { Clean } & \text { Water } & \text { Clean } & \text { Waste } & \text { Clean } & \text { Foam } \\ \text { MCPMS } & \text { MCPMS } & \text { MCPMS } & \text { MCPMS } & \text { MCPMS } & \text { MCPMS } \\ \text { CUSO4 } & \text { CUSO4 } & \text { CUSO4 } & \text { CUSO4 } & \text { CUSO4 } & \text { CUSO4 }\end{array}$

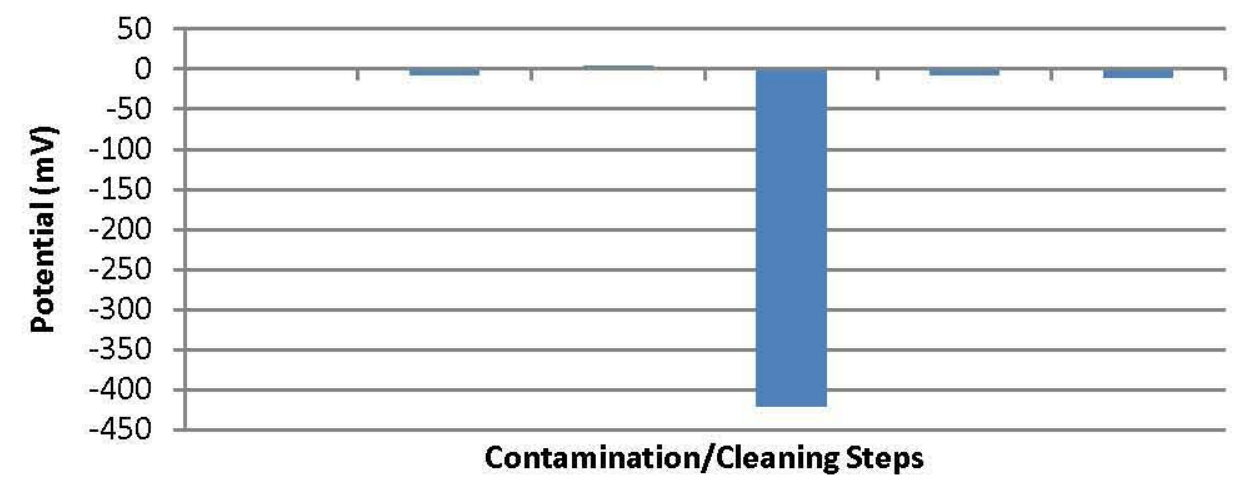

- Laboratory CUSO4 

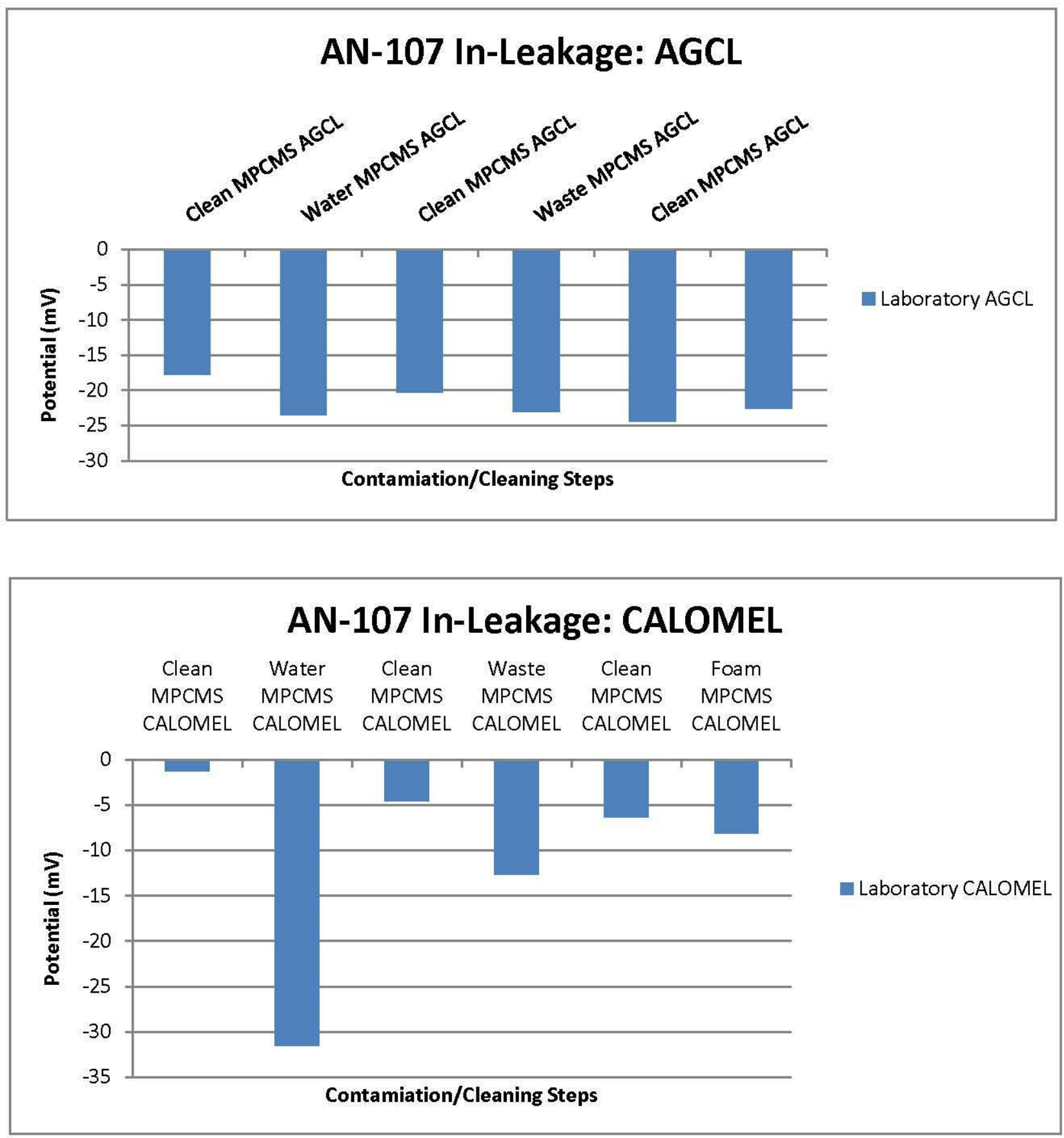
RPP-RPT-44463, Rev. 0

\section{AN-107 In-Leakage: CUSO4}

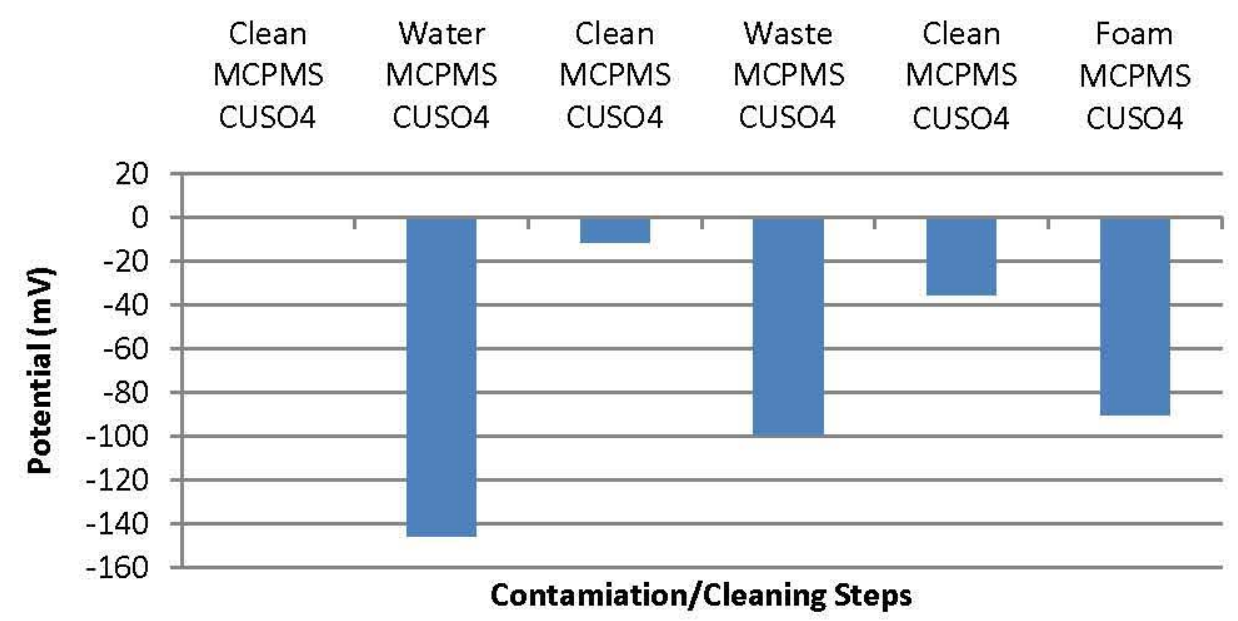

Laboratory CUSO4 